UC-814

Issued: October 1993

Geologic Evaluation of Six Nonwelded Tuff Sites

in the Vicinity of Yucca Mountain, Nevada

for a Surface-Based Test Facility for the

Yucca Mountain Project

D. E. Broxton

S. J. Chipera

F. M. Byers, Jr.

C. A. Rautman* 


\title{
GEOLOGIC EVALUATION OF SIX NONWELDED TUFF SITES IN THE VICINITY OF YUCCA MOUNTAIN, NEVADA FOR A SURFACE-BASED TEST FACILITY FOR THE YUCCA MOUNTAIN PROJECT
}

\author{
by \\ D. E. Broxton, S. J. Chipera, F. M. Byers, Jr., \\ and C. A. Rautman
}

\begin{abstract}
Outcrops of nonwelded tuff at six locations in the vicinity of Yucca Mountain, Nevada, were examined to determine their suitability for hosting a surface-based test facility for the Yucca Mountain Project. Investigators will use this facility to test equipment and procedures for the Exploratory Studies Facility and to conduct site characterization field experiments. The outcrops investigated contain rocks that Include or are similar to the tuffaceous beds of Calico Hills, an important geologic and hydrologic barrier between the potential repository and the water table. The tuffaceous beds of Calico Hills at the site of the potential repository consist of both vitric and zeolitic tuffs, thus three of the outcrops examined are vitric tuffs and three are zeolitic tuffs. New data were collected to determine the lithology, chemistry, mineralogy, and modal petrography of the outcrops. Some preliminary data on hydrologic properties are also presented. Evaluation of suitability of the six sites is based on a comparison of their geologic characteristics to those found in the tuffaceous beds of Calico Hills within the exploration block.

Vitric tuffs at Busted Butte are excellent analogs to the geologic conditions in the vitric Calico Hills unit within the exploration block. Bedded vitrlc tuffs at Busted Butte include, in ascending order, the nonwelded top of the Prow Pass Member, the Wahmonie Formation, the tuffaceous beds of Calico Hills, and the nonwelded base of the Topopah Spring Member. A second site, in the northeastern part of Yucca Mountain, also has characteristics suitable for a surface-based test facility in vitric tuffs. Rocks at this site include the nonwelded top of the Pah Canyon Member and overlying bedded tuffs. A third site, in tuffs of the Prow Pass Member $5 \mathrm{~km}$ southwest of Busted Butte, is unsultable for surface-based testing.

Zeolitic tuffs cropping out at Prow Pass are good analogs to the zeolitic tuffaceous beds of Calico Hills within the exploration block. Except for minor differences in mineralogy and chemistry, these zeolitic tuffs, which include the tuffaceous beds of Calico Hills and the nonwelded base of the Topopah Spring Member, are similar to the zeolitic tuffs within the exploration block. A second site in the northeastern part of Yucca Mountain is also a suitable location for a surface-based test facllity in zeolitic tuffs. Rocks at this site include the nonwelded base of the Pah Canyon Member and underlying bedded tuffs. A third site at Calico Hills is unsuitable for surface-based testing.

Outcrops of nonwelded tuff at Yucca Mountain provide suitable host rocks for a surface-based test facility. The recommended host rocks for a such a facillty are vitric tuffs at Busted Butte and/or zeolitic tuffs at Prow Pass. Additional site screening can take place when data for hydrologic properties become available for all of the sites investigated in this study.
\end{abstract}




\section{Contents}

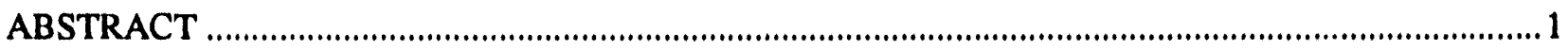

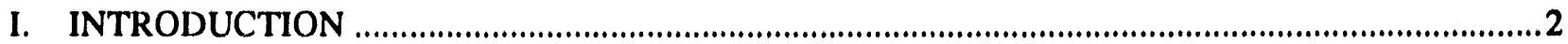

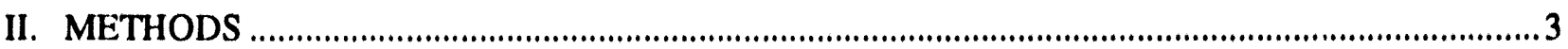

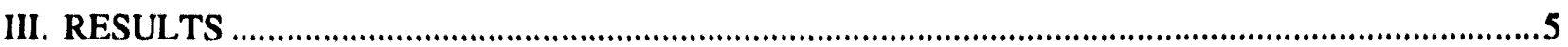

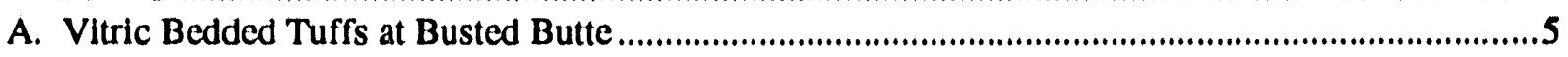

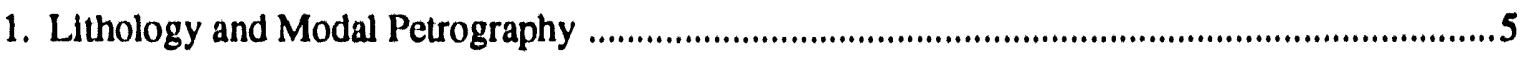

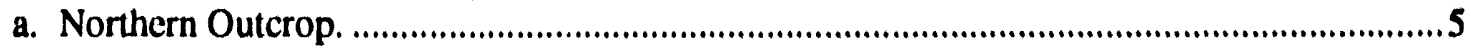

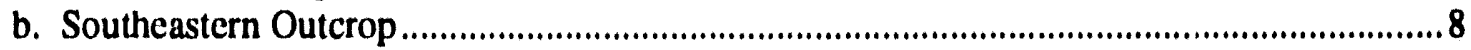

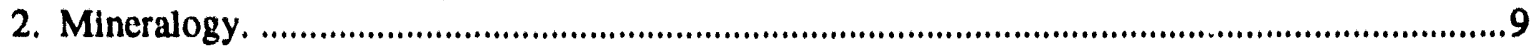

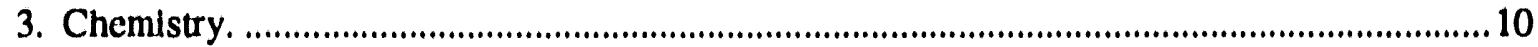

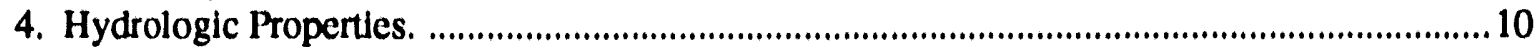

B. Vitric and Zeolitic Bedded Tuffs, NE Side of Yucca Mt.......................................................... 10

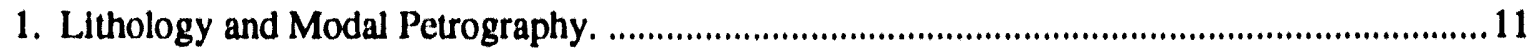

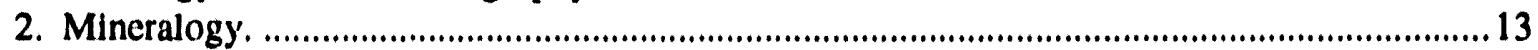

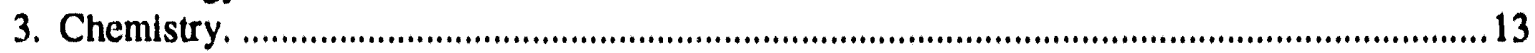

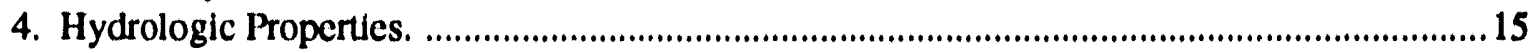

C. Vitric Ash-Flow Tuffs, South of Stagecoach Road ............................................................ 17

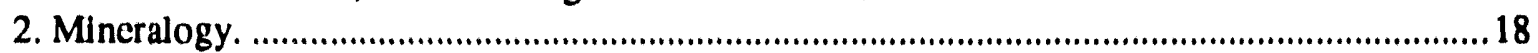

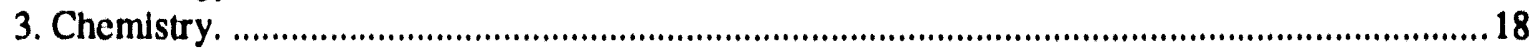

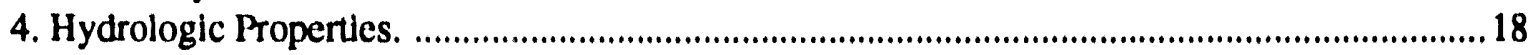

D. Zcolitic Tuffaceous Beds of Calico Hills at Prow Pass ............................................................... 18

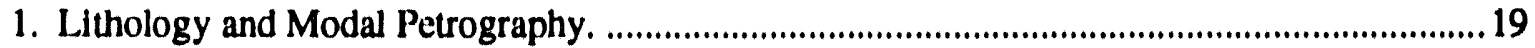

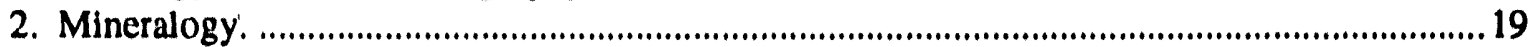

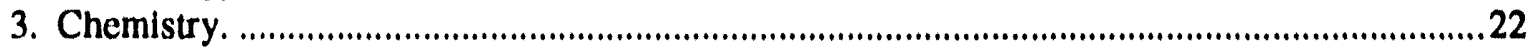

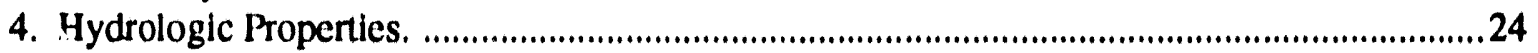

E. Zeoilitc Tuffaceous Beds of Calico Hills at Calico Hills ..........................................................25

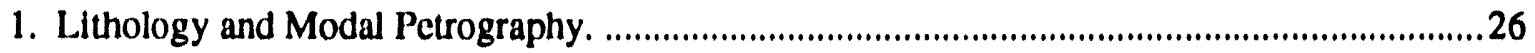

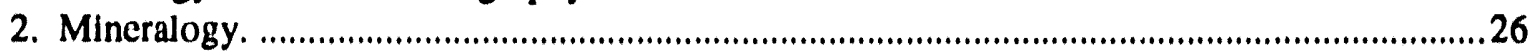

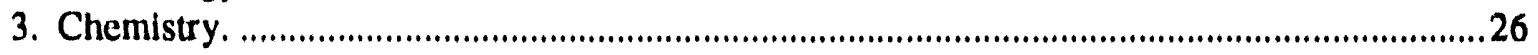

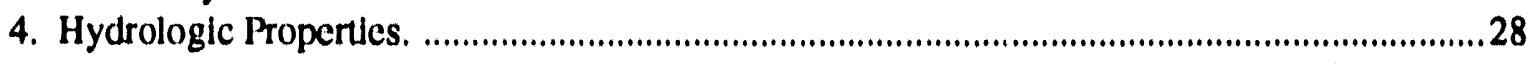

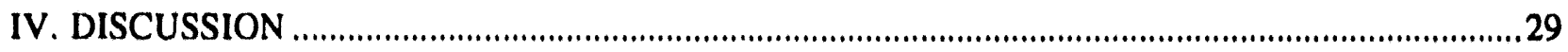

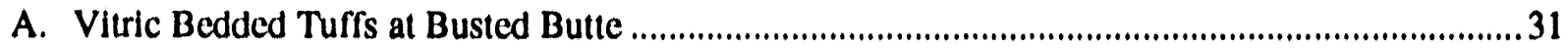

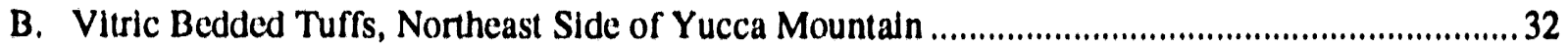

C. Vitric Ash-Flow Tuffs, South of Stggecoach Road ............................................................... 33

D. Zeolitic Tuffaceous Beds of Crilico Hills at Prow Pass ............................................................... 34

E. Zeolitic Tuffaceous Beds of Calico Hills at Calico Hills ........................................................... 34

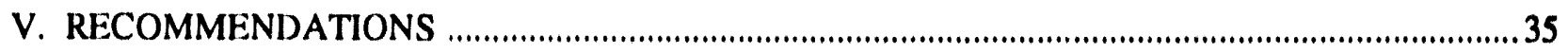

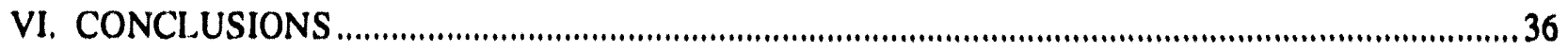

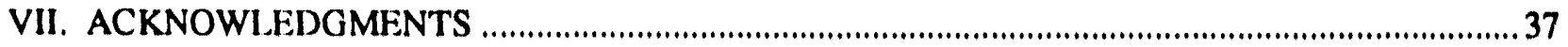


APPENDIX A. PETROGRAPHIC MODAL ANALYSES OF NONWELDED TUFFS

FROM OUTCROP, YUCCA MOUNTAIN, NEVADA

APPENDIX B. X-RAY DIFFRACTION ANAL YSES OF NONWELDED TUFFS FROM OUTCROP, YUCCA MOUNTAIN, NEVADA

APPENDIX C. MAJOR- AND TRACE-ELEMENT ANALYSES OF NONWELDED

TUFFS FROM OUTCROP, YUCCA MOUNTAIN, NEVADA

APPENDIX D. SAMPLE KEY AND LOCATIONS FOR VITRIC AND ZEOLITIC TUFFS INVESTIGATED FOR A SURFACE-BASED TEST FACILITY, YUCCA MOUNTAIN, NEVADA

APPENDIX E. DATA SOURCES. .80 


\section{List of Figures}

Figure 1. Locations of outcrops of nonwelded vitric and zeolitic tuffs investigated for a

potential surface-based test facility in the vicinity of Yucca Mountain

Figure 2. Location of vitric bedded tuffs sampled at Busted Butte

Figure 3. Stratigraphic section showing sample locations within vitric bedded tuffs

at the north end of Busted Butte

Figure 4. Variation diagrams summarizing petrographic, mineralogic, and chemical characteristics of vitric bedded tuffs at the north end of Busted Butte

Figure 5. Stratigraphic section and sample locations within vitric bedded tuffs on the southeast side of Busted Butte

Figure 6. Location of composite section of vitric tuffs and zeolitic tuffs sampled at northeastern Yucca Mountain

Figure 7. Composite stratigraphic section and sample locations for vitric tuffs and zeolltic tuffs at northeastern Yucca Mountain

Figure 8. Variations diagrams summarizing petrographic, mineralogic, and chemical characteristics of vitric tuffs and zeolitic tuffs at the northeastern Yucca Mountain

Figure 9. Stacked histograms of porosity, bulk density, and particle density for vitric and zeolitic tuffs at the northeastern Yucca Mountain

Figure 10. Location of vitric ash-flow tuffs sampled at outcrops $5 \mathrm{~km} \mathrm{SW}$ of Busted Butte, in the vicinity of Stagecoach Road

Figure 11. Location of zeolitic tuffs sampled at outcrops in the vicinity of Prow Pass

Figure 12. Stratigraphic section and sample locations for zeolitic tuffs in the southern part of the Prow Pass area

Figure 13. Stratigraphic section and sample locations for zeolitic tuffs in the central part of the Prow Pass area.

Figure 14. Variation diagrams summarizing petrographic, mineralogic, and chemical characteristics of zeolitic tuffs sampled in the stratigraphic section at the southern end of the Prow Pass area.

Figure 15. Compositional variations along the lateral traverse within the tuffaceous beds of Calico Hills in the Prow Pass area

Figure 16. Histograms of porosity, bulk density, and particle density for zeolitic tuffaceous beds of Calico Hills sampled in a vertical stratigraphic section at the southern end of the Prow Pass area

Figure 17. Location of zeolitic tuffs sampled in a lateral traverse in the southwestern part of Calico Hills

Figure 18. Histograms comparing the mineralogy of zeolitic tuffaceous beds of Calico Hills within the exploration block at Yucca Mountain to zeolitic tuffs of the same unit at Prow Pass and Calico Hills

Figure 19. Histograms comparing the chemistry of the zeolitic tuffaceous beds of Calico Hills within the exploration block at Yucca Mountain to the same unit at Prow Pass and Calico Hills

Figure 20. Histograms of porosity and bulk density for zeolitic tuffaccous beds of Calico Hills sampled in a lateral traverse at Calico Hills

Figure 21. Histograms of porosity, bulk density, and particle density for vitric tuffaceous beds of Calico Hills in the exploration block and for zeolitic tuffs of the same unit in the exploration block 


\section{List of Tables}

Table I. Hydrologic properties of the Pah Canyon Member and bedded tuffs on the northeast side of Yucca Mountain, Nevada

Table II. Hydrologic properties of the zeolitic tuffaceous beds of Callco Hills and Topopah Spring Member at Prow Pass, Yucca Mountain, Nevada

Table III. Hydrologic properties of the zeolitic tuffaceous beds of Calico Hills at Calico Hills, Yucca Mountain, Nevada.

Table IV. Hydrologic propertles of the tuffaceous beds of Calico Hills in the vicinity of the potential repository, Yucca Mountain, Nevada

Table V. Ranking of vitric and zeolitic tuff sites to host a surface-based test facility, Yucca 


\title{
GEOLOGIC EVALUATION OF SIX NONWELDED TUFF SITES IN THE VICINITY OF YUCCA MOUNTAIN, NEVADA FOR A SURFACE-BASED TEST FACILITY FOR THE YUCCA MOUNTAIN PROJECT
}

\author{
by \\ D. E. Broxton, S. J. Chlpera, F. M. Byers, Jr., \\ and C. A. Rautman
}

\begin{abstract}
Outcrops of nonwelded tuff at six locations in the vicinity of Yucca Mountain, Nevada, were examined to determine their suitability for hosting a surface-based test facillty for the Yucca Mountain Project. Investigators will use this facility to test equipment and procedures for the Exploratory Studies Facility and to conduct site characterization fleld experiments. The outcrops investigated contain rocks that include or are similar to the tuffaceous beds of Calico Hills, an Important geologic and hydrologic barrier between the potentlal repository and the water table. The tuffaceous beds of Calico Hills at the site of the potential repository consist of both vitric and zeolitic tuffs, thus three of the outcrops examined are vitric tuffs and three are zeolitic tuffs. New data were collected to determine the lithology, chemistry, mineralogy, and modal petrography of the outcrops. Some preliminary data on hydrologic properties are also presented. Evaluation of suitability of the six sites is based on a comparison of their geologic characteristics to those found in the tuffaceous beds of Calico Hills within the exploration block.

Vitric tuffs at Busted Butte are excellent analogs to the geologic conditions in the vitric Calico Hills unit within the exploration block. Bedded vitric tuffs at Busted Butte include, in ascending order, the nonwelded top of the Prow Pass Member, the Wahmonie Formation, the tuffaceous beds of Calico Hills, and the nonwelded base of the Topopah Spring Member. A second site, in the northeastern part of Yucca Mountain, also has characteristics suitable for a surface-based test facility in vitric tuffs. Rocks at this site include the nonwelded top of the Pah Canyon Member and overlying bedded tuffs. A third site, in tuffs of the Prow Pass Member $5 \mathrm{~km}$ southwest of Busted Butte, is unsultable for surface-based testing.

Zeolitic tuffs cropping out at Prow Pass are good analogs to the zeolitic tuffaceous beds of Calico Hills within the exploration block. Except for minor differences in mineralogy and chemistry, these zeolitic tuffs, which include the tuffaceous beds of Callco Hills and the nonwelded base of the Topopah Spring Member, are similar to the zeolitic tuffs within the exploration block. A second site in the northeastern part of Yucca Mountain is also a sultable location for a surface-based test facility in zeolitic tuffs. Rocks at this site Include the nonwelded base of the Pah Canyon Member and underlying bedded tuffs. A third site at Callco Hills is unsuitable for surface-based testing.

Outcrops of nonwelded tuff at Yucca Mountain provide sultable host rocks for a surface-based test facility. The recommended host rocks for a such a facillty are vituic tuffs at Busted Butte and/or zeolltic tuffs at Prow Pass. Addltional site screening can take place when data for hydrologic propertles become available for all of the sites investigated in this study.
\end{abstract}




\section{INTRODUCTION}

Outcrops of nonwelded vitric and zeolitic tuffs at six sites in the vicinity of Yucca Mountain were examined as possible locations for a surface-based test facility for the Yucca Mountain Project. The purpose of a surface-based test facllity is to examine testing and construction methodologies for the underground Exploratory Studies Facility (ESF) at Yucca Mountain and to provide a sultable testing environment for scientific experiments in rocks that are similar to key components of the radionuclide barrier beneath the potential repository.

The surface-based test facility should be sited in rocks that are similar to the repository host rock or to key components of the natural geologic barrier system between the repository and the water table. At the time the surface-based test facillty was first proposed in 1988, the ESF (then called the Exploratory Shaft Facility) was designed to penetrate geologic units to the depth of the potentlal repository horizon in the lower part of the Topopah Spring Member of the Paintbrush Tuff. Because extensive testing and site characterization were planned for the repository horizon but not for underlying units, this study emphasizes situng a surface-based test facility in a geologic setting similar to the tuffaceous beds of Calico HIIls, an important geologic and hydrologic barrier between the repository and the water table.

The tuffaceous beds of Calico Hills within the exploration block are made up of two dissimilar lithologles that grade laterally into one another. In the eastern part of the exploration block these tuffs are thoroughly altered to zeolites and have distinct mineralogic, chemical, and hydrologic properties when compared to the vitric tuffs that make up the same unit in the western part of the exploration block. Six sites containing either nonwelded vitric tuffs or nonwelded zeolitic tuffs were selected for study based on their similarity to the tuffaceous beds of Calico Hills within the exploration block (Fig. 1). These sites are:

1) vitric bedded tuffs at Busted Butte,

2) vitric bedded tuffs, northeast side of Yucca Mountain,

3) vituic ash-flow tuffs, south of Stagecoach Road,

4) zeolltic ash-flow tuffs, northeast side of Yucca Mountain (same location as \#2, but lower part of section),

5) zeolitic tuffaceous beds of Callco Hills at Prow Pass,

6) zeolitic tuffaceous beds of Calico Hills at Calico Hills.

This report presents 11 thologic, modal petrographic, chemical, mineralogic, and limited hydrologic data for outcrop samples collected from the sites described above. These data are compared to similar existing data sets for the tuffaceous beds of Calico Hills within the exploration block. A preliminary evaluation of the suitability of these sites to host a surface-based test facillty is made based on the similarity of rocks at these sites to the two principal rock lithologies found in the tuffaceous beds of Calico Hills within the exploration block. 


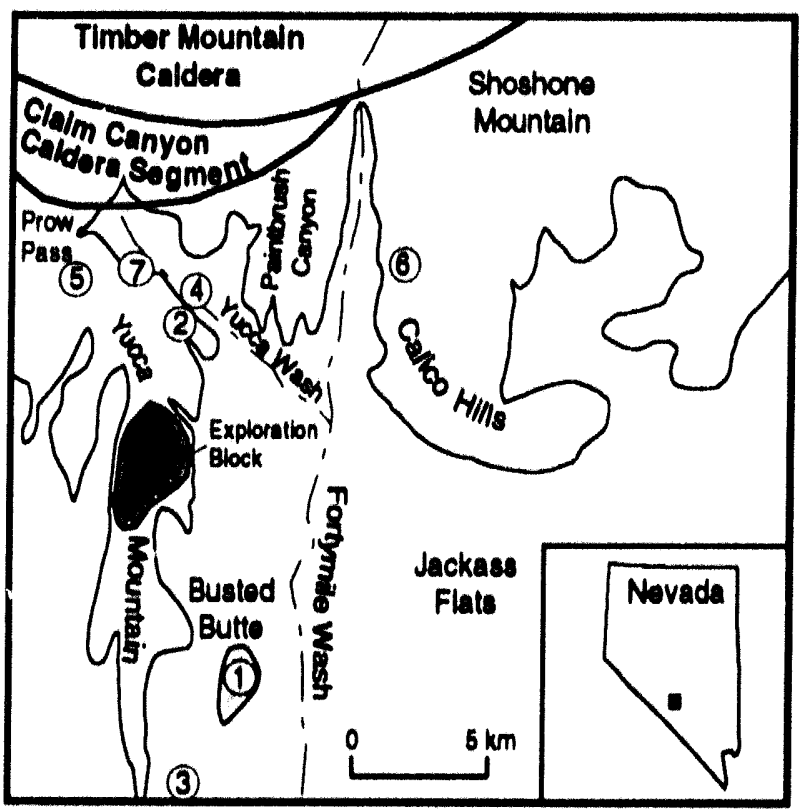

Fig. 1. Locations of outcrops of nonwelded vitric and zeollc: tuffs investigated for a potential surface-based teat facility in the vicinity of Yucca Mountain. Sites investigated include: 1) vitric bedded tuffs at Busted Butte, 2) vitric bedded tuffs, northeast side of Yucca Mountain, 3) vitric ash-flow tuffs, 5 $\mathrm{km} \mathrm{SW}$ of Busted Butte, 4) zeolitic ash-flow and bedded tuffs, northeast side of Yucca Mountain (same location as 12), 5) zeolitic tuffaceous beds of Calico Hills at Prow Pass,

6) zeolitic tuffaceous beds of Calico Hills at Calico Hills, and

7) the same stratigraphic sequence as at sites 2 and 4 but 2.2 km. northwent.
This work is a cooperative effort between Los Alamos National Laboratory, Sandia National Laboratory, and the U.S. Geological Survey. Los Alamos National Laboratory was responsible for selecting the sites that were investigated and for producing the lithologic, modal petrographic, chemical, mineralogic data presented in this report. Some of the samples and hydrologic information used in this study were collected as part of a Sandia National Laboratory investigation to estimate the spatial correlation structure of hydrologic propertles in tuff (for example, Rautman, 1991). Additional hydrologic information for these and other sites are being determined by the U.S. Geological Survey and Sandia National

Laboratory.

\section{METHODS}

Bulk rock samples were analysed for $\mathrm{SiO}_{2}$, $\mathrm{TiO}_{2}, \mathrm{Al}_{2} \mathrm{O}_{3}, \mathrm{Fe}_{2} \mathrm{O}_{3}$ (total), $\mathrm{MnO}, \mathrm{MgO}$, and $\mathrm{CaO}$ by $\mathrm{X}$-ray fluorescence (XRF). $\mathrm{Na}_{2} \mathrm{O}, \mathrm{K}_{2} \mathrm{O}, \mathrm{Sr}, \mathrm{Ba}$, and some $\mathrm{Fe}_{2} \mathrm{O}_{3}$ (total) abundances were determined by atomic absorption (AA) spectrophotometry. Abundances for $\mathrm{P}_{2} \mathrm{O}_{5}$ were determined by phosphomolybdate colorimetry (PMC) or by XRF. XRF $\mathrm{P}_{2} \mathrm{O}_{5}$ results below 0.08 wt. \% were rejected because of poor analytical precislon. Relatlve accuracies

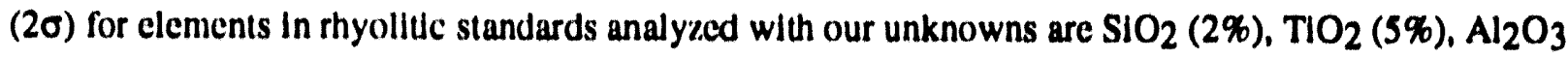
(3\%), $\mathrm{Fe}_{2} \mathrm{O}_{3}(10 \%), \mathrm{MnO}(5 \%), \mathrm{MgO}(20 \%), \mathrm{CaO}(5 \%), \mathrm{P}_{2} \mathrm{O} 5$ (30\%), $\mathrm{Na} 2 \mathrm{O}(5 \%), \mathrm{K}_{2} \mathrm{O}(5 \%), \mathrm{Sr}(20 \%)$ and $\mathrm{Ba}(20 \%)$. All XRF, AA, and PMC analyses were made by J. Husler at the University of New Mexico. Addlutional major and trace-element abundances were determined by neutron activation analyses (NAA) by S. Garcla of the Research Reactor Group at Los Alamos and by R. Korotev at Washington University in St. Louls. Uncertainties in the measured trace-element concentrations by NAA are usually less than 10\% at concentrations I order of magnitude above the detection limit. Korotev (1991), Minor et al. (1982), and Garcia et al. (1982) provlde additonal information about analytical uncertainties at various concentration levels, conditions of analysis, and detection llmits for elements analyzed by NAA. Loss on Ignition (I.OI) was determined by measuring the difference in sample welght at room temperature and after heating at $1(X 0)^{\circ} \mathrm{C}$ for one hour. 
Samples used for X-ray diffraction analyses (XRD) were first powdered in a tungsten-carbide shatter box and then mixed with an internal standard of $1 \mu \mathrm{m}$ metallurgical grade $\mathrm{Al}_{2} \mathrm{O}_{3}$ (corundum) powder in a ratio of $80 \%$ sample to $20 \%$ internal standard. The samples were then ground under acetone In an automatic Brinkmann-Retsch mill nitted with an agate mortar and pestle to produce an average particle size of less than $5 \mu \mathrm{m}$. This fine particle size is necessary to ensure adequate particle statistics and to minimize primary extinction (Klug and Alexander 1974, pp. 365-367). Particle size distributions have been verifled using a Horiba CAPA- 500 centrifugal particle size distribution analyzer callbrated with Duke Scientific glass microsphere standards.

$X$-ray diffraction (XRD) data were collected on a Siemens D-500 theta-theta diffractometer using copper-K $\alpha$ radiation, incident- and diffracted-beam Soller slits, and a Kevex solid-state (SILI) detector. Data were typically collected from 2.0 to $50.0^{\circ} 2 \theta$ using a $0.02^{\circ}$ step size for at least $2.0 \mathrm{~s}$ per step. Quantitative analyses employed the internal standard or "matrix-flushing" method of Chung (1974a,b), which requires that an Internal standard has been added to each sample. Detalls for analysis can be found In Bish and Chipera (1988; 1989).

Thin-section modal analyses (Appendix A) for percentages of phenocrysts, lithic fragments, pumice, shards, perlite chips (solid glass or altered glass fragments), and volds were performed following the procedures described In Byers (1985, p. 8-10; 1990a). Opaque oxide minerals in Appendix A were qualitatively identified using criteria outlined in Byers (1990b). These minerals are grouped together in the "Remarks" row of Appendix A.

A number of hydrologic properties have been determined for samples collected in several of these locations as part of a transect-sampling program being conducted jointly by the U.S. Geological Survey and Sandla National Laboratorles (Rautman et a., 1991; Rautman and Flint, 1992). The bulk hydrologic properties discussed in this report (porosity, bulk density, and particle density) were determined by gravimetry using Archimede's principle for volume determinations. Samples were saturated with water under a vacuum after displacement of air by $\mathrm{CO}_{2}$ gas to facilitate movement of water into small pores. Samples were weighed in their fully saturated state, both in air to determine the mass of rock plus water, and submerged to determine sample volume (Archimede's principle). Samples were then drled in a relative humidity oven at $60^{\circ} \mathrm{C}$ and 45 percent relative humidity and reweighed to determine the mass of rock without pore water. Drying samples under these conditions prevents the removal of water contained In the zeolite mineral structure or otherwise adsorbed on the pore walls (Bush and Jenkins, 1970; Soeder et al., 1991). The mass (volume) of water thus removed represents the volume of the pore space that is avallable for free movement of groundwater. These measurements allow direct calculation of porosity and bulk density. Particle density is then computed from the other two bulk properties. 


\section{RESULTS}

Appendix A summarizes modal petrographic data for samples investigated in this study.

Petrographic data for some of the samples from the Prow Pass area were previously reported by Broxton et al. (1989a) and are not repeated here. Appendix B presents mineralogic data determined by XRD. Major- and trace-element chemistry for these tuffs are presented in Appendix C. Sample locations and a key to sample field numbers, laboratory numbers, and Yucca Mountain ample tracking numbers are given in Appendix D.

Avallable hydrologic data for the sites Investgated are summarized in tables and figures in this ort. Numerical summaries of hydrologic data will be published by Sandia National Laboratory and the

Geological Survey in a separate report.

\section{A. Vitric Bedded Turfs at Busted Butte(Site th in Eie, 1$)$}

Vitric bedded tuffs crop out beneath the Topopah Spring Member in two locations at Busted Butte (Fig.

2). One of these locations is at the north end of Busted Butte, just east of the prominent northtrending fault that gives the butte its distinctive appearance. The second outcrop is on the southeastern side of the butte. Both outcrops are mapped as undivided tuffs (Lipman and McKay, 1965). Ejght samples were collected from the northern outcrop and seven samples were collected from the southeastern outcrop.

\section{Wlthology and Modal Petrography.}

a. Northern Outcrop. The outcrop at the north end of Busted Butte consists of a sequence of nonwelded ash-flow tuffs and bedded tuffs that Include, in ascending order, the Prow Pass Member of the Crater Flat Tuff, the Wahmonic Formation, the tuffaceous beds of Calico Hills, and the Topopah Spring Member (Fig, 3). This volcanic sequence has an aggregate thickness of $85 \mathrm{ft}$. from the lowermost exposures in the Prow Pass Member to the basal contact of the Topopah Spring Member. Outcrops of these tuffs are largely covered by Quaternary deposits

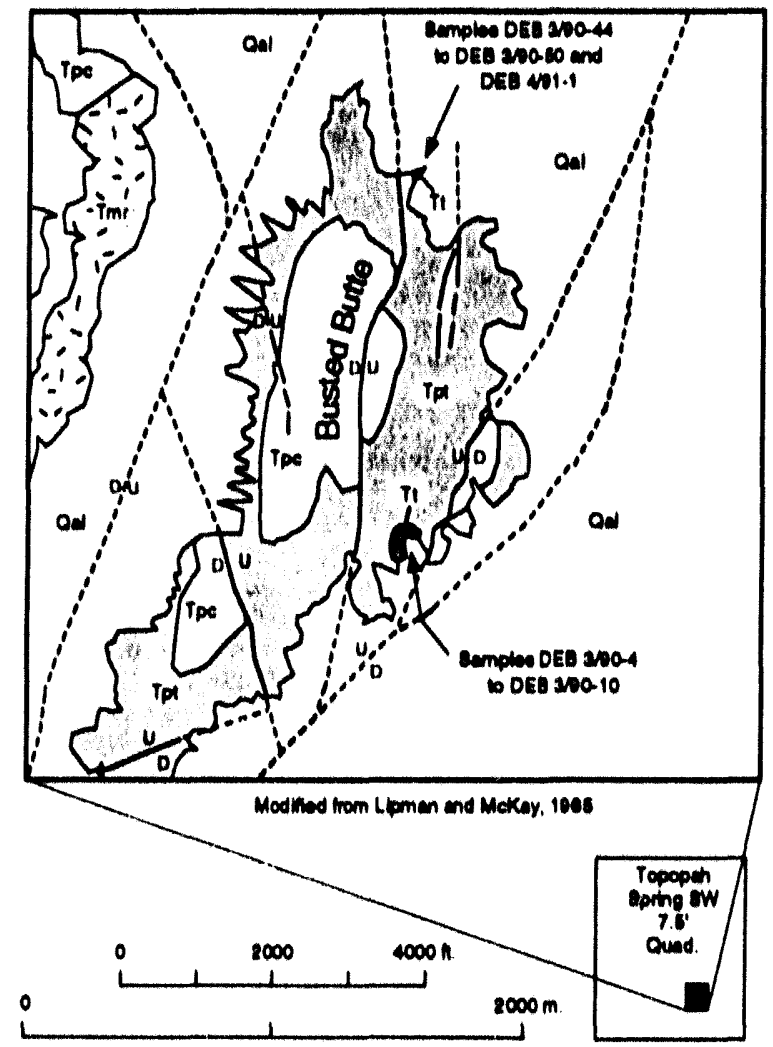

Fig. 2. Location of vitric bedded tuffs sampled at Busted Butte (Site 1 in Fig. 1). Samples were collected from the two outcrops labeled $\mathrm{Tt}$ at the north and southeast sides of Busted Butte. Geologic units shown on this figure include: (Tt) undivided bedded tuffs, (Tpt) Topopah Spring Member, (Tpc) Tiva Canyon Member, (Tmr) Rainier Mesa Member, and (Qal) Quatemary alluvium. 


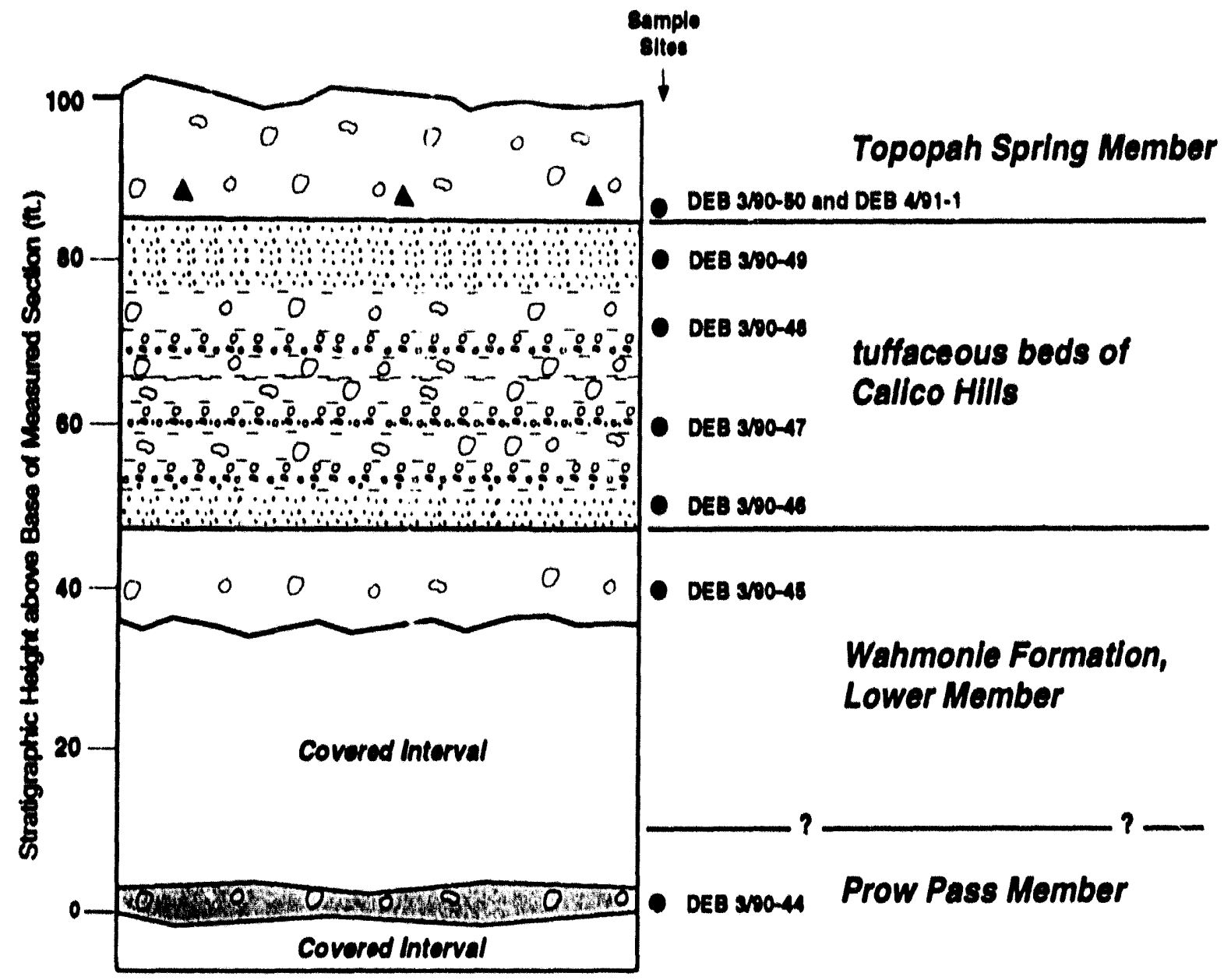

Q 0$]$ Massive nonwelded tuffs, probably mostly pyroclastic flow deposits; Pumice size proportional to O 0 size in tuli; Black triandes indcate lithic-rich zones.

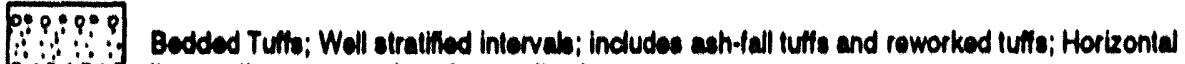
E.jes ines indicalo areas of crude etratilication.

Fig. 3. Stratigraphic section showing and sample locations within vitric bedded tuffs at the north end of Busted Butte (Site 1 in Fig. 1).

except in a deep north-trending gulch, which exposes bedrock beneath a blanket of colluvium and sand ramp deposits.

About $3 \mathrm{ft}$. of the upper part of Prow Pass Member is exposed at the base of the section in a small exposure of bedrock in the bottom of the north-trending gulch. The Prow Pass Member consists of nonwelded ash-flow tuff with brown pumice lapilli in a yellow to tan ashy matrix. The base and top of this Member are not exposed. The Prow Pass Member is approximately $130 \mathrm{ft}$. thick in outcrops $6 \mathrm{~km}$ to the southwest (McKay and Sargent, 1970). The one sample of Prow Pass Member collected at Busted Butte contains $9.2 \%$ phenocrysts comprised of sanidine, plagloclase, and wormy quartz with minor blotite, hornblende, and orthopyroxene (Appendix A, Fig. 4a). Accessory minerals include Fe-Tl oxides, 
(a)
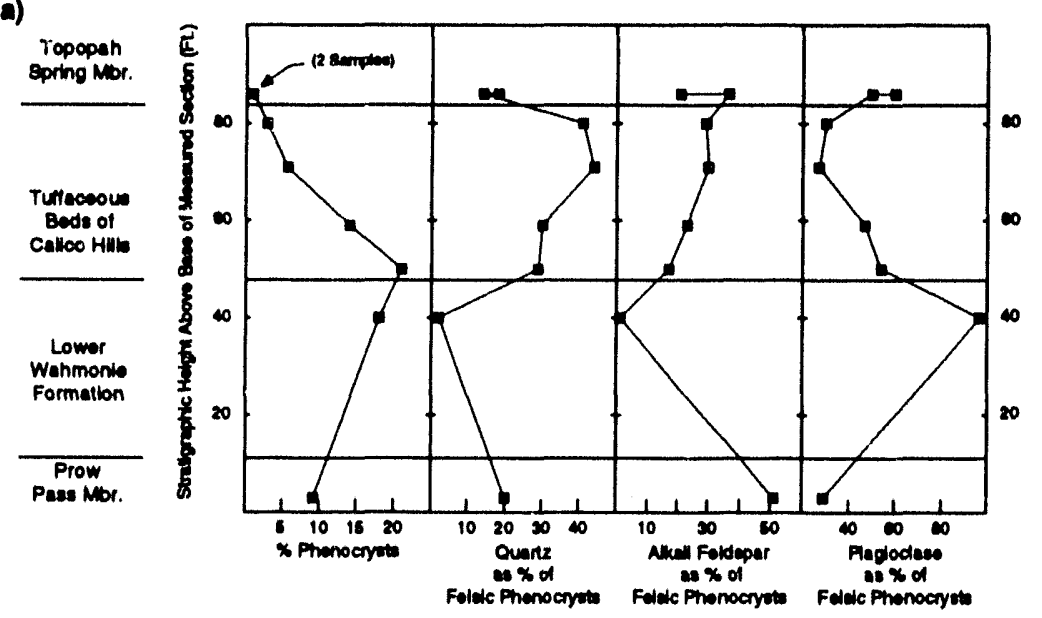

(b)

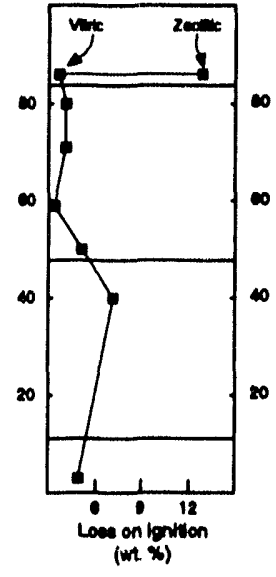

(c)

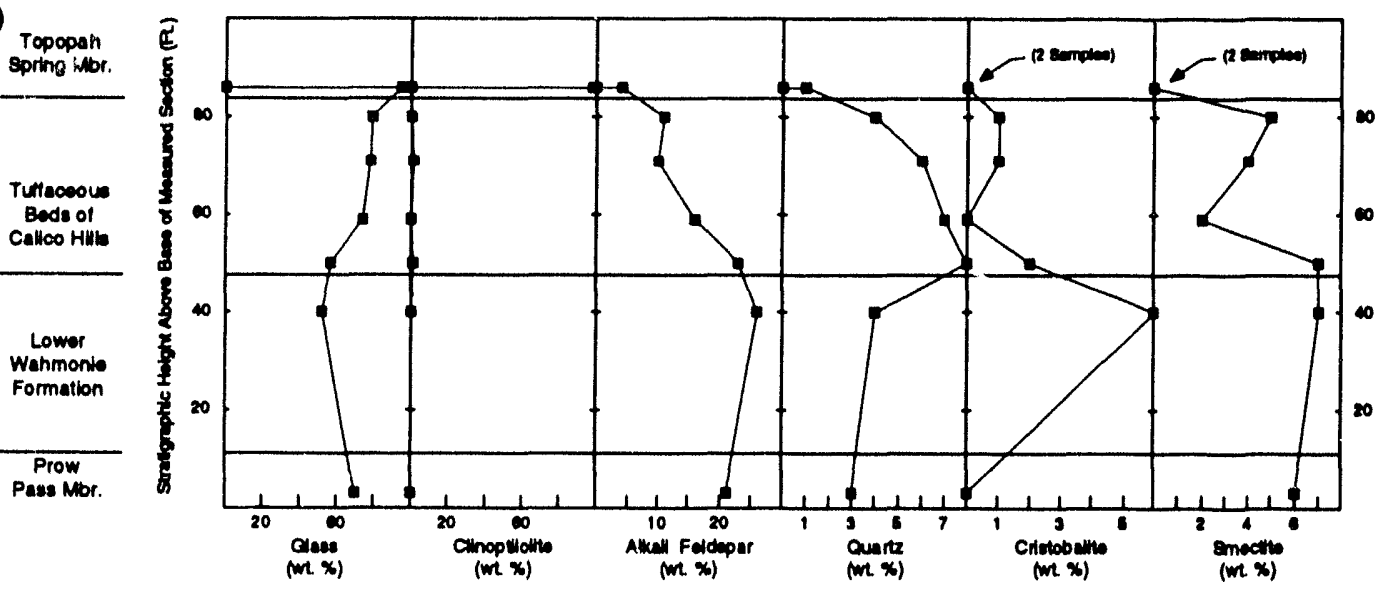

(d)

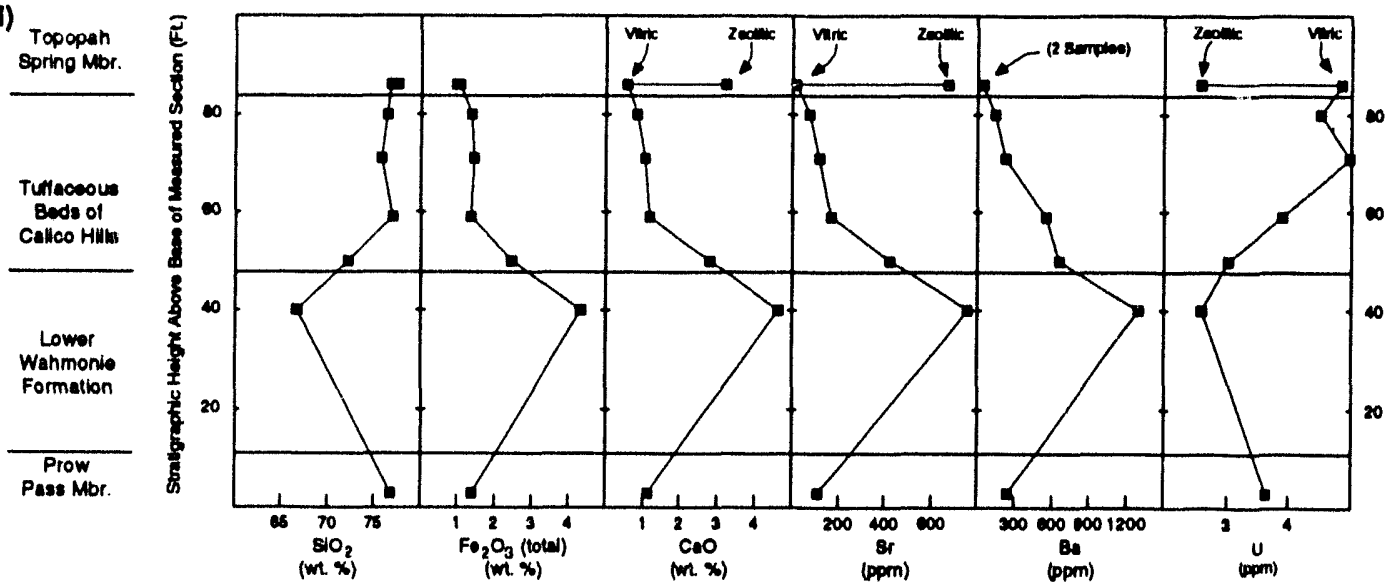

Fig. 4. Variation diagrams summarizing petrographic, mineralogic, and chemical characteristics of vitric bedded tuffs at the north end of Busted Butte (Site 1 in Fig. 1). The data are plotted as a function of stratigraphic position and include: a) modal petrography, b) total water contents (as loss on ignition), c) mineralogy, and d) chemistry. All samples are vitric tuffs excepted for the uppermost sample in the Topopah Spring Member which is a zeolitic next to a major N-S trending fault. 
allanite, apatite, and zircon.

Approximately $14 \mathrm{ft}$. of Wahmonie Formation is exposed at this location. The base of the unit is covered and the thickness of this tuff is probably closer to $40 \mathrm{ft}$. The Wahmonie Formation consists of a single ash-flow(?) tuff with sparse pink pumice lapilli in a tan ashy matrix. Phenocrysts make up $18 \%$ of the rock and consist of plagioclase, biotite, orthopyroxene, hornblende, and clinopyroxene (Appendix A, Fig. 4a). Accessory minerals include Fe-Ti oxides, apatite, and zircon. On the basis of its petrographic characteristics and stratigraphic position, this tuff correlates either with the lower part of the Wahmonie Formation or with the Salyer Formation as described by Poole et al. (1965) and Warren and Broxton (1986). The Wahmonie and Salyer Formations are very similar in their petrographic and chemical characteristics. All of the dacitic tuffs between the Prow Pass Member and the tuffaceous beds of Calico Hills are provisionally assigned to Wahmonie Formation until additional work can be done to resolve their stratigraphic assignment.

The tuffaceous beds of Calico Hills are a sequence of intercalated white ash-fall tuffs and lightbrown to pinkish-brown massive nonwelded tuffs and stratified reworked tuffs. This unit is $41 \mathrm{ft}$. thick with individual tuff layers ranging from a few inches to $4 \mathrm{ft}$. in thickness. The lower two-thirds of this unit is relatively crystal-rich containing 6 to $21 \%$ phenocrysts whereas the upper part contains only $3 \%$ phenocrysts (Appendix A, Fig. 4a). Phenocrysts throughout the unit consist predominately of quartz, sanidine, plagioclase, and biotite. Minor amounts of hornblende and pyroxene are present in tuffs near the base of the unit. Accessory minerals include Fe-Ti oxides, allanite, apatite, and zircon.

The base of the Topopah Spring Member is a white to tan nonwelded vitric ash-flow tuff. The thickness of this member below the basal vitrophyre is approximately $50 \mathrm{ft}$. The nonwelded tuffs at the base of the the Topopah Spring Member contain about 1\% phenocrysts consisting predominately of plagioclase and sanidine. Quartz occurs in small quantities ant may be xenocrystic. Mafic phenocrysts consist of biotite and trace amounts of hornblende. Accessory minerals include Fe-Ti oxides, allanite, apatite, and zircon.

b. Southeastern Outcrop. The outcrop on the southeastern side of Busted Butte is a sequence of nonwelded ash-flow tuffs and bedded tuffs that include, in ascending order, the Wahmonie Formation, the tuffaceous beds of Calico Hills, and the Topopah Spring Member of the Paintbrush Tuff (Fig. 5). This volcanic sequence has an aggregate thickness of $32 \mathrm{ft}$. from the lowermost exposures in the Wahmonie Formation to the basal contact of the Topopah Spring Member.

The Wahmonie Formation consists of light-colored massive to poorly-stratified ash-flow(?) tuffs. Approximately $11 \mathrm{ft}$. of Wahmonie tuff is exposed in this location. The base of the unit is covered and the actual thickness of this tuff may be much greater. The Wahmonie tuffs at this location are similar to the Wahmonie Formation described for the north end of Busted Butte. The unit contains 15\% phenocrysts of plagioclase, biotite, orthopyroxene, and clinopyroxene (Appendix A). Accessory minerals include Fe-Ti oxides, apatite, and zircon. 


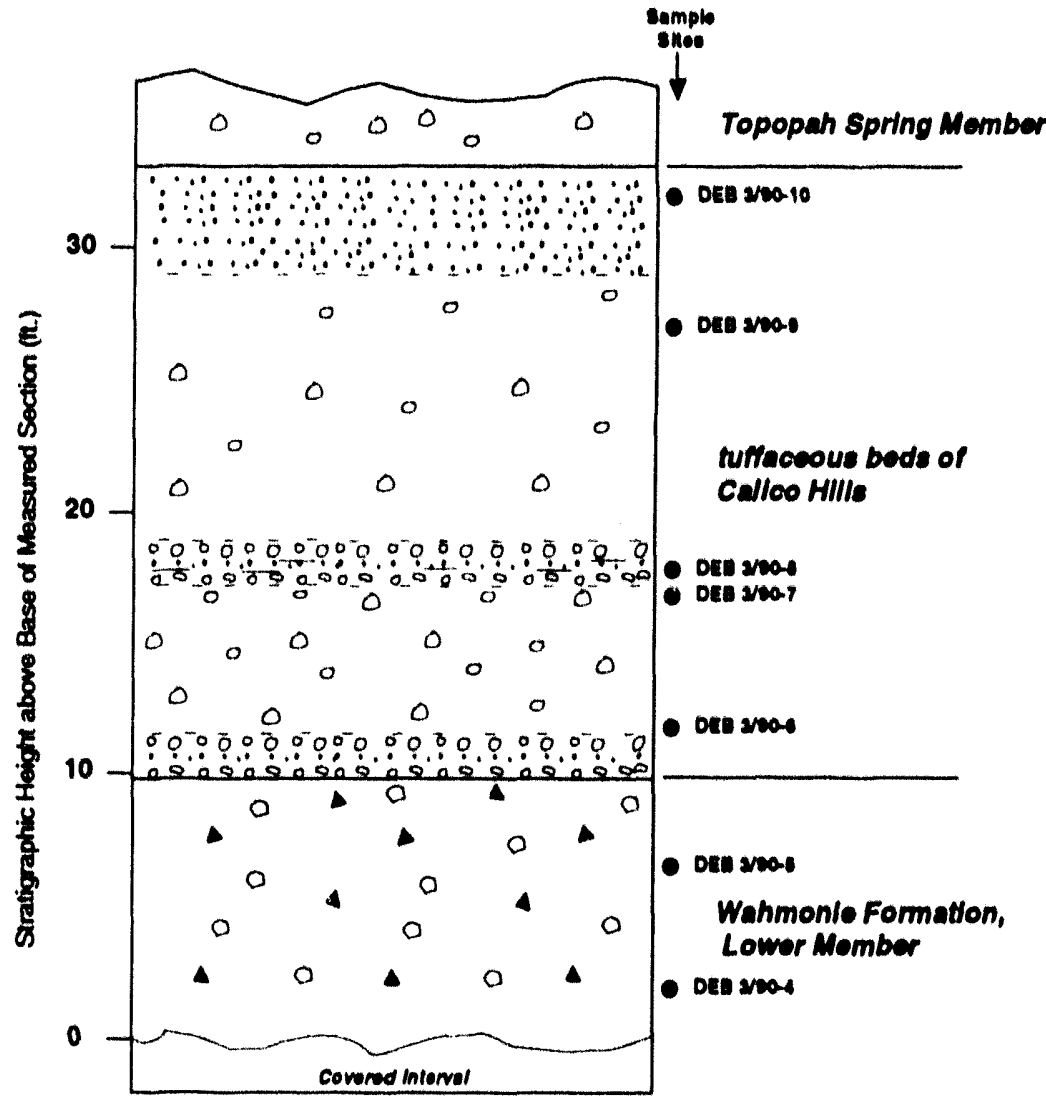

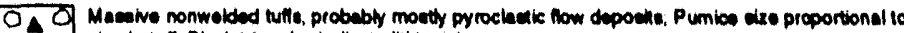

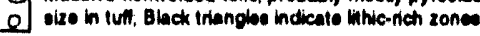

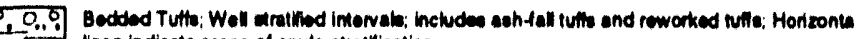

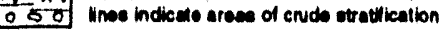

Fig. 5. Stratigraphic section and sample locations within vitric bedded tuffs on the southeast side of Busted Butte (Site 1 in Fig. 1).
The tuffaceous beds of Calico Hills are a sequence of intercalated, white ash-fall tuffs and light-brown and light-orange nonwelded tuffs and stratified reworked tuffs. This unit is $21 \mathrm{ft}$. thick with individual tuff layers ranging from a few inches to $12 \mathrm{ft}$. in thickness. The lower one-third of the unit is relatively crystal-rich as elsewhere and contains 7 to $9 \%$ phenocrysts, whereas the upper two-thirds of the unit contains less than 3\% phenocrysts. Phenocrysts throughout the unit consist predominately of quartz, sanidine, plagloclase, and biotlte (Appendix A). Minor amounts of hornblende and pyroxene are present in tuffs near the base of the unit.

Accessory minerals include Fe-TI oxides, allanite, apatite, and zircon.

The base of the Topopah Spring

Member is a white to tan nonwelded ash-flow tuff. No samples of the Topopah Spring Member were collected at this location, but its lithologic characteristics are similar to those described above for exposures at the north end of Busted Butte.

\section{Minerglogy}

The nonwelded tuffs at both outcrops studied at Busted Butte contain large amounts of volcanic glass and relatively few secondary minerals (Appendix B, Fig. 4c). The Prow Pass Member, tuffaceous beds of Calico Hills, and Topopah Spring Member generally contain 70-97\% glass whereas the phenocryst- and lithic-rich Wahmonie tuffs contain 46-54\% glass. In some samples, incipient diagenetic alteration of volcanic glass is indicated by the presence of small amounts of smectite (0-7\%) and clinoptilolite (0-12\%). Feldspar abundances range from 1 to $26 \%$ with the higher contents found in phenocryst- and lithic-rich tuffs. Together, quartz and cristobalite make up 1-10\% of the tuffs. 
Although the nonwelded tuffs at Busted Butte are largely unaltered, there is a local zone of zeolitization next to the major fault that bounds the western side of the northern outcrop. Next to this fault, the nonwelded base of the Topopah Spring Member is thoroughly altered to clinoptilolite ( $-98 \%$ ) and minor opal. Zeolitization extends downward to the base of the Topopah Spring Member but does not affect the underlying vitric tuffaceous beds of Calico Hills except in the westernmost part of the outcrop where this unit is closest to the fault. Zeolitization dies out eastward away from the fault.

\section{Chemistry}

The Prow Pass Member, the upper part of the tuffaceous beds of Calico Hills, and the Topopah Spring Member are high-silica rhyolites. The major-element chemistry of these tuffs is similar and their compositions are typical of these units elsewhere in the NTS region (Lipman et a., 1966; Quinlivan and Byers, 1977; Scott and Castellanos, 1984; Broxton et al., 1989b; Schuraytz et al., 1989; Spengler and Peterman, 1991). They generally contain 75.2-77.6\% $\mathrm{SIO}_{2}, 4.6-5.2 \% \mathrm{~K}_{2} \mathrm{O}, 2.6-3.4 \% \mathrm{Na}_{2} \mathrm{O}$, and 0.5$1.6 \% \mathrm{CaO}$, normalized to an anhydrous basis (Appendlx C, Fig. 4d). The phenocryst-rich base of the tuffacenus beds of Calico Hills is less sillcic $\left(72.2 \% \mathrm{SiO}_{2}\right)$ than the upper part of the unit. Volcanic glasses within the rhyolitic tuffs are hydrated, and whole-rock water contents average about $4 \%$ by welght (Fig. 4 b).

The Wahmonie Formation consists of calcic to calc-alkallc tuffs and lavas that grade upward chemically from dacite to dacite and andesite (Poole et al., 1965; Warten and Broxton, 1986; Broxton et al., 1989b). The Wahmonie tuffs at Busted Butte are dacites and are characterized by $66.6-67.0 \% \mathrm{SiO}_{2}$. 2.9-3.5\% $\mathrm{K}_{2} \mathrm{O}, 2.8-3.4 \% \mathrm{Na} 2 \mathrm{O}$, and 3.4-4.6\% CaO, on an anhydrous basis (Appendix C, Fig. 4d). Whole-rock water contents of these tuffs range from 2.8 to $7.1 \%$ by weight (Fig. $4 \mathrm{~b}$ ).

The zeolitic Topopah Spring Member next to the fault at the north end of Busted Butte is enriched in calcium $(3.2 \% \mathrm{CaO})$ and magneslum $(1.1 \% \mathrm{MgO})$ and depleted in potassium $\left(3.4 \% \mathrm{~K}_{2} \mathrm{O}\right)$ and sodium $\left(0.6 \% \mathrm{Na}_{2} \mathrm{O}\right)$ when compared to the vitric tuffs of the same unit on an anhydrous basis (e.g. compare samples DEB 4/90-1 and DEB 3/90-50, Appendix C). The water content of the zeolitic tuff is $12.8 \%$, assuming that the entire loss on ignition is due to water loss (Fig. 4b).

\section{Hydrologic Propertles.}

Hydrologic properties have not been determined for the vitric tuffs at Busted Butte.

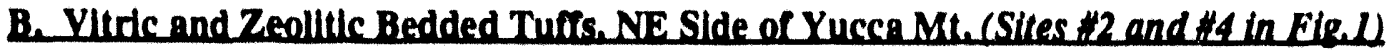

Nonwelded bedded tuffs crop out between the Topopah Spring and Yucca Mountain Members of the Paintbrush Tuff on the northeast side of Yucca Mountain (Fig. 6). These tuffs were included in this study because the upper part of this stratigraphic sequence (Fig. 1. Site \#2) is similar to the vituic portion of the tuffaceous beds of Calico Hills at Yucca Mountain and because these Paintbrush bedded tuffs are of general interest to hydrologists studying the movement of ground water in the unsaturated zone. The lower part of this sequence (Fig. 1, Site \#4) is zeolitized and may be suitable host rock for a surface-based 


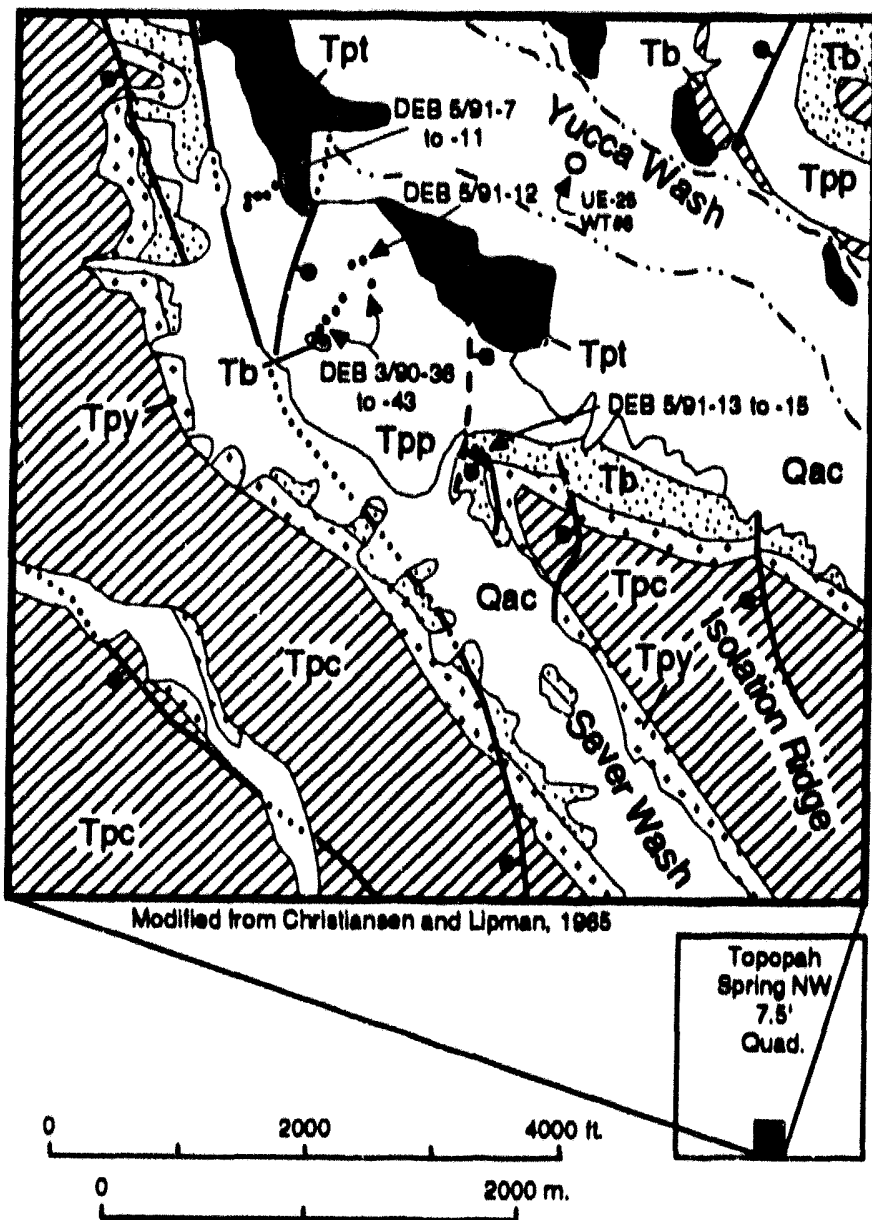

Fig. 6. Location of composite section of vitric tuffs (Sito 2 in Fig. 1) and zeolitic tuffs (Sito 4 in Fig. 1) sampled at northeastern Yucca Mountain. Samples (indicaled by dots) were collected from the bedded tuff beneath the Pah Canyon Member (not abown at this scale), the Pah Canyon Member, and bedded tuffs above the Pah Canyon Member. Geologic units include: (Tpt) Topopab Spring Member, (Tpp) Pah Canyon Member, (Tb) bedded luffs, (Tpy) Yucca Mountain Member, (Tpc) Tiva Canyon Member, and (Qac) Quatemary alluvium and colluvium. test facility in zeolitic tuff. Though treated as two seperate sites in their evalution as potentlal host rocks for a surface-based test facillty, these zeolitic and vitric tuffs are described together in ascending stratigraphic order because of their occurence in the same continuous stratigraphlc succession.

Samples of these vitric and zeolitic tuffs were collected west of the drill hole UE25WT-6 in a composite section which Includes, in ascending order, a bedded tuff assoclated with the uppermost part of the Topopah Spring Member (Christlansen and Lipman; 1965), the Pah Canyon Member of the Palntbrush Tuff, and a thick section of unnamed bedded tuffs above the Pah Canyon Member (Fig. 7). The upper bedded tuff units are the same as those designated as map unit Tpb (Paintbrush bedded tuffs) on the geologic map of Christiansen and Lipman (1965). A total of 17 samples were collected In the composite section.

\section{Wtholagy and Modal Petroaraphy}

A thin zeolitic bedded lapilli tuff overlies the quartz latitic caprock of the Topopah Spring Member at the base of the measured section. Pumice lapilli within this tuff are generally small $(0.5-1 \mathrm{~cm})$ and there is little or no ashy matrix between the clasts suggesting a pumice fall origin. The upper contact with the Pah Canyon Member is covered but the estimated thickness of the lapilli tuff is $10 \mathrm{ft}$. Phenocrysts make up $<1 \%$ of the tuff and consist of plagloclase, sanidine, and biotite (Appendix A, Fig. 8a). Accessory minerals Include Fe-Ti oxides, apatte, and zircon. The modal petrography of this tuff matches the lower, dominantly rhyolitic portion of the Topopah Spring Member.

The Pah Canyon Member is a simple ash-flow tuff cooling unit that is $245 \mathrm{ft}$. thick at this location. The lower $50 \mathrm{ft}$. of the tuff is nonwelded to partially welded and is pervasively altered to zeolites, the upper $\mathbf{5 0} \mathrm{ft}$. is nonwelded and is vitric, and the remainder of the unit is partially to moderately welded and is devitrifled to an assemblage of high-temperature nonhydrous minerals (Fig. 7). Vapor- 


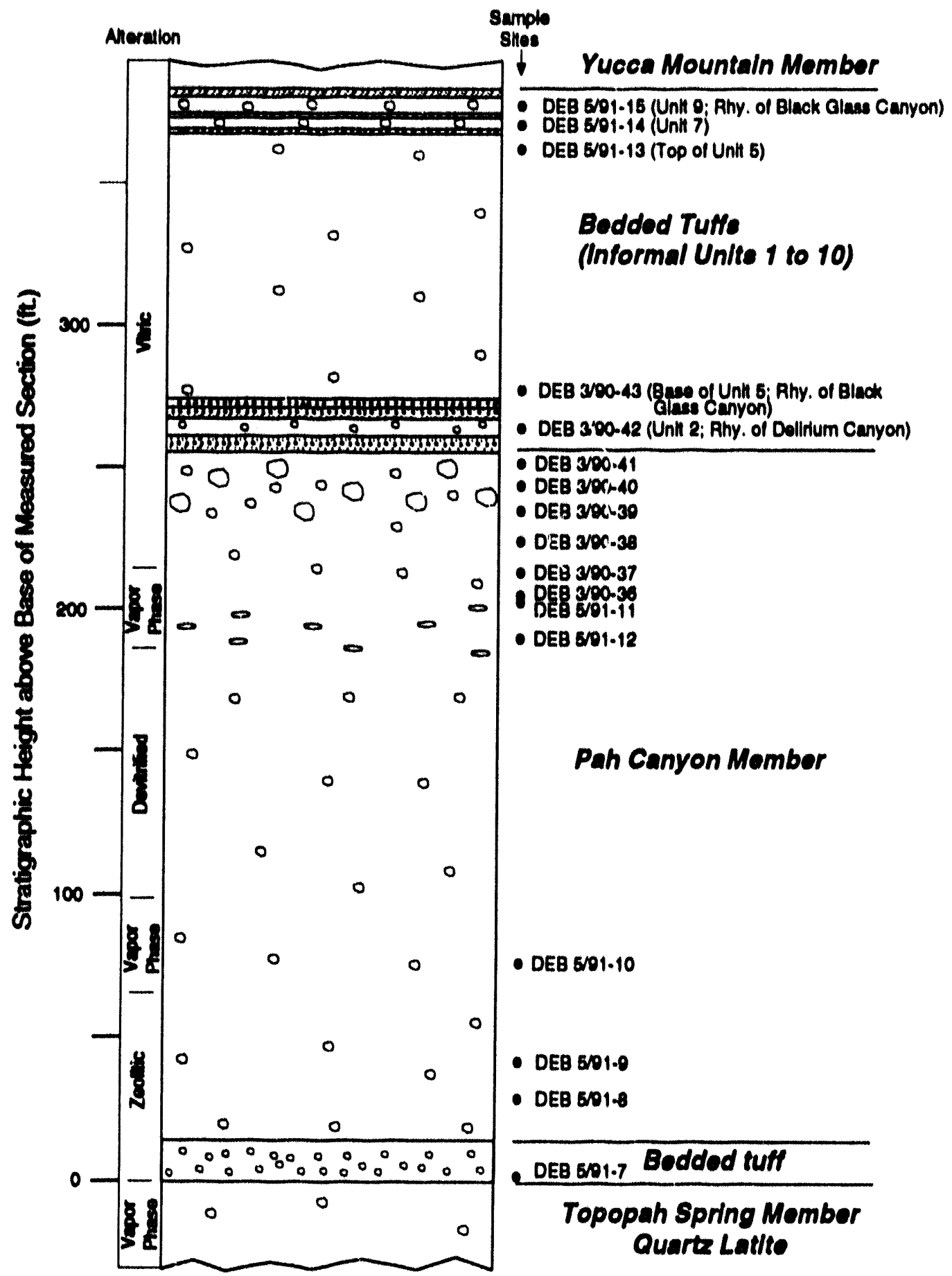

Ach-flow tufts; Pumice size and flattening proportional to cizo and hattening in tuft.

$29: 909$ Hoj

Bedded Tufls; Woll stratified intervals; mostly ach-fall tufis and reworked tufis.

Fig. 7. Composite stratigraphic section and sample locations for vituc tuffs (Site 2 in Fig. 1) and zoolitic tuffe (Site 4 in Fig. 1) at northeastorn Yucca Mountain. Potential host rocks for a surfacebased lest facility include zeolitic tuffe at the base of this stratigraphic sequence and vitric tuffs at the top. 
phase alteration occurs in two zones in the middle, partially- to moderately-welded subunit. The upper vapor phase zone forms a resistant ledge $30 \mathrm{f}$. thick 190 to $210 \mathrm{ft}$. above the base of the unit. The lower zone of vapor phase alteration is located 75 and $100 \mathrm{f}$. above the base of the member. The Pah Canyon Member contains 3.6-11.3\% phenocrysts of sanidine, plagloclase, blotite, and clinopyroxene (Appendix A, Fig. 8a). Accessory minerals include Fe-TI oxides, sphene, perrlerite, apatite, and zircon.

Bedded tuffs above the Pah Canyon Member have an aggregate thickness of $125 \mathrm{f}$. and consist of vitric ash-fall tuffs, reworked tuffs (7), and ash-flow tuffs. They are subdivided into 10 iniormal subunits based on differences in bedding features and mode of deposition (Fig. 7). The ash-fall and reworked tuffs are generally thin (0.5-5 $\mathrm{f}$.) and are characterized by well-defined stratiflcation imparted by grading and sorting of clasts. Four tuffs are clast-supported lapilli tuffs and contain little or no ashy matrix; these tuffs are probably pumice-fall deposits. Four ash-flow tuffs are intercalated with the bedded tuffs in this sequence; three of ash flows are thin (3.7 to $7 \mathrm{f}$.) and the fourth is relatively thick ( $95 \mathrm{ft}$.). All four of the ash-flow turfs are nonwelded and massive. All subunits in the bedded tuff sequence above the Pah Canyon Member are phenocryst poor (2-3\%) and contain sanidine, plagloclase, hornblende, and blotite as primary phenocrysts (Appendix A, Flg. 8a). The plagioclase content of the lowermost ash-flow tuff is signiflcanlly greater than in the upper three ash-flows, which are nearly plagloclase free. Hornblende to bioute ratios increase in the upper three ash-flows relattve to the lowermost one. Fe-TI oxides, sphene, perrierite, apatite, and zircon comprise the accessory minerals in all four ash-flows.

\section{Mineralogy.}

The base of the Pah Canyon Member and the underlying lapilli tuff are altered to clinopulolite (68-75\%), mordenite (0-13\%), and opal (Appendix B, Fig. 8c). The zeolltic zone gives way upsection to a zone of high-temperature devitriflcation and vapor-phase alteration which is dominated by alkall feldspar and cristoballte; tridymite is detected in one sample from the lower vapor-phase zone. Small amounts of clinopulolite and mordenite are found in both upper and lower vapor-phase zones. The upper part of the Pah Canyon Member is a nonwelded vitric tuff that contains 68-85\% volcanic glass. Inciplent alteration of these vitric tuffs is suggested by the presence of 1-11\% smectite.

The bedded tuffs above the Pah Canyon Member consist predominately of volcanic glass (6382\%) and alkall feldspar (9-27\%). The principal sllica phases are quartz and cristobalite, which together make up less than $4 \%$ of the tuffs. Inciplent alteration is indlcated by the presence of small amounts of smectute (1-17\%) and clinopulolite (0-2\%).

\section{Chemistry}

The zeolitic lapilli tuff at the base of the section (DEB 5/91-7) has the Immobile major- and traceelement chemistry of a high-sillca rhyolite (Appendix C, Fig. 8d). Concentrations of $\mathrm{TIO}_{2}(0.10 \%)$, Hf (4.9 ppm), Sc (2.4), Nd (28 ppm), and Eu (0.3 ppm) closely match the rhyolitic portlon of the Topopah Spring Member. The lapilli tuff overlies the quartz lattlic caprock of the Topopah Spring Member and probably represents a late eruptive phase that tapped Topopah Spring rhyolitic magma that remained in 
(a)
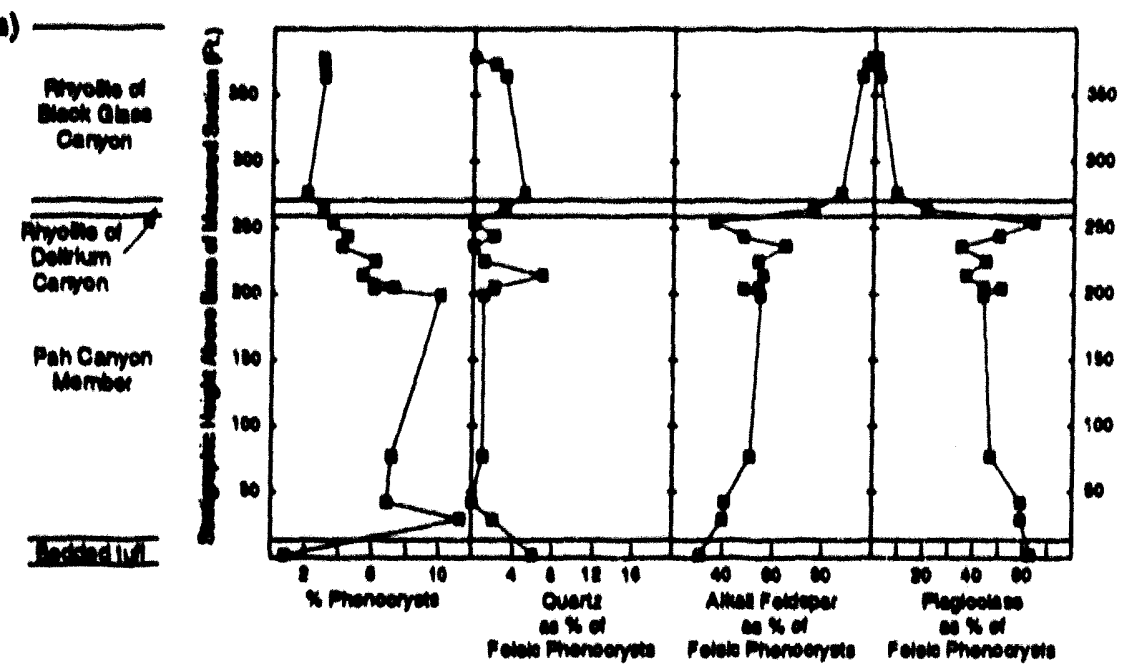

(o)

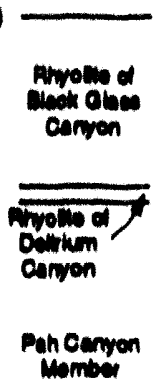

FताII

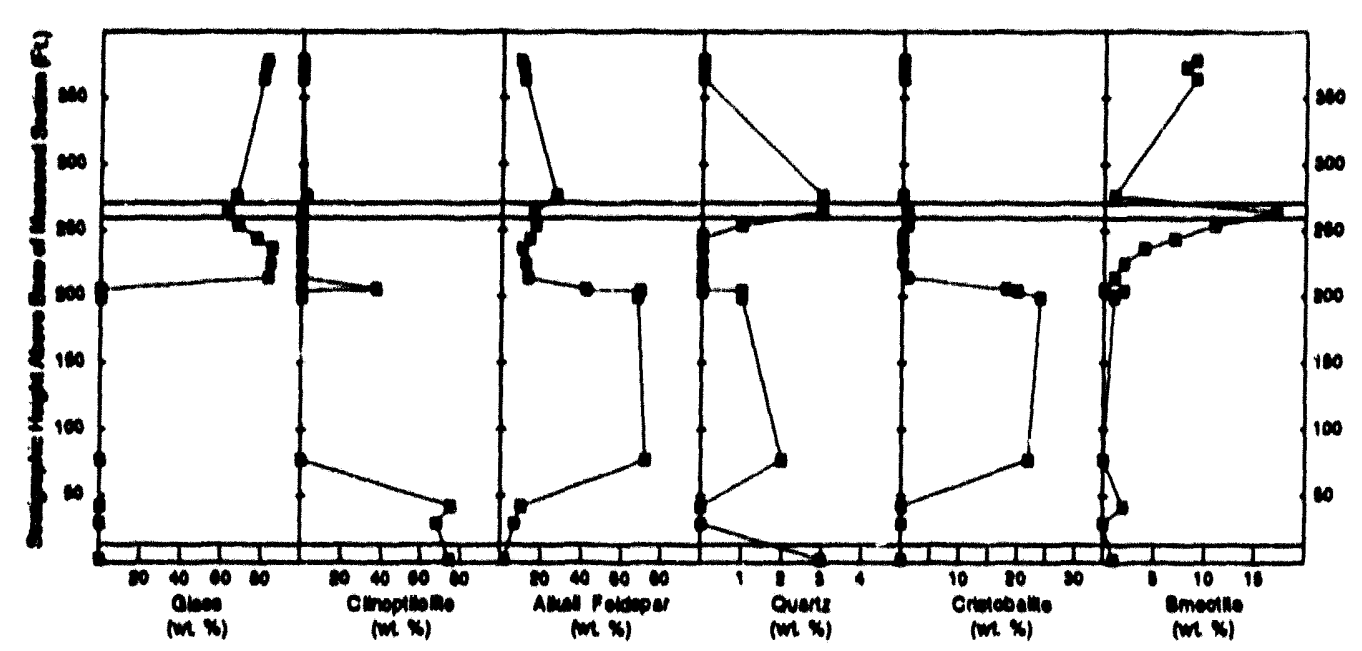

(d)

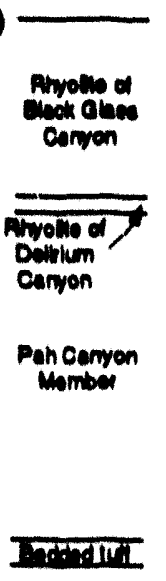

(b)

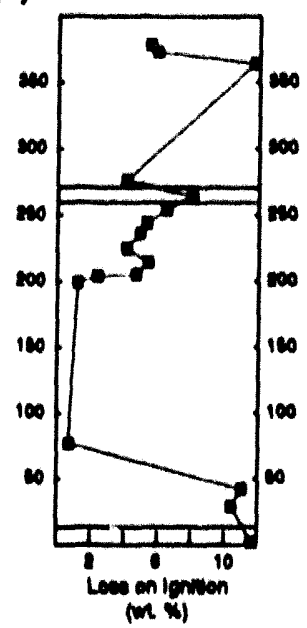

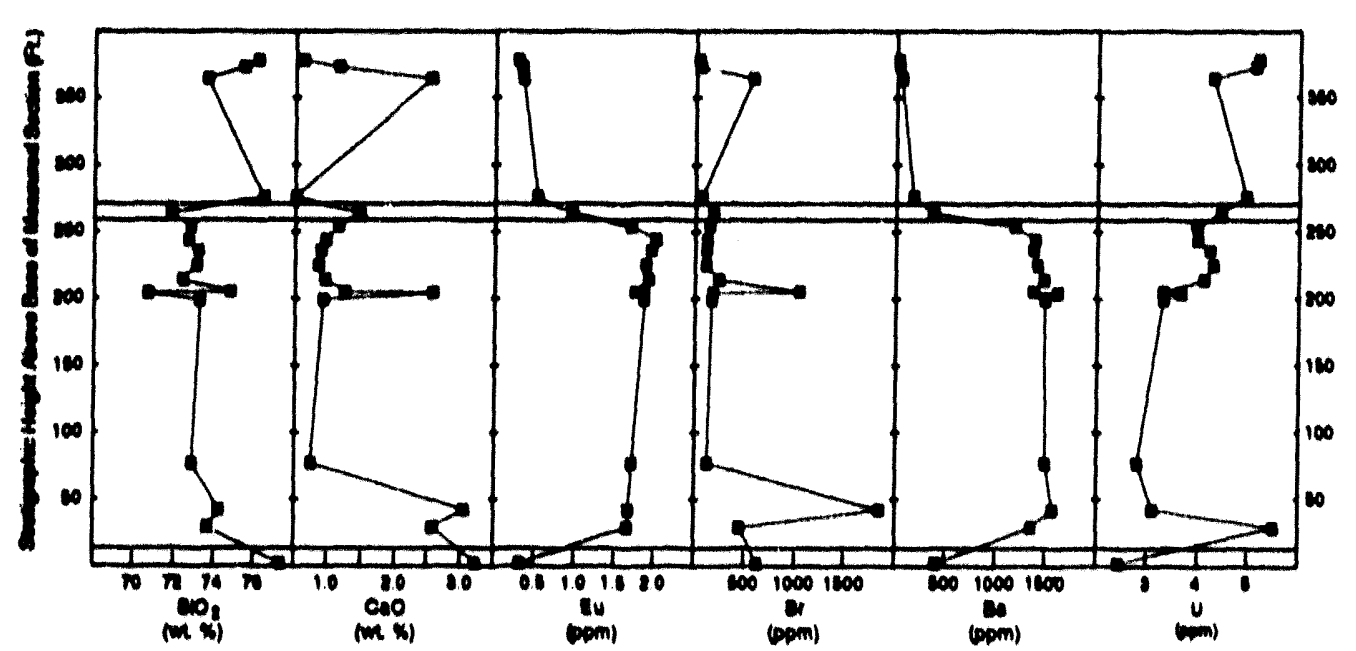

Fig. 8. Veriation diagrums summarizing petroeraphic, mineralogic, and chemical characteristics of vituic tuffi (Sile 2 in Fig. 1) and zeollite tuffe (Site 4 in Fis. 1) at the nortbeastern Yucca Mountain. Data plotted as a function of atratigraphic ponition include: a) modal potrography, b) total water contents (as loas on ignition), c) mineralogy, and d) chemistry (normalized to an anhydrous basite). 
the magma chamber after the maln ash-flow tuffs were emplaced. Christlansen and L.pman (1965) Include this bedded tuff in the Topopah Spring Member.

The Pah Canyon Member is Intermediate In chemical composition between the high-silica rhyollte and quartz latite of the Topopah Spring Member (Byers et al., 1976; Quinlivan and Byers, 1977; Flood et al., 1989; Broxton et al., 1989b). Vitric and devituified tuffs of the Pah Canyon Member are characterized by 72.4-73.7\% $\mathrm{SIO}_{2}, 4.6-6.4 \% \mathrm{~K}_{2} \mathrm{O}, 3.2-4.0 \% \mathrm{Na}_{2} \mathrm{O}, 0.8-1.1 \% \mathrm{CaO}, 1184-1611 \mathrm{ppm} \mathrm{Ba}$, 78.94 ppm La, 34-78 ppm Nd, 1.7-2.0 ppm Eu, 2.8-3.7 ppm U, and 20.1-23.9 ppm Th, on an anhydrous basis (Appendix C, Fig. 8d). On average, the vitric tuffs contain about $12 \%$ less $\mathrm{Na}_{2} \mathrm{O}$ than the devitrined tuffs, probably because of inciplent smectituc alteration in the vitric tufrs. The zeolltic tuffs at the base of the Pah Canyon Member and the underlying lapilli tuff are calcium-rich $(1.24-3.23 \% \mathrm{CaO})$ and sodjum-poor (0.96-2.14\% Na2O) compared to the vitric tuffs (Appendix C, Fig. 8d). Zeolitic tufrs with similar composituons are found in the Pah Canyon Member In drill hole USW O-2, one kjlometer to the west (Broxton et al., 1986).

The four ash-now tuffs of the bedded tuff sequence above the Pah Canyon Member were sanpled for major- and trace-element chemistry. The lowermost ash-flow tuff (informal unit 2 in Fig. 7) is characterized by $71.8 \% \mathrm{SIO}_{2}, 4.2 \% \mathrm{~K}_{2} \mathrm{O}, 3.3 \% \mathrm{Na2}$, 1.46\% CaO, $370 \mathrm{ppm} \mathrm{Ba,} 79$ ppm Sr, 60 ppm La, $47 \mathrm{ppm}$ Nd, $0.96 \mathrm{ppm} \mathrm{Eu}, 24.6 \mathrm{ppm}$ Th, and $4.45 \mathrm{ppm} \mathrm{U}$, on an anhydrous basis (Appendix C, Fig. 8d). This lowermost ash-flow tuff is generally similar in major-element chemistry to the low-sillca rhyolite of the Pah Canyon Member, but it has trace clement characteristles (e.g., higher $U$ and $T$ and lower $\mathrm{Ba}$ and I.REE) that clearly distingulsh It from the Pah Canyon. Based on its distinctive chemistry and petrography, this lowermost ash-flow tuff probably is correlative w/th the rhyollte of Delirlum Canyon (Christiansen and L.Jpman, 1965; Warren et al., 1988; R. O. Warren, personal communication). The upper three ash-now tuffs (Informal units 5, 7, and 9 in Fig. 7) have similar chemical and petrographic characteristics and are more evolved chemically than the lowermost ash-flow tuff. For example, the uppermost ash-flow tuff contains $76.1 \% \mathrm{SIO}_{2}, 4.9 \% \mathrm{~K}_{2} \mathrm{O}, 3.2 \% \mathrm{Na}_{2} \mathrm{O}, 0.6 \% \mathrm{CaO}, 19 \mathrm{ppm} \mathrm{Ba}, 25 \mathrm{ppm}$ Sr, $29 \mathrm{ppm} \mathrm{La,} 20 \mathrm{ppm} \mathrm{Nd,} 0.27 \mathrm{ppm} \mathrm{Ku,} 25.6 \mathrm{ppm} \mathrm{Th}$, and $4.9 \mathrm{ppm} \mathrm{U}$, on an anhydrous basis (Appendlx C. Fig. 8d). Based on a comparison of chemistry and petrography, these three ash-flow tuffs probably are correlative with the rhyollte of Black Glass Canyon (Christlansen and Lipman, 1965; Warren et al., 1988; R. (j. Warren, 1992 personal communication).

\section{Hydrologilc Propertles,}

Hydrologic properties were measured for samples from a laterally equivalent section of tuffs (site \#7) located approximately $2.2 \mathrm{~km}$ northwest of the sites $\$ 2$ and $\# 4$. Hydrologic data from site $\$ 7$ should closely approximate the hydrologic properties of the tuffs comprising the composite stratigraphic section at sites $\# 2$ and $\# 4$.

Tuffs in this stratigraphic intcrval vary in porosity from 12 to 55\%, with an average porosity value of $35 \%$ and a standard deviation of $11 \%$. The average bulk density is $1.55 \mathrm{~g} / \mathrm{cm}^{3}$ and particle 
TABLE I.

HYDROLOGIC PROPERTIES OF THE PAH CANYON MEMBER AND BEDDED TUFFS ON THE NORTHEAST SIDE OF YUCCA MOUNTAIN, NEVADA*

\begin{tabular}{|c|c|c|c|}
\hline $\begin{array}{c}\text { Hydrologic Property } \\
\text { with Mean } \pm \text { Sid. Dev. }\end{array}$ & $\begin{array}{c}\text { Combined } \\
\text { Section } \\
(n=44)\end{array}$ & $\begin{array}{c}\text { Pah Canyon } \\
\text { Member } \\
(n=33)\end{array}$ & $\begin{array}{c}\text { Bedded Tufrs Above } \\
\text { Pah Canyon Mbr. } \\
(n=9)\end{array}$ \\
\hline Porosity \% & $35 \pm 11$ & $33 \pm 12$ & $39 \pm 4$ \\
\hline Range & $12.55(44)$ & $12 \cdot 53$ & $33 \cdot 51$ \\
\hline Bulk Density $/ \mathrm{cm}^{3}$ & $1.55 \pm 0.30$ & $1.01 \pm 0.33$ & $1.41 \pm 0.11$ \\
\hline Range & $1.05 \cdot 2.17$ & $1.05 \cdot 2.17$ & $1.13 \cdot 1.57$ \\
\hline Particle Densily $/ \mathrm{cm}^{3}$ & $2.38 \pm 0.11$ & $2.41 \pm 0.12$ & $2.29 \pm 0.04$ \\
\hline Rangeb & $2.13 \cdot 2.58$ & $2.13 \cdot 2.58$ & $2.23 \cdot 2.35$ \\
\hline
\end{tabular}

a. S16 177 in Plg. 1 .

densitues are between 2.13 and $2.58 \mathrm{~g} / \mathrm{cm}^{3}$ (Table I). Hydrologlc properties vary complexly as a function of vertical stratigraphic position (Fig. 9). These varlations are controlled by vertical changes in Ilthology both between and within Individual stratjgruphic units.

Porositues for the Pah Canyon Member vary from 1210 55\% and average 33\% (Table I). Porosity values for the unt reflect a classical welding profle, ranging from 37 to $38 \%$ at the zeolluc nonwelded base. 12 to $43 \%$ in the partially- to moderately-welded devitufined interior, and 47 to 55\% in the vituic nonwelded top (FI8. 9). By contrast, porositjes of the bedded turf units vary between 33 and $51 \%$ and
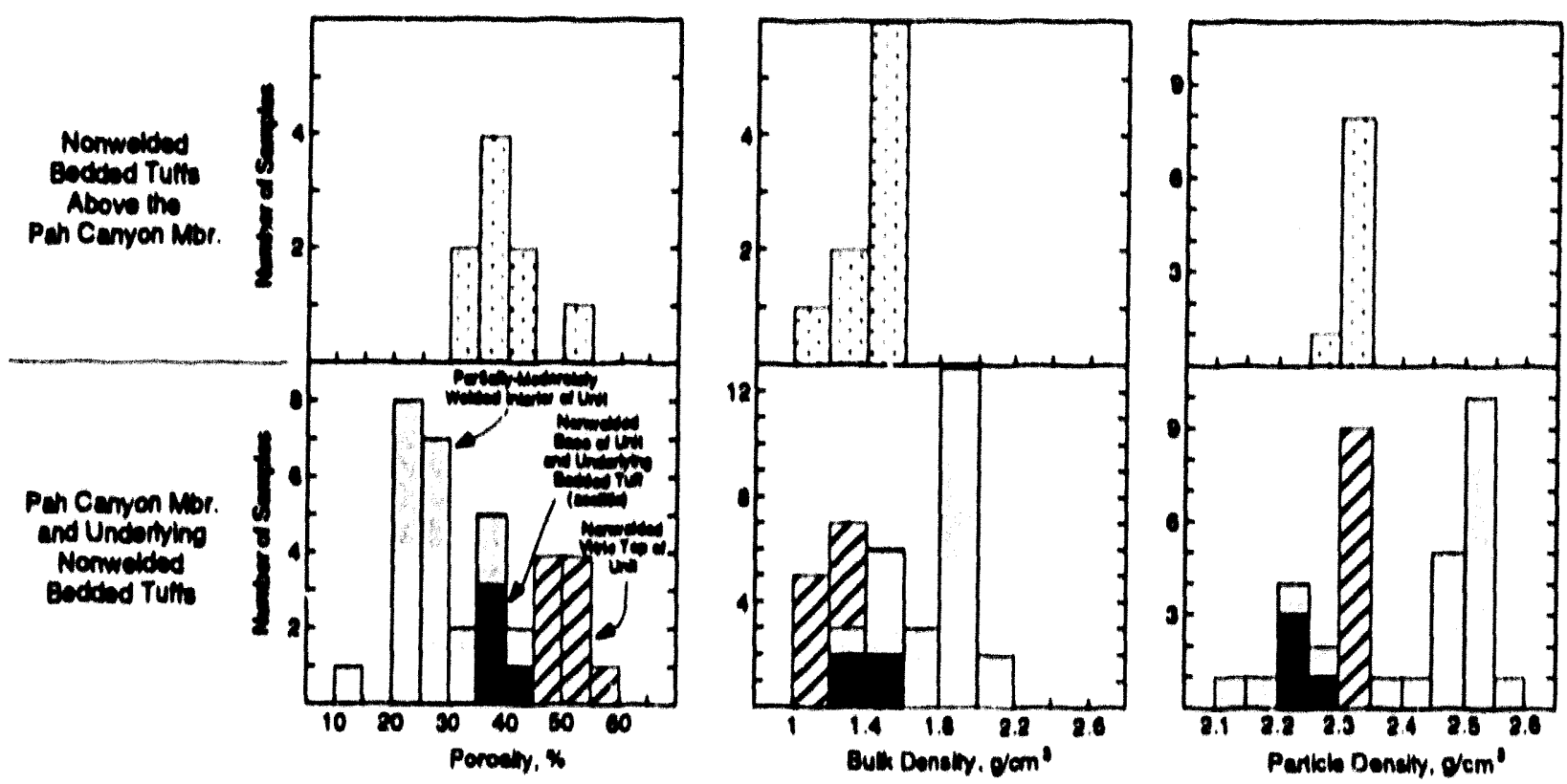

Pis. 9. Stecked bistograms of porosity, bulk density, and particle densily for vitite and zeolitie luffa al the northoastom Yucica Mountain (Sile 7 in Fig. 1). 
average $39 \%$. The more limlied varlabilliy of all hydrologle propertles measured for bedded tufrs above and below the Pah Canyon Member renects a lack of welding. Teolltic samples from the the bedded tuff beneath the Pah Canyon Member and from the lower part of the Pah Canyon Member have porositles $(-38 \%)$ and particle densities $\left(-2.24 \mathrm{~g} / \mathrm{cm}^{3}\right)$ that are similar to the vitric bedded tuffs above the Pah Canyon Member ( $39 \%$ and $-2.33 \mathrm{~g} / \mathrm{cm}^{3}$ respect/vely), although the data set to support this conclusion is small.

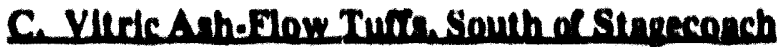

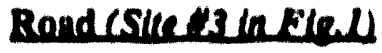

The Prow Pass Member is exposed in northtrending outcrops south of Slagecoach road, $5 \mathrm{~km}$ southwest of Busted Butte (Fig. 10). Samples were collected from nonwelded tuffs at the base of the Member and from thin overlying bedded iuffs of the Wahmonic Formation. Only three samples (two from the Prow Pass Member and one from the Wahmonic Formation) were collected from this locatlon because It was evident from our preliminary examination of the site that less altered vitsic tuffs, which better represent the tuffaceous beds of Calleo Hills, could be

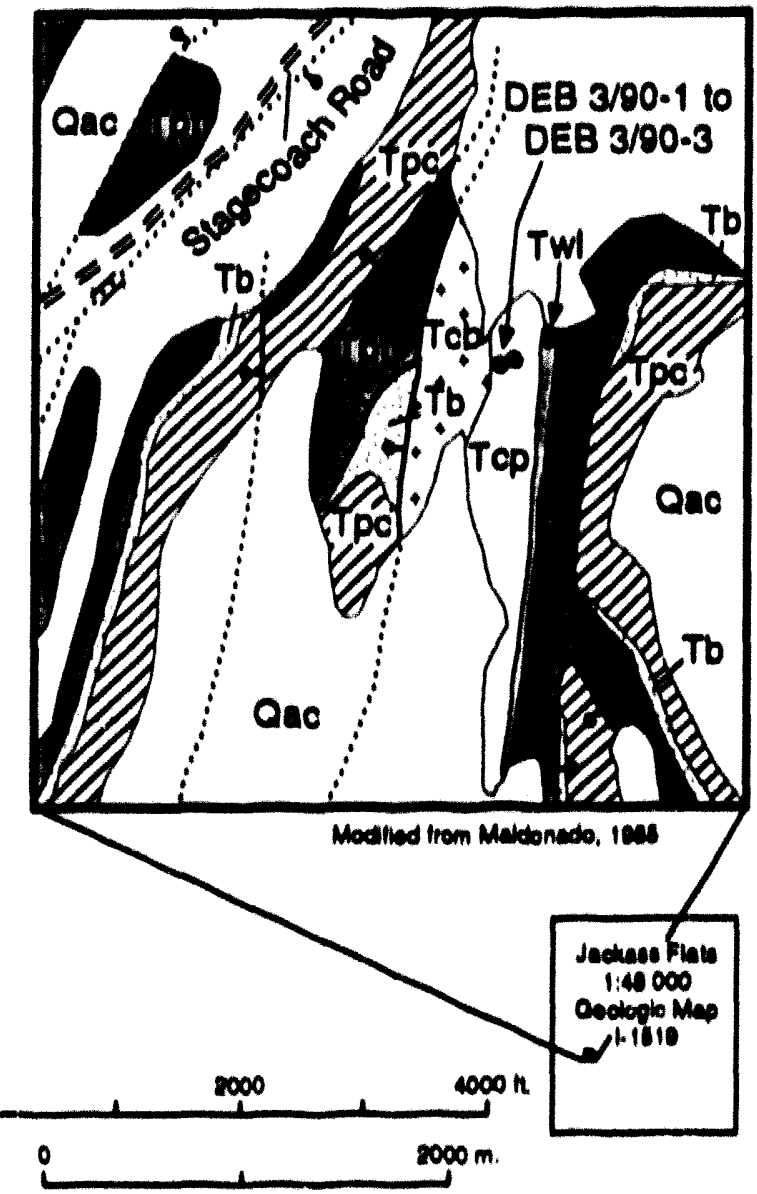

Pis. 10. Location of vitric wh. How turfe umpled at outcrops $5 \mathrm{~km}$ SW of Butted Butle, in the vicinity of Sugecoech Roed (Sile 3 in Pig. 1). Semplen wore collected from the lower part of the Prow Paus Member. Geologle units shown on this figure include: (Tcb) Bullfros Member, (Tep) Prow Pase Member, (TwI) Wahmonje lormation (lower part), (Tpk) Topopah Sprin! Member, (Tb) bedded tuff, (Tpc) Tiva Canyon Member, and (Qac) Quacemary alluvium and colluvium. found at other locations.

\section{Whology and Modol Patroerenhy.}

The Prow Pass Member is a simple cooling unlt approximately $130 \mathrm{n}$. thlck at this location. The lower $50 \mathrm{n}$. of the unit is nonwelded tuff that is partially vituic, but II contains beds and cyllndrical to irregular enclaves that are partially zeolitic. The upper part of the unit is a partially- to moderately. welded tuft that has undergone high-lemperature devitriflcatlon. The base of the moderately-welded turfs forms a resistant ledge that is a useful marker bed. Nonwelded tuffs sampled frum the base of the unlt contain 6.5.6.9\% phenocrysts of sanidine, plagioclase, quartz, biotite, and orthopyroxene (Appendix A). Accessory minerals Include Fe-Ti oxides, allanite, apatile, and zircon.

The Itrow Pass Member is overlain by $10 \mathrm{n}$. of light-colored massive to poorly-bedded tuff of the Wahmonie Formation. Tuffs of the Wahmonie Formation at this location are similar to those at Busted 
Butte and have petrographlc characteristics typlcal of the lower part of the formation. The sample collected from this unit contalns 14\% phenocrysts of plagloclese, blotte, orthopyroxene, and clinopyroxene (Appendix A). Accessory minerals Include Fe-TI oxides, apatte, and zircon.

\section{Minerlogy.}

The lowermost umple collected at the base of the exposed section is altered to clinoptllolite (64\%), mordente (3\%) and opal (Appendix B). A second sample collected $25 \mathrm{~A}$. higher in the sequence Is s sllghtly sliered vitric tuff (68\% glass and 5\% clinopullolite) that is locally altered to zeolites ( see Lab. 158, PZA in Appendix B). In this sample, zeolitization occurs as a cylindrical zone of alteration 2 to 3 In. In diameter within a vituic host rock. The zeolitic tuffs probably represent zones of greater alteration along preferred ground water pathways. No clear boundary separates tuffs that are dominanily zeolltc from those that are dominantly vitulc.

No XRD analyals was made for the bedded Wahmonle tuff above the Prow Pass Member. This unit ls lergely vitulc based on the petrographic examination (Sample DEB 3/90-3 In Appendix A).

\section{Chamintry}

The vitutc tuff in the lower part of the Prow Pass Member (Lab. 158, PI In Appendix C) is a Wgh-sillca rhyolite that is typleal of the Prow Pass Member at other locations within the NTS region (Scott and Castellanos, 1984; Broxton et d., 1989b). A local zone of zeolitzantion within the same sample block (Lab." 158, 22 in Appendix $C$ ) has the same major element chemistry as the host vitric tuff; however, concentrations of moblle trace elements such as uranjum and rubldium are lower and concentrations of Sr are h/gher In the zeolltlc tuff. In contrast, concentrations of major and trace clements In the thoroughly zeolituzed tuff at the base of the section (Lab." IS7. PI In Appendix C) are similar to those found in the vitule turf.

\section{S. Hudrolonic Pronerates.}

Hydrologic propertles have not been determined for the lower part of the Prow Pass Member south of Stagecoach road.

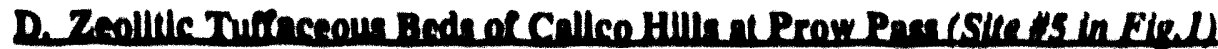

Zeolluc turfaceous beds of Callico Hills and lower Topopah Spring Member crop out at Prow Pass, at the north end of Yucca Mountaln (FIg. 11). The large number of samples (73) examined at Prow Pass provide an unique opportunity to Investjgate both vertlcal and lateral changes in mineralogy and chemistry within the continuous exposures of these zeolluc tuffs. South of Prow Pass, samples were collected from two vertical measured sectlons $0.5 \mathrm{~km}$. apart (Figs. 12 and 13) and from a lateral sample traverse that followed the north-trending strike of the tuffaceous beds of Callco Hills outcrop for a distance of one kllometer before turning eastward (Fig. 11). Addluonal samples of tuffaceous beds of Calico Hills were collected in a vertical section $0.8 \mathrm{~km}$ north of Prow Pass (Fig. 11). Petrographic data for one of the vertical sections south of Prow Pass (3.15-82- series samples) and for the vertical section 


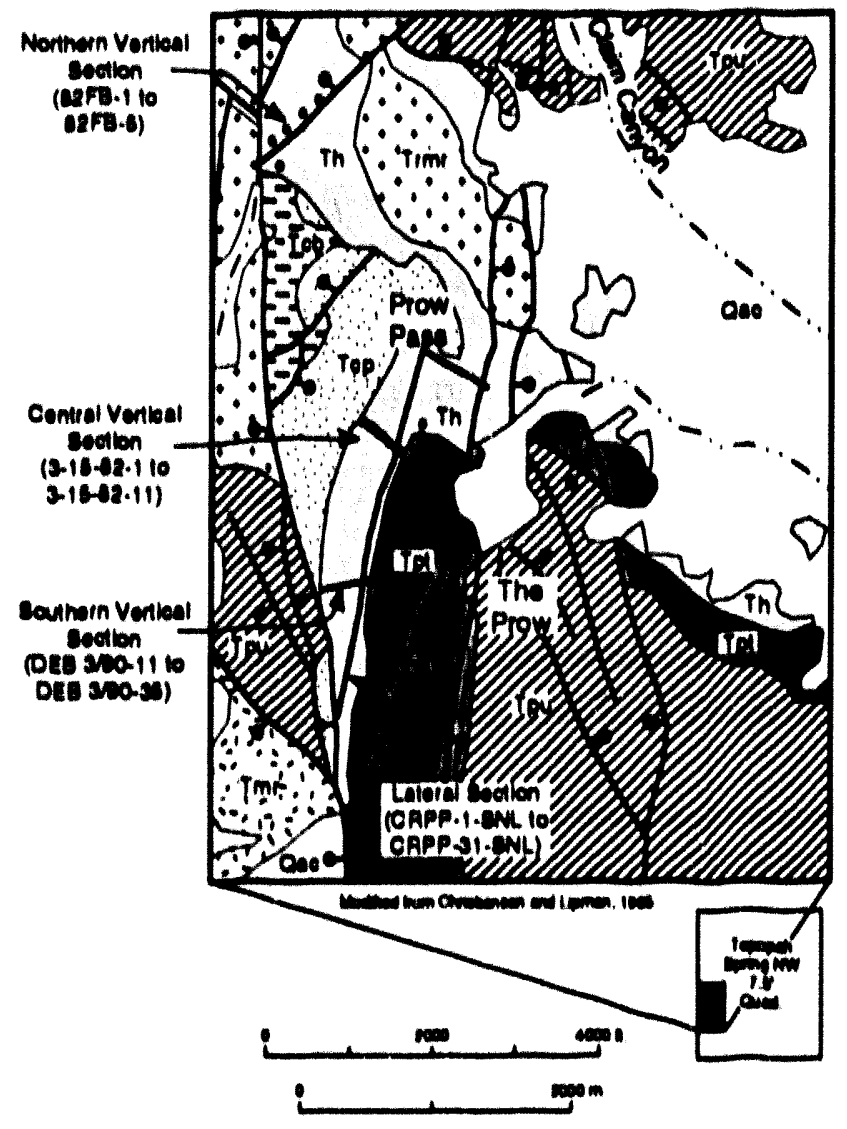

Fig. 11. Location of zoolitic tuffs sampled al ouccrops in the vicinity of Prow Pase (Site 5 in Fig. 1). Samples wore collected from the tuffeceous beds of Calloo Hills and the lower part of the Topopah Spring Member. Oeologic units shown on this figure Include: (Tcb) Bullerog Momber, (Tcp) Prow Pas Momber, (Th) luffaceous beds and lavas of Calloo Ilills, (Tpl) Topopah Spring Member, (Tpu) upper Paintbrush tuffs. (Trms) thyollte leve of Windy Wah. (Tmr) Rainier Mesa Member, and (Quc) Quacemary alluvium and colluvium. north of Prow Pass (82FB- sertes samples) are published in Broxton et al. (1989a) and are not repeated in Appendix A. Whole-rock mineralogy and chemistry for all samples from Prow Pass are given In Appendixes B and C, respectively.

\section{Wthology and Modnl Petrogerenhy} The tuffaceous beds of Callco Hills at Prow Pass are a sequence of yellow-white to pinkishtan Intercalated nonwelded ash-flow tuffs and bedded ash-fall and reworked tuffs (Fig. 12 and 13). At Prow Pass, the thickness of this unit is about $370 \mathrm{ft}$. with indlvidual tuff layers ranging from a few Inches to $65 \mathrm{ft}$. In thickness. The lower $50 \mathrm{~A}$. of this unit is relatively crystal-rich, containing 7 to 18\% phenocrysts (Appendllx A, Fig. 14a). The reminder of the unit contains less than 3\% phenocrysts, except locally where crystals accumulated in reworked tuffs. Phenocrysts throughout the unit consist of quartz, sanidine, plagioclase, and blotite. Accessory minerals Include Fe-TI oxides, allanite, apatite, and zircon.

The Topopah Spring Member overlles the tuffaceous beds of Calico Hills at Prow

Pass. The lower $20 \mathrm{f}$. of this Member is a pink nonwelded zeolitic ash-flow tuff. The nonwelded zeolltic tuffs grade abruplly upwards Into medium-gray to black moderately-welded vitrophyre, which is up to 50 n. thick at this location. Phenocrysts are sparse (0.4-1.1\% ) and consist predominately of plagloclase and sanidine (Appendix A, Flg. 14a), Quartz is present in trace amounts. Manle phenocrysts consist of blotite and trace amounts of hornblende. Accessory minerals include Fe-Ti oxides, allanite, apatite, and zircon.

\section{Mineralogy}

The tuffaceous beds of Calico Hills and the nonwelded base of the Topopah Spring Member are thoroughly altered to clinoptllollte (15-71\%), mordente (2-38\%), opal-CT (0-40\%), and smectite (0-5\%) (Appendix B, Fig. 14c). These tuffs typlcally contain 1-16\% feldspar, some of which have potassic endmember composittons (Or99.100) and represent low-temperature alteration products (Broxton et al., 1980 and 1987). Except for the basal vitrophyre of the Topopah Spring Member and for partially-welded tuffs 


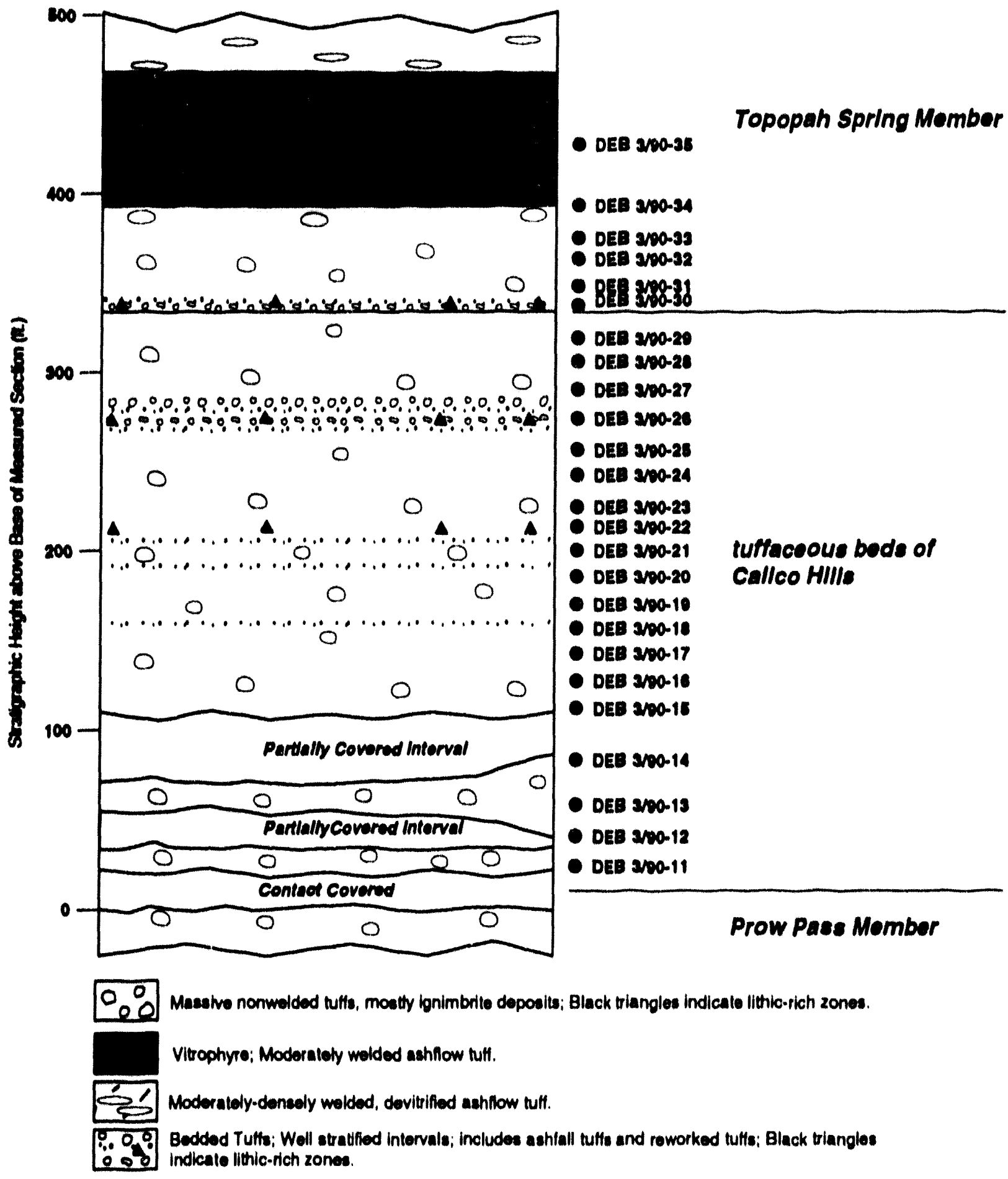

Pig. 12. Strutigraphic rection and sample locations for zeolitic tuffs in the southern part of the Prow Pass area (Site 5 in Pig. 1). 


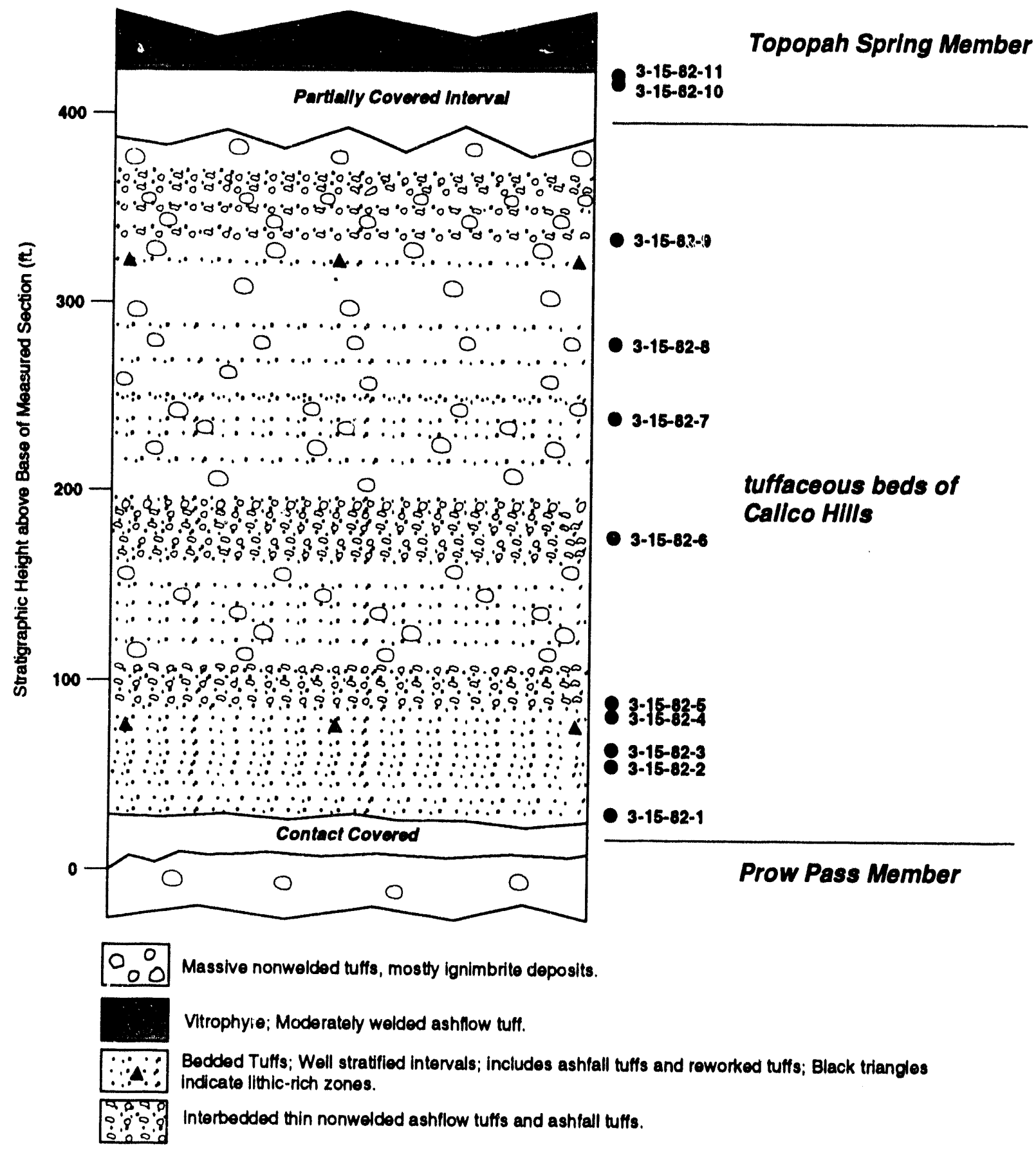

Fig. 13. Stratigraphic section and sample locations for zeolitic tuffs in the central part of the Prow Pass area (Site 5 in Fig. 1). 
immediately below the vitrophyre, all of the original volcanic glass in the nonwelded tuffs at Prow Pass was destroyed during alteration (Fig. 14c).

In vertical section, the abundance of total zeolites decreases from $70-80 \%$ at the top of zeolitic tuff sequence to $30-40 \%$ at the base of the sequence. Clinoptilolite abundances decrease down section in all three vertical sections whereas alkali feldspar, quartz, and opal-CT abundances generally increase with depth (Fig. 14c). In the lowermost part of the tuff sequence, increases in feldspar and quartz contents correlate in part with higher phenocryst abundances at the base of the tuffaceous beds of Calico Hills. However, in the central and northern vertical sections, feldspar and quartz abundances also increase with depth in the phenocryst-poor upper and middle parts of the tuff sequence; this suggests that at least part of the feldspar and quartz in these tuffs formed by secondary alteration processes.

The mineralogy of tuffs in the lateral traverse at Prow Pass does not vary appreciably except at the extreme north end where total zeolites tend to be lower and feldspar and quartz abundances tend to be higher than to the south. The decrease in zeolite abundance and increase in feldspar and quartz correlate with an increase in phenocryst content and suggest that mineralogic zonations within the tuffaceous beds of Calico Hills occur laterally as well as well as vertically. Alternatively, the lateral traverse may not follow a single stratigraphic horizon as intended but instead cuts down section into phenocryst-rich tuffs northward; If this is the case, the mineralogic zonations observed for the traverse are at least partially caused by vertical changes in mineralogy as a function of stratigraphic position.

\section{Chemistry}

The chemistry of zeolitic tuffs at Prow Pass differs substantially from the compositions of vitric tuffaceous beds of Calico Hills and lower Topopah Spring Member at Busted Butte. These zeolitic tuffs contain higher calcium (up to $3.5 \%$ ) and lower sodium (0.5-2.4\%) than the vitric tuffs, when compared on an anhydrous basis (Appendix $\mathrm{C}$ ). Potassium content is highly variable but generally tends to be higher than in the vitric tuffs. Potassium content varies antithetically with the concentration of sodium and to a lesser degree with calcium. Concentrations of mobile trace elements are also highly variable, and although there is some overlap with concentrations found in the vitr: uffs, $\mathrm{U}, \mathrm{Sr}$, and Ba contents are mostly lower in the zeolitic tuffs. Rb and Cs concentrations overlap those of the vitric tuffs, but the range of values in the zeolitic tuffs is much greater. Concentrations of immobile elements such as $\mathrm{Al}_{2} \mathrm{O}_{3}$, $\mathrm{TiO}_{2}, \mathrm{Zr}, \mathrm{Hf}$, and Th closely match those of the vitric tuffs. Water contents of the zeolitic tuffs, as inferred from LOI, decreases systematically from $11-13 \%$ at the top of the sequence to $5-8 \%$ near the base (Appendix C, Fig. 14b). The decrease in water content correlates with a decrease in total zeolites with depth.

Mobile major elements such as $\mathrm{Na}_{2} \mathrm{O}, \mathrm{K}_{2} \mathrm{O}, \mathrm{CaO}$, and $\mathrm{MgO}$ form complicated patterns of elemental enrichment or depletion with respect to vertical stratigraphic position in the measured sections. For example, calcium concentrations are greatest in the upper of the zeolitic tuffs in the southernmost 
(a)

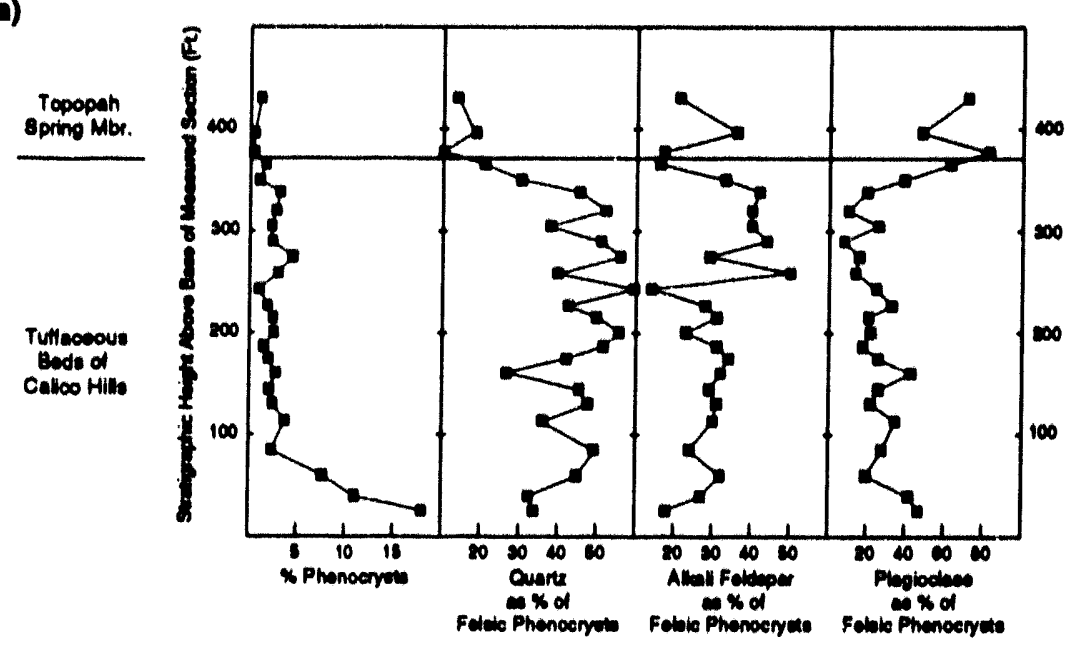

(b)

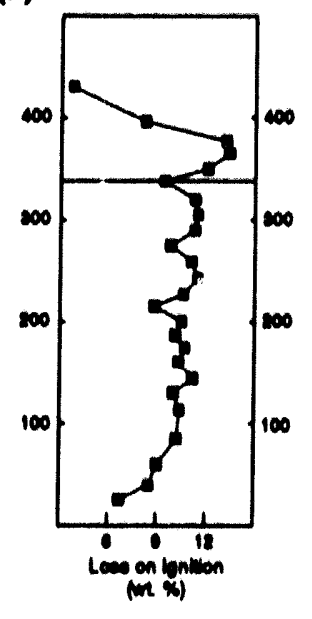

(c)

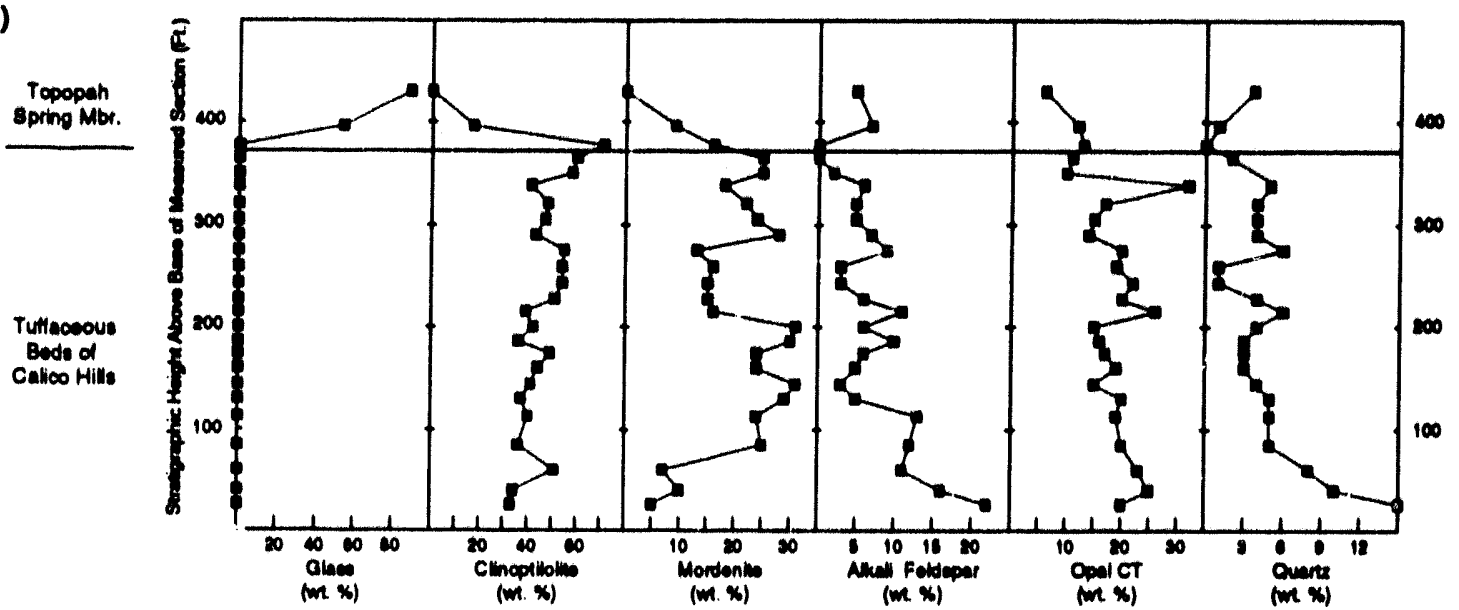

(d)

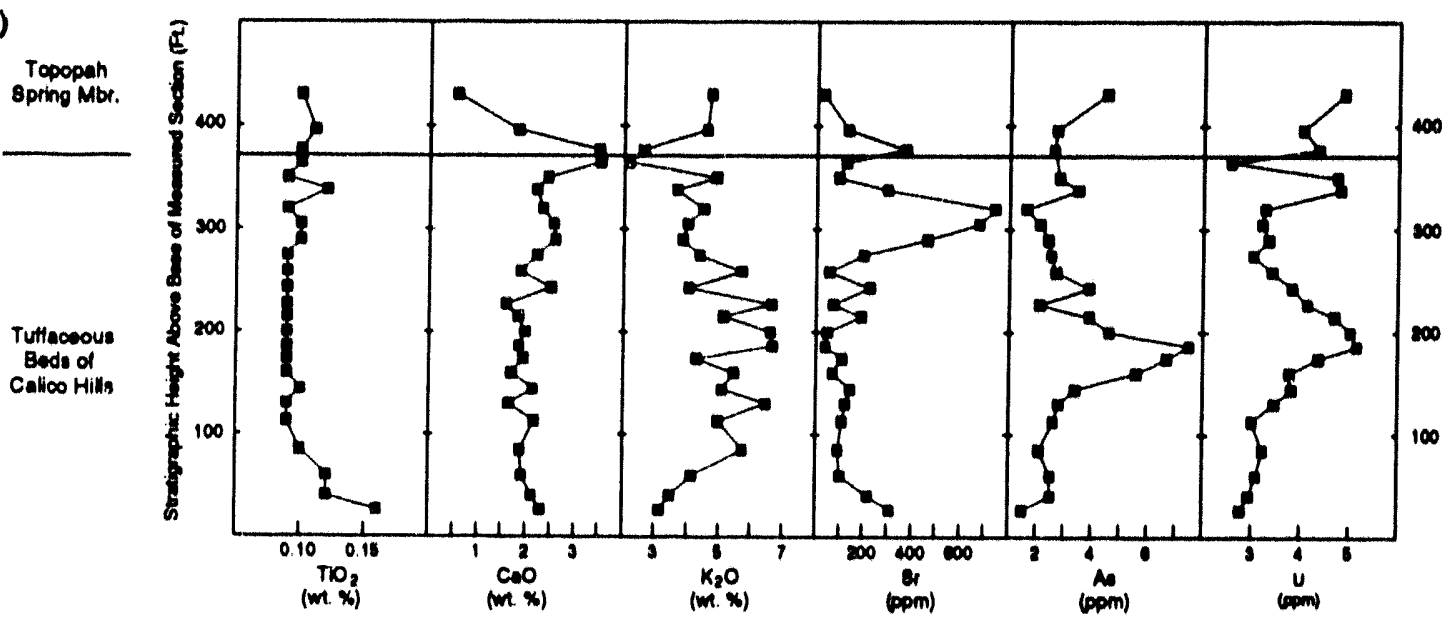

Fig. 14. Variation diagrams summarizing petrographic, mineralogic, and chemical characteristics of zeolitic tuffs sampled in the stratigraphic section at the southem end of the Prow Pass area (Site 5 in Fig. 1). Data are plotted as a function of stratigraphic position and include: a) modal petrography, b) total water contents (as loss on ignition), c) mineralogy, and d) chemistry (normalized to an anhydrous basis). 
vertical section at Prow Pass (Fig. 14d) whereas $0.5 \mathrm{~km}$ to the north calcium concentrations are greatest in the middle of the altered tuff sequence. Simllarly, the altered tuffs are most potassic in the middle of the sequence in the southernmost vertical section (Fig. 14d), and $0.5 \mathrm{~km}$ to the north the most potassic tufis are near the top and bottom of the altered tuff sequence.

Mobile trace elements also show a great deal of variability with respect to vertical position within the altered tuffs. For example, in the southernmost measured section, $U$ and As are concentrated in a well

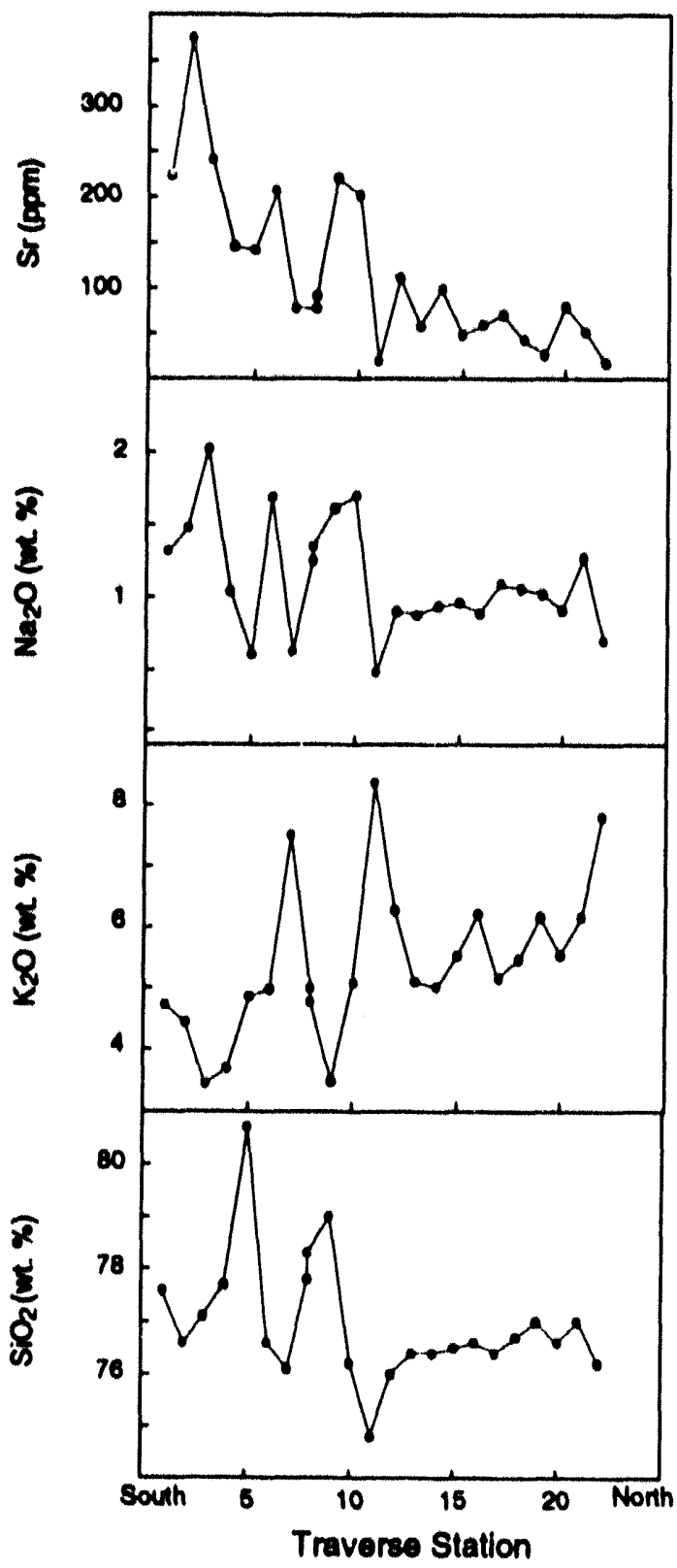

Fig. 15. Compositional variations along the lateral traverse within the tuffaceous beds of Calico Hills in the Prow Pass area (Site 5 in Fig. 1). defined zone within the central part of the tuffaceous beds of Callco Hills, and $U$ is also concentrated In an upper zone (Fig. 14d). In the same section, Sr is concentrated between the upper and lower zones of $U$ enrichment. Other mobile trace elements such as $\mathrm{Cs}$ and $\mathrm{Rb}$ show no correlation with stratigraphic position.

Although composittons are variable, tuffs in the northern part of the Prow Pass area are generally more potasslc than tuffs to the south (F/g. 15). Sillica, sodjum, and strontium concentrations are higher in the southernmost outcrops. Whereas the chemical composition of tuffs is relatively uniform in the northern part of the Prow Pass area, tuffs from the southern part of the area are characterized by highly variable chemlstry (Fig. 15).

\section{Hydrologlc Properties.}

Hydrologic properties were measured in samples from the southern vertical measured section and the lateral transect (Fig. 11). Hydrologic properties for the lateral transect are reported by Rautman (1991). Data from Rautman (1991) and from the U.S. Geological Survey/Sandla systematic sampling program for the southern vertical section are summarized in Table II and Fig. 16. The following discussion focuses on the results from the southern vertical section because the systematic sampling from this location should yield values representative of the unit as a whole. Porosity values for the zcolitic tuffs at Prow Pass range from 18 to $38 \%$ and average $27 \%$. There is a signiflcant amount of variability in porosity throughout the tuff sequence, but in general the lower part of the section has a somewhat higher porosity (mean $=30 \%)$ than the 
TABI.E II.

\section{HYDROLOGIC PROPERTIES OF THE ZEOLITIC TUFFACEOUS BEDS OF CALICO HILLS AND TOPOPAH SPRING MEMBER AT PROW PASS, YUCCA MOUNTAIN, NEVADA"}

\begin{tabular}{|c|c|c|}
\hline $\begin{array}{c}\text { Hydrologic Property } \\
\text { with Mean } \pm \text { Std. Dev. }\end{array}$ & $\begin{array}{c}\text { Southern Vertical } \\
\text { Section }{ }^{b}(n=61)\end{array}$ & Lateral Transect $b$ \\
\hline Porosity \% & $27 \pm 5$ & $33 \pm 5(n=28)$ \\
\hline Range & $18-38$ & $22-41$ \\
\hline Bulk Density $/ \mathrm{cm}^{3}$ & $1.59 \pm 0.23$ & $\mathrm{n} / \mathrm{d}$ \\
\hline Range & $1.37-1.93$ & $\mathrm{n} / \mathrm{d}$ \\
\hline Particle Density $g / \mathrm{cm}^{3}$ & $2.20 \pm 0.07$ & $\mathrm{n} / \mathrm{d}$ \\
\hline Range & $2.05-2.38$ & $\mathrm{n} / \mathrm{d}$ \\
\hline Air Permeabllityc, $\mathrm{md}^{3}$ & $\mathrm{n} / \mathrm{d}$ & $0.60 \pm 0.45(\mathrm{n}=27)$ \\
\hline Range & $\mathrm{n} / \mathrm{d}$ & $0.11-1.5$ \\
\hline
\end{tabular}
a. Sito "S in Fig. 1.
b. $\mathrm{n} / \mathrm{d}$ - not determined.
c. matrix permeability only; excludes data for fractured sample.

upper part (mean $=25 \%$ ). Bulk densities average $1.59 \mathrm{~g} / \mathrm{cm}^{3}$, and particle densitles average $2.20 \mathrm{~g} / \mathrm{cm}^{3}$. All three properties form relatively unimodal distributions (Fig. 16). The average value for porosity in the southern vertical section is similar to the value for the lateral transect (Rautman, 1991), though the lateral transect appears to be more closely related to the lower, higher porosity portion of the unit.

\section{E. Zeolitic Tuffaceous Beds of Callco Hills at Callco Hills (Site t6 in Eite 1 )}

Zeolitic tuffaceous beds of Calico Hills crop out at the type locality for this unit at Calico Hills, north of Jackass Flats. A total of 10 samples were Investigated from a single tuff bed in an east-west
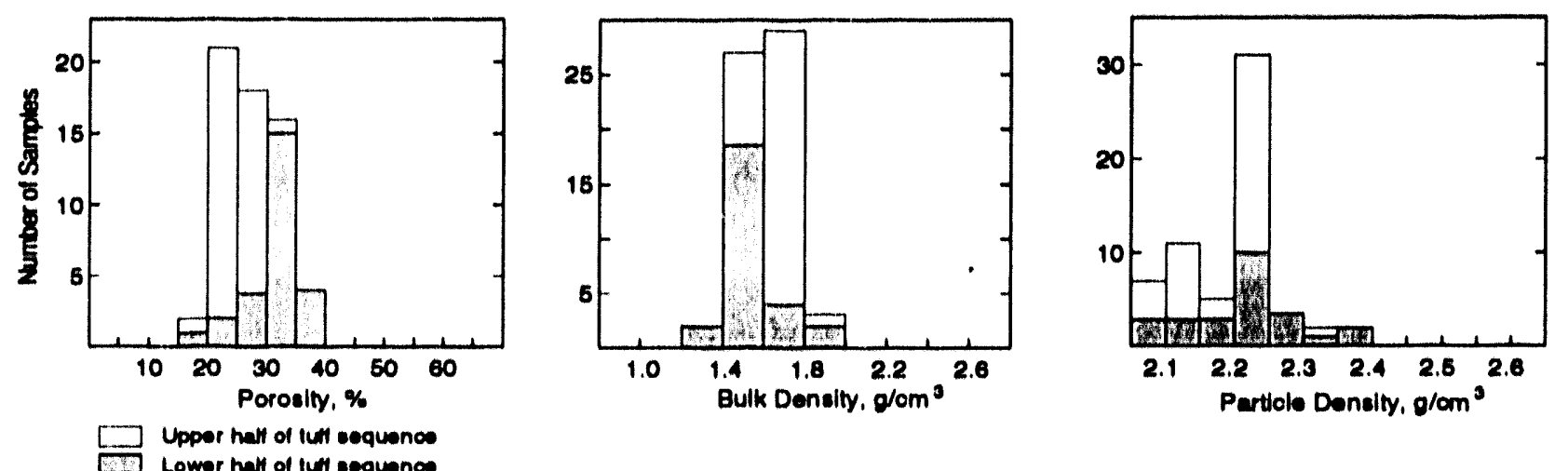

Hig. 16. Histograms of porosity, bulk density, and particle density for zeolitic tuffaceous beds of Callco Hills sampled in a vertical stratigraphic section at the southem end of the Prow Pass area (Sile 5 in Fig. 1). 


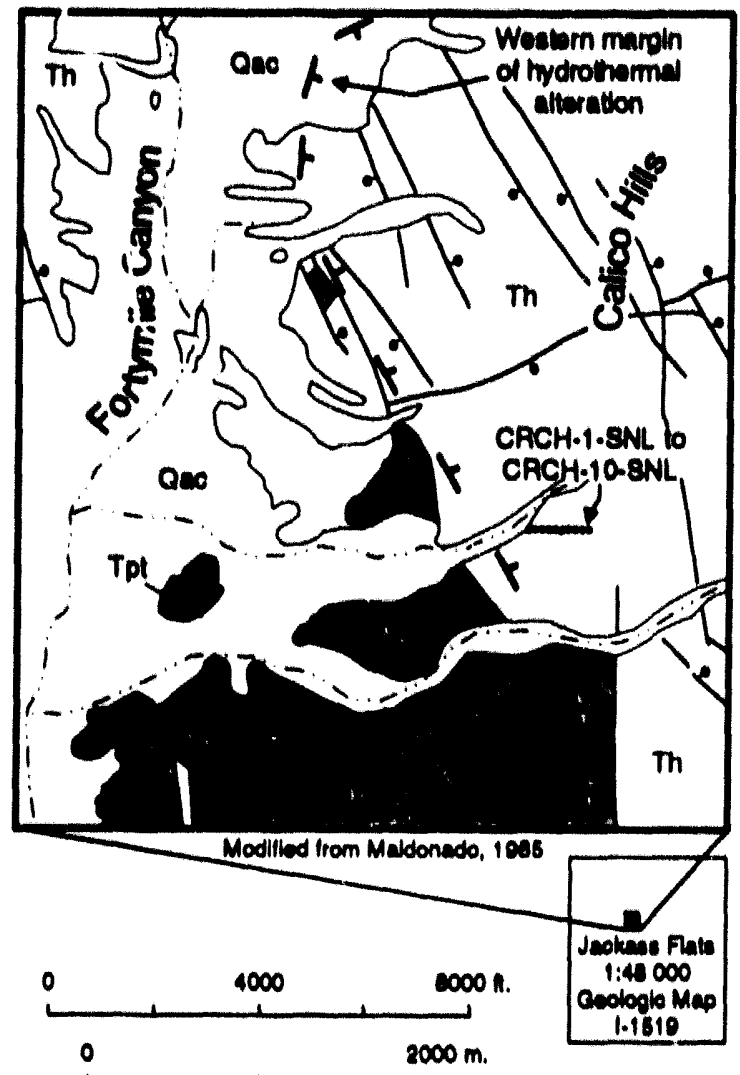

Fig. 17. Location of zeolitic tuffe sampled in a lateral traverse in the southwestern part of Calico Hills (Site 6 in Pig. 1). Samples were collected from a single abb-flow tuff within the tuffaceous beds of Calico Hills (Rautman, 1991). Geologic units shown include: ((Th) tuffaceous beds and laves of Calico Hills, (Tpt) Topopah Spring Member, and (Qac) Quatemary alluvium and colluvium. lateral traverse (Fig. 17). The $0.5 \mathrm{~km}$ long traverse follows the strike of the unit, thus the samples are not representative of the entire Calico Hills unit at this locality. Samples for this traverse were originally collected to determine the spatial variablilty of hydrologic properties in a single tuff unit (Rautman, 1991).

\section{Withology and Modal Petroeraphy.}

The tuff is a pinkish-tan to light green nonwelded Ignimbrite that is part of a tuffaccous sequence approximately 200-300 ft. thick. The tuffaceous sequence intertongues with thick lava flows to the north. The ignimbrite sampled in the lateral traverse is relatively crystal-poor ( $1-4 \%)$ with phenocrysts of quartz, sanidine, plagloclase, and blotite (Appendix A).

\section{Minernlogy.}

The tuff investigated at Calico Hills is feldspathic and zeolitic (Appendix B). Alkall feldspar, which makes up 25-67\% of the rock, is signiflcantly more abundant in this tuff than in the vitric tuffs at Busted Butte or the zeolituc tufis at Prow Pass (Fig. 18). Much of the feldspar was

deposited in vugs in the groundmass or forms overgrowths on plagloclase. Several of the alkall feldspars were analyzed by electron microprobe and are potassic end-member compositions (Or99-100). Other major alteration phases include mordenite (6-32\%), clinoptlolite (0-31\%), opal-CT (0-20\%), kaolinite (0$5 \%)$, and calcite (0-1\%). Clinoptilolite occurs only in the three easternmost samples. Small amounts of smectite were detected in only one sample.

\section{Chemistry.}

The feldspathic and zeolitic tuff at Calico Hills is significantly more potassic and less sodic than any of the other vitric or zeolitic tuffs investigated in this study, when compared on a normalized anhydrous basis (Fig. 19). Potassium concentrations range from 5.4 to $9.4 \mathrm{wt} . \%$, whereas sodlum concentrations range from 0.4 to $0.8 \mathrm{wt} . \%$ (Appendix $\mathrm{C}$ ). Concentrations of mobile trace elements are highly variable, and $\mathrm{U}, \mathrm{Sr}$, and $\mathrm{Cs}$ contents are generally lower than in the vitric tuffs at Busted Butte. Rb and $\mathrm{Ba}$ concentrations overlap those of the vitric tuffs, but the range of values is much greater in this feldspathic and zeolitic tuff. Concentrations of immobile elements such as $\mathrm{Al}_{2} \mathrm{O}_{3}, \mathrm{TiO}_{2}, \mathrm{Zr}, \mathrm{Hf}$, and $\mathrm{Th}$ 

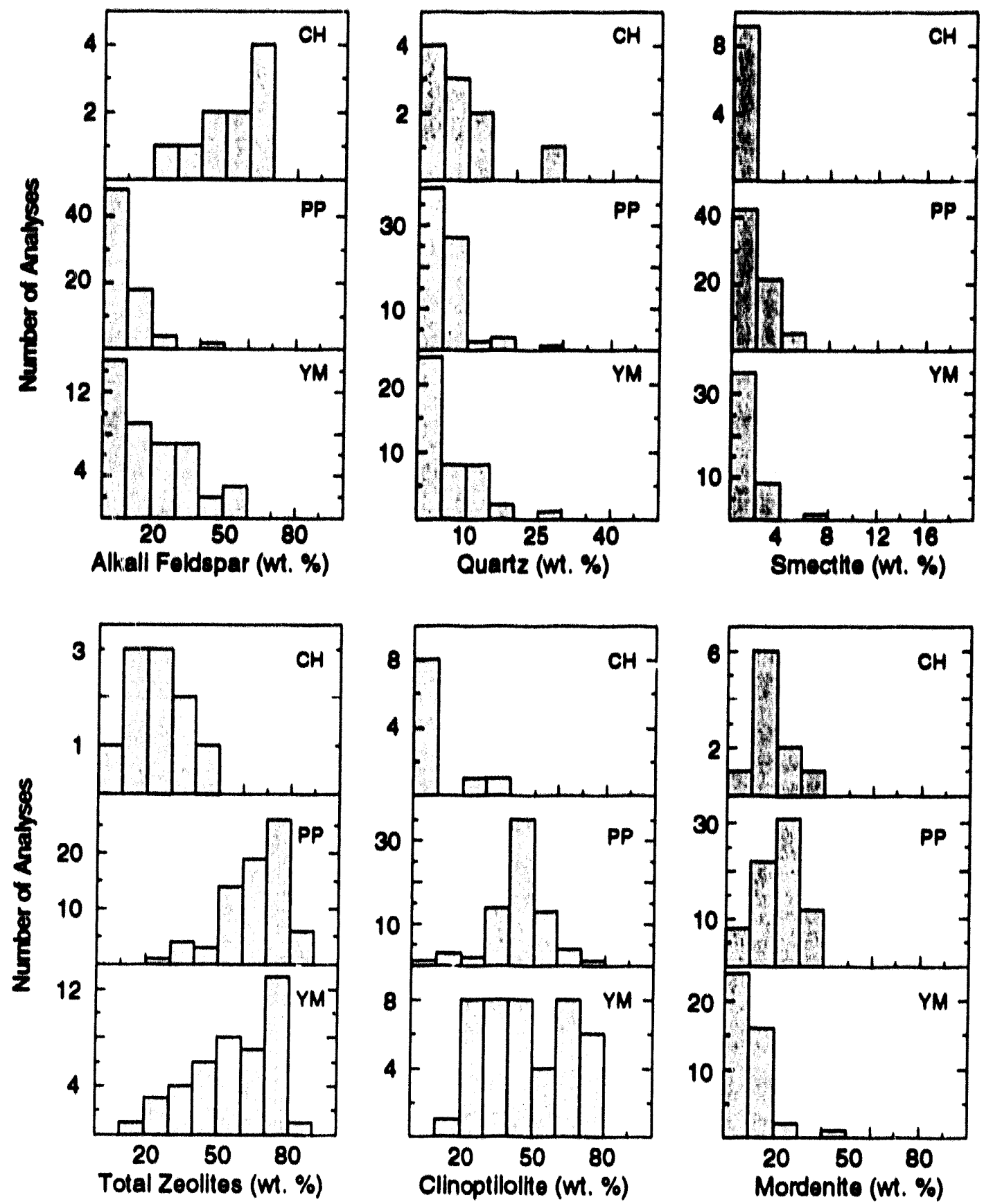

Fig. 18. Histograms comparing the mineralogy of zcolitic tuffaceous beds of Calico Hills within the exploration block at Yucca Mountain (YM) to zeolitic tuffs of the same unit at Prow Pass (PP), and Callco Hills (CH). Mineralogic data for Yucca Mountain taken from Bish and Chipera (1985).

closely match those of the phenocryst-poor portion of the vituic tuffs. No systematlc variations in chemistry occur along the traverse. Water content of the tuff $(3.2-7.1 \%)$ is generally lower than in the tuffs at Prow Pass (5-13\%), reflecting the slightly greater alteration and lower abundance of zeolites in the tuff at Calico Hills. 

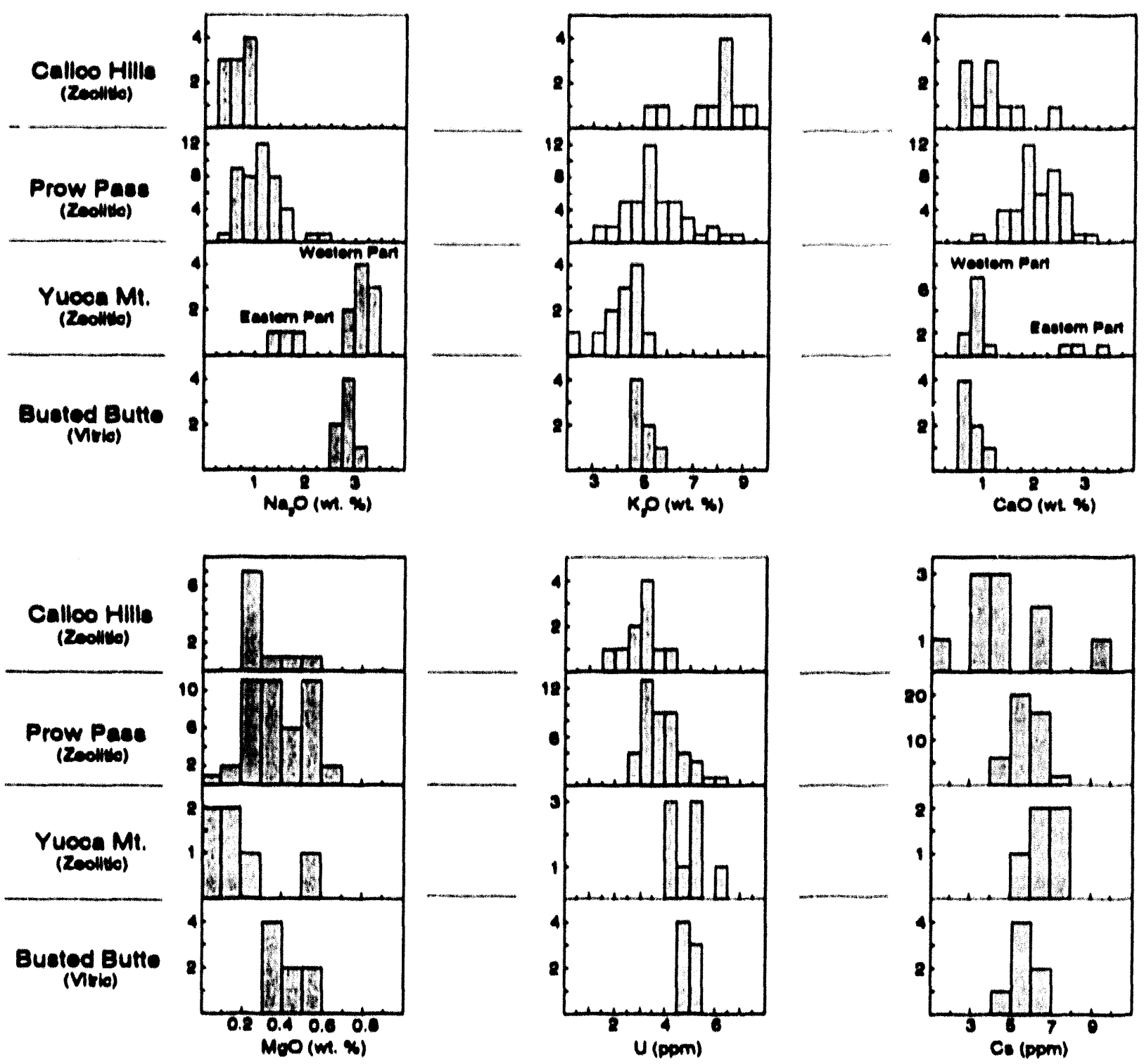

Fig. 19. Histograms comparing the chemistry of the zeolitic tuffaceous beds of Calloo Hills within the exploration block at Yuoca Mountain (YM) to the eume unit a Prow Pass (PP) and Callioo Hills (CH). Composttions of vituic tuffe at Busted Bute included to ullustrate bow open-system diagenetic alteration bas mobilized and re-arranged the chemical consutuents of the 2colitic tuffe. Ondy tuffe contaning loes than $4 \%$ pbenocryats are included so that chemical variations due to rolative phonocryat abundancas ase minimized. Chemical data for Yucca Mountain taken from Broxton et al. (1986). All olemental concentrations ave normalizad to an anhydrous basis.

\section{Hydrolosic Propertias.}

Hydrologic propertles of the tuff at Calico Hills are reported by Rautman (1991) and are summarized in Table III and Fig. 20. Porosity values range from 23 to 38\% and average 29\%. Bulk densities for these altered tuffs range from 1.55 to $1.89 \mathrm{~g} / \mathrm{cm}^{3}$ and average $1.72 \mathrm{~g} / \mathrm{cm}^{3}$. Permeabillties to alr average $0.57 \mathrm{md}$. None of the hydrologic propertles show systematic changes along strike. 

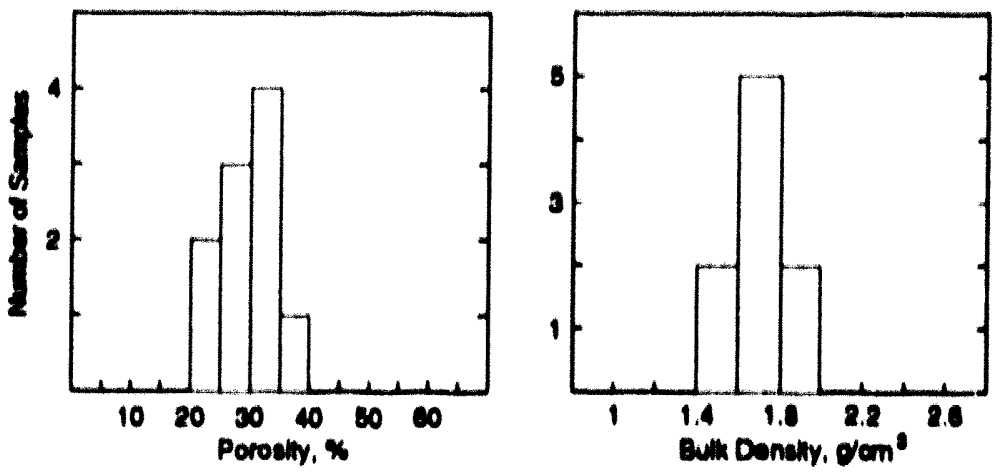

Mis. 20. Ilistograms of porosily and bulk denally for zeolitic tuffaceou bads of Calico Hills sampled in a laterd trovene al Calico Hillis (Sito 6 in Pis. 1). Duta from Reutman (1991).

\section{DISCUSSION}

The tuffaceous beds of Callco

Hills in the vicinity of the potentid repository are sequence of stratifled tuffs comprised of Intercalated nonwelded ash-flow tuffe, bedded ash-fall, and reworked tums. These tuffes are high-sllica thyolites and form a compositiona continuum with the overlying rhyolluc tufres of the Topopan

Spring Member (Broxton et al., 1989b; this report). The nonwelded tufrs of the Callco Hille und and the nonwelded tuffs in the lowermost part of the Topopah Spring Member have similar thermal and mechanical properties and together comprise the thermal-mechandeal unit CHn of Ortz et al. (1985). Whole-rock mineralogic propertles of this tuff interval vary across the exploration block, and the therma. mechanical unl is further subdivided into CHnv for vituic tuffs and CHnz for zeolluc turfs. The dites Investgated for a surface-based test facillty were selected for study because they belong to the same stratlgraphic sequence as $\mathrm{CHnv}$ or $\mathrm{CHnz}$, or because the sites contain rocks that are similer to one or both of these two thermal-mechanjcal unlts.

The hydrologic properties of the tuffaceous beds of Callco Hills in the vicinity of the potendal repository have been summarized by Filnt and Filnt (1990). These data are summartzed in Table IV and Fig. 21. Although these data represent geographically distributed samples, they do not represent unblased sampling of the unit as a whole. For comparison, a more systematlc sampling of the vituic tuffe of Calico Hills just south of the potential repository was conducted using core from drill hole USW QU-3. The

TABLE III.

HYDROI.OGIC PROPERTIES OF THE ZEOLITIC TUFFACEOUS BEDS OF CALICO HILLSS AT CALICO HIL.L.S, YUCCA MOUNTAIN, NEVADA*

a. Sito 16 in Pig. 1.

\begin{tabular}{|c|c|}
\hline $\begin{array}{c}\text { Hydrologic Property } \\
\text { with Mean } \pm \text { Std. Dev. }\end{array}$ & $\begin{array}{c}\text { Lateral Transect } \\
(n=10)\end{array}$ \\
\hline Porosity \% & $29 \pm 5$ \\
\hline Range & $23 \cdot 38$ \\
\hline Alr Permeabllity, md & $0.57 \pm 0.35$ \\
\hline Range & $0.073 \cdot 1.2$ \\
\hline
\end{tabular}


TABLEIV.

HYDROL.OOIC PROPERTIES OF THE TUFFACEOUS BEDS OF CALICO HILLSS IN THF VICINITY OF THE POTENTIAL REPOSITORY, YUCCA MOUNTAIN, NEVADA ^

\begin{tabular}{|c|c|c|c|}
\hline $\begin{array}{l}\text { Hydrologlc Property } \\
\text { with Mean } \pm \text { Std. Dev. }\end{array}$ & $\begin{array}{l}\text { Callco Hills } \\
\text { vitulc tumb }\end{array}$ & $\begin{array}{c}\text { Vitric Turrs at } \\
\text { Drill Hole USW OU.3e }\end{array}$ & $\begin{array}{l}\text { Callco Hills } \\
\text { zeolluc tumb }\end{array}$ \\
\hline Poroally \% & 33 & $35 \pm 9$ & 28 \\
\hline Renre & $27 \cdot 39$ & 10.51 & $14 \cdot 36$ \\
\hline Bulk Denslly $/ \mathrm{cm}^{3}$ & 1.67 & $1.51 \pm 0.24$ & 1.62 \\
\hline Ranre & na & $1.05 \cdot 2.13$ & $1.44 \cdot 1.87$ \\
\hline Permeabllily to Water, md & 0.63 & Ndd & 0.015 \\
\hline Range & $0.01 \cdot 1.7(47)^{d}$ & $\mathbf{n} / \mathbf{d}$ & $0 \cdot 0.07(9.9)^{d}$ \\
\hline
\end{tabular}

a. Ne - not epplleable, only one semple reported; $n / d$ - not determined.

b. oxerested from Fint and Fint (1990); atanderd deviation not compuled.

c. dach colleotad by A.L. Fint and C. A. Reutman, wee Yuces Mountain Projest (1992).

d. parentbotiod value reprocents aingle extreme value not included in mean.

results, which should be more representalve stadsatically of the vitrle materia within the Callco Hills unll, se also presented in Table IV for comparison with the smaller vitric dats set of Filnt and Filnt (1990).

The hydrologic, geochemical, and mechanical properties within the tuffaceous beds of Calico Hills in the vicinity of the potentlal repository are spatlally varlable. For instunce, on the castern side of the exploration block the tuffaceous beds of Callco Hills consist of nonwelded zeolluc turfs that are
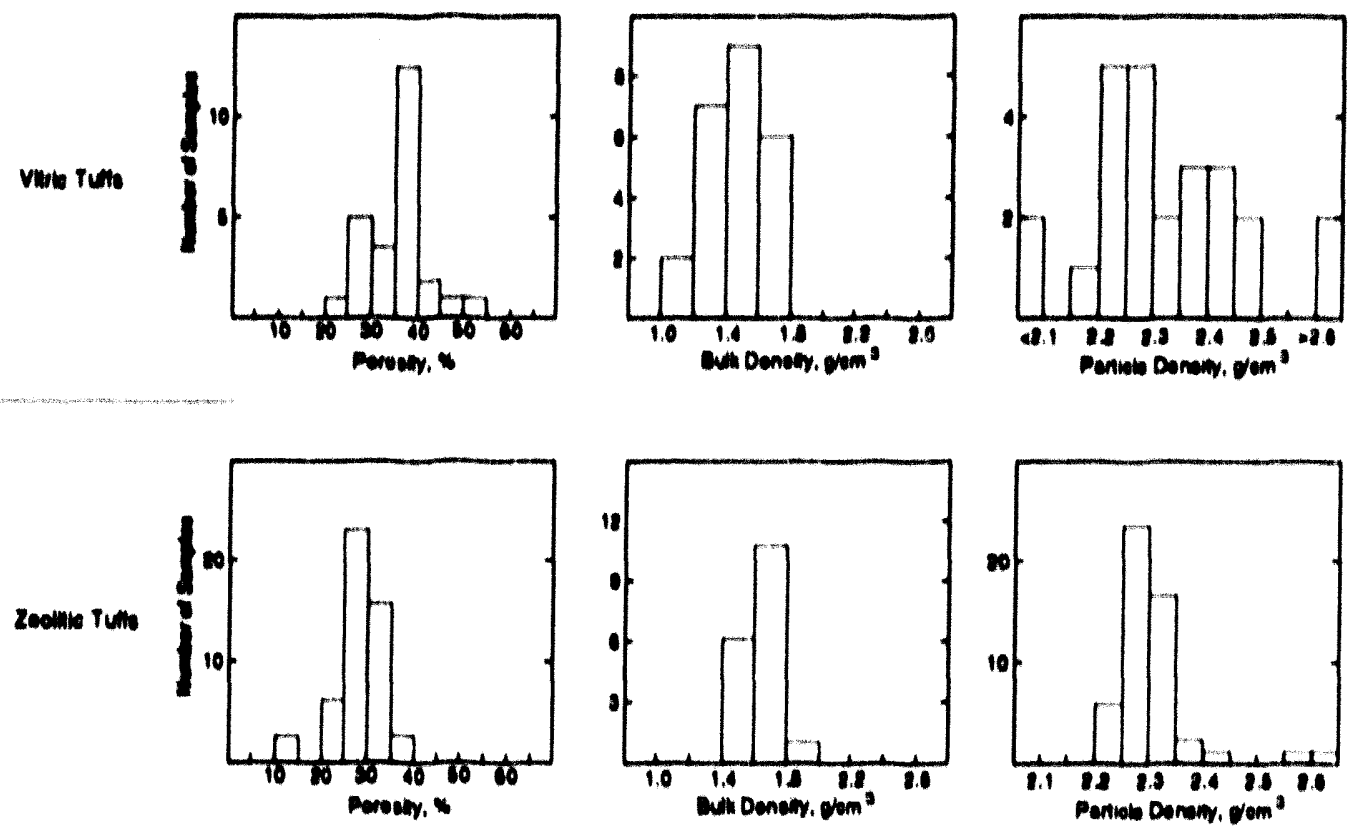

Hig. 21. Histograni of porosity, bulk density, and particle density for vitite tuffaceous beds of Calico Ilills in the exploration block (represented by date for drill bole USW OU,3) and for zeolitic tuffo of the sune unil in the exploratlon block (represented

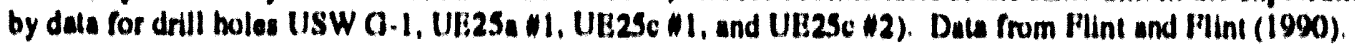


relatively Impermeable to water movement, highly sorptive of cattonle radionuclldes, and strongly Indurated. These rocks are supplanied westward by vitulc tuffs that are very similar in bedding and welding characteristles but are relatively unaltered when compered to tums on the eati. The vitulc tuff in the weat have high permeabillity to water movement, are leas sorptlve of cationic radionuclides, and are poorly Indurated.

A surface-based teat facility dealgned to accass rocks similar to those that make up the turfaceous heds of Calico Hills within the exploration block could be alted In elther vitric of zeolltic nonweldad ash. now and bedded turfs, based on the characteristlcs described above. Selectlon between a vilute and zeolltic host rock will be governed largely by lesting requirements of investlgators who will use the facillty. The following discusalon compares data collected for the sltes exumined in this study to similer data for the luffaceous beds of Calleo Hills within the exploradion block. A preliminary evaluation of the sultability of these sltes to host a surface-based teat facillity is made based on the similarity of the rocks at the sites to the iwo principul rock lithologles (vitutc and zeolluc) found within the exploration block.

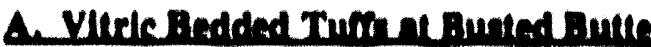

The vitulc bedded tuffs exposed a Busted Butte and the vitulc facles of the luffeceous beds of Callco Hills within the exploratjon block (thermal-mechanleal unil CHnv) a Yucca Mountaln are almilar Ilthology, mineralogy, and chemiatry. Excepe for the Inclualon of the Wahmonje Formation, the stratigraphlc auccession at Busted Butte (Figs. 3 and 9) matches the stratlgraphic units that make up thermal-mechanjcal unli CHnv at Yucca Mounialn. In both locations, the tuffa consiat of Intercalated an. now tuffs and bedded ash-fall and reworked tuffs. Well-developed stratincation and Iack of welding characterize tufis in both locations. The vitric tufrs a Busted Butte are thinner (a maximum of $125 \mathrm{n}$. thick from the inp of the Prow Pass Member to the basd vituophyre of the Topopan Spring Member) than unil CHnv af Yucca Mountain (-332 ก. In USW QU.3), but there is ample stratigraphic thickneas to alte a horliontal adl at Busted Butte, particularly at the north end.

The chemistry and mineralogy of the vitule tuffs at Busted Butte are very similar to equivalent luff's at Yucca Mountaln. The tuffs in both locatjons are high-sllica thyolltes, and except for zcolluzation localized along the fault at the north end of Busted Butte, have undergone only minor chemlcal and mineralogic alteration. The Wahmonic Formation is made up of dacltes that contaln significantly more mafle phenocrysts and accessory minerals than the rhyolites that lle above and below. Invesugators planning experiments involving rock-water Interactions, partlcularly for radjonuclide migration studies, should be aware that the unique chemical characteristlcs of this tuff may be asignincant variable if teats are sited in this unit. I.Jthologle propeitles of the Wahmonie Formation are very similar to those of unit CHnv at Yucca Mountain. Hydrologic properties have not been determined for the nonwelded vitulc turfs at Busted Bulte. 


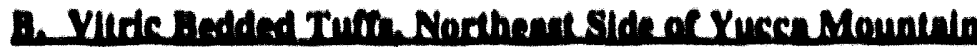

Nonwelded turfs between the Topopah Spring and Yucca Mountain Members at the northeast side of Yucca Mountain Include 1) the zeolitic lapllil tuff and ash. now tuff at the base of the Pah Canyon Member and 2) vitulc an- fow and bedded tuffs that make up the lop of the Pah Canyon Member and the overlying sequence of bedded tufm (Fle. 7). These nonwelded teolltic and vitulc turfs are similar luffs that make up thermal-mechanical units CHns, and CHnv, reapectlvely, al Yucca Mountaln.

Although comprised of different stratlgraphlc undts, the zeollte turfs at northeautern Yucca Mountain have almilar lithologic churacteriatles to CHna at Yucca Mountaln. The major lithologle difrerence between the turfi at these Iwo locations is the presence of only one depositional break in the zeolluc turrs at northeas Yucca Mountaln whereas the tuffaceous beds of Calleo Hills Iypleally contalns numerous depoultional breaks. The straufication reaulung from the presence of numerous deposituonal breaks may afrect the hydrologle properjes of the lufreceous beds of Callec Hills. Juxtaposalion of unils with contrasung eraln slzes across deposituon boundurlet cen affect permeahilliy pathways dong which water movea through the tuff. Avallable hydrologle data suggeat that the turreceous beds of Callen Hills are sllghtly leas porous and have a lower bulk denally than the zeollite tums at the base of the Pah Canyon Member (compere Figs. 9 and 21). Inveatlgators who Intend to Inveatlgate water movement in zealluc tufrs should ake Into account the generd lack of atratincauton in the zeollitc tuffr at this location. The zeolluc lufrs at northesul Yucca Mountaln are -60$) \cap$. thick.

The mineralogy of zeolite cufrs al northeas Yucca Mountaln is very similar to that found in the fuffaceous beds of Calleo Hills al Yuces Mountaln, but there are some slgnincant differences in chemistry. Both tuffe are altered to an suemblage of climopdlolite and subordinate amounts of mordenite. However, the zeolluc tuffe (and presumably the zeolites themselves) at northeast Yucca Mountain are much more calcic than the zeolite tufraceous beds of Calico Hills al western Yucca Mountun (Fig. 19). Calclum-rich zeolltes can strongly uffect the expanalon/contraction, hydration/dehydration, and lon-exchange propertles of tuff (Bish, 1984 and 1985; Ames, 1966); Vaughan, 1978). Thus, the difference In chemistry between this outcrop location and the tufraceous beds of Calleo Hills is a variable that should be ovaluated in any plannod iests.

Viteric tuffs at the top of the section at northeast Yucce Mountain closely match the lithology of vituic tuffaceous beds of Calleo Hills within the exploratlon block. Vitric tuffs at both locations consist of Intercalated nonwelded ah-now turfs and bedded ash. fall and reworked turfs. Stratiflcation is well developed a both locations because of the presence of numerous Individual deprositional units. Although pert of thermal-mechanical unit PTn, the llthologle properties of the vituic luffs al northeast Yucca Mountaln are very simllar to those of thermal-mechanical unil CHnv within the exploration block. The vitulc tuffe at northeast Yucca Mountain are $~ 170$ n. thick.

In general, the chemistry and mineralogy of the vitutc tuffs at northeustern Yucca Mountain are very almilar to that found in the vitric tuffaceous beds of Calleo Hills within the exploratton block. Both 
luff requences are thyolltes, which have undergone little dlagenetic alteration, and hydrated glasay pyroclasts are their primary mineralogical consutuents. Although the chemistry of turfs in both locations Is similar, the Pah Canyon Member and the rhyolite of Dellitum Canyon of the bedded tuff sequence are not as highly evolved as the Wigh-allica rhyollte of the tufraceous beds of Calico Hills. Differences in chemiatry between these tums are relatively minor for major elements but are greater for trace elements. When considering the lower pan of the vitrle bedded tuffs at northeast Yucca Mountain for a surfacebased teat facilliy, Investlgators should evaluate whether these chemical differences could have an effect on their experiments. The thyolite of Black Glass Canyon, which makes up the greater part of the bedded turf sequence above the Pah Canyon Member, is a h/gh-allica thyolite that is very similar in major. and trace-element chemistry to the tuffeceous beds of Calico Hills.

Hydrologic propertles of the vitulc bedded tuffs above the Pah Canyon Member appear quile simlar to those of the vitric lufraceous beds of Callco Hills a USW OU.3 (compare Tables I and IV and Figs. 9 and 21). Porositles are between 35 and $40 \%$ at both locations. The bedded turfe at northeast Yucca Mountan are allghuy more porous than the more widaly-dlstributed but potentally-blased data of Filnt and Filni (1990), Bulk densitues of the vilutic bedded tuffs are similar to values for USW OU-3 and from Fint and Filnt (1990), and are disunct from the morc welded portions of the Pah Canyon Member at this location and from zeolluc tuffs clsewhere. These upper furfs appear to be good analogs to the vitric turfaceus beds of Callco Hills within the exploration block.

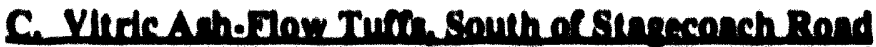

The viturc turrs in the lower part of the Prow Pass Member are generally almilar In lithology to the nonwelded ash.flow turfs commonly found in the tuffaceous beds of Callco Hills at Yucca Mountain. The major lithologic difference betwcen these two turfs is that Prow Pass turfs south of Sugeconch Road are comprised of a single ash. now tuff whereas the turfaceous beds of Callco Hills typlcally contaln numerous depositional units separated by prominent strat graphlc breaks. Hydrologic propertles have not been determined on samples from the Stagecoach Road localliy. However, the lack of stratification within the tuffs at Stagecoach Road probably means that the hydrologic propertles of these tuffs differ substantially from the tuffaccous beds of Callco Hills w/thin the exploratton block.

The degree of alteration found in the vitulc tuffs at Stagecoach Road preclude them from being selected as host rocks for a surface-based test facility in vitric tuff. Diagenetic alteration of vituic turfs at Siagecoach Road outcrops is more extenslve than what is usually found in the vitutc tufraceous beds of Calico Hills within the exploration block. The vituic tufrs in the lower part of the Prow Pass Member contaln numerous local zones of zeolitzation and the base of the unit is thoroughly zeolluzed. Alteration Is unevenly distributed throughout the vitulc zone and probably results in nonuniform hydrologic and gexchemical properties over the scale of any proposed experiments in a surface-based test facillity. 


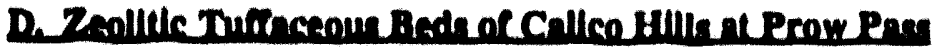

The Uthology of zeolltuc tuffaceous beds of Calico Hills and lower Topopah Spring Member at Prow Pass (Figs. 12 and 13) closely matches that of equivalent units within the exploration block. Tufrs at both locations consist of well-strau ned, Intercalated, nonwelded ash-now tuffs and bedded ash-fall and reworked turfs. The zeolltic turfs at Prow Pass are laterally equivalent to thermal-mechanical unit CHnz. a Yucca Mountain. The section of zeolituc turfs at Prow Pass is relatively thick $(-390 \mathrm{n}$.) and well exposed.

The chemistry of the zeolltic tufrs at Prow Pass differs substantially from the zeolite turfs at Yucca Mountaln. Concentrations of moblle exchangeable cattons such as $\mathrm{K}_{2} \mathrm{O}, \mathrm{CaO}$, and $\mathrm{MgO}$ are strongly enrlched and $\mathrm{Na}_{2} \mathrm{O}, \mathrm{U}$, and $\mathrm{Cs}$ are depleted in the zeollte tuffs Prow Pass relative to equivaleri tuffs at Yucca Mountain (Fig. 19). Desplte these differences In chemistry, the mineralogy of tuffs at buin locations is very similar. Both tuff sequences are thoroughly altered to an assemblage of clinuptllolite and mordenite and total zeollte abundances are about the same (Fig. 19). Clinopulollte is the dominant alteration product at both locations although mordentte abundances are somewhat higher at Prow Pass (Fig. 18). The difrerences in chemistry and mineralogy between tuffs at Prow Pass and at Yucca Mountain probably have little efrect on the hydrologic and mechanical propertles of the tuffs. Indeed, the average bulk hydrologic propertles in T bles II and IV are very similar. The average porosittes are 27 and 28\% respectively, and the average bulk density of both is $1.6 \mathrm{~g} / \mathrm{cm}^{3}$. The range of values for these parameters is similar as well, which could be equally informative, given the nonsystematic data in Table IV. However, differences in chemistry and mineralogy should be carefully cvalualed by investigators because these factors could have a significant effect on experiments involving rock-water interactlons.

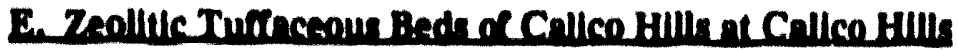

The lithology of zeolituc tuffs at Calico Hills is similar to that of equivalent units within the exploration block. Although the lateral section at Calico Hills sampled only one ash-now unit, this ashnow unit is part of a stratined sequence that includes intercalated nonwelded ash-now tuffs and bedded tuffs that are very similar to those found at Yucca Mountain. The zeolitic tuffs at Calico Hills are strat graphically equivalent to thermal-mechanical unit CHnz at Yucca Mountaln. The section of zeolitic tuffs at Calico Hills is relatively thick (20()-3(X) $\mathrm{f}$.) and well exposed.

L.jke at Prow Pass, the chemistry of the zeolituc tuffs at Calico Hills differs substantially from the zeolituc tuffs at Yucca Mountain. Concentrations of $\mathrm{K}_{2} \mathrm{O}$ and $\mathrm{MgO}_{8}$ are strongly enriched in the zeolltic tuffs at Prow Pass relatlve to equivalent tuffs at Yucca Mountaln whereas $\mathrm{Na}_{2} \mathrm{O}, \mathrm{U}$, and Cs are depleted (Fig. 19). Unlike at Prow Pass, the mincralogy of tuffs also differs substantially when compared to tuffs a Yucca Mountain. Al Calleo Hills, the alteration assemblage primarily consists of authigenic potassium feldspar and mordenite (Fig. 18). Clinopulolite was detected in only three of the ten samples examined. 
Because of greater authigenic potassium feldspar crystallization, total ceolite abundances are much lower for the tuffs at Calico Hills (<50\%) than for similar tuffs at Yucca Mountain (Fig. 18). Because of the magnitude of chemical and mineralogic differences between tuffs at Calico Hills and at Yucca Mountain, there also may be substantial differences in mechanical properties between the two tuff sequences. Differences in hydrologic properties are difficult to judge because of the limited and potentially nonrepresentative sampling at Calico Hills. The average porosity of $29 \%$ for the sampled unit at Calico Hills (Table III) is very similar to $28 \%$ for the potential repository area (Table IV) and $27 \%$ for the southern vertical section of the Calico Hills unit at Prow Pass (Table II), suggesting the differences in the bulk hydrologic properties may not be extremes. However, investigators planning experiments involving rockwatcr interactions should be particularly aware of the large chemical and mineralogic differences between the two sites.

\section{RECOMMENDATIONS}

A ranking of the sites investigated in this study to host a surface-based test facility is given in Table V. Each site was evaluated for its similarity to the geologic setting of the tuffaceous beds of Calico Hills at Yucca Mountain. The evaluation is based on how well the sites hivestigated mimic the lithologic, mineralogic, and chemical conditions of the vitric and zeolitic tuffs that make up the Calico Hills unit within the exploration block. The grading of rock characteristics for each site is based on the discussions above. All characteristics received equal weighting in the evaluation; it might be appropriate to re-grade these sites at some time in the future after assigning higher weighting factors to rock characteristics of particular interest, such as lithology or mineralogy for example, if the suite of tests developed for the surface-based test facility emphasize mechanical or hydrologic properties of the tuff over rock/water interactions. The evaluation does not take into account hydrologic properties, because these types of data are not available for all of the sites investigated.

The vitric tuffs most closely approximating the geologic properties of the tuffaceous beds of Calico Hills within the exploration block are 1) those at Busted Butte and 2) those in the upper part of the Pah Canyon Member and the overlying bedded tuff sequence at northeast Yucca Mountain. Tuffs at both locations are excellent analogs to the tuffs at Yucca Mountain and each received 11 out of a possible 12 points (Table V). Both locations were rated excellent in the categories of lithology and mineralogy and were rated good in the category of chemistry. Chemistry was graded no higher than good because both locations contain some tuffs that are less chemically-evolved than the high-silica rhyolites of the tuffaceous beds of Calico Hills. These less-evolved tuffs are found in the lower parts of both sections, whereas tuffs with compositions more typical of the tuffaceous beds of Calico Hills beneath the exploration block are found in the upper part of the sections. Presumably, a surface-based test facility would be sited in the upper parts of these tuff sequences if rock chemistry is identified as an important variable in the tests to be performed. 
TABLE V.

RANKING OF VITRIC AND ZEOLITIC TUFF SITES TO HOST A SURFACE-BASED TEST

FACILITY, YUCCA MOUNTAIN, NEVADA

\begin{tabular}{|c|c|c|c|c|c|}
\hline & \multicolumn{4}{|c|}{ Degree of Similarity to Tuffs at Yucca Mountain } \\
\hline & & $1=$ Poor & 2 = Fair & $3=$ Good & $4=$ Excellent \\
\hline $\begin{array}{l}\text { Site } \\
\text { (Site \# in Fig. I) }\end{array}$ & $\begin{array}{l}\text { Vitric (V) or } \\
\text { Zeolitic (Z) }\end{array}$ & Lithology & Chemistry & Mineralogy & $\begin{array}{c}\text { Total Score } \\
\text { (out of 12) }\end{array}$ \\
\hline $\begin{array}{l}\text { Busted Butte } \\
\text { (Site \#I) }\end{array}$ & $\mathbf{V}$ & 4 & 3 & 4 & 11 \\
\hline $\begin{array}{l}\text { NE Yucca Mt. } \\
\text { (Site \#2) }\end{array}$ & V & 4 & 3 & 4 & 11 \\
\hline $\begin{array}{l}\text { Stagecoach Rd. } \\
\text { (Site \#3) }\end{array}$ & $\mathrm{V}$ & 2 & 3 & 1 & 6 \\
\hline $\begin{array}{l}\text { NE Yucca Mt. } \\
\text { (Site "4) }\end{array}$ & $\mathbf{Z}$ & 2 & 2 & 4 & 8 \\
\hline $\begin{array}{l}\text { Prow Pass } \\
\text { (Site "5) }\end{array}$ & $\mathbf{Z}$ & 4 & 2 & 3 & 9 \\
\hline $\begin{array}{l}\text { Calico Hills } \\
\text { (Site }\end{array}$ & $\mathbf{Z}$ & 3 & 1 & 1 & 5 \\
\hline
\end{tabular}

The zeolitic tuffs most similar to the zeolitic facies of the tuffaceous beds of Calico Hills at Yucca Mountain are 1) those at Prow Pass and 2) those in the lower part of the Pah Canyon Member at northeast Yucca Mountain. Zeolitic tuffs at both locations are very similar to the tuffs at Yucca Mountain and received 8 to 9 points out of a possible 12 points (Table V). The Prow Pass site received good to excellent marks for lithology and mineralogy, but only a fair rating for chemistry. The fair rating in chemistry reflects the potassic chemistry of tuffs at Prow Pass relative to Yucca Mountain. The tuffs in the lower part of the Pah Canyon Member received an excellent rating for mineralogy, but only fair marks for lithology and chemistry. Lithology was graded as fair because the Pah Canyon is a single massive ash-flow tuff and lacks the stratification that results from the deposition of numerous individual tuff units; such well-stratified bedded tuffs are typical of the tuffaceous beds of Calico Hills. The fair rating in chemistry reflects the unique calcic chemistry of tuffs at Prow Pass relative to Yucca Mountain.

\section{CONCLUSIONS}

Outcrops of nonwelded vitric and zeolitic tuffs in the vicinity of Yucca Mountain were examined as possible locations for a surface-based prototype test facility for the Yucca Mountain Project. In this 
report, emphasis is placed on examining sites with rocks similar to the tuffaceous beds of Callco Hills, an Important geologic and hydrologic bartier between the potential repository and the water table. The tuffaceous beds of Calico Hills within the exploration block are made up of both vitric and zeolitic tuffs whose mineralogic, chemical, and hydrologic properties are quite dissimilar. Three of the six sites Investigated in this study are in vitric tuffs, and three sites are in zeolitic tuffs.

Lithologic, chemical, mineralogic, and modal petrographic data were collected for samples collected from all of the sites investigated. These data were compared to similar cxisting data sets for the tuffaceous beds of Calico Hills within the exploration block. Some hydrologic information for several of the locations investigated is also presented but was not considered in the evaluation process because hydrologic data are not avallable for all of the sites. Based on these comparisons, the sites best approximating the geologic conditions of the vitric Calico Hills unit within the exploration block are at Busted Butte and in the northeastern part of Yucca Mountain. Bedded tuffs at Busted Butte Include, in ascending order, the nonwelded top of the Prow Pass Member, the Wahmonie Formation, the tuffaceous beds of Calico Hills, and the nonwelded base of the Topopah Spring Member. Bedded tuffs in the northeastern part of Yucca Mountain include the nonwelded top of the Pah Canyon Member and overlying bedded tuffs. Although part of a different stratigraphic succession, these tuffs have lithologic, mineralogic, and chemical propertles that make them good analogs to the tuffaceous beds of Calico Hills within the exploration block.

The sites best approximating the geologic conditions within the zeolitic tuffaceous beds of Calico Hills within the exploration block are at Prow Pass and in the northeastern part of Yucca Mountain. The thick sequence of zeolitic tuffs exposed at Prow Pass consists of the tuffaceous beds of Calico Hills and nonwelded base of the Topopah Spring Member and are exposed in continuous vertical section for several kilometers along a $\mathrm{N}$-striking outcrop. The zeolitic tuffs making up these outcrops are generally similar to the zeolitic tuffs within the exploration block except for some differences in mineralogy and chemistry. Tuffs in the northeastern part of Yucca Mountain include the nonwelded base of the Pah Canyon Member and underlying bedded tuffs. These zeolitic tuffs also are generally similar to the zeolltic tuffs within the exploration block except for some differences in mineralogy and chemistry.

Additional screening should take place when hydrologic property data become avallable for the sites investigated in this study, although hydrologic properties are largely controlled by lithologic and mineralogic characteristics of the tuffs. Most likely, the range of hydrologic properties within the four favorable sites identified in this report will overlap those of the vitric and zeolitic tuffs within the exploration block.

\section{ACKNOWLEDGMENTS}

A.L. Flint of the U. S. Geological Survey kindly provided hydrologic data used in this report. R. G. Warren and D. Buesch provided a critical review of the manuscript. We thank Carol White for her 
help with word processing on the text and tables.

This work was supported by the U. S. Department of Energy Yucca Mountain Site Characterization Project Office as part of the Civilian Radioactive Waste Management Program. This project is managed by the U. S. Department of Energy, Yucca Mountain Site Characterization Office.

\section{REFERENCES}

Ames, L. L., Jr., 1960, The cation sleve propertles of clinoptllolite: Amer. Mineral., v. 45, p. 689-700. NNA.921026.0010

Bish, D. L., 1984, Effects of exchangeable cation composition on the thermal expansion/contraction of clinoptlolite, Clays and Clay Miner., v. 32, p. 444-462. NNA.921026.0009

Bish, D. L., 1985, Effects of composition on the dehydration behavior of clinoptilolite and heulandite, in Proceedings for the International Conference on the Occurrence, Properties, and Utilization of Natural Zeolites, Budapest, Hungary, p. 565-576. NNA.890525.0001

Bish, D. L. and Chipera, S. J., 1988, Problems and solutions in quantitative analysis of complex mixtures by X-ray powder diffraction, in Advances in X-Ray Analysis (Plenum Press, New York, 1988), v. 31, p. 295-308. NNA.890405.0178

Bish, D. L. and Chipera, S. J., 1989, Revised mineralogic summary of Yucca Mountaln, Nevada, Los Alamos National Laboratory Report LA-1 1497-MS. NNA.891019.0029

Broxton, D. E., Warten, R. G., Hagan, R. C., and Luedemann,G., 1986, Chemistry of diagenetucally altered tuffs at a potential nuclear waste repository, Yucca Mountain, Nye County, Nevada, Los Alamos National Laboratory Report LA-10802-MS, 160 p. NNA.890327.0036

Broxton, D. E., Bish, D. L., Warren, R. G., 1987, Distribution and chemistry of diagenetic minerals at Yucca Mountain, Nye County, Nevada, Clays and Clay Miner., v. 35, p. 89-110. NNA.890222.0053

Broxton, D. E., Byers, F. M. Jr., and Warren, R. G., 1989a, Petrography and phenocryst chemistry of volcanic units at Yucca Mountain, Nevada: A comparison of outcrop and drill holc samples, Los Alamos National Laboratory Report LA-11503-MS, 66 p. NNA.890224.0089

Broxton, D. E., Warren, R. G., Byers, F. M., Jr., and Scott, R. B., 1989b, Chemical and mincralogic 
trends within the Timber Mountain-Oasis Valley caldera complex: Evidence for multiple cycles of chemical evolution in a long-llved sllicic magma system, J. Geophys. Res., v. 94, p. 5961 5985. NNA.920319.0004

Bush, D. and Jenkins, R. E., 1970, Proper hydration of clays for rock property determination, J. Petroleum Technology, July issue, p. 800-804. NNA.921026.0003

Byers, F. M., Jr., Carr, W. J., Orkild, P. P., Quinlivan, W. D., and Sargent, K. A., 1976, Volcanic sultes and related cauldrons of Timber Mountain-Oasis Valley caldera complex, southern Nevada, U.S. Oeol. Surv. Prof. Paper 919, 70 p. NNA.870406.0239

Byers, F. M., Jr., 1985, Petrochemical variation of the Topopah Spring Tuff matrix with depth (stratigraphic level), drill hole USW G-4, Yucca Mountain, Nevada, Los Alamos National Laboratory Report LA-11503-MS, 38p. NNA.890224.0089

Byers, F. M., Jr., 1990a, Procedure for determination of volume constituents in thin section, Los Alamos National Laboratory detailed procedure TWS-ESS-DP-102. NNA.890710.0152

Byers, F. M., Jr., 1990b, Procedure for counting opaque minerals in polished thin sections, Los Alamos National Laboratory detalled procedure TWS-ESS-DP-128. NNA.900809.0032

Christiansen, R. L. and Lipman, P. W., 1965, Geologic map of the Topopah Spring NW quadrangle, Nye County, Nevada, U. S. Geol. Surv. Geol. Quad. Map, GQ-444. NNA.921026.0008

Chung, F. H., 1974a, Quantitative interpretation of X-ray diffraction patterns of mixtures. I. Matrixflushing method for quantitative multicomponent analysis, Jour. of App. Crystallography, v. 7, p. 519.525. NNA.890405.0179

Chung, F. H., 1974b, Quantitative interpretation of X-ray diffraction patterns of mixtures. II. Adiabatic principle of X-ray diffraction analysis of mixtures, Jour. of App. Crystallography, v. 7, p. 526. 531. NNA. 890405.0180

Flint, L. E. and Flint A. L.. 1990, Preliminary permeability and water-retention data for nonwelded and bedded tuff samples, Yucca Mountain area, Nye County, Nevada, U. S. Geol. Surv. Open-File Rept. 90-569, 56 p. NNA.901015.0200 
Flood, T. P., Vogel, T. A., and Schuraytz, B. C., 1989, Chemical evolution of a magmatic system: The Paintbrush Tuff, southwestern Nevada volcanic field, J. Geophys. Res., v. 94, No. 85, p. 59435960. NNA.921026.0013

Garcia, S. R., Hensley, W. K., Minor, M. M., Denton, M. M., Fuka, M. A., 1982, An automated multudetector system for instrumental neutron activation analysis of geological and environmental materlals, in Atomic and Nuclear Methods in Fossil Energy Research, R. H. Filby, B. S. Carpenter, and R. C. Ragalni, eds., (Plenum Press, New York), p. 133-140. NNA.921026.0001

KJug, H. P. and Alexander, L. E., 1974, X-Ray Diffraction Procedures for Polycrystalline and Amorphous Materials, John Wiley \& Sons, Inc, New York. Readlly Avallable

Korotev, R. L., 1991, Geochemical stratigraphy of two regolith cores from the central highlands of the moon, Procs. of Lunar and Planet. Sci., v. 21, p. 229.289. NNA.921019.0162

LJpman, P. W. and McKay, E. J., 1965, Geologic map of the Topopah Spring SW quadrangle, Nye County, Nevada, U. S. Geol. Surv. Geol. Quad. Map, GQ-439. NNA.900720.0032

Lupman, P. W., Christiansen, R. L., and O'Conner, J. T., 1966, A compositionally zoned ash-flow sheet in southern Nevada, U. S. Geol. Surv. Prof. Paper 524-F, p. F1-F47. NNA.870519.0035

Maldonado, F., 1985, Geologic map of the Jackass Flats area, Nye County, Nevada, U. S. Geol. Surv. Misc. Inv. Map I-1519. Readily Available

McKay, E. J. and Sargent, K. A., 1970, Geologic map of the Lathrop Wells quadrangle, Nye County, Nevada, U. S. Geol. Surv. Geol. Quad. Map, GQ-883. NNA.910215.0250

Minor, M. M., Hensley, W. K., Denton, M. M., and Garcia, S. R., 1982, An automated activation analyses system, J. Radioanal. Chem., v. 70, p. 459-471. NNA.921026.0004

Ortiz, T. S., Williams, R. L., Nimick, F. B., Whittet, B. C., and South, D. L., 1985, A three-dimensional model of reference thermal-mechanical stratigraphy at Yucca Mountain, southern Nevada, Sandia National Laboratory Report, SAND84-1076, 71 p. NNA.890315.0013 
Poole, F. O., Carr, W. J., and Elston, D. P., 1965, Salyer and Wahmonje formations of southern Nye County, Nevada, in Changes in Stratigraphic Nomenclature by the U. S. Geological Survey, 1964, G. V. Cohee, and W. S. West, eds., U. S. Geol. Surv. Bull. 1224-A, p. 36-44. NNA.921026.0007

Quinlivan, W.D. and Byers, F.M., Jr., 1977, Chemlcal data and variation diagrams of Igneous rocks from the Timber Mountain-Oasis Valley caldera complex, southern Nevada, U. S. Geol. Surv. OpenFlle Rept. 77-724, 9 p. NNA.920921.0110

Rautman, C. A., 1991, Estimates of spatial correlation in volcanic tuff, Yucca Mountaln, Nevada, Sandla National Laboratory Report, SAND89-2270, 117 p. NNA.901213.0067

Rautman, C. A., Flint, A. L., Chornack, M. P., and McGraw, M. P., 1991, Microstratigraphic units and spatial correlation of hydrologic properties In tuff, Yucca Mountaln, Nevada, Geol. Soc. America Programs with Abstracts, v.23, no.5, p. A119. NNA.920102.0081

Rautman, C. A. and Flint, A. L., 1992, Deterministic geologic processes and stochastic modeling, in Proceedings of the 3rd High-Level Radioactuve Waste Management Conference, American Nuclear Society, p. 1617-1624. NNA.920219.0016

Schuraytz, B. C., Vogel, T. A., Younker, L. W., 1989, Evidence for dynamic withdrawl from a layered magma body: The Topopah Spring Tuff, southwestern Nevada, J. Geophys. Res., v. 94, No. 85, p. 5925-5942. NNA.921026.0012

Scott, R. and Castellanos, M., 1984, Preliminary report on the geologic character of the drill holes USW GU-3 and USW G-3, U. S. Geol. Surv. Open-File Rept. 84-491, 121 p. NNA.890804.0017

Soeder, D. J., Flint, L. E., and Flint, A. L., 1991, Effects of sample handling and measurement methodology on the determination of porosity in volcanic rock samples, Agronomy Abstracts, 1991 Annual Mtgs., Amer. Soc. of Agronomy, Crop Science Soc. of Amer., and Soll Science Soc. of Amer., p. 232. NNA.920707.0070

Spengler, R. W. and Peterman, Z. E., 1991, Distribution of rubldium, strontium, and zirconium in tuff from two deep coreholes at Yucca Mountain, Nevada, in Proceedings of the 2nd High-Level Radioactive Waste Management Conference, American Nuclear Society, p. 1416-1422. NNA.911003.0095 
Vaughn, D. E. W., 1978, Propertles of natural zeolites: In Natural Zeolltes: Occurrences, Propertles, Use, L. B. Sand and F. A. Mumpton, eds., Pergamon Press, Elmsford, New York, p. 353-371. NNA.921026.0011

Warren, R. O. and Broxton, D. E., 1986, Mixing of sillicic and basaltic magmas in the Wahmonie Formation, southwestern Nevada volcanlc field, Nevada, EOS Trans. ACU, 67, p. 1261. NNA.921026.0005

Warren, R. G., McDowell, F. W., Byers, F. M. Jr., Broxton, D. E., Carr, W. J., and Orklld, P. P., 1988. Episodic leaks from TImber Mountaln caldera: New evidence from thyollte lavas of Fortymile Canyon, SW Nevada volcanic field, Geol. Soc. Am. Abstr. Programs, 20, p. 241. NNA.900308.0333

Warten, R. G., 1992, personal communication documented In notebook TWS-EES-1-2-92-5, p. 46-47.

Yucca Mountain Project, 1992, Data resulting from data aquisition, Technical Data Information Form, DTN GS920508312231.011, sp. 
APPENOIX A. PETROQRAPHC MODAL ANALYEES OF NONWELDED TUFPS FROM OUTOROP, YUCCA MOUNTAN, NEVADA

Bucted Bulle Area (Couthoad Blds; Elo 1 on Fio. 1)

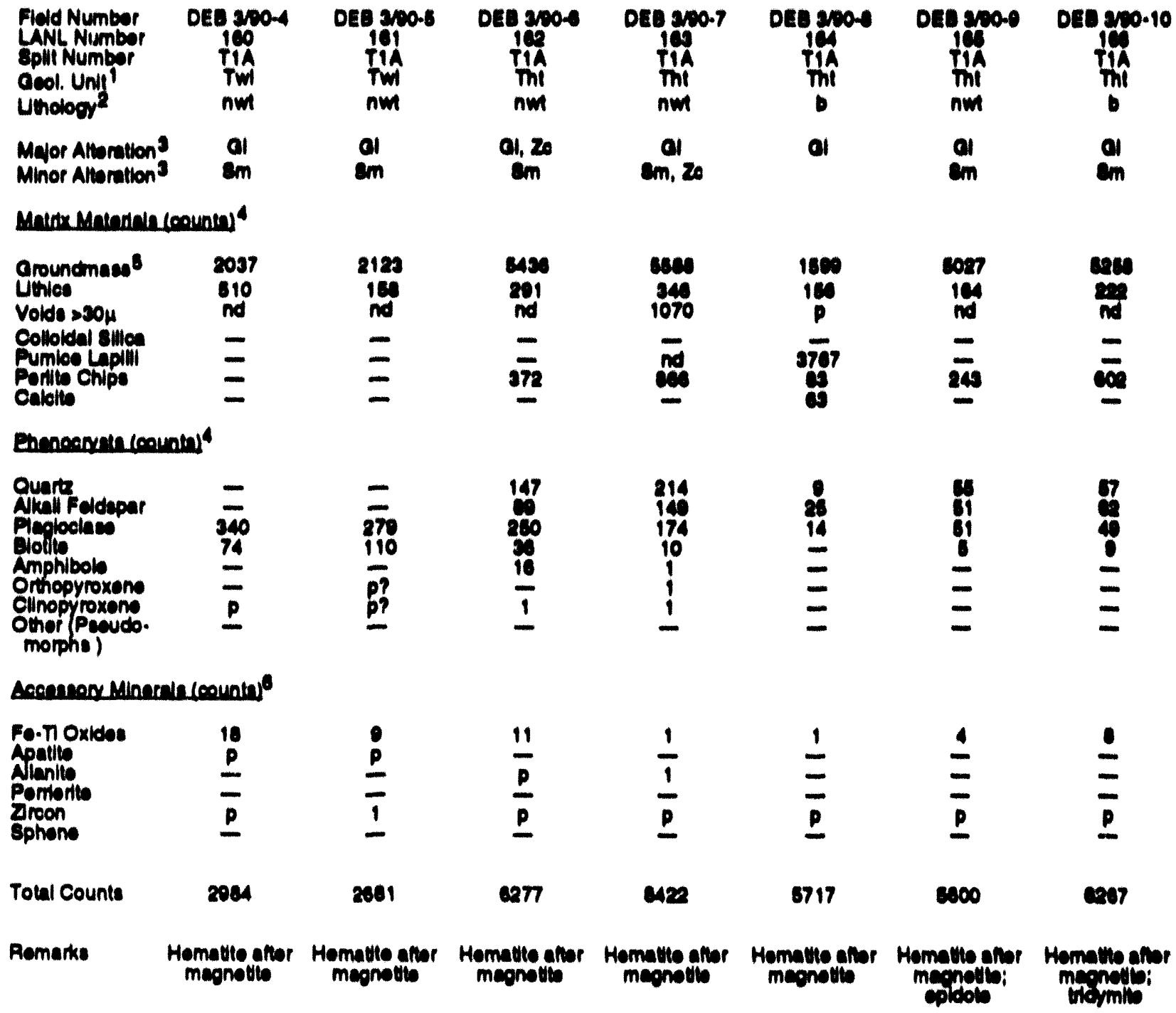

Ehenocents summex 7

Aol. $\%$ Quart

Rol. $\%$ Nk. Fold

14.6

14.8

6.8

0.6

0.0

3.0

3.0

Rol, $\%$ Plog.

8

0
0
100

18

40

10

8

$\frac{39}{32}$

37 
APPENOIX A. (oont)

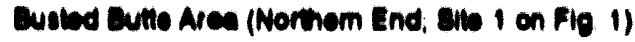

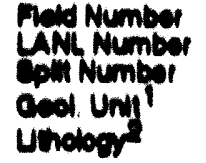

Melor Amaretions Wher Alorition?

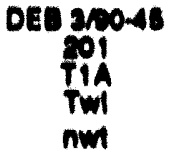

a

a) al
DEE 390.40

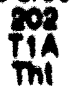

mi

b

al

in, 20

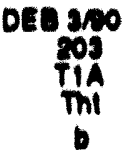

al

en

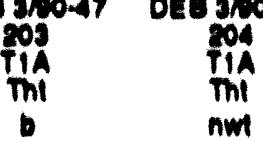

Pol

nim
Dece 3po-40

TiA

mt

num
Deg 3p0.e0

tia

num

c)

al 20
Defe 4 1.

49

TiA

Tpi

num

20

Op

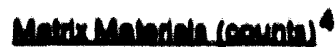

aroundinases

Utives

Voide $250 y$

collowed Ellos

Punios Livill

perilie chiss

celcto

\section{cese}

10

18

3144

$=$

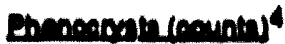

\section{guar.}

Anetrfockese

Are peives

Cono

Anphbele

Orneproxems

cinopraxene

Onei peves.

monhe)

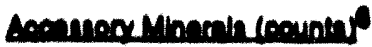

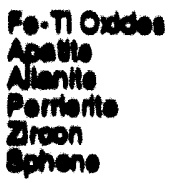

$\frac{10}{1}$

$\frac{2}{2}$

$\frac{23}{9}$

$\frac{5}{1}$

$\frac{1}{2}$

6210

7111

179
110
104
10
1
-

690

$\begin{array}{ll}198 & 170 \\ 104 & 104 \\ = & 10 \\ = & 1\end{array}$

Tow counts

11001

1000
4076

670

8317

011
0170

71

es

30
7014

80

1210

190

Henalle afier meonsive

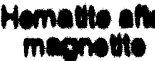

Hemolie ef meonstio

Honatte ofo meconotite

Hemalte afier meonotis; ist. ne coorecies

14
36
1
0
$=$

10

8

104

?

? rellots meconolion oph

Enementerinmax?

* Phonoeryato

0.2

10.0

20.6

13.8

6.0

89

3

39

i)

4

40

2.0
41
30

1.0
14
60

0.0

21

$\infty$

Hemalte after meoneths nt. ce ereoples

8

(1) 
APPENDix A. (00m)

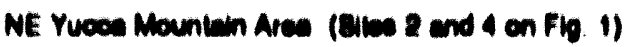
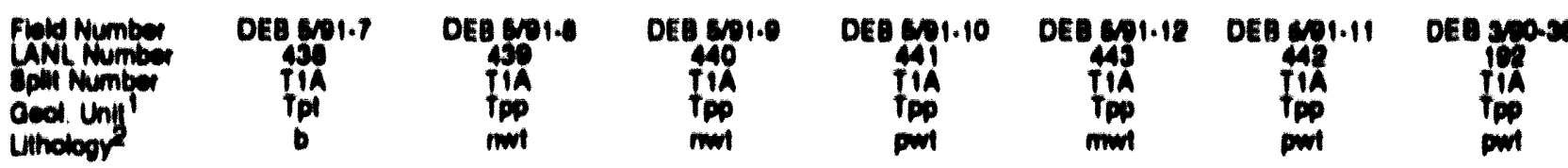

Dese seast

Major AnereVton?

2c, $2 m$, Op $\quad 2 c, 0 p$ Minor Alwotion

$8 m$

$2 m$

20. Op

om

pum

Cx, 20

$8 m$

in

210
218
248
41

17
110
-15

278

$x_{30}^{207}$

inse

it

$\overline{1347}$

colloviderition

4ass

$\underline{1304}$

1809

calolo

10

11

$1 \overline{8}$

a

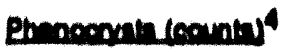

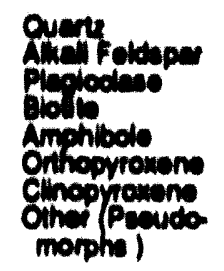

$\begin{array}{ll}8 & 10 \\ = & 30 \\ = & 5\end{array}$
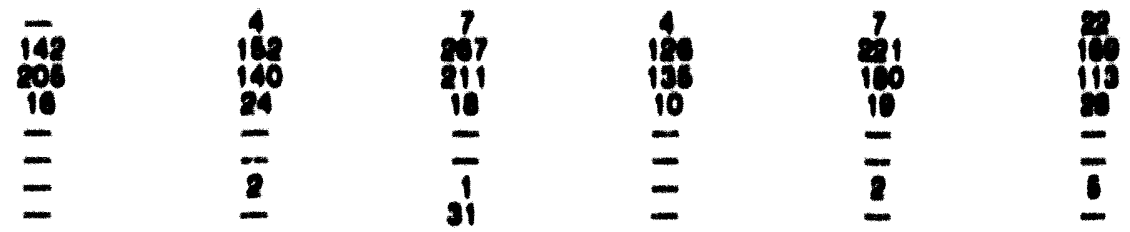

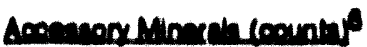

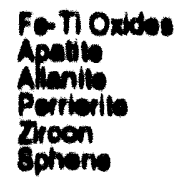

Toul Counts

11869 $\frac{14}{8}$

6109

temalie aner megnetteins. ils
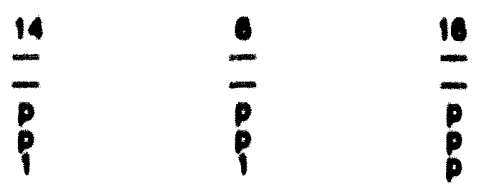

4005

sica

$\frac{9}{9}$

19e4

Hematin alle meonete; ne bo dies limen
Henetive ofle thinterint ins
Henolim and innenis $\frac{1}{8}$

coss $\frac{1}{6}$

6974

Ehanomilsummex

* Phonoarvet

Rel $\%$ Nh Fold

Ad $\%$ Ples
08

31

31

\begin{abstract}
113

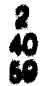

60
0
$1 !$

71

1
51
101
1
4
6.0

8

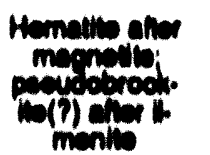

Hematy ofles monweint

in (V)
11

top

a

m 
Appanoux A. (oeni)

Ne Yued Mounian Area Cont

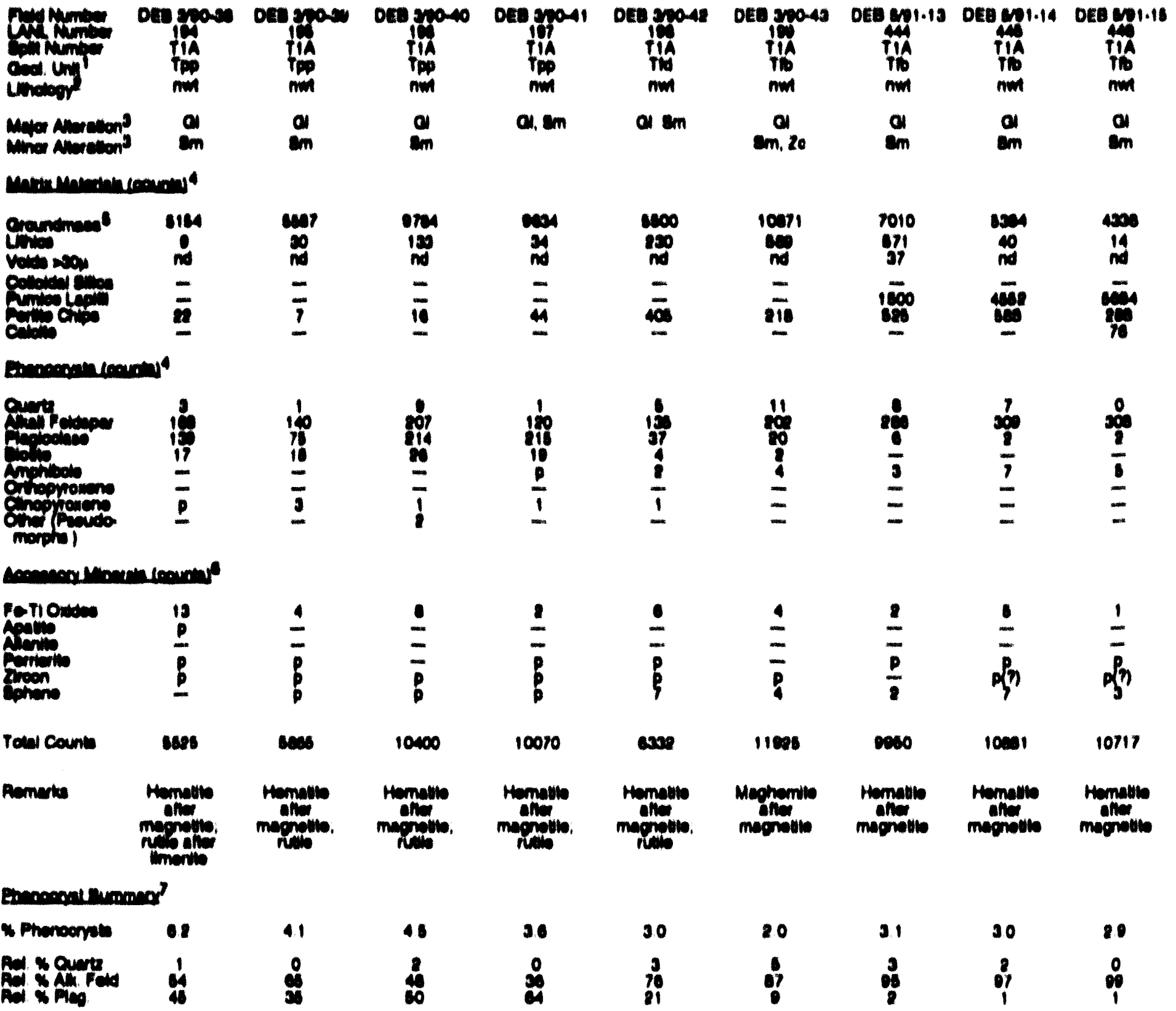




\section{APPENOIX a (oont)}

Stapeocesen Aoed Ares (Ene 3 on Fig. I)

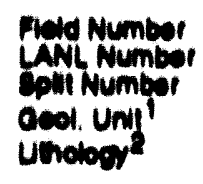

$\operatorname{itc}_{\text {Tif }}$
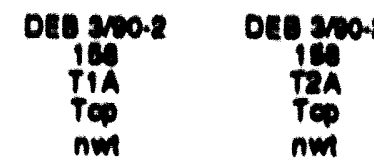
Dese seas

$\lim _{n \rightarrow \infty}$

Major Averation?

20. 09

Minot Allorition?

$2 m, 8 m$

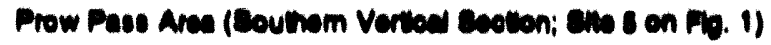

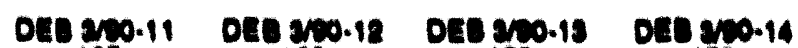

$\prod_{i 1}^{110}$

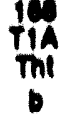

$\operatorname{in}_{n \in}^{1}$

$\operatorname{lin}_{n \rightarrow \infty}^{10}$

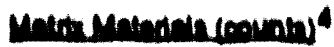

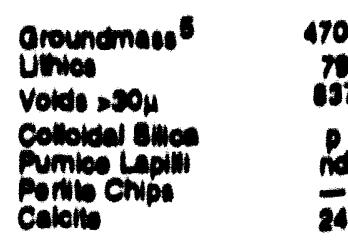

$\frac{1700}{24}$

Enenomancominist

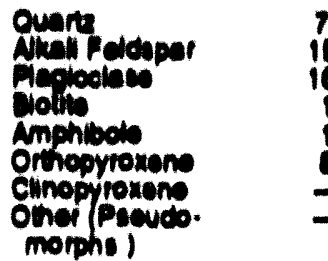

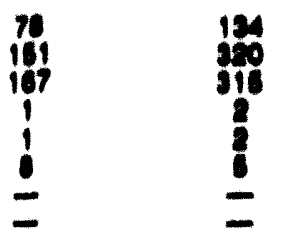

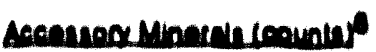

\section{Fo.ñ Orides \\ Aolvo \\ Atrinta \\ Porrionto \\ zreen \\ ephine}

$\frac{18}{p}$

$\cos 1$

Told Counis

Mathe Pacucto. morph Hom Uis ener meo. notivi cecond. on opeques

Enenocovilsummax

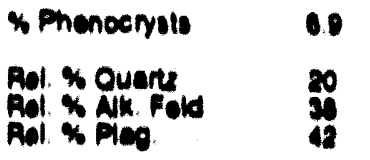

80

a

2., en, $\infty_{p}$

20. 0

cm
88

17

a $\frac{1}{p}$

$\frac{7}{2}$

407

$\frac{14}{7}$

20. $2 m$, op

in

20, 0

$2 n, 0 m$

2n. $\mathrm{cm}$

\begin{tabular}{ll|l}
400 & 2000 & 207 \\
301 & 104 & 200 \\
$=$ & nd & \\
$=$ & $=$ & 19
\end{tabular}

$\frac{-197}{20}$

$\frac{29}{2}$

$=$

$=$

$\frac{7}{1}$

$\underline{\underline{p}}$

4001

600

409

1109

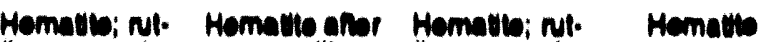

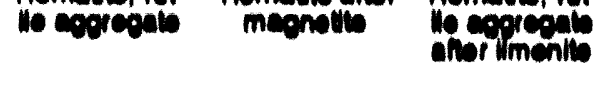

Hemalle afier mecnoule megnoth meonowibicd. megnoth meonowibicd. megnotis meonowb; bied. (n)

$$
1
$$$$
\text { (1) }
$$

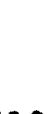

$\begin{array}{cc}10 & 13.7 \\ 8 & 9 \\ 40 & 100\end{array}$

18.0
4
18

11.1
39
89

7.6
47
80

2.4

49

21 
APPENOXX A (cont)

Prow Pass Area (Southern Vertical Bection) Cont.

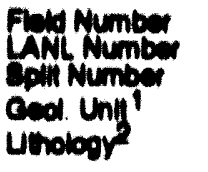

Mayor Allerallons Minot Allerallon

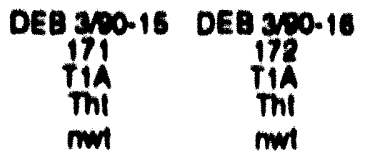

$20,2 m, O_{p} \quad 2 c, 2 m, O_{p}$ $8 m$
DEB 390-17

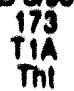

mit
DEB 300
174
TiA

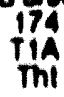

Thi
DEB $3: 0.10$

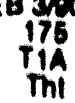

mw
DEB 390.20
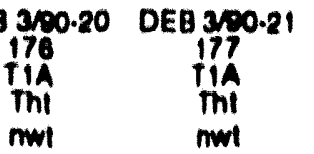

OEB 390.22

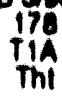

Tht
DEB 300-23

170

Thi

now

Matrelenterlecountr)

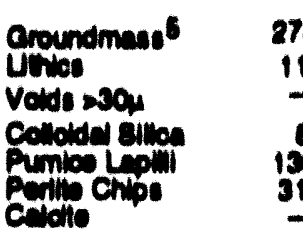

\begin{tabular}{cc}
2703 & 3237 \\
114 & 401 \\
- & 30 \\
1368 & 29 \\
310 & 204 \\
\hline
\end{tabular}

$106 \% 0$
600
700
6
nd
130

2c. $2 m$. Op

2c. $2 m, O p$

2c. $2 m$. Op

Zc. $2 m$, Op

$8 m$

$8 m$

$8 m$

$8 m$

$8 m$

$2 c, 2 m, O p$

$2 c, 2 m, O p$

$8 m$

$8 m$

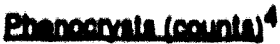

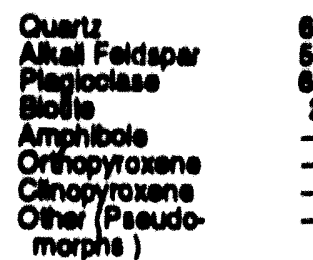

$\begin{array}{lll}02 & 77 & 111 \\ 63 & 60 & 71 \\ 5 & 35 & 64 \\ 2 & 2 & = \\ = & = & = \\ = & = & 10\end{array}$

6000
278
660
209
2540
330

3001
00
317
317
2132
84
-

4177
133
10
10
1647
143
-

4257
126
17
17
1100
110
-

3310
690
208
208
997
140

0134

310

2005

030

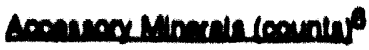
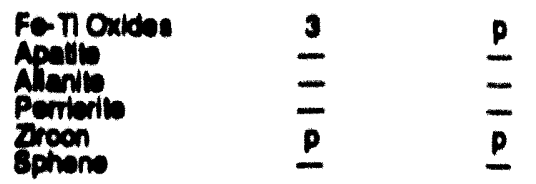

$\frac{3}{2}$
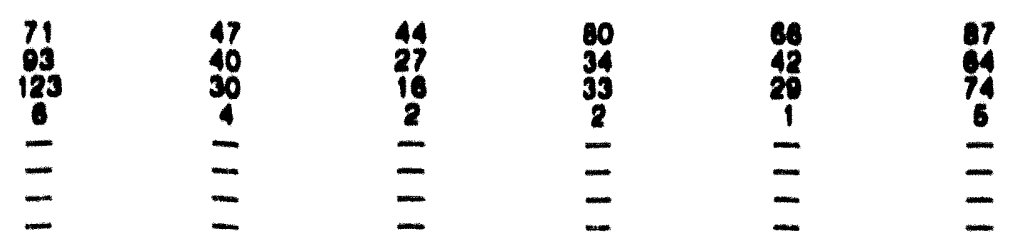

Told Counte

4772

0644

12213

10088

6046

6100

8698

6280

12117

Aemerte

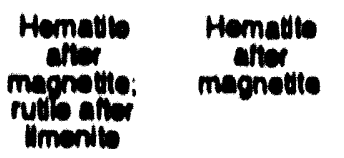

Hemalse

Hemalto

Hemalle

Hernatle Magnotlo

Hemadre

Hematite aller magnetlo magnetto mognetile magnets magnetito

Eromonterinmar

\% Phoneeryits

3.8

Ad. $\%$ querts

Ad. \% A. Feld

Ad $\%$ Plag
36
30

2.6
48
31
22
2.1

20

26

$\begin{array}{ll}2.8 & 2.0 \\ 25 & 40 \\ 32 & 34 \\ 43 & 26\end{array}$

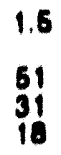

1.6
51
31
10

2.6
54
23
22

2.5
18
31
21

1.0
30
30


APPENDIX A. (cont)

Prow Pass Area (Southem Vertical Section) Cont.

\begin{tabular}{|c|c|c|c|c|c|c|c|c|}
\hline $\begin{array}{l}\text { Field Number } \\
\text { LANL Number } \\
\text { Split Number } \\
\text { jeol. Unit }{ }^{1} \\
\text { Lthology }{ }^{2}\end{array}$ & $\begin{array}{c}\text { DEB 3/90-24 } \\
180 \\
\text { T1A } \\
\text { Tht } \\
\text { nwt }\end{array}$ & $\begin{array}{c}\text { DEB } 3 / 90-25 \\
181 \\
\text { T1A } \\
\text { Tht } \\
\text { nwt }\end{array}$ & $\begin{array}{c}\text { DEB } 3 / 90-26 \\
182 \\
\text { T1A } \\
\text { Tht } \\
\text { b }\end{array}$ & $\begin{array}{c}\text { DEB } 3 / 90-27 \\
183 \\
\text { T1A } \\
\text { Tht } \\
\text { nwt }\end{array}$ & $\begin{array}{c}\text { DEB } 3 / 90-28 \\
184 \\
\text { T1A } \\
\text { Tht } \\
n w t\end{array}$ & $\begin{array}{c}\text { DEB } 3 / 90-29 \\
185 \\
\text { T1A } \\
\text { Tht } \\
\text { nwt }\end{array}$ & $\begin{array}{c}\text { DEB } 3 / 90-30 \\
186 \\
\text { T1A } \\
\text { Tht } \\
\text { b }\end{array}$ & $\begin{array}{c}\text { DEB } 3 / 90-3 \\
187 \\
\text { TiA } \\
\text { Tht } \\
\text { nwt }\end{array}$ \\
\hline $\begin{array}{l}\text { Major Alteration } 3 \\
\text { Minor Alteration }\end{array}$ & $\begin{array}{c}Z c, Z_{\operatorname{Sin}}, O p \\
\text { Op }\end{array}$ & $\begin{array}{c}\mathrm{Zc}, \mathrm{Zm}_{\mathrm{Sm}} \text { Op } \\
\text { op }\end{array}$ & $\begin{array}{l}\mathrm{Zc}, \mathrm{Zm}, \mathrm{Op} \\
\mathrm{Sm}\end{array}$ & $\begin{array}{c}Z c_{1}, Z_{1}, O p \\
S m\end{array}$ & $\begin{array}{l}\mathrm{Zc}, \mathrm{Zm}, \mathrm{Op} \\
\mathrm{Sm}\end{array}$ & $\mathrm{Zc}, \mathrm{Zm}, \mathrm{Op}$ & $Z c, Z m, O p$ & $\underset{\mathrm{Zm}}{\mathrm{Zc}, \mathrm{Zm}, \mathrm{Op}}$ \\
\hline \multicolumn{9}{|c|}{ Matrix Materials (counts) ${ }^{4}$} \\
\hline $\begin{array}{l}\text { Groundmass } 5 \\
\text { Lithics } \\
\text { Voids }>30 \mu\end{array}$ & $\begin{array}{c}4158 \\
138 \\
\text { nd }\end{array}$ & $\begin{array}{c}5640 \\
83 \\
\text { nd }\end{array}$ & $\begin{array}{c}4358 \\
725 \\
\text { nd }\end{array}$ & $\begin{array}{c}6133 \\
414 \\
150\end{array}$ & $\begin{array}{c}5565 \\
161 \\
82\end{array}$ & $\begin{array}{c}3324 \\
376 \\
48\end{array}$ & $\begin{array}{c}5127 \\
175 \\
\text { nd }\end{array}$ & $\begin{array}{c}7350 \\
134 \\
656\end{array}$ \\
\hline $\begin{array}{l}\text { Colloidal Sillica } \\
\text { Pumice Lapilli } \\
\text { Perlite Chips } \\
\text { Calcite }\end{array}$ & $\begin{array}{c}183 \\
1795 \\
=\end{array}$ & $\frac{\overline{-}}{243}$ & $\frac{57}{481}$ & $\begin{array}{c}p \\
3555 \\
348 \\
-\end{array}$ & $\overline{197}$ & $\begin{array}{c}-\overline{1247} \\
556 \\
-\end{array}$ & $\frac{14}{113}$ & $\begin{array}{c}\overline{2682} \\
290 \\
-\end{array}$ \\
\hline
\end{tabular}

Phenocrysts (counts) ${ }^{4}$

Alkall Foldspar

Plagioclaso

Blotito

Amphibole

Orthopyroxene

Clinopyroxene

Other (Pseudo.

morphs )

$\begin{array}{cc}36 & 64 \\ 8 & 91 \\ 15 & 26 \\ 1 & 2 \\ = & = \\ = & \underline{p}\end{array}$

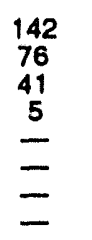

123
110
19
8
$=$
$=$

45
51
33
9
$=$
$=$
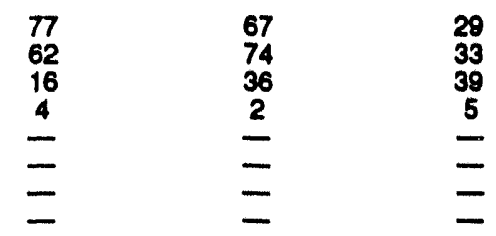

Accessony Minerals (counts) 6

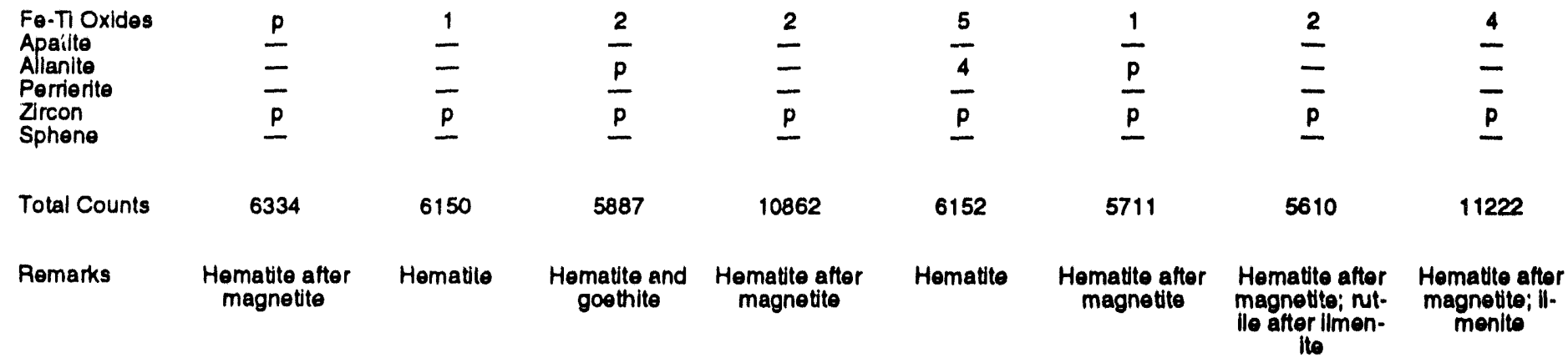

Phenocryst Summary ${ }^{7}$

$\begin{array}{lllllllll}\text { \% Phenccrysts } & 0.9 & 3.0 & 4.5 & 2.4 & 2.3 & 2.8 & 3.2 & \\ \text { Rel. \% (2uartz } & 61 & 35 & 55 & 49 & 35 & 50 & 38 \\ \text { Rel. \% Alk. Feld } & 14 & 50 & 29 & 44 & 40 & 40 & 29 \\ \text { Rel. \% Plag. } & 25 & 14 & 16 & 8 & 26 & 10 & 20 & 33\end{array}$


APPENDIX A. (cont)

\begin{tabular}{|c|c|c|c|c|c|c|c|c|c|}
\hline \multirow[b]{2}{*}{$\begin{array}{l}\text { Flold Number } \\
\text { LANL. Number } \\
\text { Split Number } \\
\text { Geol. Unilf } \\
\text { Lithology }\end{array}$} & \multicolumn{4}{|c|}{ Prow Pass Area (Southern Vertical Section) Cont. } & \multicolumn{5}{|c|}{ Prow Pass Area (N-S Lateral Section; Slte 5 on Fig. 1) } \\
\hline & $\begin{array}{c}\text { DEB 3/90-32 } \\
188 \\
\text { T1A } \\
\text { Tht } \\
\text { nwt }\end{array}$ & $\begin{array}{c}\text { DEB } 3 / 80-33 \\
189 \\
T 1 A \\
T p t \\
n w t\end{array}$ & $\begin{array}{c}\text { DEB } 3 / 90-34 \\
190 \\
\text { T1A } \\
\text { Tpt } \\
v t\end{array}$ & $\begin{array}{c}\text { DEB } 3 / 90-35 \\
191 \\
\text { T1A } \\
\text { Tpt } \\
v t\end{array}$ & $\begin{array}{c}\text { CRPP.1-SNL } \\
126 \\
\text { T1A } \\
\text { Tht } \\
\text { nwt }\end{array}$ & $\begin{array}{c}\text { CAPP_-2-SNL } \\
127 \\
\text { T1A } \\
\text { Tht } \\
\text { mwt }\end{array}$ & $\begin{array}{c}\text { CRPP-3-SNL } \\
128 \\
\text { T1A } \\
\text { Tht } \\
\text { nwt }\end{array}$ & $\begin{array}{c}\text { CRPP-4-SNL } \\
129 \\
\text { T1A } \\
\text { Tht } \\
\text { mit }\end{array}$ & $\begin{array}{c}\text { CRPP.5-SNL } \\
130 \\
\text { TiA } \\
\text { Tht } \\
\text { nWI }\end{array}$ \\
\hline $\begin{array}{l}\text { Major Alteration } 3 \\
\text { Minor Alteration }\end{array}$ & $\begin{array}{l}\mathrm{Zc}, \mathrm{Zm}, \mathrm{Op} \\
\mathrm{Sm}\end{array}$ & $\underset{\mathrm{Zm}}{\mathrm{Zc}, \mathrm{Zm}}$ & GI, Zc, Zm,Op & $\begin{array}{l}\text { GI } \\
\text { Op }\end{array}$ & $Z c, Z m, O p$ & $\mathrm{Zc}, \mathrm{Zm}, \mathrm{Op}$ & $\mathrm{Zc}, \mathrm{Zm}, \mathrm{Op}$ & $\underset{\mathrm{Sm}}{\mathrm{Zc}, \mathrm{Zm}, \mathrm{Op}}$ & $\begin{array}{c}\mathrm{Zc}, \mathrm{Zm}, \mathrm{Op} \\
\mathrm{Sm}\end{array}$ \\
\hline \multicolumn{10}{|c|}{ Matrix Materials (counts) ${ }^{4}$} \\
\hline $\begin{array}{l}\text { Groundmass } 5 \\
\text { Littics } \\
\text { Volds }>30 \mu \\
\text { Colloldal Silica } \\
\text { Pumice Lapilli } \\
\text { Porlite Chips } \\
\text { Calaibs }\end{array}$ & $\begin{array}{l}8558 \\
582 \\
870 \\
-\overline{2242} \\
104 \\
-\end{array}$ & $\begin{array}{l}10248 \\
60 \\
\text { nd } \\
= \\
\overline{80}\end{array}$ & $\begin{array}{l}11172 \\
230 \\
\text { nd } \\
= \\
= \\
=\end{array}$ & $\begin{array}{c}11759 \\
69 \\
\text { nd } \\
= \\
= \\
=\end{array}$ & $\begin{array}{l}10578 \\
942 \\
344 \\
\overline{\text { nd }} \\
554 \\
-\end{array}$ & $\begin{array}{c}3796 \\
720 \\
346 \\
- \\
3872 \\
1876 \\
68\end{array}$ & $\begin{array}{c}5190 \\
470 \\
208 \\
- \\
5582 \\
524 \\
16\end{array}$ & $\begin{array}{l}3458 \\
76 \\
\text { nd } \\
64 \\
2213 \\
153 \\
-\end{array}$ & $\begin{array}{l}3052 \\
59 \\
\text { nd } \\
356 \\
1726 \\
116 \\
-\end{array}$ \\
\hline \multicolumn{10}{|c|}{ Phenocrusts (counts) ${ }^{4}$} \\
\hline $\begin{array}{l}\text { Quartz } \\
\text { Alkall Feldspar } \\
\text { Plagloclase } \\
\text { Blotitg } \\
\text { Amphibole } \\
\text { Orthopyroxene } \\
\text { Cllnopyroxene } \\
\text { Other (Pseudo } \\
\text { morphs) }\end{array}$ & $\begin{array}{l}39 \\
30 \\
119 \\
4 \\
= \\
=\end{array}$ & $\begin{array}{l}0 \\
5 \\
25 \\
3 \\
= \\
= \\
=\end{array}$ & $\begin{array}{l}7 \\
15 \\
20 \\
1 \\
p \\
- \\
-\end{array}$ & $\begin{array}{l}9 \\
26 \\
91 \\
\vdots \\
= \\
= \\
=\end{array}$ & $\begin{array}{l}128 \\
114 \\
74 \\
4 \\
p \\
= \\
=\end{array}$ & $\begin{array}{l}109 \\
113 \\
56 \\
3 \\
= \\
=\end{array}$ & $\begin{array}{l}115 \\
101 \\
37 \\
4 \\
= \\
=\end{array}$ & $\begin{array}{l}18 \\
56 \\
31 \\
6 \\
= \\
=\end{array}$ & $\begin{array}{l}30 \\
24 \\
19 \\
3 \\
= \\
= \\
=\end{array}$ \\
\hline \multicolumn{10}{|c|}{ Accesson Minerals (counts) ${ }^{6}$} \\
\hline $\begin{array}{l}\text { Fe-TI Oxides } \\
\text { Apatite } \\
\text { Alanito } \\
\text { Perrierite } \\
\text { Zrcon } \\
\text { Sphene }\end{array}$ & $\frac{5}{p}$ & $\frac{5}{p}$ & $\frac{3}{\frac{1}{p}}$ & $\frac{5}{p}$ & $\frac{\frac{1}{5}}{\frac{p}{-}}$ & $\frac{1}{\bar{p}}$ & $\frac{1}{-}$ & $\frac{1}{\frac{1}{p}}$ & $\frac{p}{\frac{p}{p}}$ \\
\hline Total Counts & 12643 & 10426 & 11448 & 11960 & 12744 & 10960 & 12248 & 6076 & 5395 \\
\hline Phenocnust Summ & $\begin{array}{c}\text { Hematite } \\
\text { after } \\
\text { magnetite; } \\
\text { maghem- } \\
\text { ile(?) } \\
\text { narx }\end{array}$ & $\begin{array}{l}\text { Hematite } \\
\text { after } \\
\text { magnetite; } \\
\text { rutile with } \\
\text { ilmenite } \\
\text { relicts }\end{array}$ & $\begin{array}{l}\text { Hemabte } \\
\text { after } \\
\text { magnetite; } \\
\text { rutile after } \\
\text { ilmenite }\end{array}$ & Hematite & $\begin{array}{c}\text { Hematite after } \\
\text { magnetite }\end{array}$ & $\begin{array}{l}\text { Hematite after } \\
\text { magnetite }\end{array}$ & $\begin{array}{c}\text { Hematite after } \\
\text { magnetite }\end{array}$ & $\begin{array}{c}\text { Hematite after } \\
\text { magnetile }\end{array}$ & $\begin{array}{l}\text { Hematite after } \\
\text { magnetite }\end{array}$ \\
\hline \% Phenocrysts & 1.6 & 0.4 & 0.4 & 1.1 & 2.5 & 2.6 & 2.1 & 1.8 & 1.6 \\
\hline $\begin{array}{l}\text { Rol. } \%_{0} \text { Quartz } \\
\text { Rel. \% Alk. Fold } \\
\text { Rel. \% Plag. }\end{array}$ & $\begin{array}{l}21 \\
16 \\
63\end{array}$ & $\begin{array}{r}0 \\
17 \\
83\end{array}$ & $\begin{array}{l}17 \\
36 \\
48\end{array}$ & $\begin{array}{r}7 \\
21 \\
72\end{array}$ & $\begin{array}{l}41 \\
36 \\
23\end{array}$ & $\begin{array}{l}39 \\
41 \\
20\end{array}$ & $\begin{array}{l}45 \\
40 \\
15\end{array}$ & $\begin{array}{l}17 \\
53 \\
30\end{array}$ & $\begin{array}{l}48 \\
29 \\
23\end{array}$ \\
\hline
\end{tabular}


APPENDIX A. (cont)

Prow Pass Area (N-S Lateral Section) Cont.

Field Number
LANL Number
Split Number
Geol. Unit ${ }^{1}$
Lithology

Major Alteration 3 Minor Alteration ${ }^{3}$
CAPP-6-SNL CRPP.7-SNL

$\begin{array}{ll}131 & 132 \\ \text { T1A } & \text { T1A } \\ \text { Tht } & \text { Tht }\end{array}$

nwt
CRPP-8.SNL

133
T1A
Tht

nwt

nwt
CAPP.QSNL

$$
134
$$

Tht

nwt

$\mathrm{Zc}, \mathrm{Zm}, \mathrm{Op}$

Sm
Zc, Zm, Op $\mathrm{Sm}$

$$
\mathrm{Sm}
$$

CRPP.10-SNL.
135
T1A
Tht
nwt

Zc, Zm, Op

$\mathrm{Sm}$
CRPP.11-SNL CAP

136
T1A
Tht
nwt

CAPP.12-SNL

137
T1A
Tht
nwt

CRPP.13.8NL

138
TiA
Thi
nwt

CRPP.14-8NL

Zc, Zm, Op

$\mathrm{Zc}, \mathrm{Zm}, \mathrm{Op}$

Zc, Zm, Op

$8 \mathrm{~m}$

Zc, $Z m, O p$

Matrix Materials (counts) ${ }^{4}$

$\begin{array}{lcc}\text { Groundmass } 5 & 3195 & 5752 \\ \text { Lithics } & 617 & 270 \\ \text { Voids }>30 \mu & \text { nd } & \text { nd } \\ \text { Colloidal Silica } & 3 & 317 \\ \text { PLimice Lapilli } & 1545 & 4660 \\ \text { Perlite Chips } & 266 & 184 \\ \text { Calcite } & 42 & - \\ & \end{array}$

$\begin{array}{cc}6896 & 5876 \\ 677 & 268 \\ \text { nd } & \text { nd } \\ 92 & 1204 \\ 2780 & 3414 \\ 279 & 232 \\ - & 98\end{array}$

7533
225
nd
68
3494
235
-

\begin{tabular}{l}
5464 \\
334 \\
nd \\
46 \\
4524 \\
990 \\
\hline
\end{tabular}

6018
396
nd
$\overline{4144}$
336
$p$

6288
198
nd
242
3758
396
-

6296

187

49
49
17
1
$=$
$=$

$\begin{array}{ll}111 & 69 \\ 64 & 60 \\ 39 & 64 \\ 7 & 14 \\ = & = \\ = & =\end{array}$

59
47
26
7
$=$
$=$

79
65
25
4
$=$
$=$

122
79
83
4
$=$
$=$

140
83
22
1
$=$
$=$

$\begin{array}{ll}74 & 78 \\ 64 & 112 \\ 25 & 61 \\ 1 & 6 \\ = & = \\ = & =\end{array}$

\begin{tabular}{|c|c|c|c|c|c|c|c|c|c|}
\hline Fe-TiOxides & $p$ & 1 & 1 & $p$ & 1 & $\mathbf{p}$ & 2 & 2 & 6 \\
\hline $\begin{array}{l}\text { Apatite } \\
\text { Allanite }\end{array}$ & $\overline{-}$ & $=$ & $\overline{-}$ & \pm & - & - & - & - & - \\
\hline $\begin{array}{l}\text { Allanile } \\
\text { Perrierile }\end{array}$ & $\bar{z}$ & $\overline{-}$ & $\overline{-}$ & $\overline{-}$ & $\overline{-}$ & $\overline{-}$ & $\overline{-}$ & - & $\overline{-}$ \\
\hline Zircon & $p$ & $p$ & $\mathbf{p}$ & - & $p$ & $p$ & $\bar{p}$ & $\overline{-}$ & $\overline{-}$ \\
\hline Sphene & & 一 & - & - & - & - & 一 & - & - \\
\hline Total Counts & 5784 & 11405 & 10932 & 11331 & 11729 & 11646 & 11142 & 11048 & 10065 \\
\hline Remarks & $\begin{array}{l}\text { Hematite } \\
\text { after } \\
\text { magnetite }\end{array}$ & $\begin{array}{c}\text { Hematite } \\
\text { after } \\
\text { magnetite } \\
\text { and } \\
\text { maghem- } \\
\text { ite (?) }\end{array}$ & $\begin{array}{l}\text { Hematite } \\
\text { atter } \\
\text { magnetite } \\
\text { and } \\
\text { maghem- } \\
\text { ite (?) }\end{array}$ & $\begin{array}{l}\text { Hematite } \\
\text { after } \\
\text { magnetile } \\
\text { and } \\
\text { maghem- } \\
\text { lle (?) }\end{array}$ & $\begin{array}{c}\text { Hematite } \\
\text { after } \\
\text { magnetite; } \\
\text { maghem- } \\
\text { ite (?) }\end{array}$ & $\begin{array}{l}\text { Hematite } \\
\text { after } \\
\text { magnetite } \\
\text { and } \\
\text { maghem- } \\
\text { lie }(?)\end{array}$ & $\begin{array}{l}\text { Hematite } \\
\text { atter } \\
\text { magnetite } \\
\text { and } \\
\text { maghem- } \\
\text { ite (?) }\end{array}$ & $\begin{array}{l}\text { Hematile } \\
\text { after } \\
\text { magnetite } \\
\text { and } \\
\text { maghem- } \\
\text { lte }(?)\end{array}$ & $\begin{array}{l}\text { Hematite } \\
\text { after } \\
\text { magnetite } \\
\text { and } \\
\text { maghem- } \\
\text { ite (?) }\end{array}$ \\
\hline \multicolumn{10}{|c|}{ Phenocryst Summary 7} \\
\hline$\%$ Phenocrysts & 2 & 18 & 10 & 1.2 & 1.5 & 2.5 & 2.2 & 1.5 & 2.6 \\
\hline $\begin{array}{l}\text { Rel. \% Quartz } \\
\text { Rol. \% Alk. Feld } \\
\text { Rel. \% Plag. }\end{array}$ & $\begin{array}{l}43 \\
43 \\
15\end{array}$ & $\begin{array}{l}52 \\
30 \\
18\end{array}$ & $\begin{array}{l}36 \\
31 \\
33\end{array}$ & $\begin{array}{l}45 \\
36 \\
20\end{array}$ & $\begin{array}{l}47 \\
38 \\
15\end{array}$ & $\begin{array}{l}43 \\
28 \\
29\end{array}$ & $\begin{array}{c}57 \\
34 \\
9\end{array}$ & $\begin{array}{l}45 \\
39 \\
15\end{array}$ & $\begin{array}{l}31 \\
45 \\
24\end{array}$ \\
\hline
\end{tabular}

Accessory Minerals (counts) ${ }^{6}$ 
APPENDIX A. (cont)

Prow Pass Area (N-S Lateral Section) Cont.

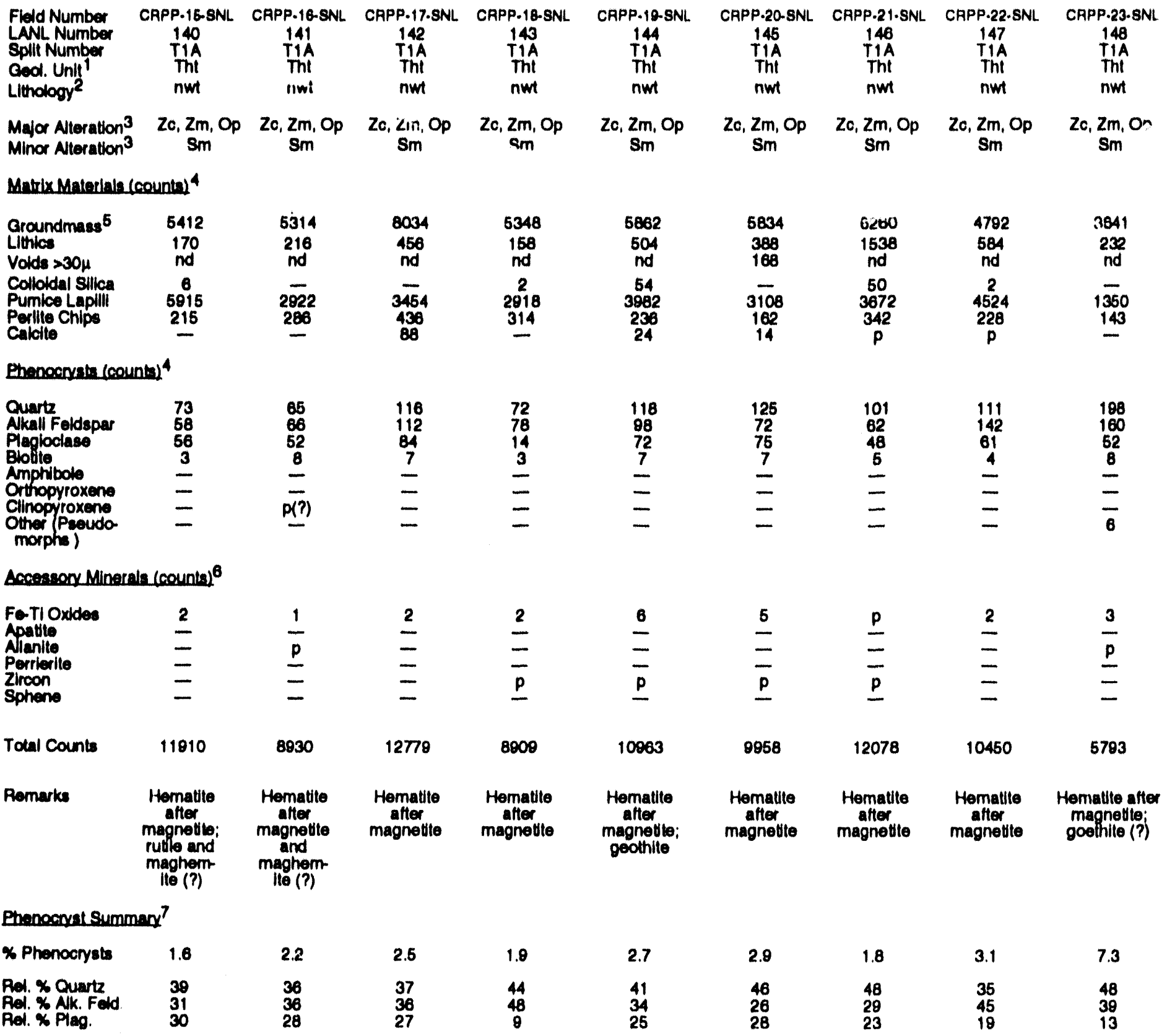


APPENDIX A. (cont)

Prow Pass Area (N.S Labral Section) Cont.

Fleld Number CAPP.24.SNL CAPP.25-SNL

LANL Number

148
TiA
Tht

CAPP.25.
150

Split Number

God. Unil ${ }^{1}$

Tht Thi

CRPP-2ASNL CRPP.27.SNL

CRPP.28-SNL CAPP.29-SNL

CAPP.30-8NL

CAPP.31-SNL

Lithology2

nut

nwt

152
TiA
Tht

153
Thi
Thi

T1A

Tht

Thi

nit

165

Tht

168

nwt

Zc, $\mathrm{Zm}$

Zc, Zm, Op

Zc, Zm, Op

Zc, $Z m, O p$

$8 m$

nwt

nut

Thi

Major Altoration 3

$\mathrm{Zm}, \mathrm{Sm}$

$\mathrm{Sm}$

$\mathrm{sm}$

Zc, $Z m, O p$

$8 m$

Zc, Zm, Op

$\mathrm{sm}$

2o, $2 m, O p$

Matrlx Materials (counta) ${ }^{4}$

$\begin{array}{lcc}\text { Caroundmass } 5 & 3300 & 4730 \\ \text { Llttics } & 62 & 782 \\ \text { Volds }>30 \mu & \text { nd } & \text { nd } \\ \text { Colloidal Sillica } & 1 & - \\ \text { Pumice Laplill } & 2346 & 3814 \\ \text { Perlite Chips } & 171 & 782 \\ \text { Calcle } & - & -\end{array}$

4630
440
nd
96
4551
330
-

8154
896
640
$\overline{n d}$
844

3275
303
nd
21
1777
214
-

5432
1122
nd
3504
736

2851
252
nd
$2 \overline{106}$
-

6792
628
nd
160
3164
668
-

Bhenocryate (counts) 4

Quarlz
Alkall Foldspar
Plagloclase
Biollito
Amphibole
Orthopyroxene
Clinopyroxeno
Othor Prendo.

$\begin{array}{ll}130 & 307 \\ 60 & 237 \\ 132 & 65 \\ 30 & 21 \\ \overline{1} & = \\ - & \overline{32}\end{array}$

Accesseory Minerals (counts) ${ }^{6}$

\begin{tabular}{|c|c|c|}
\hline $\begin{array}{l}\text { Fo.Tl Oxides } \\
\text { Apautie } \\
\text { Alianilo } \\
\text { Perriterite } \\
\text { Zircon } \\
\text { Sphene }\end{array}$ & $\frac{5}{\frac{p}{p}}$ & $\frac{5}{p}$ \\
\hline Total Counts & 6255 & 10585 \\
\hline Remarks & $\begin{array}{l}\text { Hematite after } \\
\text { magnetlite }\end{array}$ & $\begin{array}{c}\text { Hematite and } \\
\text { rutile aggre- } \\
\text { gate }\end{array}$ \\
\hline
\end{tabular}

192
160
62
19
$=$
$=$

280
208
115
13
$=$
$=$

208
151
60
13
$=$
$=$

268
168
121
21
$=$
$=$
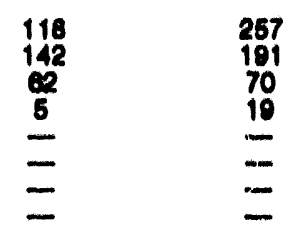

Chenocryst Summary?

\% Phenocrysts

8.0

Rel. \% Quartz

Rel. \% Alk. Fold

Pol. \% Plag.

41
20
30

\begin{abstract}
6.0
\end{abstract}
30

39

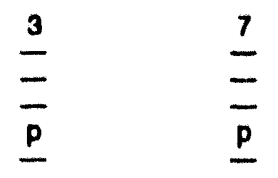

10527

Hematite and

rutlle aggre-

galo; epldote crystal

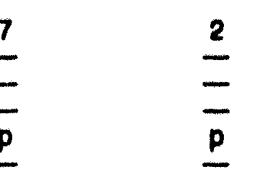

$\frac{2}{p}$

6114
Hematite; rut- 110 and goethite aggregate mematite after lite aggregate chalcedony

4.3

44
37
10

$\begin{array}{ll}5.2 & 7.1 \\ 47 & 50 \\ 34 & 36 \\ 19 & 14\end{array}$

.1
60
36
14

5.1
48
30
22

$\frac{1}{2}$

11377

$\frac{2}{p}$

$\frac{4}{p}$

5677

10041

\section{ematite and gate
garo}
Hematile and
rutile apgre-
gate; whito mica cryetal

Homatib and rutile aggre gato 
APPENDIX A. (cont)

Calleo Hills Area (E.W Lateral Section; Site 6 on Fio. 1)

\begin{tabular}{|c|c|c|c|c|c|c|c|}
\hline 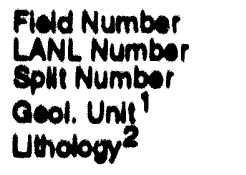 & $\begin{array}{c}\text { CRCH.1.SNL } \\
116 \\
\text { TiA } \\
\text { mi } \\
\text { nMt }\end{array}$ & $\begin{array}{c}\text { CACH.2-SNL } \\
117 \\
\text { TiA } \\
\text { Tht } \\
\text { nwt }\end{array}$ & $\begin{array}{c}\text { CRCH-3.SNL } \\
118 \\
\text { T1A } \\
\text { Tht } \\
\text { nWt }\end{array}$ & $\begin{array}{c}\text { CRCH.4.SNL } \\
119 \\
\text { TiA } \\
\text { Tht } \\
\text { nwt }\end{array}$ & $\begin{array}{c}\mathrm{CACH} \text { 5.SNL } \\
120 \\
71 \mathrm{~A} \\
\mathrm{Tt} \\
\mathrm{nW}\end{array}$ & $\begin{array}{c}\mathrm{CRCH}-6 . \mathrm{SNL} \\
121 \\
T 11 \\
T 1 \\
n W t\end{array}$ & $\begin{array}{c}\mathrm{CRCH} \cdot 7 \cdot \mathrm{SNL} \\
122 \\
71 \mathrm{~A} \\
\mathrm{Tht} \\
\mathrm{nWt}\end{array}$ \\
\hline $\begin{array}{l}\text { Major Altaration } 3 \\
\text { Minor Altoration }\end{array}$ & $K_{1}, \underset{K_{a}}{2 m, ~ O p}$ & $K_{1}, z_{k}, O p$ & $\mathrm{KI}_{\mathrm{I}} \underset{\mathrm{Ka}}{\mathbf{Z} \mathrm{m}} \mathrm{Op}$ & $K 1, Z m, O p$ & $K \mathfrak{K}, \mathrm{Zm}, \mathrm{Op}_{\mathrm{p}}$ & $\begin{array}{l}\mathrm{KI}, \mathrm{Op} \\
\mathrm{Zm}, \mathrm{Ka}\end{array}$ & $\begin{array}{c}\mathrm{KI}_{1}, \mathrm{Zm} \\
\mathrm{Ka}\end{array}$ \\
\hline \multicolumn{8}{|c|}{ 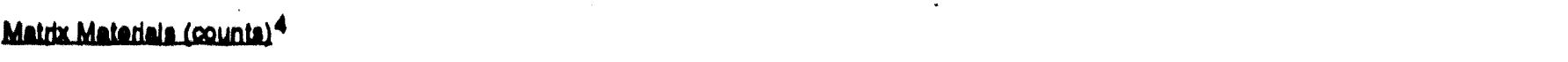 } \\
\hline $\begin{array}{l}\text { Oroundmases } \\
\text { Uthles } \\
\text { Volds }>30 \mu\end{array}$ & $\begin{array}{c}10276 \\
310 \\
300\end{array}$ & $\begin{array}{l}8973 \\
1079 \\
648\end{array}$ & $\begin{array}{c}10062 \\
764 \\
152\end{array}$ & $\begin{array}{l}6774 \\
206 \\
504\end{array}$ & $\begin{array}{r}4620 \\
512 \\
400\end{array}$ & $\begin{array}{l}5956 \\
904 \\
554\end{array}$ & $\begin{array}{l}5076 \\
690 \\
1004\end{array}$ \\
\hline 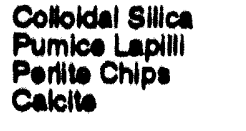 & $\frac{\overline{n d}}{230}$ & $\frac{\overline{n d}}{12}$ & $\frac{\overline{n d}}{110}$ & $\frac{\overline{2946}}{\overline{146}}$ & $\begin{array}{l}4 \overline{810} \\
70 \\
62\end{array}$ & $\begin{array}{l}4 \overline{4106} \\
100 \\
44\end{array}$ & $\begin{array}{l}4 \overline{460} \\
50 \\
18\end{array}$ \\
\hline \multicolumn{8}{|c|}{ Ehenocarente (oountes) } \\
\hline 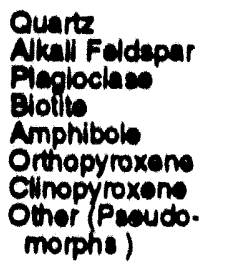 & $\begin{array}{l}25 \\
34 \\
42 \\
4 \\
= \\
\frac{1}{14}\end{array}$ & $\begin{array}{l}63 \\
64 \\
154 \\
\frac{1}{2} \\
= \\
\frac{2}{2}\end{array}$ & $\begin{array}{l}41 \\
50 \\
63 \\
2 \\
= \\
5\end{array}$ & $\begin{array}{l}72 \\
30 \\
72 \\
11 \\
= \\
= \\
=\end{array}$ & $\begin{array}{l}49 \\
91 \\
98 \\
5 \\
\frac{7}{1}\end{array}$ & $\begin{array}{l}40 \\
67 \\
62 \\
6 \\
= \\
= \\
4\end{array}$ & $\begin{array}{l}43 \\
62 \\
65 \\
1 \\
= \\
\frac{1}{2}\end{array}$ \\
\hline \multicolumn{8}{|c|}{ Accenseox Minerele (countes ${ }^{6}$} \\
\hline 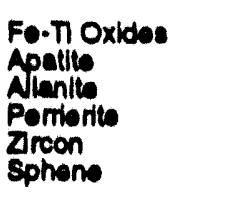 & $\begin{array}{l}\frac{6}{ \pm} \\
=\end{array}$ & $\frac{p}{p}$ & $\frac{p}{p}$ & $\begin{array}{l}\underline{p} \\
\underline{ }\end{array}$ & $\frac{11}{\frac{1}{p}}$ & $\frac{4}{\frac{1}{p}}$ & $\frac{2}{\frac{2}{p}}$ \\
\hline Total Counts & 11241 & 10909 & 11249 & 10761 & 10733 & 12117 & 11773 \\
\hline Remarks & $\begin{array}{l}\text { Adularia } \\
\text { overgrowth on } \\
\text { plagioclase } \\
\text { phenocrysts }\end{array}$ & $\begin{array}{l}\text { Mafic Proudo. } \\
\text { morphs: } \\
\text { allored } \\
\text { opaques }\end{array}$ & $\begin{array}{l}\text { Mafic Peoudo. } \\
\text { morpha: } \\
\text { altored } \\
\text { opaques }\end{array}$ & $\begin{array}{l}\text { Altored } \\
\text { opeques }\end{array}$ & $\begin{array}{l}\text { Mafic Proudo. } \\
\text { morpha: } \\
\text { allored } \\
\text { opaques }\end{array}$ & $\begin{array}{l}\text { Maflc Psoudo. } \\
\text { morphe: } \\
\text { socondary } \\
\text { opaques }\end{array}$ & $\begin{array}{l}\text { Pyroxeno (?); } \\
\text { opcondary } \\
\text { opaques (?) }\end{array}$ \\
\hline
\end{tabular}

Denenocrual summax?

x Phenocryats

Rel. \% Quartz

Rol. $\%$ Ak. Fold.

Rel. * Plag.

1.1
25
34
42

1.1

34

$\begin{array}{ll}2.6 & 1.4 \\ 22 & 27 \\ 23 & 32 \\ 55 & 41\end{array}$

1.7
41
17
41

2.4
21
39
41

1.5
24
40
37

1.5
25
36
38 
APPENDIX A. (cont)

Calloo Hills Area (E.W Lateral Section) Cont.

Fiold Number
LANL Number
Split Number
Geol. Unit'
Uthology

Major Altoration 3 Minor Alteration 3

CRCH-8-SNL
123
TiA
Tht
nwt

$K I, Z c, Z m, O p$, $\mathrm{Ka}$

CRCH.O-SNL
124
T1A
Thi
nwt

$K i, 2 m, O p$, $\mathrm{Zc}, \mathrm{Ka}$
CRCH.10-SNL
125
T1A
Tht
nWt

$\mathrm{KI}, \mathrm{Zc}, \mathrm{Zm}, \mathrm{Op}$,

$\mathrm{Ka}$

Matrix Materiale (counte) ${ }^{4}$

Groundmases
Uthice
Volde $>30 \mu$
Colloidel Sillea
Pumice Laplill
Perlite Chips
Calolte

9816

\section{Phenosryate (counte)}

Quartz
Alkall Foldeper
Plagloclase
Blodto
Amphlbole
Orthopyroxene
Cllnopyroxene
Other (Psoudo-
morphs)

142
161
112
1
$=$
$=$

105
66
132
$=$
$=$
$\overline{5}$

\section{Accessery Minerale (countes) ${ }^{6}$}

\section{Fo-TI Oxides \\ Apatito \\ Allanito \\ Perrierite \\ Zroon \\ Sphene}

Total Counts

\section{$\frac{9}{2}$}

10688

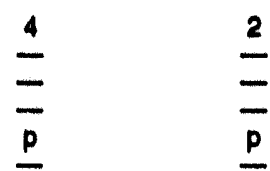

11163

9372

Remarks

$\begin{array}{ccc}\text { Fo-Mn oxides (?); } & \text { Mafic Proudo- } & \text { Mafic Psoudo- } \\ \text { secondary } & \text { morphs; } & \text { morphs; } \\ \text { opaques (?) } & \text { socondary } & \text { socondary } \\ \text { opaques } & \text { opaques }\end{array}$

\section{Phenocryat Summax ${ }^{7}$}

$\%$ Phenocrysts

Rol. \% Quartz

Rol. \% Alk. Fold.

Rel \% Plag.

Rel \% Plas

\begin{tabular}{lll}
4.0 & 2.8 & 1.0 \\
34 & 35 & 39 \\
39 & 22 & 33 \\
27 & 44 & 28 \\
\hline
\end{tabular}

Geol Unit: $T c p=$ Prow Pass Member, $T w \mid=$ Wahmonie Formution (lower part), $T h t=$ tuffaceous beds of Calico Hills, $T p t=$

Topopah Spring Member, $T p p=P a h$ Canyon Member, $T f d=$ thyolite of Delirium Canyon, $T$ to $=$ thyolite of Black Glass Canyon.

2 Lithology: nwt = nonwelded tuff, mostly pyroclastic flows but may include massive ash-fall and reworked tuffs; pwt = partially. welded ash-flow tuff; $m w t=$ moderately-welded ash-flow tuff; $n=$ vitrophyric tuff; $b=$ bedded tuff, individual beds characterized by internal stratification.

3 Major and Minor Alteration: $\mathrm{Gl}=$ glassy, $\mathrm{Zc}=$ clinoptilolite zeolites, $\mathrm{Zm}=$ mordenite zeolites, $\mathrm{Sm}=$ smectite, Op $=$ opal.CT, $\mathrm{Kf}=$ adularia, $K_{a}=$ kaolinite, $C_{x}=$ post-emplacement, high-temperature crystallization.

${ }^{4}$ Numbers in columns indicate the number of times these matrix materials and phenocrysts were hit in the point count; $p=$ present but not hit during point counted; nd $=$ not determined; $-=$ not present.

5 Includes both shards and pumice in samples where punice is not counted separalely.

6 For Fe-Ti oxides, numbers in columns indicate the number of times these minerals were hit in the point count; for all other accessory minerals, the number in the columns is a tally of all grains seen in thin section; $p=$ present but not hit during point count or counted es part of tally; $-=$ not present.

7 Relative percents are percents of felsic phenocrysts (quartz + alkali feldspar + plagioclase) 


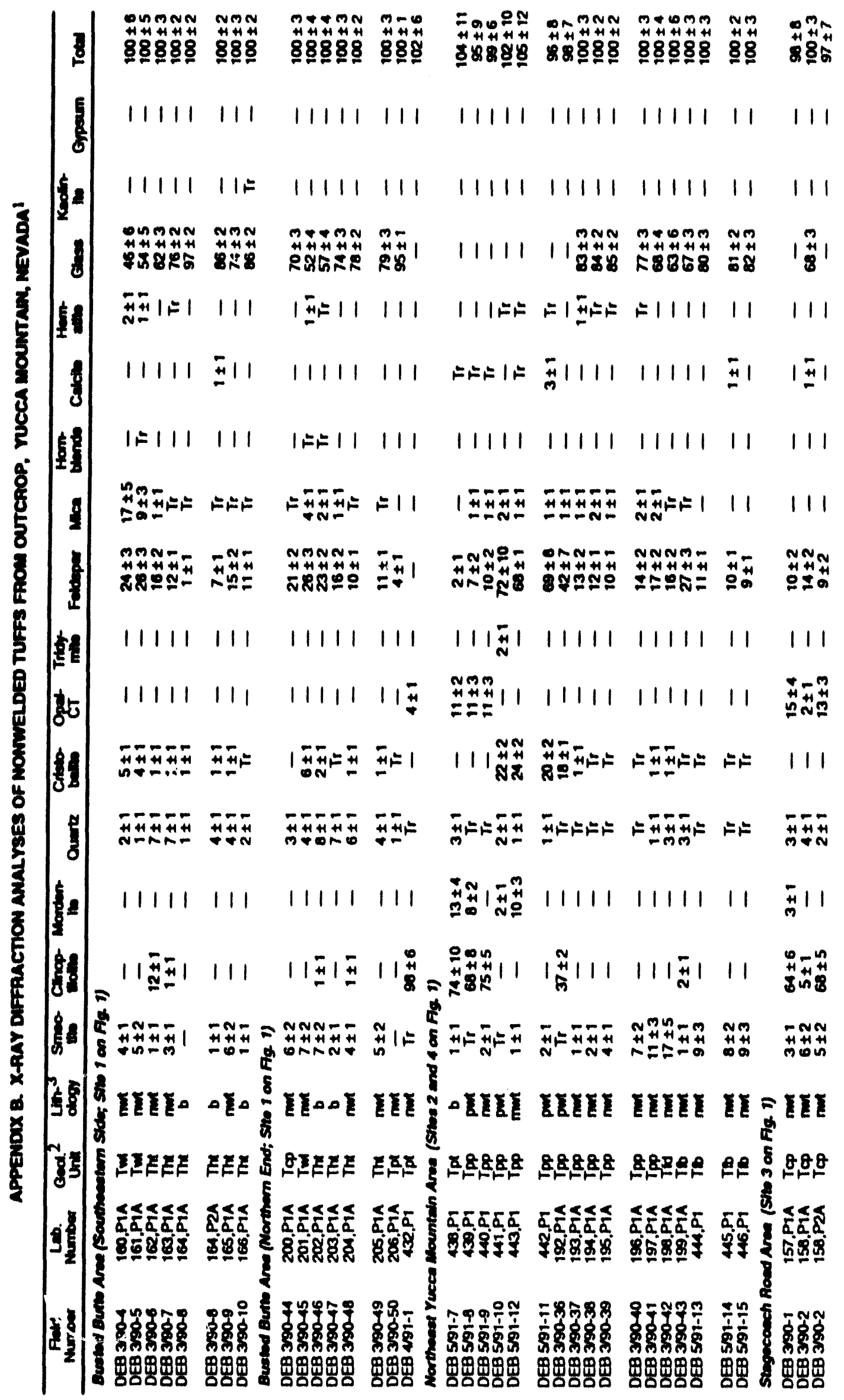




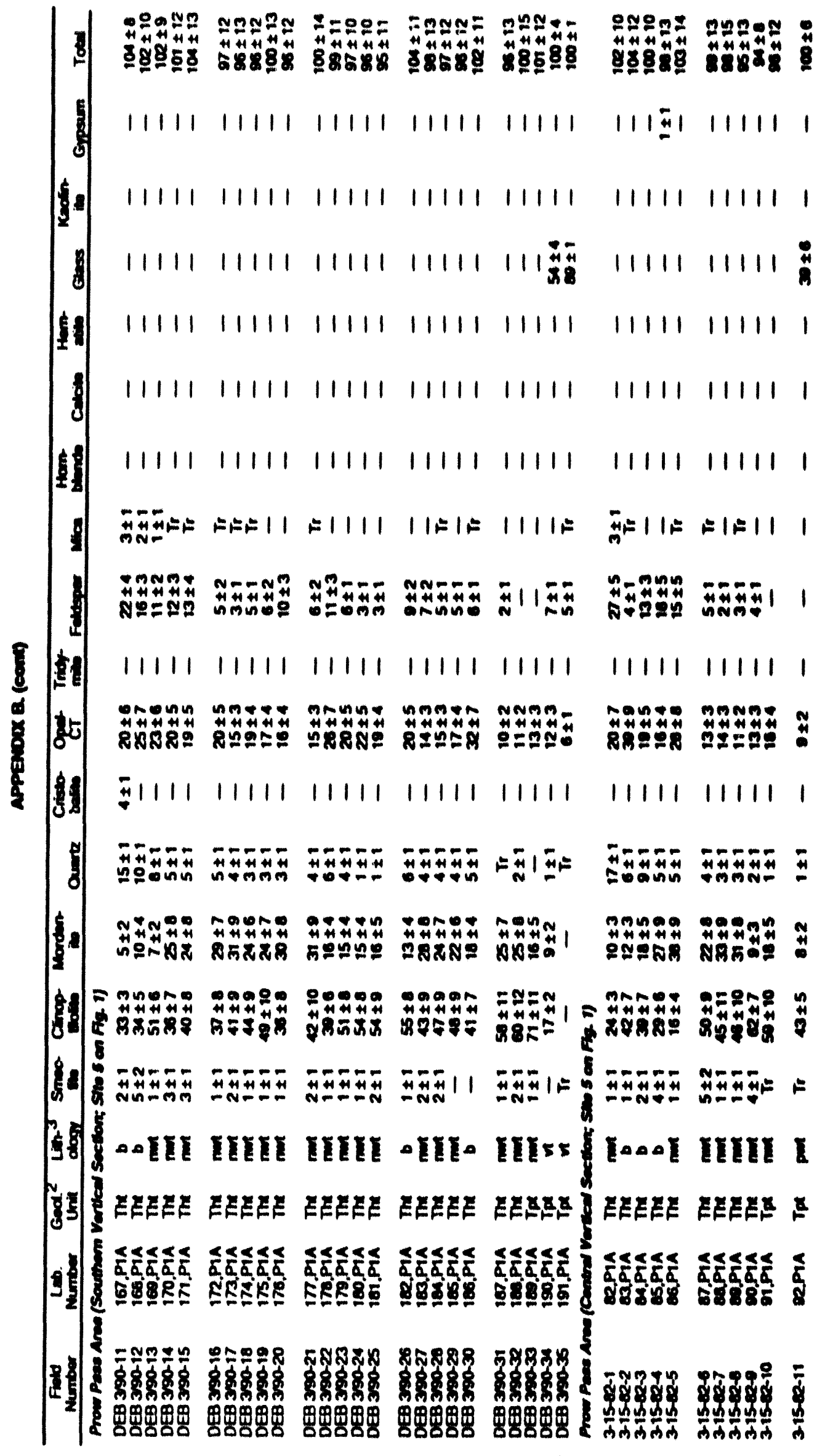




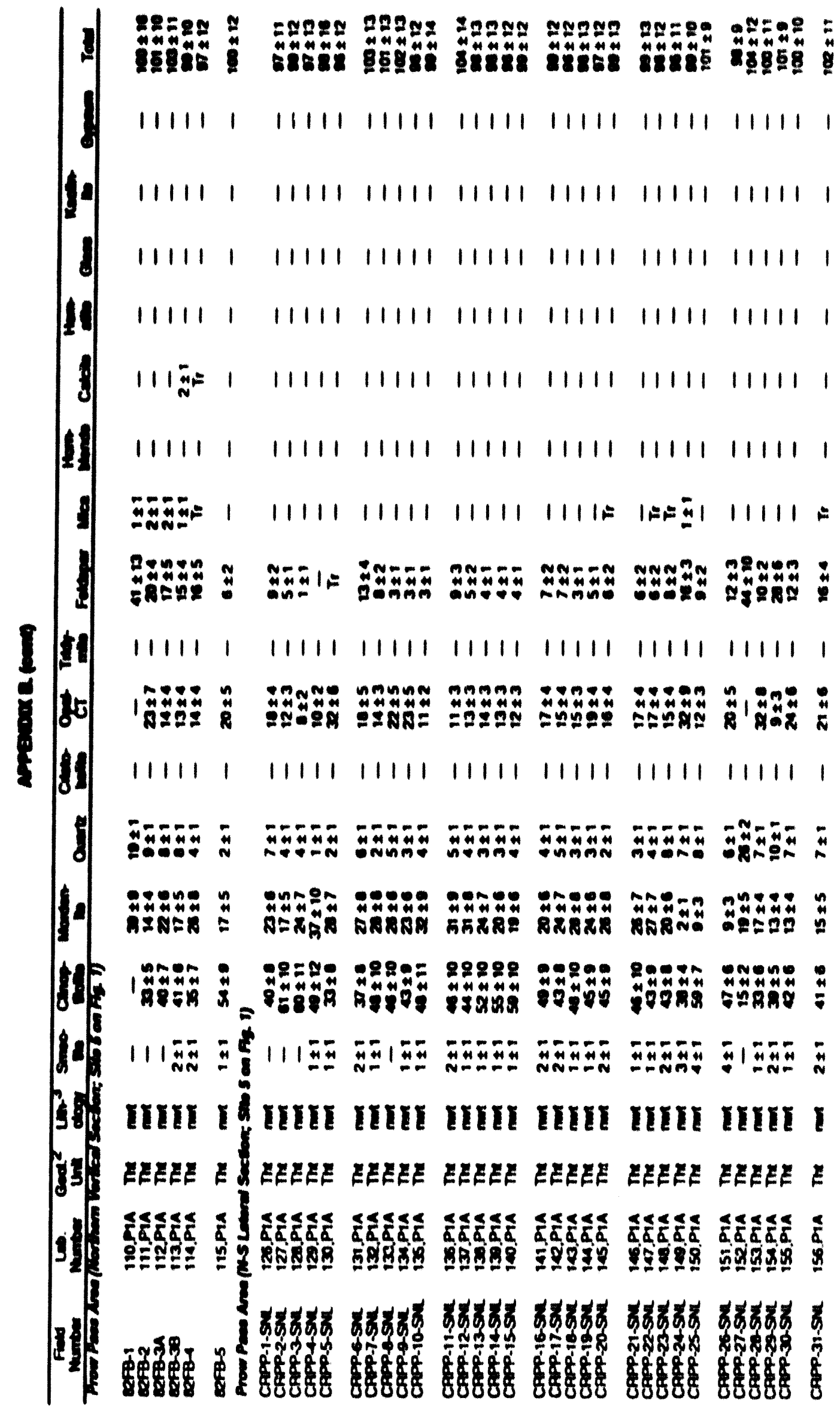




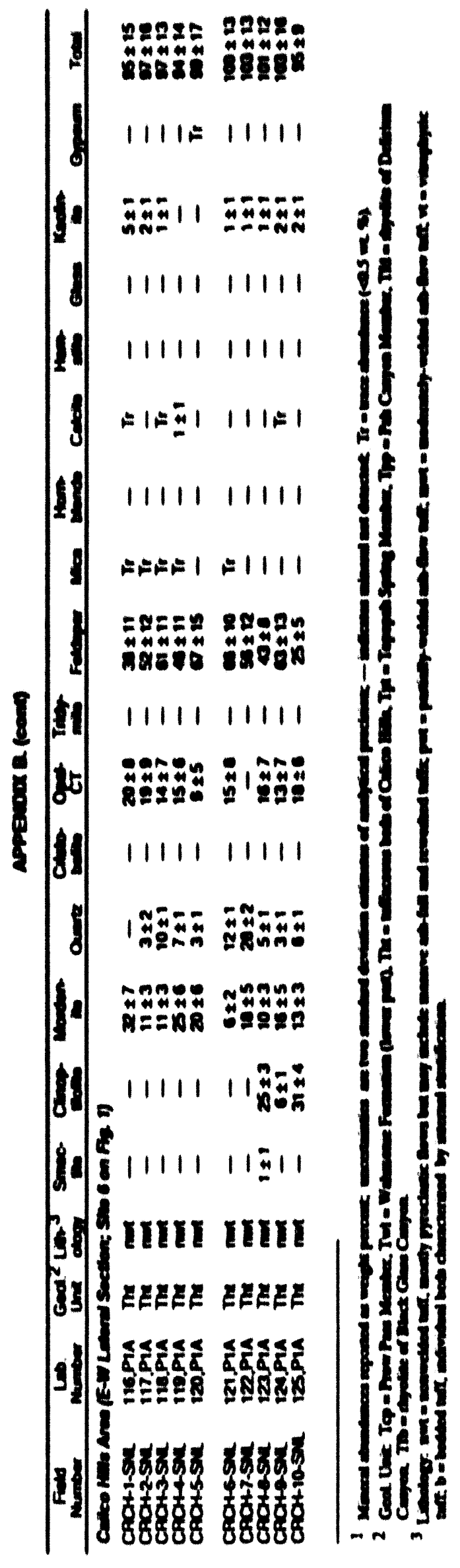


APPENDIX C. MAJOR. ANO TAACE.ELEMENT ANALYGES OF NONWELDED TUFFS FROM OUTCROP, YUCCA MOUNTAN, NEVAOA

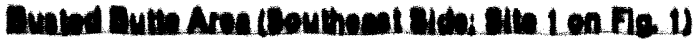

\begin{tabular}{|c|c|c|c|c|c|c|c|c|}
\hline 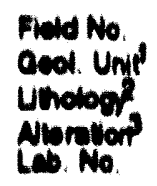 & 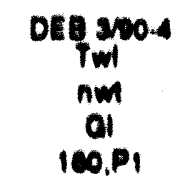 & 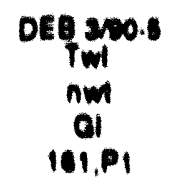 & $\begin{array}{c}\text { Deg yoos } \\
\text { Thi } \\
\text { nwi } \\
\text { O1. } 20 \\
\text { IA2,P! }\end{array}$ & $\begin{array}{c}\text { OEg } 300.7 \\
\text { Thi } \\
n m \\
\text { al } \\
109 . p_{1}\end{array}$ & $\begin{array}{c}\text { DEE } 3 / 20.0 \\
\text { Thi } \\
b \\
\text { OI } \\
\text { IEA.P1 }\end{array}$ & $\begin{array}{c}\text { DEg } 3 \times 0 \cdot 0 \\
\text { Th! } \\
b \\
a ! \\
184, P 2\end{array}$ & $\begin{array}{c}\text { Deg } 300.0 \\
\text { Thi } \\
n m \\
\text { al } \\
\text { IEs,PI }\end{array}$ & $\begin{array}{c}\text { DEO 3Co.10 } \\
\text { Thi } \\
\text { b } \\
\text { O! } \\
\text { IES,P1 }\end{array}$ \\
\hline \multicolumn{9}{|c|}{ Whr and A A Rooune (mis) } \\
\hline & 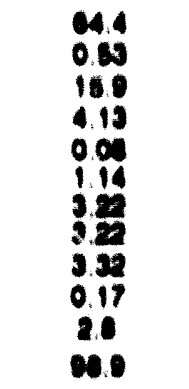 & $\begin{array}{l}142 \\
0.81 \\
100 \\
1.00 \\
0.07 \\
187 \\
3.77 \\
3.20 \\
3.17 \\
0.10 \\
2.0 \\
0.3\end{array}$ & $\begin{array}{l}72.3 \\
0.10 \\
12.8 \\
1.00 \\
0.07 \\
0.40 \\
18 \\
2.40 \\
470 \\
0.11 \\
41 \\
1003\end{array}$ & $\begin{array}{l}732 \\
0.10 \\
12.7 \\
110 \\
0.00 \\
0.80 \\
0.04 \\
300 \\
140 \\
0.00 \\
30 \\
1004\end{array}$ & $\begin{array}{l}700 \\
0.00 \\
100 \\
0.4 \\
0.04 \\
0.10 \\
0.95 \\
2.10 \\
4.70 \\
0.07 \\
3.0 \\
1000\end{array}$ & $\begin{array}{l}74.0 \\
0.00 \\
110 \\
0.93 \\
0.04 \\
0.90 \\
1.07 \\
2.00 \\
1.70 \\
0.07 \\
1.0 \\
000\end{array}$ & $\begin{array}{l}72.8 \\
0.18 \\
12.8 \\
1.11 \\
0.07 \\
0.49 \\
0.80 \\
2.84 \\
4.43 \\
0.07 \\
4.7 \\
100.2\end{array}$ & $\begin{array}{l}73.1 \\
0.13 \\
12 . \\
1.26 \\
0.00 \\
0.32 \\
0.70 \\
274 \\
1.72 \\
0.07 \\
4.2 \\
100.1\end{array}$ \\
\hline & $\begin{array}{l}1370 \\
812\end{array}$ & 160 & 297 & $\begin{array}{l}770 \\
138\end{array}$ & 100 & $\begin{array}{l}118 \\
87\end{array}$ & 130 & $\begin{array}{l}110 \\
4\end{array}$ \\
\hline \multicolumn{9}{|c|}{ 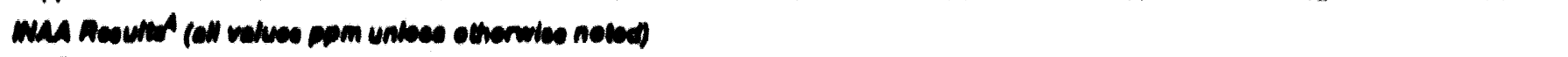 } \\
\hline $\begin{array}{l}\theta_{0}(k) \\
0(k) \\
0(k)\end{array}$ & 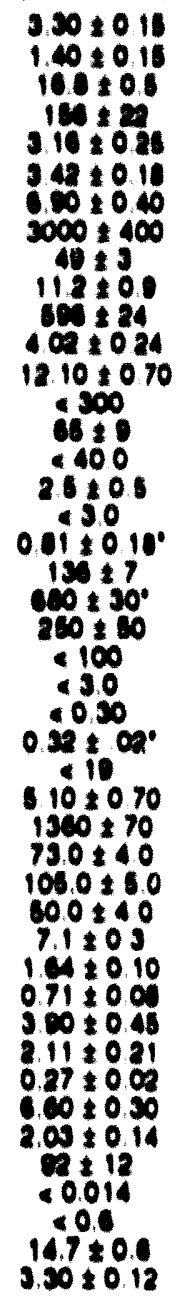 & 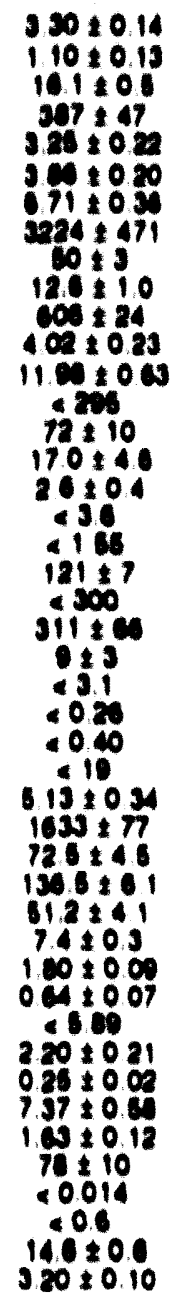 & 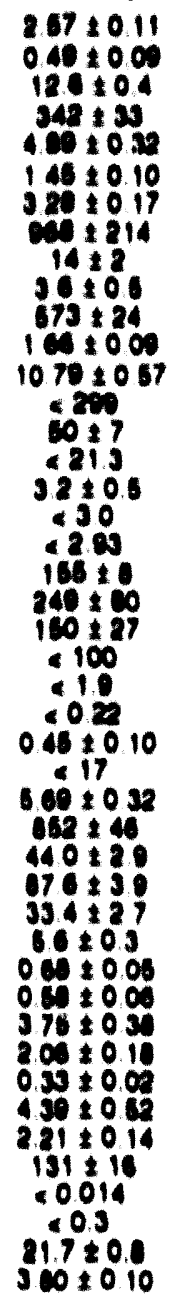 & 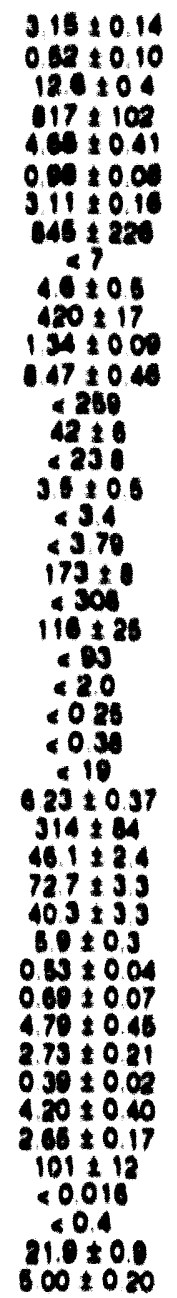 & 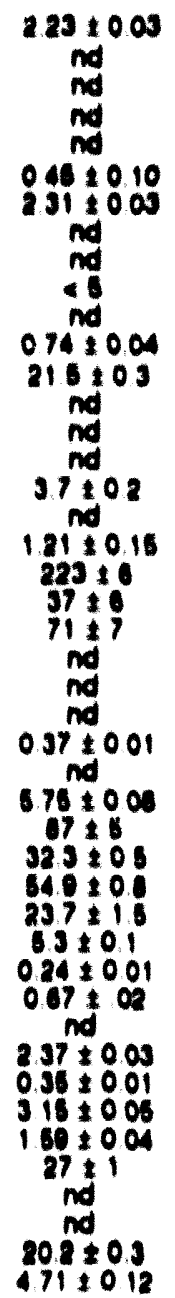 & 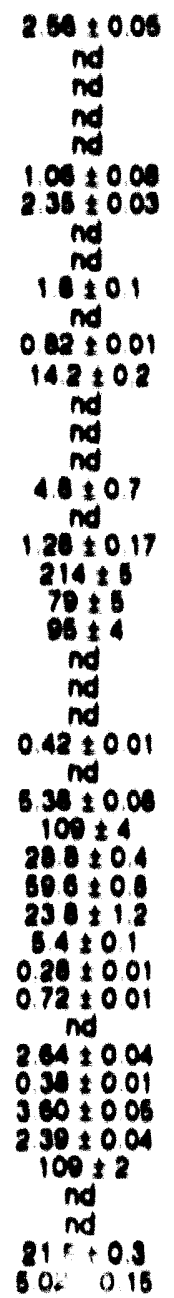 & 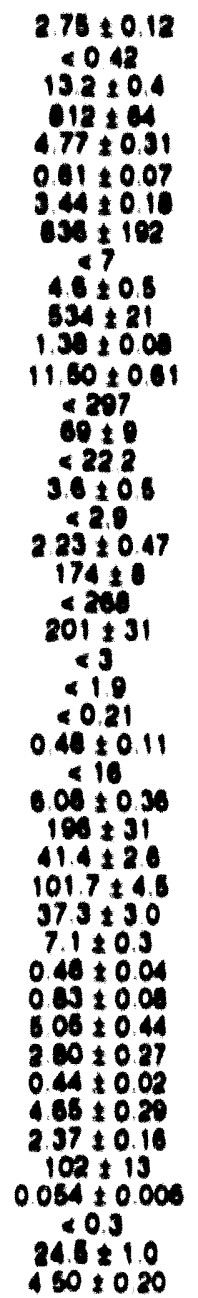 & 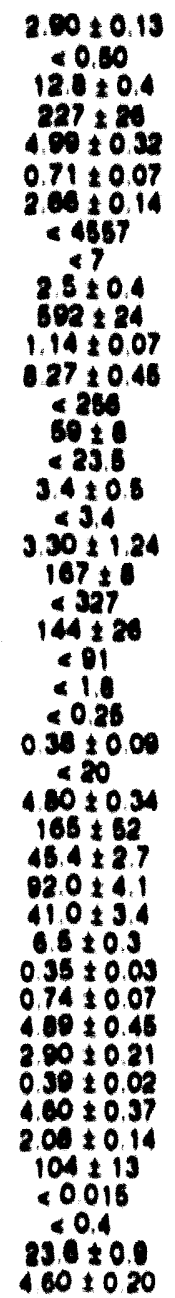 \\
\hline
\end{tabular}


APPENDIX C. (cont)

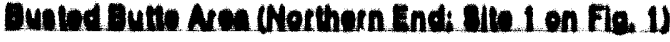

\begin{tabular}{|c|c|c|c|c|c|c|c|c|}
\hline $\begin{array}{l}\text { Fiold No } \\
\text { Oeol Unif } \\
\text { Ltholog? } \\
\text { Nioretion? } \\
\text { Lab No }\end{array}$ & $\begin{array}{c}\text { DED } 300.44 \\
\text { TCP } \\
n \mathrm{nW} \\
01 \\
200 . \mathrm{Pl}\end{array}$ & $\begin{array}{c}\text { DEB 3/eo-46 } \\
\text { Twi } \\
n w 1 \\
O 1 \\
201, P 1\end{array}$ & $\begin{array}{c}\text { DEB } 3 / 00-40 \\
\text { Tw1 } \\
b \\
01 \\
202, P 1\end{array}$ & $\begin{array}{c}\text { DED } 300 \cdot 47 \\
\text { thi } \\
\text { b } \\
\text { al } \\
203, \mathrm{Pl}\end{array}$ & 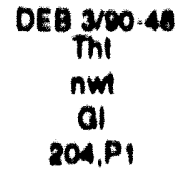 & $\begin{array}{c}\text { OEt } 3 * 0.40 \\
\text { Thi } \\
n w 1 \\
\text { QI } \\
205, P_{1}\end{array}$ & $\begin{array}{c}\text { DEB } \underset{T p 0}{T p 1} \\
\operatorname{nm}_{01} \\
205, P 1\end{array}$ & $\begin{array}{c}\text { DEg } \\
\text { TPI } \\
n_{n W 1} \\
20 \\
432, P 1\end{array}$ \\
\hline \multicolumn{9}{|c|}{ XAF and AA Rooulto (wh) } \\
\hline 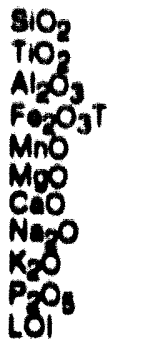 & $\begin{array}{l}72.0 \\
0.10 \\
12.8 \\
1.32 \\
0.08 \\
0.28 \\
1.08 \\
2.28 \\
1.20 \\
0.00 \\
1.0\end{array}$ & $\begin{array}{l}01.0 \\
0.40 \\
18.2 \\
1.01 \\
0.10 \\
1.34 \\
1.20 \\
2.65 \\
2.44 \\
0.10 \\
7.1\end{array}$ & $\begin{array}{l}08.5 \\
0.27 \\
14.2 \\
2.32 \\
0.00 \\
0.70 \\
2.9 \\
2.73 \\
3.10 \\
0.11 \\
6.1\end{array}$ & $\begin{array}{l}74.1 \\
0.15 \\
11.9 \\
1.31 \\
0.05 \\
0.44 \\
1.12 \\
2.01 \\
1.48 \\
0.10 \\
3.4\end{array}$ & $\begin{array}{l}72.7 \\
0.18 \\
12.7 \\
1.90 \\
0.00 \\
0.81 \\
1.00 \\
2.75 \\
4.97 \\
0.04 \\
4.1\end{array}$ & $\begin{array}{l}72.0 \\
0.14 \\
12.4 \\
1.31 \\
0.16 \\
0.38 \\
0.78 \\
2.72 \\
1.89 \\
0.07 \\
4.1\end{array}$ & $\begin{array}{l}73.4 \\
0.11 \\
12.3 \\
1.01 \\
0.00 \\
0.10 \\
0.89 \\
2.00 \\
4.97 \\
0.07 \\
3.7\end{array}$ & $\begin{array}{l}67.0 \\
0.10 \\
11.4 \\
0.15 \\
0.07 \\
0.84 \\
8.80 \\
0.8 \\
3.00 \\
0.01 \\
12.0\end{array}$ \\
\hline & 00.5 & 90 & 900 & 98.7 & 00.0 & 90.4 & 09.3 & 100.0 \\
\hline $\begin{array}{l}\text { 8a ppm } \\
\text { si ppm }\end{array}$ & $\begin{array}{l}233 \\
106\end{array}$ & $\begin{array}{l}1101 \\
702\end{array}$ & $\begin{array}{l}180 \\
100\end{array}$ & $\begin{array}{l}824 \\
158\end{array}$ & $\begin{array}{l}218 \\
110\end{array}$ & $\begin{array}{l}130 \\
70\end{array}$ & $\begin{array}{l}40 \\
16\end{array}$ & 48 \\
\hline \multicolumn{9}{|c|}{ WAA Reoultet (all values ppen unkese othonwioe noted) } \\
\hline 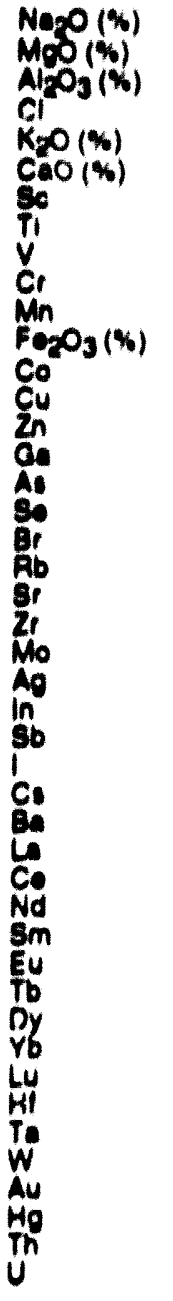 & 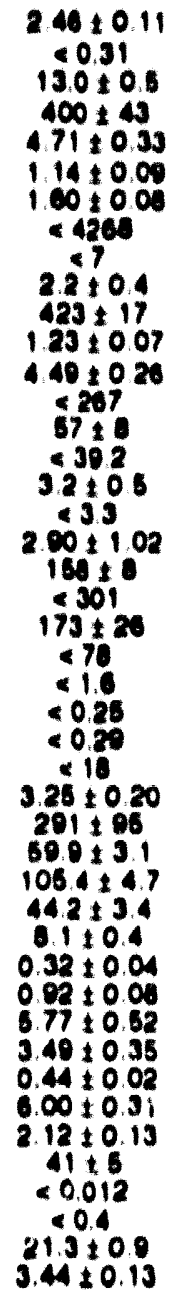 & 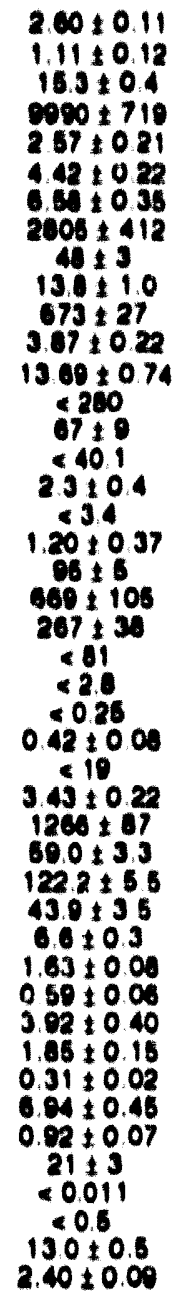 & 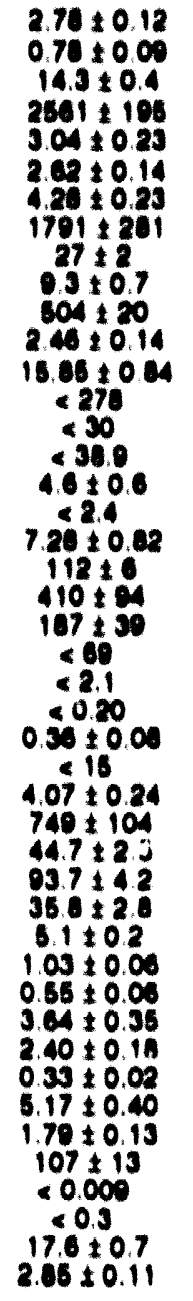 & 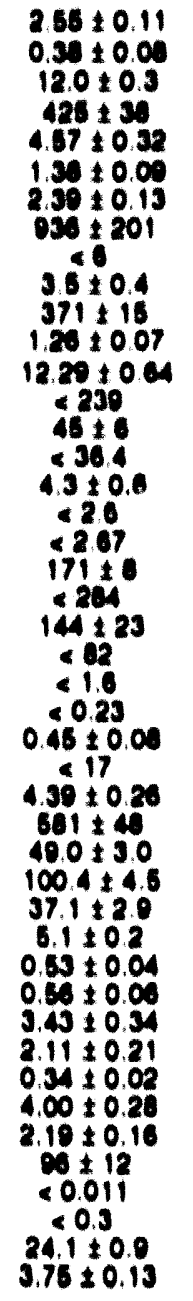 & 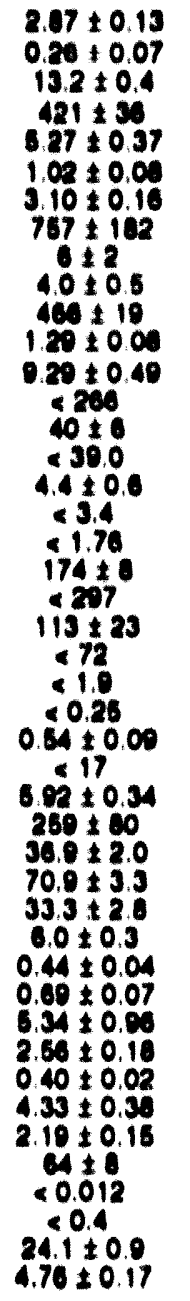 & 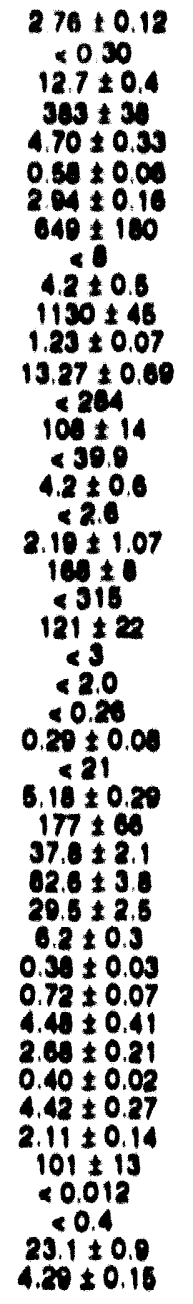 & 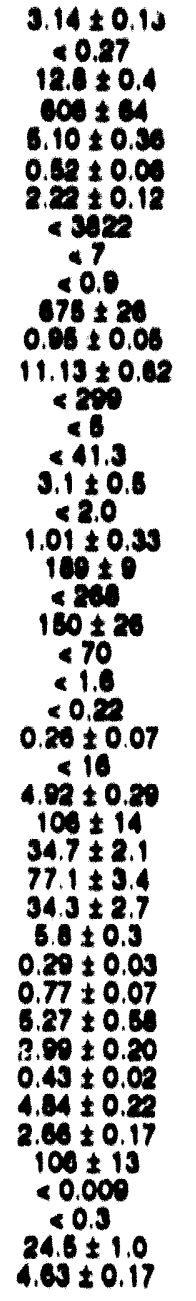 & 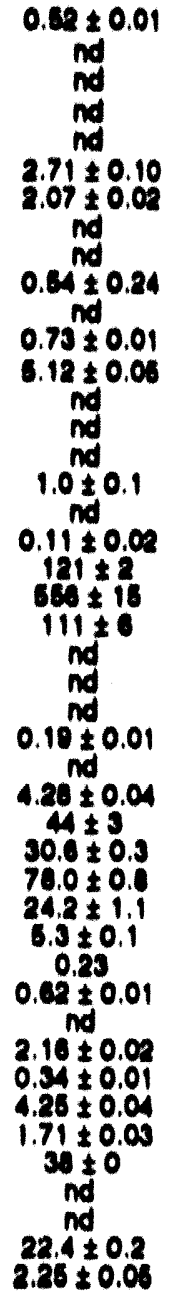 \\
\hline
\end{tabular}


APPENDIX C. (cont)

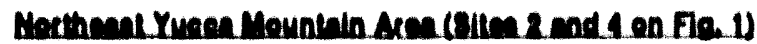

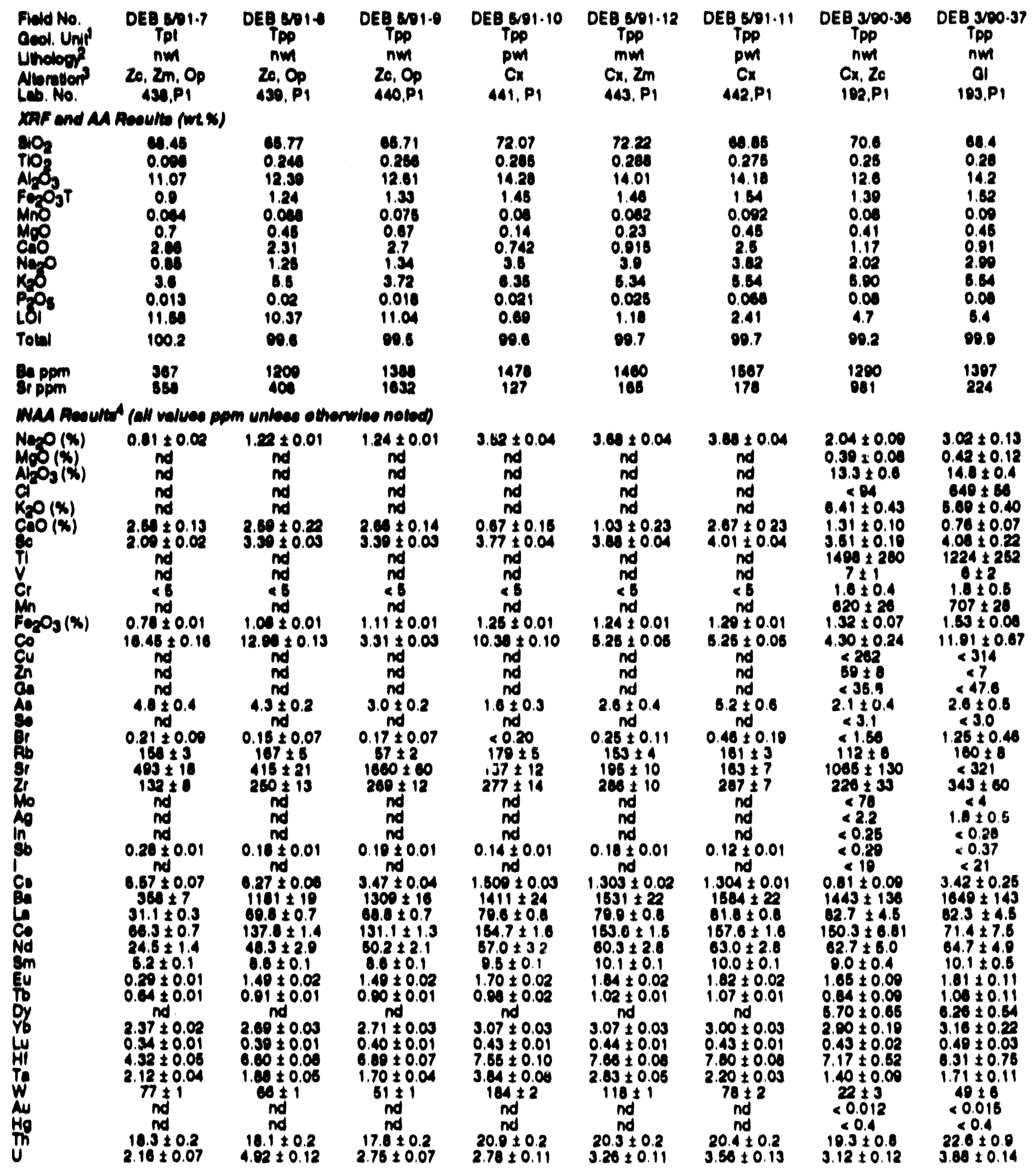


APPENDIX C. (cont)

Northeast Yucca Mountain Area Cont (Sitos 2 and 4 on Flo, 1)

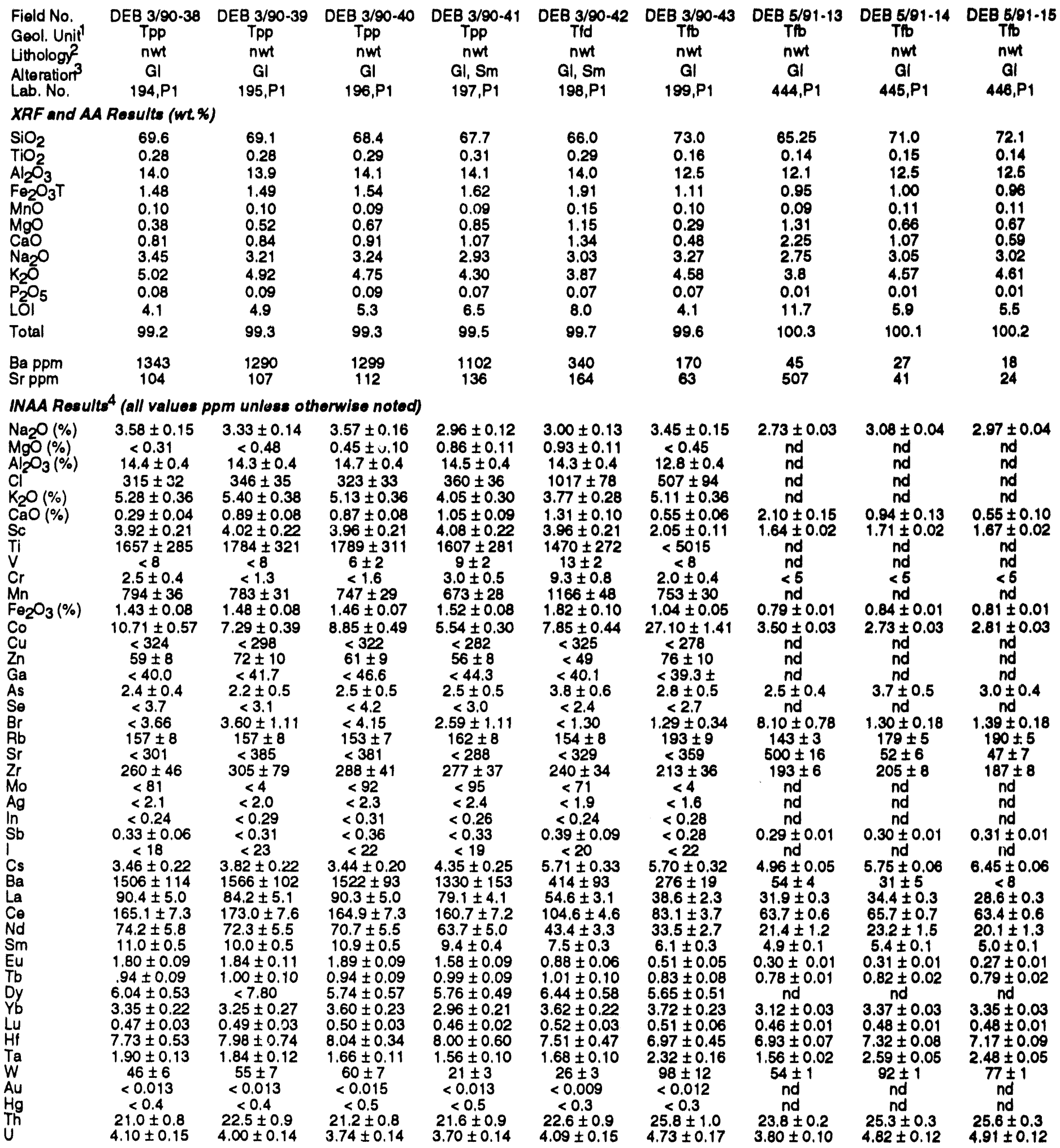


APPENDIX C. (cont)

Singereach Rend (Sile 3 on Fla 1)
Prow Pase Area (Southern Vertlcal Sectlon: Slte $b$ on Ela 11

\begin{tabular}{|c|c|c|c|c|c|c|c|c|c|c|}
\hline $\begin{array}{l}\text { Fiold No. } \\
\text { Gool. Unit' } \\
\text { Lilholog? } \\
\text { Alleration } \\
\text { Lab. No. }\end{array}$ & $\begin{array}{c}\text { OEB 3/90-1 } \\
\text { Tcp } \\
\text { nwt } \\
\text { Zc, Op } \\
157, P_{1}\end{array}$ & $\begin{array}{c}\text { DEB 3/90-2 } \\
\text { TCp } \\
\text { nwt } \\
\text { Gl } \\
\text { 158,P1 }\end{array}$ & $\begin{array}{c}\text { DEB } 3 / 90-2 \\
\text { Tcp } \\
n w 1 \\
\text { Zc, Op } \\
158, P 2\end{array}$ & $\begin{array}{c}\text { DEB } 3 / 90.11 \\
\text { Tht } \\
\text { b } \\
\text { Zc, Op } \\
167, P 1\end{array}$ & $\begin{array}{c}\text { DEB } 390-12 \\
\text { Tht } \\
b \\
2 c, O p \\
168, P 1\end{array}$ & $\begin{array}{c}\text { DEB } 3 / 90.13 \\
\text { Tht } \\
\text { nwt } \\
\text { Zc, Op } \\
169, \mathrm{P1}\end{array}$ & $\begin{array}{c}\text { DEB } 3 / 80-14 \\
\text { Tht } \\
n w t \\
\text { Zc, } Z \mathrm{Zm}, \mathrm{Op} \\
170, \mathrm{P1}\end{array}$ & $\begin{array}{c}\text { DEB } 3 / 90-15 \\
\text { Tht } \\
n w t \\
\text { Zc, } Z \mathrm{~m}, \mathrm{Op} \\
171, \mathrm{Pt}\end{array}$ & $\begin{array}{c}\text { DEB } 3 / 90-16 \\
\text { Tht } \\
\text { nwt } \\
\text { Zc, Zm, Op } \\
172, P 1\end{array}$ & $\begin{array}{c}\text { DEB } 3 / 80.17 \\
\text { Tht } \\
\text { nwt } \\
\text { Zc, } \mathrm{Zm}, \mathrm{Op} \\
173, \mathrm{P1}\end{array}$ \\
\hline \multicolumn{11}{|c|}{$X R F$ and AA Results (wt \%) } \\
\hline $\begin{array}{l}\mathrm{SlO}_{2} \\
\mathrm{TOO}_{2} \\
\mathrm{Al}_{2} \mathrm{O}_{3} \\
\mathrm{Fe}_{2} \mathrm{O}_{3} \mathrm{~T} \\
\mathrm{MnO} \\
\mathrm{MgO} \\
\mathrm{CaO} \\
\mathrm{NaOO} \\
\mathrm{K}_{2} \mathrm{O} \\
\mathrm{P}_{2} \mathrm{O}_{5} \\
\mathrm{LOI}\end{array}$ & $\begin{array}{l}67.5 \\
0.12 \\
12.1 \\
1.33 \\
0.07 \\
0.29 \\
0.65 \\
3.71 \\
4.16 \\
0.07 \\
10.2\end{array}$ & $\begin{array}{l}68.9 \\
0.19 \\
13.1 \\
1.83 \\
0.08 \\
0.60 \\
1.18 \\
3.28 \\
4.20 \\
0.09 \\
6.1\end{array}$ & $\begin{array}{l}67.9 \\
0.11 \\
12.0 \\
1.29 \\
0.06 \\
0.47 \\
0.76 \\
3.12 \\
4.24 \\
0.07 \\
10.0\end{array}$ & $\begin{array}{l}73.4 \\
0.15 \\
11.3 \\
1.31 \\
0.02 \\
0.60 \\
2.16 \\
1.71 \\
2.96 \\
0.07 \\
6.7\end{array}$ & $\begin{array}{l}71.8 \\
0.11 \\
10.9 \\
0.93 \\
0.02 \\
1.49 \\
1.95 \\
1.54 \\
3.20 \\
0.08 \\
8.5\end{array}$ & $\begin{array}{l}70.8 \\
0.11 \\
11.4 \\
0.86 \\
0.03 \\
0.49 \\
1.73 \\
1.24 \\
3.77 \\
0.07 \\
8.0\end{array}$ & $\begin{array}{l}68.5 \\
0.09 \\
11.9 \\
0.97 \\
0.03 \\
0.42 \\
1.69 \\
1.11 \\
5.16 \\
0.07 \\
10.2\end{array}$ & $\begin{array}{l}68.5 \\
0.08 \\
12.0 \\
1.01 \\
0.04 \\
0.48 \\
1.84 \\
1.27 \\
4.47 \\
0.08 \\
10.4\end{array}$ & $\begin{array}{l}69.1 \\
0.08 \\
11.3 \\
0.93 \\
0.04 \\
0.20 \\
1.47 \\
0.59 \\
5.80 \\
0.07 \\
10.0\end{array}$ & $\begin{array}{l}68.7 \\
0.09 \\
11.6 \\
0.93 \\
0.03 \\
0.37 \\
1.91 \\
1.01 \\
4.53 \\
0.08 \\
11.2\end{array}$ \\
\hline & 100.1 & 99.6 & 100.0 & 100.4 & 100.4 & 89.6 & 100.1 & 100.3 & 89.6 & 100.4 \\
\hline $\begin{array}{l}\text { Ba ppm } \\
\text { Sr ppm }\end{array}$ & $\begin{array}{l}187 \\
288\end{array}$ & $\begin{array}{l}183 \\
271\end{array}$ & $\begin{array}{l}191 \\
777\end{array}$ & $\begin{array}{l}451 \\
292\end{array}$ & $\begin{array}{l}393 \\
202\end{array}$ & $\begin{array}{c}307 \\
93\end{array}$ & $\begin{array}{l}122 \\
85\end{array}$ & $\begin{array}{l}110 \\
100\end{array}$ & $\begin{array}{l}111 \\
112\end{array}$ & $\begin{array}{c}84 \\
130\end{array}$ \\
\hline \multicolumn{11}{|c|}{ INAA Result' (all values ppm uniless otherwlse noted) } \\
\hline $\begin{array}{l}\mathrm{Na} O(\%) \\
\mathrm{MOO}_{(\%)} \\
\mathrm{Al} \mathrm{O}_{3}(\%) \\
\mathrm{Cl} \\
\mathrm{K} \mathrm{O}(\%) \\
\mathrm{CaO}(\%) \\
\mathrm{Sc} \\
\mathrm{T} \\
\mathrm{V} \\
\mathrm{Cr} \\
\mathrm{Mn} \\
\mathrm{Fe} \mathrm{O}_{3}(\%) \\
\mathrm{Co} \\
\mathrm{Cu}\end{array}$ & $\begin{array}{c}3.91 \pm 0.16 \\
<0.31 \\
12.5 \pm 0.4 \\
<154 \\
4.18 \pm 0.28 \\
0.33 \pm 0.05 \\
1.74 \pm 0.09 \\
<4789 \\
<8 \\
1.8 \pm 0.5 \\
542 \pm 24 \\
1.23 \pm 0.07 \\
3.86 \pm 0.25 \\
<329 \\
64 \pm 9 \\
<30.5 \\
2.5 \pm 0.5 \\
<3.5 \\
<3.91 \\
143 \pm 7 \\
<309 \\
117 \pm 22 \\
<111 \\
<1.8 \\
<0.29 \\
1.22 \pm 0.16 \\
<20 \\
4.86 \pm 0.28 \\
284 \pm 46 \\
38.7 \pm 2.2 \\
93.6 \pm 4.3 \\
31.3 \pm 2.8 \\
4.7 \pm 0.2 \\
0.24 \pm 0.04 \\
0.53 \pm 0.05 \\
3.52 \pm 0.37 \\
2.38 \pm 0.26 \\
0.28 \pm 0.02 \\
5.76 \pm 0.44 \\
2.03 \pm 0.14 \\
42 \pm 5 \\
<0.016 \\
<0.4 \\
19.9 \pm 0.8 \\
4.00 \pm 0.10\end{array}$ & $\begin{array}{c}3.31 \pm 0.14 \\
0.58 \pm 0.09 \\
13.6 \pm 0.4 \\
391 \pm 37 \\
4.46 \pm 0.29 \\
1.29 \pm 0.10 \\
3.32 \pm 0.18 \\
1205 \pm 235 \\
15 \pm 2 \\
15.2 \pm 1.1 \\
624 \pm 26 \\
1.79 \pm 0.09 \\
9.32 \pm 0.49 \\
<328 \\
181 \pm 23 \\
<24.5 \\
3.9 \pm 0.5 \\
<3.1 \\
<1.98 \\
151 \pm 7 \\
402 \pm 111 \\
227 \pm 32 \\
<113 \\
<2.0 \\
<0.24 \\
<0.38 \\
<18 \\
9.26 \pm 0.52 \\
299 \pm 46 \\
52.2 \pm 3.1 \\
112.1 \pm 5.0 \\
43.0 \pm 3.3 \\
8.6 \pm 0.4 \\
0.42 \pm 0.05 \\
1.13 \pm 0.11 \\
6.74 \pm 0.61 \\
3.94 \pm 0.27 \\
0.56 \pm 0.03 \\
6.27 \pm 0.44 \\
2.39 \pm 0.16 \\
73 \pm 8 \\
<0.017 \\
<0.4 \\
21.8 \pm 0.8 \\
3.70 \pm 0.10\end{array}$ & $\begin{array}{c}3.23 \pm 0.14 \\
0.44 \pm 0.08 \\
12.3 \pm 0.3 \\
<114 \\
4.63 \pm 0.30 \\
0.66 \pm 0.07 \\
1.61 \pm 0.09 \\
<4113 \\
9 \pm 2 \\
3.2 \pm 0.4 \\
485 \pm 19 \\
1.18 \pm 0.07 \\
4.73 \pm 0.26 \\
<245 \\
47 \pm 7 \\
<22.1 \\
3.4 \pm 0.5 \\
<2.8 \\
<3.44 \\
87 \pm 4 \\
883 \pm 100 \\
135 \pm 21 \\
<86 \\
<1.4 \\
<0.24 \\
<0.35 \\
<18 \\
6.32 \pm 0.36 \\
237 \pm 50 \\
37.1 \pm 2.0 \\
77.7 \pm 3.5 \\
25.2 \pm 2.0 \\
4.8 \pm 0.2 \\
0.26 \pm 0.03 \\
0.58 \pm 0.07 \\
4.01 \pm 0.38 \\
1.83 \pm 0.18 \\
0.31 \pm 0.02 \\
5.31 \pm 0.32 \\
1.79 \pm 0.12 \\
45 \pm 5 \\
<0.015 \\
<0.3 \\
19.5 \pm 0.7 \\
2.40 \pm 0.10\end{array}$ & $\begin{array}{c}1.78 \pm 0.07 \\
0.50 \pm 0.05 \\
11.4 \pm 0.3 \\
<82 \\
2.88 \pm 0.19 \\
2.40 \pm 0.14 \\
1.88 \pm 0.10 \\
870 \pm 170 \\
7 \pm 1 \\
4.2 \pm 0.4 \\
157 \pm 7 \\
1.19 \pm 0.06 \\
12.93 \pm 0.69 \\
<218 \\
40 \pm 7 \\
<20.7 \\
1.4 \pm 0.3 \\
<2.6 \\
<1.41 \\
93 \pm 5 \\
354 \pm 68 \\
147 \pm 25 \\
<90 \\
<2.0 \\
<0.20 \\
<0.31 \\
<13 \\
4.01 \pm 0.24 \\
593 \pm 55 \\
34.2 \pm 2.0 \\
63.3 \pm 3.0 \\
24.0 \pm 2.1 \\
4.3 \pm 0.2 \\
0.65 \pm 0.04 \\
0.42 \pm 0.05 \\
2.69 \pm 0.31 \\
1.82 \pm 0.18 \\
0.24 \pm 0.02 \\
3.84 \pm 0.36 \\
2.57 \pm 0.16 \\
136 \pm 17 \\
<0.013 \\
0.6 \pm 0.2 \\
14.9 \pm 0.6 \\
2.60 \pm 0.10\end{array}$ & $\begin{array}{c}1.65 \pm 0.07 \\
1.26 \pm 0.08 \\
10.8 \pm 0.3 \\
583 \pm 47 \\
3.32 \pm 0.22 \\
1.77 \pm 0.12 \\
1.85 \pm 0.10 \\
<3205 \\
<6 \\
2.1 \pm 0.4 \\
194 \pm 8 \\
0.85 \pm 0.05 \\
6.28 \pm 0.34 \\
<209 \\
38 \pm 5 \\
<20.0 \\
2.3 \pm 0.4 \\
<2.5 \\
4.48 \pm 0.57 \\
117 \pm 6 \\
<200 \\
113 \pm 23 \\
<3 \\
<1.5 \\
<0.19 \\
0.43 \pm 0.09 \\
<14 \\
5.88 \pm 0.34 \\
540 \pm 29 \\
33.4 \pm 1.8 \\
64.5 \pm 2.8 \\
27.4 \pm 2.3 \\
4.0 \pm 0.2 \\
0.45 \pm 0.04 \\
0.54 \pm 0.05 \\
3.64 \pm 0.36 \\
2.03 \pm 0.16 \\
0.31 \pm 0.02 \\
3.06 \pm 0.25 \\
1.63 \pm 0.11 \\
58 \pm 7 \\
<0.010 \\
0.3 \pm 0.1 \\
18.1 \pm 0.7 \\
2.70 \pm 0.10\end{array}$ & $\begin{array}{c}1.34 \pm 0.06 \\
0.48 \pm 0.07 \\
11.5 \pm 0.5 \\
<81 \\
4.26 \pm 0.28 \\
1.81 \pm 0.12 \\
2.01 \pm 0.11 \\
428 \pm 124 \\
<6 \\
<1.2 \\
269 \pm 11 \\
0.93 \pm 0.05 \\
10.64 \pm 0.56 \\
<245 \\
46 \pm 7 \\
<18.3 \\
2.3 \pm 0.3 \\
<2.8 \\
<2.49 \\
149 \pm 7 \\
<218 \\
110 \pm 30 \\
<89 \\
<1.8 \\
<0.17 \\
<0.29 \\
<13 \\
4.10 \pm 0.24 \\
459 \pm 52 \\
51.4 \pm 3.1 \\
95.7 \pm 4.2 \\
36.5 \pm 2.9 \\
6.4 \pm 0.3 \\
0.51 \pm 0.03 \\
0.81 \pm 0.09 \\
4.55 \pm 0.97 \\
2.50 \pm 0.19 \\
0.39 \pm 0.02 \\
3.53 \pm 0.30 \\
2.52 \pm 0.18 \\
140 \pm 17 \\
<0.012 \\
0.4 \pm 0.1 \\
21.7 \pm 1.1 \\
2.80 \pm 0.10\end{array}$ & $\begin{array}{c}1.25 \pm 0.06 \\
0.38 \pm 0.07 \\
12.0 \pm 0.3 \\
371 \pm 46 \\
5.50 \pm 0.35 \\
1.75 \pm 0.12 \\
2.37 \pm 0.13 \\
<3433 \\
<6 \\
<1.3 \\
256 \pm 10 \\
0.91 \pm 0.05 \\
8.01 \pm 0.44 \\
<196 \\
35 \pm 6 \\
17.5 \pm 3.4 \\
1.9 \pm 0.3 \\
<3.2 \\
<2.71 \\
180 \pm 9 \\
<246 \\
112 \pm 22 \\
<68 \\
<1.9 \\
<0.19 \\
0.51 \pm 0.07 \\
<15 \\
5.90 \pm 0.33 \\
137 \pm 51 \\
28.6 \pm 1.5 \\
53.4 \pm 2.6 \\
25.8 \pm 2.4 \\
4.8 \pm 0.2 \\
0.26 \pm 0.03 \\
0.56 \pm 0.05 \\
3.92 \pm 0.36 \\
1.98 \pm 0.16 \\
0.28 \pm 0.02 \\
3.62 \pm 0.20 \\
2.12 \pm 0.14 \\
65 \pm 8 \\
<0.011 \\
<0.4 \\
21.2 \pm 0.8 \\
2.90 \pm 0.10\end{array}$ & $\begin{array}{c}1.35 \pm 0.06 \\
0.45 \pm 0.09 \\
12.0 \pm 0.3 \\
1244 \pm 97 \\
4.78 \pm 0.31 \\
2.11 \pm 0.13 \\
2.31 \pm 0.12 \\
<3771 \\
<6 \\
<1.2 \\
328 \pm 13 \\
0.92 \pm 0.05 \\
5.31 \pm 0.29 \\
<224 \\
40 \pm 6 \\
<19.3 \\
2.3 \pm 0.4 \\
<2.7 \\
3.22 \pm 0.43 \\
178 \pm 0 \\
<266 \\
130 \pm 24 \\
<80 \\
1.2 \pm 0.3 \\
<0.21 \\
0.48 \pm 0.07 \\
<16 \\
5.08 \pm 0.31 \\
126 \pm 31 \\
28.1 \pm 1.7 \\
56.1 \pm 2.5 \\
26.5 \pm 2.5 \\
5.0 \pm 0.2 \\
0.26 \pm 0.02 \\
0.63 \pm 0.07 \\
3.82 \pm 0.41 \\
2.32 \pm 0.17 \\
0.37 \pm 0.02 \\
3.74 \pm 0.24 \\
1.61 \pm 0.10 \\
27 \pm 3 \\
<0.012 \\
<0.4 \\
22.4 \pm 0.9 \\
2.70 \pm 0.10\end{array}$ & $\begin{array}{c}0.68 \pm 0.03 \\
<0.18 \\
11.4 \pm 0.3 \\
<81 \\
5.86 \pm 0.37 \\
1.39 \pm 0.10 \\
2.30 \pm 0.12 \\
<3180 \\
<6 \\
<1.3 \\
289 \pm 16 \\
0.86 \pm 0.05 \\
6.34 \pm 0.36 \\
<178 \\
33 \pm 5 \\
<14.5 \\
2.5 \pm 0.4 \\
<3.4 \\
1.39 \pm 0.68 \\
222 \pm 11 \\
<191 \\
114 \pm 22 \\
<57 \\
<1.9 \\
<0.16 \\
0.37 \pm 0.07 \\
<13 \\
5.14 \pm 0.30 \\
123 \pm 25 \\
22.4 \pm 1.4 \\
48.1 \pm 2.3 \\
21.5 \pm 1.8 \\
3.8 \pm 0.2 \\
0.21 \pm 0.03 \\
0.51 \pm 0.06 \\
3.69 \pm 0.42 \\
2.25 \pm 0.15 \\
0.30 \pm 0.02 \\
3.50 \pm 0.18 \\
2.14 \pm 0.14 \\
74 \pm 9 \\
<0.007 \\
<0.4 \\
19.5 \pm 0.8 \\
3.10 \pm 0.10\end{array}$ & $\begin{array}{c}1.10 \pm 0.05 \\
<0.21 \\
11.8 \pm 0.3 \\
636 \pm 51 \\
4.95 \pm 0.32 \\
2.04 \pm 0.13 \\
2.34 \pm 0.13 \\
619 \pm 137 \\
<6 \\
<1.2 \\
297 \pm 12 \\
0.87 \pm 0.05 \\
16.67 \pm 0.88 \\
<232 \\
48 \pm 6 \\
<17.0 \\
3.0 \pm 0.4 \\
<2.9 \\
1.67 \pm 0.31 \\
252 \pm 12 \\
<221 \\
140 \pm 27 \\
<75 \\
<1.9 \\
<0.17 \\
0.38 \pm 0.08 \\
<14 \\
5.88 \pm 0.33 \\
154 \pm 18 \\
31.2 \pm 2.0 \\
61.5 \pm 2.7 \\
33.6 \pm 2.8 \\
5.3 \pm 0.2 \\
0.30 \pm 0.04 \\
0.64 \pm 0.07 \\
4.36 \pm 0.41 \\
2.07 \pm 0.17 \\
0.29 \pm 0.02 \\
3.49 \pm 0.25 \\
1.65 \pm 0.11 \\
35 \pm 4 \\
<0.011 \\
<0.4 \\
22.3 \pm 0.9 \\
3.40 \pm 0.10\end{array}$ \\
\hline
\end{tabular}


APPENDIX C. (cont)

Prow Pans Ares (Southern Vertical Section Conhi Site 5 on Fig, 1)

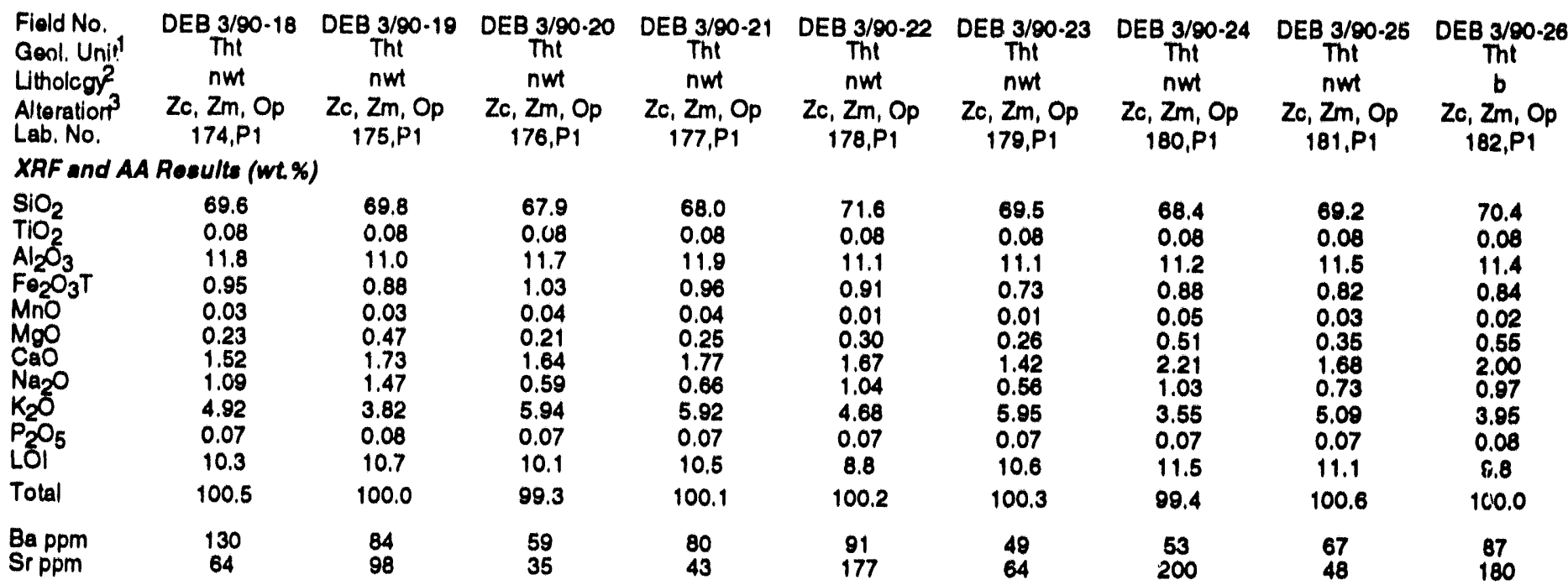

\section{INAA Rosults 4 (all values ppm unlose otherwise noted)}

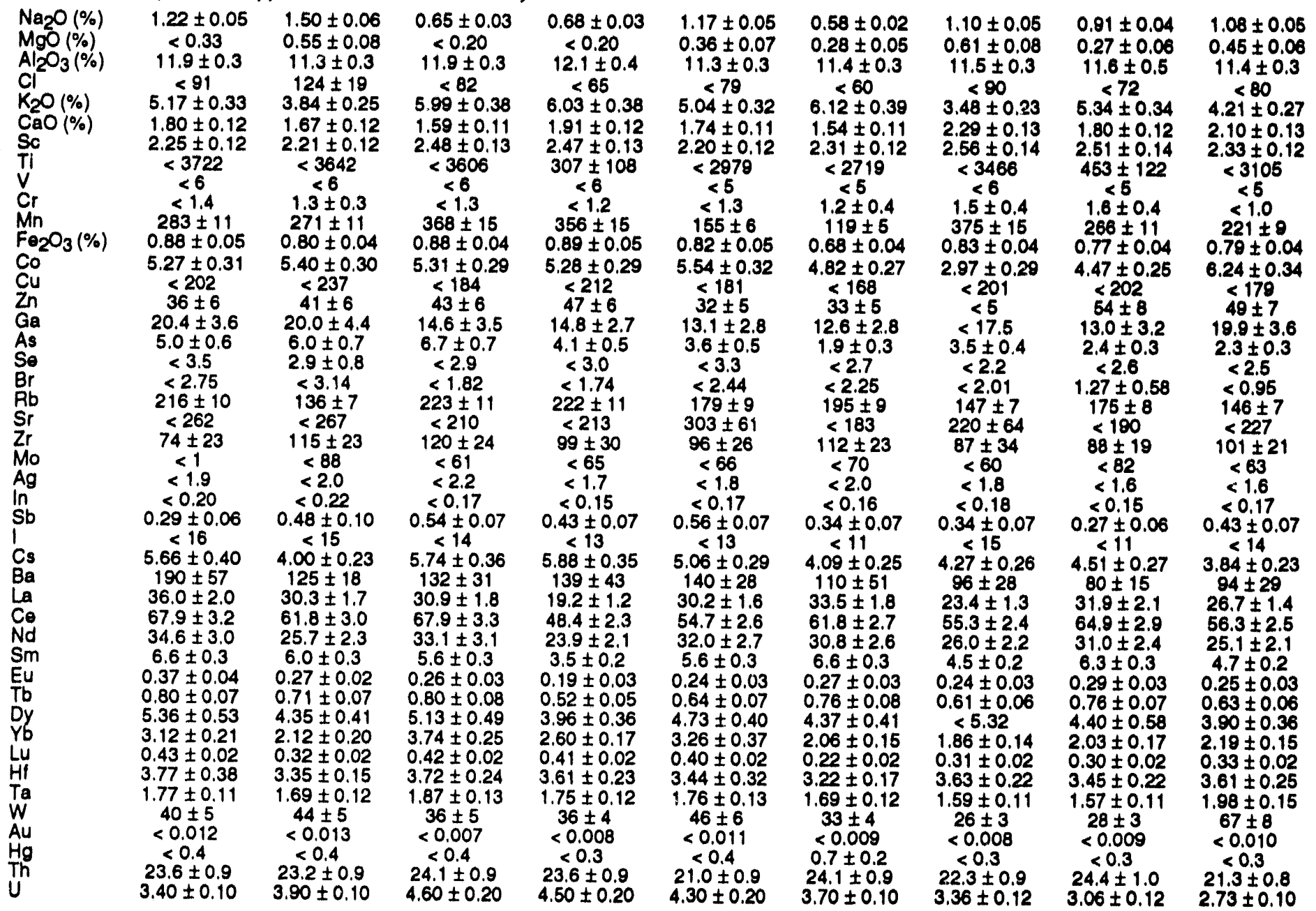


APPENDIX C. (cont)

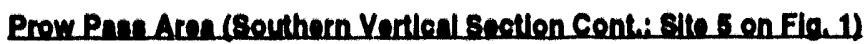

\begin{tabular}{|c|c|c|c|c|c|c|c|c|c|}
\hline $\begin{array}{l}\text { Fleidd No. } \\
\text { Geol. Unil' } \\
\text { Utholog? } \\
\text { Altoration? } \\
\text { Lab. No. }\end{array}$ & $\begin{array}{c}\text { DEB 3/00-27 } \\
\text { Tht } \\
n w t \\
\text { Zc, } \mathrm{Zm}, \mathrm{Op} \\
183, \mathrm{P1}\end{array}$ & $\begin{array}{c}\text { DEB 3/90-28 } \\
\text { Tht } \\
\text { nwt } \\
\text { Zc, Zm, Op } \\
\text { 184,P1 }\end{array}$ & $\begin{array}{c}\text { DEB } 3 / 90-2 \theta \\
\text { Tht } \\
\text { nwt } \\
\text { Zc. } \mathrm{Zm}_{\mathrm{m}} \text { Op } \\
185, \mathrm{P} 1\end{array}$ & $\begin{array}{c}\text { DEB } 3 / 90-30 \\
\text { Tht } \\
b \\
Z c, \mathrm{Zm}_{1} \text { Op } \\
186, \mathrm{Pl}_{1}\end{array}$ & $\begin{array}{c}\text { DEB 3,90-31 } \\
\text { Tht } \\
\text { nwt } \\
\text { Zc, } \mathrm{Zm}, \mathrm{Op}^{\mathrm{m}} \\
\text { 187,P1 }\end{array}$ & $\begin{array}{c}\text { DEB 3/90-32 } \\
\text { Tht } \\
n w t \\
\text { Zc, } \mathrm{Zm}, \text { Op } \\
188, \mathrm{P} 1\end{array}$ & $\begin{array}{c}\text { DEB 3/90-33 } \\
\text { Tpt } \\
n w 1 \\
\text { Zc, } \mathrm{Zm}, \mathrm{Op} \\
189, \mathrm{P} 1\end{array}$ & $\begin{array}{c}\text { DEB } 3 / 90-34 \\
T p t \\
v t \\
\text { GI,Zc, } \mathrm{Zm}, \text { Op } \\
180, \mathrm{Pl}_{1}\end{array}$ & $\begin{array}{c}\text { DEB 3/90-35 } \\
\text { Tpt } \\
v t \\
\text { Gl } \\
191, P_{1}\end{array}$ \\
\hline \multicolumn{10}{|c|}{ XRF and AA Rosulto (wt.x) } \\
\hline $\begin{array}{l}\mathrm{SlO}_{2} \\
\mathrm{TlO}_{3} \\
\mathrm{Al}_{2} \mathrm{O}_{3} \\
\mathrm{FoO}_{3} \mathrm{~T} \\
\mathrm{MnO} \\
\mathrm{MgO} \\
\mathrm{CaO} \\
\mathrm{NagO} \\
\mathrm{K} \mathrm{O}^{\circ} \\
\mathrm{PaO}_{5} \\
\mathrm{LOI}\end{array}$ & $\begin{array}{l}68.9 \\
0.09 \\
11.4 \\
0.89 \\
0.03 \\
0.46 \\
2.30 \\
1.23 \\
3.41 \\
0.07 \\
11.3\end{array}$ & $\begin{array}{l}68.8 \\
0.09 \\
11.3 \\
0.86 \\
0.04 \\
0.51 \\
2.27 \\
1.10 \\
3.55 \\
0.07 \\
11.5\end{array}$ & $\begin{array}{l}69.2 \\
0.08 \\
11.3 \\
0.87 \\
0.03 \\
0.33 \\
2.07 \\
1.06 \\
3.89 \\
0.07 \\
11.3\end{array}$ & $\begin{array}{l}72.1 \\
0.11 \\
10.5 \\
1.03 \\
0.10 \\
0.35 \\
2.00 \\
1.37 \\
3.31 \\
0.07 \\
9.4\end{array}$ & $\begin{array}{l}67.6 \\
0.08 \\
11.4 \\
1.00 \\
0.04 \\
0.38 \\
2.14 \\
0.93 \\
4.30 \\
0.07 \\
12.1\end{array}$ & $\begin{array}{l}67.9 \\
0.09 \\
11.3 \\
0.93 \\
0.05 \\
0.58 \\
3.06 \\
1.13 \\
1.88 \\
0.07 \\
13.4\end{array}$ & $\begin{array}{l}68.8 \\
0.09 \\
11.2 \\
0.82 \\
0.02 \\
0.67 \\
3.07 \\
0.69 \\
2.29 \\
0.07 \\
13.2\end{array}$ & $\begin{array}{l}71.1 \\
0.10 \\
11.4 \\
0.99 \\
0.05 \\
0.46 \\
1.67 \\
1.84 \\
4.21 \\
0.09 \\
8.2\end{array}$ & $\begin{array}{l}74.2 \\
0.10 \\
12.4 \\
1.01 \\
0.06 \\
0.16 \\
0.54 \\
3.44 \\
4.55 \\
0.07 \\
3.7\end{array}$ \\
\hline Total & 100.1 & 100.1 & 100.1 & 100.4 & 100.0 & 100.3 & 100.8 & 100.1 & 100.2 \\
\hline $\begin{array}{l}\text { Ba ppm } \\
\text { Si ppm }\end{array}$ & $\begin{array}{c}63 \\
410\end{array}$ & $\begin{array}{c}58 \\
600\end{array}$ & $\begin{array}{l}48 \\
660\end{array}$ & $\begin{array}{l}178 \\
270\end{array}$ & $\begin{array}{l}43 \\
82\end{array}$ & $\begin{array}{l}36 \\
108\end{array}$ & $\begin{array}{c}28 \\
326\end{array}$ & $\begin{array}{c}18 \\
122\end{array}$ & $\begin{array}{l}46 \\
26\end{array}$ \\
\hline \multicolumn{10}{|c|}{ INA Rosults (all values ppm unlose otherwlee notod) } \\
\hline 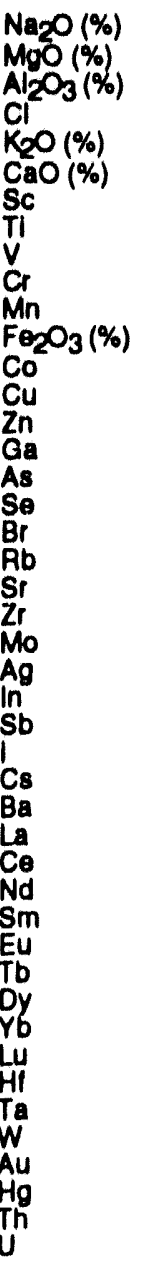 & $\begin{array}{c}1.29 \pm 0.05 \\
0.31 \pm 0.07 \\
11.7 \pm 0.3 \\
105 \pm 22 \\
3.39 \pm 0.22 \\
2.51 \pm 0.15 \\
2.29 \pm 0.12 \\
<3442 \\
<6 \\
<1.3 \\
268 \pm 11 \\
0.80 \pm 0.05 \\
4.69 \pm 0.28 \\
<213 \\
36 \pm 6 \\
8.0 \pm 2.5 \\
2.2 \pm 0.3 \\
<3.1 \\
<2.83 \\
135 \pm 7 \\
363 \pm 74 \\
160 \pm 33 \\
<3 \\
<1.8 \\
<0.20 \\
0.22 \pm 0.07 \\
<14 \\
5.80 \pm 0.33 \\
<60 \pm \\
32.9 \pm 2.2 \\
62.9 \pm 2.8 \\
28.7 \pm 2.6 \\
5.8 \pm 0.3 \\
0.25 \pm 0.02 \\
0.66 \pm 0.07 \\
3.66 \pm 0.36 \\
1.66 \pm 0.15 \\
0.26 \pm 0.02 \\
3.56 \pm 0.24 \\
1.64 \pm 0.11 \\
36 \pm 5 \\
<0.011 \\
<0.4 \\
21.8 \pm 0.8 \\
2.97 \pm 0.11\end{array}$ & $\begin{array}{c}1.19 \pm 0.05 \\
<0.21 \\
11.4 \pm 0.3 \\
<01 \\
3.41 \pm 0.23 \\
2.41 \pm 0.14 \\
2.29 \pm 0.12 \\
<3355 \\
<66 \\
1.3 \pm 0.4 \\
302 \pm 13 \\
0.86 \pm 0.05 \\
4.40 \pm 0.24 \\
<199 \\
40 \pm 5 \\
15.6 \pm 3.5 \\
1.8 \pm 0.3 \\
<2.8 \\
<2.14 \\
161 \pm 8 \\
654 \pm 85 \\
132 \pm 25 \\
<64 \\
<1.9 \\
<0.17 \\
0.25 \pm 0.07 \\
<13 \\
5.80 \pm 0.34 \\
69 \pm 21 \\
32.1 \pm 1.8 \\
60.9 \pm 2.9 \\
34.6 \pm 3.1 \\
5.5 \pm 0.2 \\
0.24 \pm 0.02 \\
0.65 \pm 0.06 \\
4.20 \pm 0.37 \\
2.21 \pm 0.26 \\
0.33 \pm 0.02 \\
3.77 \pm 0.18 \\
1.70 \pm 0.11 \\
40 \pm 5 \\
<0.008 \\
<0.4 \\
21.9 \pm 0.9 \\
2.84 \pm 0.11\end{array}$ & $\begin{array}{c}1.04 \pm 0.04 \\
<0.19 \\
11.6 \pm 0.3 \\
<74 \\
4.26 \pm 0.27 \\
2.11 \pm 0.13 \\
2.35 \pm 0.12 \\
630 \pm 154 \\
<5 \\
<1.0 \\
289 \pm 12 \\
0.82 \pm 0.04 \\
4.31 \pm 0.32 \\
<216 \\
<5 \\
11.8 \pm 3.1 \\
1.4 \pm 0.3 \\
<2.2 \\
<1.88 \\
203 \pm 10 \\
755 \pm 85 \\
123 \pm 33 \\
<2 \\
<1.8 \\
<0.15 \\
0.24 \pm 0.06 \\
<12 \\
5.89 \pm 0.34 \\
94 \pm 20 \\
28.7 \pm 1.9 \\
63.0 \pm 2.9 \\
28.5 \pm 2.4 \\
4.8 \pm 0.2 \\
0.25 \pm 0.02 \\
0.55 \pm 0.05 \\
3.42 \pm 0.32 \\
1.86 \pm 0.16 \\
0.24 \pm 0.02 \\
3.81 \pm 0.23 \\
1.62 \pm 0.11 \\
43 \pm 5 \\
<0.010 \\
<0.3 \\
22.4 \pm 0.9 \\
2.90 \pm 0.11\end{array}$ & $\begin{array}{c}1.42 \pm 0.07 \\
<0.39 \\
10.4 \pm 0.3 \\
189 \pm 23 \\
3.61 \pm 0.23 \\
2.03 \pm 0.13 \\
1.94 \pm 0.11 \\
663 \pm 181 \\
<7 \\
3.0 \pm 0.4 \\
715 \pm 29 \\
0.97 \pm 0.05 \\
7.21 \pm 0.38 \\
<224 \\
61 \pm 8 \\
18.9 \pm 3.7 \\
3.2 \pm 0.4 \\
<2.8 \\
<1.12 \\
154 \pm 8 \\
<351 \\
154 \pm 28 \\
<74 \\
<1.6 \\
<0.23 \\
0.38 \pm 0.08 \\
<21 \\
8.32 \pm 0.47 \\
220 \pm 52 \\
45.4 \pm 2.4 \\
93.4 \pm 4.2 \\
41.3 \pm 3.3 \\
6.4 \pm 0.3 \\
0.36 \pm 0.03 \\
0.83 \pm 0.08 \\
5.25 \pm 0.47 \\
3.89 \pm 0.24 \\
0.56 \pm 0.05 \\
4.18 \pm 0.18 \\
1.85 \pm 0.12 \\
54 \pm 7 \\
<0.012 \\
<0.3 \\
18.6 \pm 0.7 \\
4.38 \pm 0.16\end{array}$ & $\begin{array}{c}0.96 \pm 0.04 \\
0.32 \pm 0.07 \\
11.8 \pm 0.3 \\
<85 \\
4.84 \pm 0.31 \\
2.42 \pm 0.15 \\
2.06 \pm 0.11 \\
<3764 \\
<6 \\
<1.3 \\
338 \pm 14 \\
0.92 \pm 0.05 \\
3.99 \pm 0.25 \\
<182 \\
55 \pm 8 \\
<22.0 \\
2.5 \pm 0.4 \\
<3.2 \\
<2.50 \\
185 \pm 0 \\
<262 \\
154 \pm 26 \\
0 \\
<1.8 \\
<0.19 \\
0.31 \pm 0.06 \\
<16 \\
6.93 \pm 0.39 \\
<74 \\
39.3 \pm 2.2 \\
71.4 \pm 3.1 \\
30.6 \pm 2.5 \\
6.5 \pm 0.3 \\
0.29 \pm 0.02 \\
0.81 \pm 0.08 \\
5.56 \pm 0.56 \\
3.63 \pm 0.41 \\
0.39 \pm 0.02 \\
4.16 \pm 0.31 \\
1.44 \pm 0.11 \\
26 \pm 3 \\
<0.010 \\
<0.4 \\
21.4 \pm 0.8 \\
4.17 \pm 0.15\end{array}$ & $\begin{array}{c}1.21 \pm 0.05 \\
0.49 \pm 0.09 \\
11.6 \pm 0.3 \\
<89 \\
1.81 \pm 0.16 \\
3.01 \pm 0.18 \\
2.03 \pm 0.11 \\
484 \pm 144 \\
<7 \\
<1.3 \\
389 \pm 16 \\
0.84 \pm 0.04 \\
5.19 \pm 0.32 \\
<242 \\
48 \pm 7 \\
<30.7 \\
<2.2 \\
<2.7 \\
<2.78 \\
159 \pm 8 \\
<299 \\
117 \pm 22 \\
<66 \\
<2.1 \\
<0.23 \\
0.20 \pm 0.06 \\
<17 \\
6.91 \pm 0.39 \\
<200 \\
27.1 \pm 1.4 \\
55.0 \pm 2.8 \\
26.0 \pm 2.3 \\
4.1 \pm 0.2 \\
0.24 \pm 0.03 \\
0.47 \pm 0.06 \\
2.76 \pm 0.34 \\
2.11 \pm 0.14 \\
0.28 \pm 0.02 \\
4.31 \pm 0.28 \\
1.36 \pm 0.11 \\
16 \pm 2 \\
<0.010 \\
<0.4 \\
21.9 \pm 0.9 \\
2.22 \pm 0.09\end{array}$ & $\begin{array}{c}0.71 \pm 0.03 \\
0.59 \pm 0.05 \\
11.6 \pm 0.3 \\
<76 \\
2.57 \pm 0.19 \\
3.10 \pm 0.17 \\
2.04 \pm 0.11 \\
<2871 \\
<5 \\
<1.0 \\
176 \pm 7 \\
0.86 \pm 0.04 \\
3.86 \pm 0.31 \\
<168 \\
<5 \\
22.8 \pm 5.0 \\
2.2 \pm 0.4 \\
<2.3 \\
<2.50 \\
121 \pm 6 \\
455 \pm 66 \\
149 \pm 32 \\
<69 \\
<1.7 \\
<0.15 \\
0.23 \pm 0.06 \\
<11 \\
4.91 \pm 0.28 \\
<170 \\
42.0 \pm 2.3 \\
82.8 \pm 3.8 \\
41.4 \pm 3.2 \\
7.4 \pm 0.3 \\
0.32 \pm 0.03 \\
0.89 \pm 0.09 \\
4.75 \pm 0.58 \\
1.88 \pm 0.14 \\
0.26 \pm 0.02 \\
4.11 \pm 0.21 \\
1.36 \pm 0.10 \\
13 \pm 2 \\
<0.009 \\
<0.3 \\
24.0 \pm 1.0 \\
3.82 \pm 0.14\end{array}$ & $\begin{array}{c}1.90 \pm 0.08 \\
0.36 \pm 0.06 \\
12.2 \pm 0.3 \\
157 \pm 22 \\
4.10 \pm 0.28 \\
1.73 \pm 0.11 \\
2.28 \pm 0.12 \\
536 \pm 139 \\
<5 \\
<0.8 \\
426 \pm 18 \\
0.95 \pm 0.05 \\
5.55 \pm 0.29 \\
<233 \\
55 \pm 7 \\
<30.9 \\
2.5 \pm 0.4 \\
<2.3 \\
<1.39 \\
181 \pm 9 \\
<214 \\
118 \pm 20 \\
<76 \\
<1.4 \\
<0.17 \\
0.24 \pm 0.06 \\
<13 \\
7.26 \pm 0.41 \\
93 \pm 13 \\
27.1 \pm 1.6 \\
63.1 \pm 2.8 \\
28.4 \pm 2.3 \\
4.5 \pm 0.2 \\
0.25 \pm 0.04 \\
0.41 \pm 0.11 \\
3.72 \pm 1.06 \\
2.22 \pm 0.16 \\
0.32 \pm 0.02 \\
4.39 \pm 0.29 \\
1.81 \pm 0.13 \\
50 \pm 6 \\
<0.008 \\
<0.3 \\
22.2 \pm 1.3 \\
3.71 \pm 0.13\end{array}$ & $\begin{array}{c}3.48 \pm 0.15 \\
<0.37 \\
12.3 \pm 0.3 \\
505 \pm 43 \\
4.89 \pm 0.33 \\
0.59 \pm 0.06 \\
2.28 \pm 0.12 \\
<4033 \\
<6 \\
<1.0 \\
504 \pm 21 \\
0.94 \pm 0.05 \\
6.38 \pm 0.34 \\
<245 \\
47 \pm 7 \\
<33.7 \\
4.3 \pm 0.6 \\
<2.6 \\
<1.27 \\
179 \pm 8 \\
<290 \\
113 \pm 20 \\
7 \pm 4 \\
<1.5 \\
<0.23 \\
<0.25 \\
<18 \\
6.79 \pm 0.39 \\
78 \pm 32 \\
33.5 \pm 2.1 \\
71.0 \pm 3.1 \\
34.0 \pm 2.8 \\
6.1 \pm 0.3 \\
0.26 \pm 0.03 \\
0.71 \pm 0.07 \\
4.50 \pm 0.41 \\
2.84 \pm 0.20 \\
0.39 \pm 0.02 \\
4.52 \pm 0.26 \\
2.26 \pm 0.14 \\
73 \pm 9 \\
<0.011 \\
<0.3 \\
23.3 \pm 0.9 \\
4.71 \pm 0.16\end{array}$ \\
\hline
\end{tabular}


APPENDIX C. (cont)

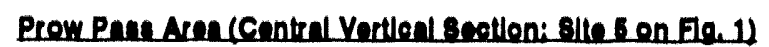

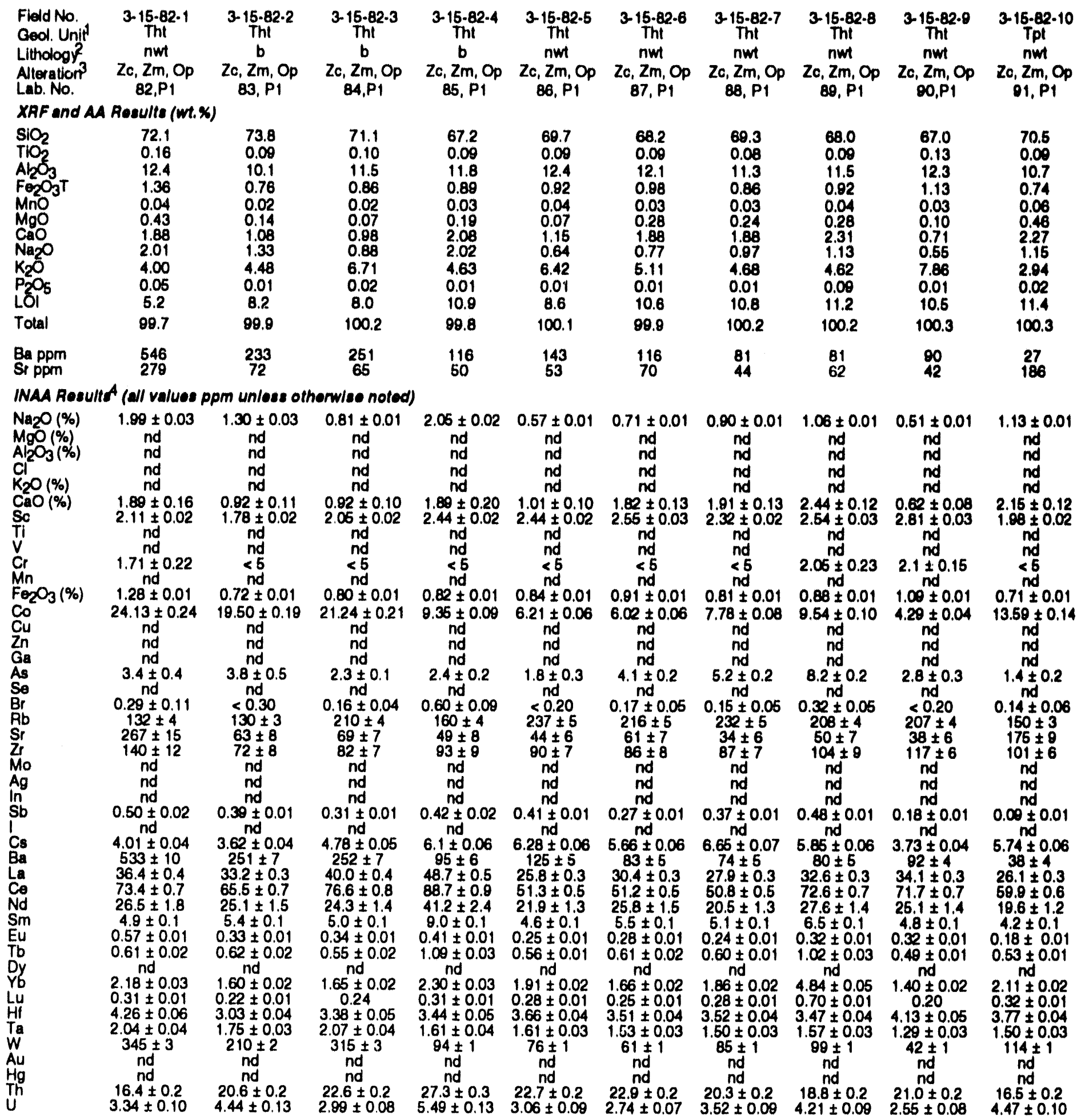


APPENDIX C. (cont)

Brom Pan Aren (Northern Yertleal section; Site 5 on Fio.1)

\begin{tabular}{|c|c|c|c|c|c|c|c|}
\hline $\begin{array}{l}\text { Field No. } \\
\text { Geol. Unip } \\
\text { Uthology } \\
\text { Altoriton } \\
\text { Lab. No. }\end{array}$ & $\begin{array}{c}3 \cdot 15-82 \cdot 11 \\
T p t \\
p m t \\
Q 1, Z c, Z m, O p \\
92, P 1\end{array}$ & $\begin{array}{c}\text { 82FB-1 } \\
\text { Tht } \\
n w t \\
Z m \\
110, P_{1}\end{array}$ & $\begin{array}{c}\text { 82FB-2 } \\
T h t \\
n w t \\
\mathrm{Zc}_{\mathrm{n}} \mathrm{Zm}, \mathrm{Op} \\
111, \mathrm{Pl}_{1}\end{array}$ & $\begin{array}{c}\text { B2FB-3A } \\
T h t \\
n w t \\
Z c_{1}, Z m, O p \\
112, P_{1}\end{array}$ & $\begin{array}{c}\text { 82FB-3B } \\
T h t \\
n w t \\
Z c, Z_{1}, O p \\
113, P 1\end{array}$ & $\begin{array}{c}\text { 82F日.4 } \\
\text { Tht } \\
n w t \\
Z c_{1}, \mathrm{Zm}_{1} \mathrm{Op}_{\mathrm{p}} \\
114, \mathrm{P}_{1}\end{array}$ & $\begin{array}{c}\text { O2FB.5 } \\
T h t \\
n w t \\
Z c, Z m, O p \\
115, P_{1}\end{array}$ \\
\hline \multicolumn{8}{|c|}{$X R F$ and $A A$ Results (wh $x$ ) } \\
\hline $\begin{array}{l}\mathrm{SOO}_{2} \\
\mathrm{THO}_{2} \\
\mathrm{Al}_{3} \mathrm{O}_{3} \\
\mathrm{FemO}_{3} \mathrm{~T} \\
\mathrm{MnO} \\
\mathrm{MaO} \\
\mathrm{CaO} \\
\mathrm{NaOO} \\
\mathrm{KaO}_{2} \\
\mathrm{PaO}_{5} \\
\mathrm{LO}_{6}\end{array}$ & $\begin{array}{l}68.8 \\
0.10 \\
12.1 \\
0.06 \\
0.06 \\
0.51 \\
1.91 \\
1.74 \\
3.43 \\
0.01 \\
10.6\end{array}$ & $\begin{array}{l}68.7 \\
0.15 \\
12.8 \\
1.28 \\
0.04 \\
0.42 \\
2.34 \\
1.96 \\
1.40 \\
0.06 \\
7.7\end{array}$ & $\begin{array}{l}70.7 \\
0.15 \\
11.8 \\
1.28 \\
0.03 \\
0.52 \\
1.76 \\
1.60 \\
4.68 \\
0.03 \\
7.3\end{array}$ & $\begin{array}{l}69.6 \\
0.15 \\
12.4 \\
1.23 \\
0.06 \\
0.34 \\
1.62 \\
1.57 \\
5.12 \\
0.02 \\
7.9\end{array}$ & $\begin{array}{l}68.6 \\
0.13 \\
10.8 \\
1.10 \\
0.03 \\
1.05 \\
3.11 \\
2.20 \\
4.95 \\
0.04 \\
9.9\end{array}$ & $\begin{array}{l}68.1 \\
0.17 \\
11.5 \\
1.00 \\
0.07 \\
1.20 \\
2.54 \\
1.60 \\
4.50 \\
0.02 \\
9.3\end{array}$ & $\begin{array}{l}68.5 \\
0.18 \\
12.0 \\
1.06 \\
0.07 \\
0.20 \\
1.00 \\
1.56 \\
6.11 \\
0.03 \\
0.2\end{array}$ \\
\hline rotal & 100,3 & 99.8 & 90.8 & 99.9 & 99.9 & 100.0 & 99.9 \\
\hline $\begin{array}{l}\text { 3a ppm } \\
\text { Pr ppm }\end{array}$ & $\begin{array}{r}45 \\
220\end{array}$ & $\begin{array}{l}573 \\
106\end{array}$ & $\begin{array}{l}573 \\
254\end{array}$ & $\begin{array}{l}636 \\
109\end{array}$ & $\begin{array}{l}412 \\
127\end{array}$ & $\begin{array}{l}143 \\
237\end{array}$ & $\begin{array}{l}161 \\
110\end{array}$ \\
\hline \multicolumn{8}{|c|}{ INAA Recultse (all valuee ppm unloes othorwise noted) } \\
\hline 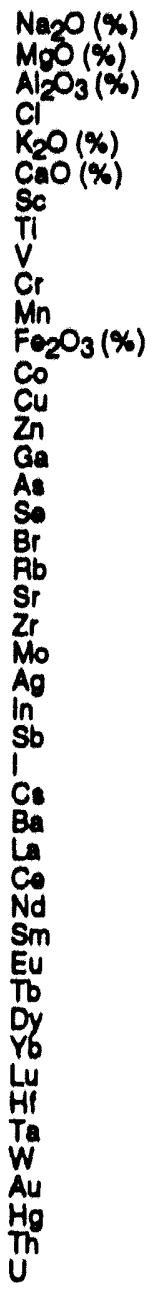 & $\begin{array}{c}1.68 \pm 0.02 \\
\text { nd } \\
\text { nd } \\
\text { nd } \\
\text { nd } \\
1.94 \pm 0.17 \\
2.25 \pm 0.02 \\
\text { nd } \\
\text { nd } \\
2.35 \pm 0.21 \\
\text { nd } \\
0.84 \pm 0.01 \\
4.16 \pm 0.04 \\
\text { nd } \\
\text { nd } \\
\text { nd } \\
1.7 \pm 0.2 \\
\text { nd } \\
0.65 \pm 0.11 \\
158 \pm 4 \\
242 \pm 13 \\
114 \pm 8 \\
\text { nd } \\
\text { nd } \\
\text { nd } \\
0.14 \pm 0.01 \\
\text { nd } \\
4.99 \pm 0.05 \\
48 \pm 5 \\
45.8 \pm 0.5 \\
93.0 \pm 0.9 \\
30.9 \pm 1.8 \\
5.8 \pm 0.1 \\
0.23 \pm 0.01 \\
0.83 \pm 0.02 \\
\text { nd } \\
2.14 \pm 0.02 \\
0.30 \pm 0.01 \\
4.13 \pm 0.05 \\
1.57 \pm 0.04 \\
28 \pm 1 \\
\text { nd } \\
\text { nd } \\
\text { nd } \\
22.4 \pm 0.2 \\
3.45 \pm 0.09\end{array}$ & $\begin{array}{c}1.88 \pm 0.02 \\
\text { nd } \\
\text { nd } \\
\text { nd } \\
\text { nd } \\
2.4 \pm 0.21 \\
2.43 \pm \pm 0.02 \\
2.32 \pm 0 \\
\text { nd } \\
\text { nd } \\
\text { nd } \\
\text { nd } \\
1.21 \pm 0.01 \\
12.44 \pm 0.12 \\
\text { nd } \\
\text { nd } \\
\text { nd } \\
9.5 \pm 0.7 \\
\text { nd } \\
0.33 \pm 0.13 \\
291 \pm 8 \\
134 \pm 21 \\
119 \pm 15 \\
\text { nd } \\
\text { nd } \\
\text { nd } \\
1.85 \pm 0.06 \\
\text { nd } \\
355 \pm 3.55 \\
618 \pm 18 \\
50.4 \pm 0.5 \\
94.3 \pm 0.9 \\
34.0 \pm 3.1 \\
5.8 \pm 0.1 \\
0.54 \pm 0.02 \\
0.66 \pm 0.03 \\
\text { nd } \\
2.29 \pm 0.04 \\
0.36 \pm 0.01 \\
4.14 \pm 0.08 \\
1.57 \pm 0.04 \\
148 \pm 2 \\
\text { nd } \\
\text { nd } \\
22.1 \pm 0.2 \\
3.52 \pm 0.15\end{array}$ & $\begin{array}{c}1.61 \pm 0.02 \\
\text { nd } \\
\text { nd } \\
\text { nd } \\
\text { nd } \\
1.75 \pm 0.19 \\
2.26 \pm 0.02 \\
\text { nd } \\
\text { nd } \\
10.8 \pm 0.55 \\
\text { nd } \\
1.21 \pm 0.01 \\
12.00 \pm 0.13 \\
\text { nd } \\
\text { nd } \\
\text { nd } \\
16.8 \pm 0.7 \\
\text { nd } \\
2.70 \pm 0.31 \\
134 \pm 4 \\
275 \pm 19 \\
131 \pm 13 \\
\text { nd } \\
\text { nd } \\
\text { nd } \\
1.97 \pm 0.05 \\
\text { nd } \\
100 \pm 1 \\
529 \pm 13 \\
48.3 \pm 0.5 \\
90.9 \pm 0.9 \\
31.6 \pm 2.5 \\
5.4 \pm 0.1 \\
0.51 \pm 0.01 \\
1.57 \pm 0.02 \\
\text { nd } \\
2.06 \pm 0.03 \\
0.30 \pm 0.01 \\
4.06 \pm 0.06 \\
1.55 \pm 0.04 \\
174 \pm 2 \\
\text { nd } \\
\text { nd } \\
20.9 \pm 0.2 \\
2.96 \pm 0.12\end{array}$ & $\begin{array}{c}1.56 \pm 0.02 \\
\text { nd } \\
\text { nd } \\
\text { nd } \\
\text { nd } \\
\text { nd } \\
1.68 \pm 0.18 \\
2.41 \pm 0.02 \\
\text { nd } \\
\text { nd } \\
19.4 \pm 0.35 \\
\text { nd } \\
1.18 \pm 0.01 \\
11.35 \pm 0.11 \\
\text { nd } \\
\text { nd } \\
\text { nd } \\
7.2 \pm 0.4 \\
\text { nd } \\
<0.30 \\
184 \pm 4 \\
205 \pm 12 \\
133 \pm 0 \\
\text { nd } \\
\text { nd } \\
\text { nd } \\
1.67 \pm 0.03 \\
\text { nd } \\
13.98 \pm 0.14 \\
605 \pm 11 \\
50.3 \pm 0.5 \\
97.9 \pm 1.0 \\
29.5 \pm 1.7 \\
5.6 \pm 0.1 \\
0.61 \pm 0.01 \\
0.61 \pm 0.02 \\
\text { nd } \\
2.36 \pm 0.03 \\
0.35 \pm 0.01 \\
4.22 \pm 0.05 \\
1.53 \pm 0.03 \\
149 \pm 2 \\
\text { nd } \\
\text { nd } \\
23.1 \pm 0.2 \\
4.25 \pm 0.13\end{array}$ & $\begin{array}{c}2.11 \pm 0.02 \\
\text { nd } \\
\text { nd } \\
\text { nd } \\
\text { nd } \\
3.20 \pm 0.21 \\
2.15 \pm 0.02 \\
\text { nd } \\
\text { nd } \\
2.82 \pm 0.11 \\
\text { nd } \\
1.06 \pm 0.01 \\
19.82 \pm 0.20 \\
\text { nd } \\
\text { nd } \\
\text { nd } \\
9.7 \pm 0.3 \\
\text { nd } \\
3.08 \pm 0.25 \\
125 \pm 2 \\
135 \pm 8 \\
121 \pm 6 \\
\text { nd } \\
\text { nd } \\
\text { nd } \\
0.55 \pm 0.01 \\
\text { nd } \\
8.76 \pm 0.09 \\
384 \pm 7 \\
44.1 \pm 0.4 \\
84.3 \pm 0.8 \\
28.4 \pm 1.5 \\
5.1 \pm 0.1 \\
0.45 \pm 0.01 \\
0.57 \pm 0.01 \\
\text { nd } \\
2.04 \pm 0.02 \\
0.30 \pm 0.01 \\
3.89 \pm 0.04 \\
1.50 \pm 0.02 \\
180 \pm 2 \\
n d \\
\text { nd } \\
\text { nd } \\
19.7 \pm 0.2 \\
4.37 \pm 0.12\end{array}$ & $\begin{array}{c}1.55 \pm 0.02 \\
\text { nd } \\
\text { nd } \\
\text { nd } \\
\text { nd } \\
\text { nd } \\
2.41 \pm 0.16 \\
1.94 \pm 0.02 \\
\text { nd } \\
\text { nd } \\
\text { id } \\
\text { nd } \\
0.99 \pm 0.01 \\
5.18 \pm 0.05 \\
\text { nd } \\
\text { nd } \\
\text { nd } \\
4.1 \pm 0.2 \\
\text { nd } \\
0.42 \pm 0.06 \\
143 \pm 3 \\
220 \pm 11 \\
193 \pm 8 \\
\text { nd } \\
\text { nd } \\
\text { nd } \\
1.16 \pm 0.02 \\
\text { nd } \\
5.33 \pm 0.05 \\
157 \pm 6 \\
34.0 \pm 0.3 \\
69.5 \pm 0.7 \\
25.4 \pm 1.5 \\
6.0 \pm 0.1 \\
0.44 \pm 0.01 \\
0.82 \pm 0.02 \\
\text { nd } \\
2.96 \pm 0.03 \\
0.43 \pm 0.01 \\
6.36 \pm 0.07 \\
1.57 \pm 0.03 \\
50 \pm 1 \\
\text { nd } \\
\text { nd } \\
20.9 \pm 0.2 \\
4.12 \pm 0.10\end{array}$ & $\begin{array}{c}1.49 \pm 0.04 \\
\text { nd } \\
\text { nd } \\
\text { nd } \\
\text { nd } \\
1.04 \pm 0.14 \\
2.13 \pm 0.02 \\
\text { nd } \\
\text { nd } \\
\text { nd } \\
\text { nd } \\
0.94 \pm 0.01 \\
9.59 \pm 0.10 \\
\text { nd } \\
\text { nd } \\
\text { nd } \\
3.9 \pm 0.4 \\
\text { nd } \\
<0.50 \\
232 \pm 5 \\
121 \pm 8 \\
200 \pm 7 \\
\text { nd } \\
\text { nd } \\
\text { nd } \\
0.39 \pm 0.01 \\
\text { nd } \\
4.76 \pm 0.05 \\
149 \pm 5 \\
63.2 \pm 0.6 \\
123.3 \pm 1.2 \\
45.0 \pm 2.1 \\
10.5 \pm 0.1 \\
0.63 \pm 0.0 \\
1.44 \pm 0.02 \\
\text { nd } \\
3.21 \pm 0.03 \\
0.44 \pm 0.01 \\
6.71 \pm 0.07 \\
1.83 \pm 0.03 \\
98 \pm 1 \\
\text { nd } \\
\text { nd } \\
21.8 \pm 0.2 \\
4.33 \pm 0.12\end{array}$ \\
\hline
\end{tabular}


APPENDIX C. (cont)

Prow Pan Aron(N-S Lateral Sactioni Site 5 on Fin 1$)$

Fiold No. CRPP.1.SNL CRPP.2.SNL CRPP.3.SNL CRPP.4.SNL CRPP.6.SNL

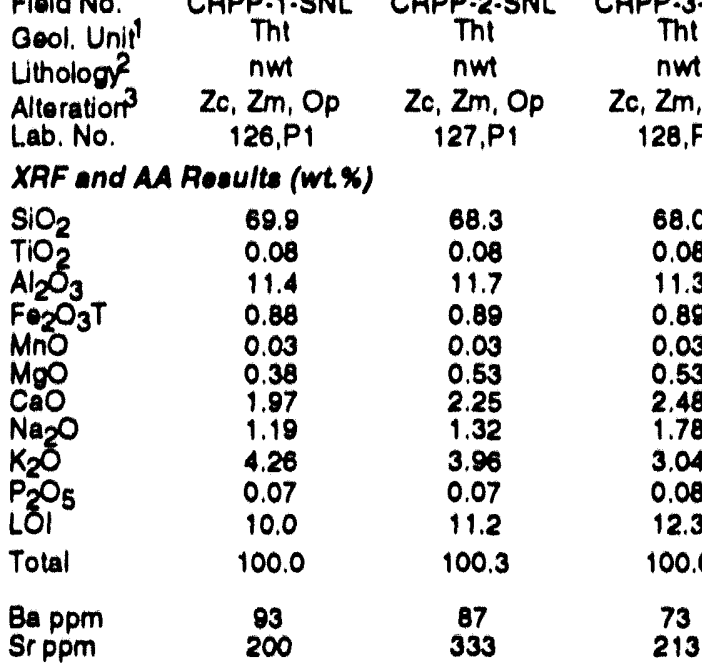

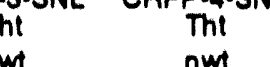

$\mathrm{Zm}, \mathrm{Op}$

28, $\mathrm{P1}$

Zc, $Z m, O p$

$\begin{array}{cc}68.0 & 68.7 \\ 0.08 & 0.08 \\ 11.3 & 11.3 \\ 0.89 & 0.91 \\ 0.03 & 0.02 \\ 0.53 & 0.48 \\ 2.48 & 2.66 \\ 1.78 & 0.92 \\ 3.04 & 3.26 \\ 0.08 & 0.07 \\ 12.3 & 12.3 \\ 100.6 & 100.7\end{array}$

73
213

INAA Resulto (all values ppm unless othonwise noted)

\begin{tabular}{|c|c|c|c|}
\hline $\operatorname{Vax}$ & $\begin{array}{c}1.22 \pm 0.05 \\
<0.20 \\
11.8 \pm 0.3 \\
<01 \\
4.05 \pm 0.26 \\
2.07 \pm 0.13 \\
2.32 \pm 0.12 \\
684 \pm 162 \\
<6 \\
1.8 \pm 0.4 \\
227 \pm 9 \\
0.83 \pm 0.04 \\
6.23 \pm 0.34 \\
<200 \\
43 \pm 6 \\
14.2 \pm 2.8 \\
6.0 \pm 0.7 \\
<2.8 \\
<2.22 \\
168 \pm 8 \\
<196 \\
103 \pm 21 \\
<68 \\
<1.6 \\
<0.18 \\
0.32 \pm 0.08 \\
<13 \\
4.67 \pm 0.30 \\
109 \pm 17 \\
25.8 \pm 1.5 \\
50.9 \pm 2.2 \\
22.9 \pm 2.0 \\
4.4 \pm 0.2 \\
0.24 \pm 0.03 \\
0.58 \pm 0.06 \\
4.03 \pm 0.37 \\
1.95 \pm 0.17 \\
0.30 \pm 0.02 \\
3.43 \pm 0.26 \\
2.07 \pm 0.16 \\
73 \pm 9 \\
<0.009 \\
<0.3 \\
22.5 \pm 0.9 \\
2.00 \pm 0.10\end{array}$ & $\begin{array}{c}1.31 \pm 0.06 \\
c .39 \pm 0.07 \\
12.1 \pm 0.3 \\
<83 \\
4.09 \pm 0.27 \\
2.49 \pm 0.15 \\
2.42 \pm 0.13 \\
<2980 \\
<5 \\
1.8 \pm 0.4 \\
235 \pm 11 \\
0.83 \pm 0.04 \\
5.84 \pm 0.32 \\
<242 \\
50 \pm 7 \\
9.7 \pm 2.4 \\
2.6 \pm 0.4 \\
<2.8 \\
<1.15 \\
156 \pm 8 \\
406 \pm 78 \\
126 \pm 25 \\
<1 \\
<1.8 \\
<0.17 \\
<0.26 \\
<13 \\
4.09 \pm 0.24 \\
142 \pm 35 \\
26.4 \pm 1.6 \\
59.4 \pm 2.8 \\
25.3 \pm 2.1 \\
5.2 \pm 0.2 \\
0.25 \pm 0.02 \\
0.68 \pm 0.06 \\
4.94 \pm 0.43 \\
2.42 \pm 0.22 \\
0.45 \pm 0.02 \\
3.58 \pm 0.25 \\
1.89 \pm 0.13 \\
50 \pm 6 \\
<0.012 \\
<0.3 \\
23.8 \pm 0.9 \\
4.60 \pm 0.20\end{array}$ & $\begin{array}{c}1.88 \pm 0.09 \\
0.61 \pm 0.10 \\
11.9 \pm 0.3 \\
<112 \\
3.21 \pm 0.21 \\
<0.82 \pm \\
2.23 \pm 0.12 \\
<3812 \\
<6 \\
2.1 \pm 0.4 \\
222 \pm 9 \\
0.79 \pm 0.04 \\
3.70 \pm 0.25 \\
<232 \\
33 \pm 6 \\
<21.4 \\
5.1 \pm 0.6 \\
<3.4 \\
<0.95 \\
157 \pm 8 \\
<276 \\
114 \pm 29 \\
<86 \\
<1.9 \\
<0.23 \\
<0.35 \\
<17 \\
5.48 \pm 0.32 \\
<235 \\
34.3 \pm 1.8 \\
65.7 \pm 2.9 \\
28.8 \pm 2.4 \\
6.7 \pm 0.3 \\
0.35 \pm 0.03 \\
0.75 \pm 0.07 \\
5.10 \pm 0.67 \\
2.72 \pm 0.20 \\
0.36 \pm 0.02 \\
3.30 \pm 0.25 \\
1.63 \pm 0.10 \\
28 \pm 4 \\
<0.014 \\
<0.4 \\
20.4 \pm 0.8 \\
3.60 \pm 0.10\end{array}$ \\
\hline
\end{tabular}

$129, P 1$

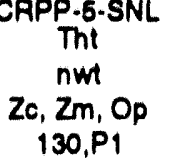

CAPP-6.SNL

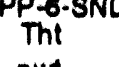

Zc, Zm, Op

$131, P_{1}$

72.6
0.07
9.4
0.87
0.06
0.25
1.73
0.55
4.37
0.07
10.3
100.3

62
129

67

$0.86 \pm 0.04$

$0.51 \pm 0.08$

$11.5 \pm 0.3$

$63 \pm 13$

$3.15 \pm 0.20$

$2.70 \pm 0.16$

$2.32 \pm 0.12$

$311 \pm 110$

$<6$

$2.0 \pm 0.5$

$221 \pm 0$

$0.83 \pm 0.04$

$4.51 \pm 0.25$

$<205$

$38 \pm 6$

$2.6 \pm 0.4$

$<2.7$

$<1.26$

$185 \pm 8$

$<238$

$<86$
$<77$

$<2.1$

$<0.19$

$<0.27$

$<14$

$6.41 \pm 0.37$

$84 \pm 25$

$26.8 \pm 1.5$

$60.3 \pm 3.0$

$27.1 \pm 2.4$

$5.5 \pm 0.3$

$0.27 \pm 0.03$

$0.61 \pm 0.07$

$4.22 \pm 0.40$

$1.87 \pm 0.18$

$0.24 \pm 0.02$

$3.62 \pm 0.21$

$1.75 \pm 0.13$

$38 \pm 5$

$<0.011$

$<0.4$

$3.20 \pm 0.10$
$0.59 \pm 0.02$

$0.33 \pm 0.06$

$0.7 \pm 0.3$

$<76$

$4.14 \pm 0.27$

$1.63 \pm 0.11$

$1.92 \pm 0.10$

$<3673$

$<6$

$2.5 \pm 0.4$

$504 \pm 20$

$0.79 \pm 0.04$

$4.03 \pm 0.25$

$<173$

$39 \pm 6$
$7.5 \pm 2$

$6.7 \pm 0.7$

$<3.2$

$<1.60$

$219 \pm 11$

$<217$

$117 \pm 24$

$<54$

$<1.7$

$<0.16$
$0.27+0.08$

$0.27 \pm 0.06$
$<15$

$6.12 \pm 0.34$

$130 \pm 54$

$25.6 \pm 1.4$

$56.4 \pm 2.5$

$26.4 \pm 2.4$

$4.6 \pm 0.2$

$0.28 \pm 0.04$

$0.74 \pm 0.07$

$4.79 \pm 0.40$

$3.24 \pm 0.19$

$0.43 \pm 0.02$

$2.90 \pm 0.34$

$1.45 \pm 0.11$

$43 \pm 5$

$<0.007$

$<0.4$

$17.8 \pm 0.7$

$5.30 \pm 0.20$

69.4
0.06
11.7
0.93
0.03
0.30
2.10
1.53
4.52
0.08
9.9
100.5

87

$255 \pm 11$

$0.87 \pm 0.05$

$4.51 \pm 0.25$

$<244$

$49 \pm 6$

$23.8 \pm 4.2$

$3.4 \pm 0.5$

$<2.9$

$1.98 \pm 0.76$

$218 \pm 10$

$<210$

$101 \pm 22$

$<3$

$<1.7$

$<0.17$

$0.50 \pm 0.08$

$<13$

$5.86 \pm 0.35$

$97 \pm 16$

$35.4 \pm 2.2$

$79.9 \pm 3.7$

$42.5 \pm 3.4$

$7.7 \pm 0.4$

$0.30 \pm 0.03$

$0.89 \pm 0.09$

$6.09 \pm 0.54$

$2.85 \pm 0.22$

$0.35 \pm 0.02$

$3.85 \pm 0.20$

$1.71 \pm 0.12$

$31 \pm 4$

$<0.012$

$25.2 \pm 1.0$

$4.10 \pm 0.20$
CRPP.7.SNL

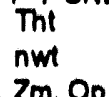

132, P1

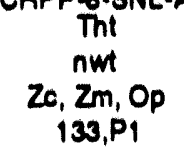

68.6
0.08
11.7
0.02
0.04
0.20
1.21
0.57
6.77
0.07
10.3
100.4

69.8

0.08

10.8

0.95

0.03

0.37

1.78

1.21
4.48

0.07

10.7

100.4

104

88

$1.51 \pm 0.06$
$<0.20$
$12.0 \pm 0.3$
$463 \pm 62$
$4.41 \pm 0.28$
$2.12 \pm 0.13$
$2.45 \pm 0.13$
$<2932$
$<6$
$2.1 \pm 0.5$

$0.62 \pm 0.03$
$<0.24$
$12.1 \pm 0.4$
$<70$
$6.00 \pm 0.44$
$1.31 \pm 0.10$
$2.37 \pm 0.13$
$<3610$
$<6$

$358 \pm 14$
$0.83 \pm 0.04$

$3.40 \pm 0.23$

$<192$

$37 \pm 6$

$14.9 \pm 2.7$

$5.7 \pm 0.6$

$<3.6$

$<2.24$

$251 \pm 12$

$<251$

$79 \pm 27$

$<69$

$<1.9$

$<0.19$

$0.35 \pm 0.06$

$4.90 \pm 0.29$

$106 \pm 43$

$27.4 \pm 1.4$

$55.8 \pm 2.5$

$26.6 \pm 2.2$

$5.3 \pm 0.2$

$0.24 \pm 0.02$

$0.66 \pm 0.06$

$4.98 \pm 0.46$

$2.91 \pm 0.18$

$0.31 \pm 0.02$

$3.40 \pm 0.22$

$1.65 \pm 0.12$

$31 \pm 4$

$<0.000$

$<0.4$

$20.7 \pm 0.8$

$3.00 \pm 0.10$
$1.24 \pm 0.06$

$<1.08$

$10.6 \pm 0.6$

$358 \pm 33$

$4.52 \pm 0.29$

$1.34 \pm 0.10$

$2.17 \pm 0.11$

$<3174$

$4.1 \pm 0$.

$213 \pm 10$

$0.80 \pm 0.04$

$4.36 \pm 0.24$

$<203$

$42 \pm 7$

$11.0 \pm 3.0$

$5.6 \pm 0.7$

$<2.6$

$<0.96$

$<200$

$87 \pm 21$

$<67$

$<2.0$

$<0.18$

$0.41 \pm 0.08$ $<13$

$4.73 \pm 0.30$

$139 \pm 58$

$26.1 \pm 1.6$

$65.0 \pm 2.7$

$24.1 \pm 2.2$

$4.5 \pm 0.2$

$0.22 \pm 0.02$

$0.66 \pm 0.06$

$3.70 \pm 0.33$

$2.28 \pm 0.18$

$0.30 \pm 0.02$

$3.34 \pm 0.27$

$1.64 \pm 0.10$

$40 \pm 5$

$<0.009$

$<0.4$

$19.1 \pm 0.7$

$3.70 \pm 0.10$ 
APPENDIX C. (cont)

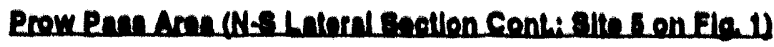

\begin{tabular}{|c|c|c|c|c|c|c|c|c|}
\hline $\begin{array}{l}\text { Fild No. } \\
\text { Cecol. Unif } \\
\text { Utholog? } \\
\text { Alteraltor } \\
\text { Lab. No. }\end{array}$ & $\begin{array}{c}\text { CAPP.Q-SNL-A } \\
\text { Tht } \\
n w 1 \\
2 c, \mathrm{Zm}_{1} \mathrm{Op}_{\mathrm{p}} \\
133, \mathrm{Pz}\end{array}$ & $\begin{array}{c}\text { CRPP.0.SNL } \\
\text { Tht } \\
n w \\
\text { Zc. } 2 \mathrm{~m}, \mathrm{Op} \\
134, \mathrm{P1}\end{array}$ & $\begin{array}{c}\text { CAPP.10-SNL } \\
\text { Tht } \\
\text { nwt } \\
\text { Zc. } \mathrm{Zm}_{1}, \mathrm{Op}_{\mathrm{p}} \\
135, \mathrm{P}_{1}\end{array}$ & $\begin{array}{c}\text { CAPP.11-SNL } \\
\text { Tht } \\
\text { nWt } \\
20, \mathrm{Zm}_{1} \text { Op } \\
136, \mathrm{Pl}_{1}\end{array}$ & $\begin{array}{c}\text { CAPP.12-SNL } \\
\text { Tht } \\
\text { nWt } \\
\text { Zc, } \mathrm{Zm}_{1} \text { Op } \\
137, \mathrm{Pl}_{1}\end{array}$ & $\begin{array}{c}\text { CAPP.13-SNL } \\
\text { Tht } \\
n w 1 \\
\text { Zc, } 2 \mathrm{~m}, \mathrm{Op}_{\mathrm{p}} \\
138, \mathrm{Pl}\end{array}$ & $\begin{array}{c}\text { CRPP.14-8NL } \\
\text { Thi } \\
\mathrm{nW} \\
\mathrm{Zc}, \mathrm{Zm}_{1} \mathrm{OP} \\
139, \mathrm{Pl}\end{array}$ & $\begin{array}{c}\text { CRPP. 16-SNI } \\
\text { Thi } \\
\text { nwt } \\
\text { Zc, } \mathrm{Zm}_{1} \mathrm{OP}_{\mathrm{P}} \\
140, \mathrm{P}_{1}\end{array}$ \\
\hline \multicolumn{9}{|c|}{$X(n)$ and Aa Roulte (mix) } \\
\hline & $\begin{array}{l}70.3 \\
0.08 \\
10.0 \\
0.01 \\
0.03 \\
0.38 \\
1.76 \\
1.12 \\
4.28 \\
0.07 \\
10.6\end{array}$ & $\begin{array}{l}70.8 \\
0.08 \\
10.5 \\
0.88 \\
0.05 \\
0.60 \\
2.22 \\
1.44 \\
3.12 \\
0.08 \\
10.8\end{array}$ & $\begin{array}{l}67.0 \\
0.08 \\
11.7 \\
0.08 \\
0.04 \\
0.46 \\
1.86 \\
1.62 \\
4.54 \\
0.08 \\
11.5\end{array}$ & $\begin{array}{l}67.1 \\
0.08 \\
12.1 \\
0.03 \\
0.05 \\
0.22 \\
1.26 \\
0.44 \\
7.60 \\
0.07 \\
10.6\end{array}$ & $\begin{array}{l}68.2 \\
0.08 \\
11.8 \\
0.84 \\
0.04 \\
0.35 \\
1.75 \\
0.81 \\
5.62 \\
0.07 \\
10.8\end{array}$ & $\begin{array}{l}67.4 \\
0.08 \\
11.8 \\
0.06 \\
0.03 \\
0.45 \\
2.15 \\
0.78 \\
4.51 \\
0.07 \\
11.2\end{array}$ & $\begin{array}{l}67.6 \\
0.08 \\
12.0 \\
0.02 \\
0.03 \\
0.47 \\
2.10 \\
0.83 \\
4.44 \\
0.07 \\
11.4\end{array}$ & $\begin{array}{l}67.8 \\
0.08 \\
11.5 \\
0.94 \\
0.10 \\
0.34 \\
2.01 \\
0.85 \\
4.00 \\
0.07 \\
11.1\end{array}$ \\
\hline otal & 100.4 & 100.4 & 100.6 & 100.4 & 100.4 & 99.4 & 99.0 & 99.7 \\
\hline $\begin{array}{l}\text { 8. ppm } \\
\text { Sr ppm }\end{array}$ & $\begin{array}{l}93 \\
70\end{array}$ & $\begin{array}{l}126 \\
108\end{array}$ & $\begin{array}{l}207 \\
180\end{array}$ & $\begin{array}{l}69 \\
17\end{array}$ & $\begin{array}{l}80 \\
100\end{array}$ & $\begin{array}{l}75 \\
52\end{array}$ & $\begin{array}{l}91 \\
88\end{array}$ & $\begin{array}{c}130 \\
42\end{array}$ \\
\hline \multicolumn{9}{|c|}{ WhA Roound (all values pom unlees othorwise notod) } \\
\hline $\begin{array}{l}\ln _{2} \mathrm{O}(\%) \\
\mathrm{H}_{0}(\%) \\
\mathrm{O}_{3}(\%) \\
0(\%) \\
0(\%) \\
\operatorname{li}_{0} \mathrm{O}_{3}(\%)\end{array}$ & $\begin{array}{c}1.23 \pm 0.05 \\
<0.21 \\
11.3 \pm 0.3 \\
447 \pm 38 \\
4.64 \pm 0.30 \\
1.88 \pm 0.12 \\
2.27 \pm 0.12 \\
452 \pm 139 \\
<6 \\
\leq 1.1 \\
266 \pm 11 \\
0.84 \pm 0.05 \\
4.20 \pm 0.23 \\
<230 \\
47 \pm 7 \\
14.0 \pm 3.2 \\
5.5 \pm 0.6 \\
<2.6 \\
<2.15 \\
181 \pm 0 \\
<207 \\
96 \pm 25 \\
<77 \\
<1.7 \\
<0.16 \\
0.37 \pm 0.09 \\
<12 \\
5.17 \pm 0.29 \\
164 \pm 40 \\
25.4 \pm 1.5 \\
57.5 \pm 2.5 \\
26.2 \pm 2.2 \\
4.6 \pm 0.2 \\
0.23 \pm 0.03 \\
0.60 \pm 0.06 \\
4.10 \pm 0.37 \\
2.48 \pm 0.30 \\
0.30 \pm 0.02 \\
3.43 \pm 0.33 \\
1.74 \pm 0.12 \\
40 \pm 5 \\
<0.011 \\
<0.3 \\
19.8 \pm 0.8 \\
3.60 \pm 0.10\end{array}$ & $\begin{array}{c}1.57 \pm 0.07 \\
<0.37 \\
10.6 \pm 0.3 \\
<09 \\
3.32 \pm 0.22 \\
2.43 \pm 0.15 \\
2.26 \pm 0.12 \\
< \pm 146 \\
<6 \\
1.1 \pm 0.3 \\
404 \pm 16 \\
0.81 \pm 0.04 \\
4.59 \pm 0.25 \\
<218 \\
43 \pm 6 \\
<18.7 \\
4.5 \pm 0.5 \\
<2.5 \\
2.10 \pm 0.92 \\
142 \pm 7 \\
<297 \\
126 \pm 25 \\
<74 \\
<1.7 \\
<0.22 \\
0.37 \pm 0.08 \\
<18 \\
4.97 \pm 0.34 \\
158 \pm 18 \\
19.7 \pm 1.1 \\
44.8 \pm 2.0 \\
21.8 \pm 1.0 \\
3.6 \pm 0.2 \\
0.21 \pm 0.03 \\
0.54 \pm 0.06 \\
3.34 \pm 0.35 \\
2.34 \pm 0.17 \\
0.33 \pm 0.02 \\
3.24 \pm 0.17 \\
1.78 \pm 0.12 \\
48 \pm 6 \\
<0.013 \\
<0.3 \\
17.2 \pm 0.7 \\
3.40 \pm 0.10\end{array}$ & $\begin{array}{c}1.52 \pm 0.06 \\
<0.31 \\
12.0 \pm 0.3 \\
105 \pm 21 \\
4.32 \pm 0.28 \\
2.07 \pm 0.14 \\
2.30 \pm 0.12 \\
<4181 \\
<7 \\
<1.5 \\
317 \pm 13 \\
0.86 \pm 0.05 \\
3.89 \pm 0.26 \\
<260 \\
29 \pm 5 \\
16.7 \pm 3.7 \\
5.3 \pm 0.6 \\
<3.6 \\
<3.43 \\
155 \pm 8 \\
218 \pm 77 \\
123 \pm 26 \\
<6 \\
<2.1 \\
<0.24 \\
0.47 \pm 0.09 \\
<18 \\
3.78 \pm 0.22 \\
211 \pm 86 \\
32.3 \pm 1.8 \\
60.3 \pm 2.8 \\
23.1 \pm 2.0 \\
5.8 \pm 0.3 \\
0.27 \pm 0.03 \\
0.71 \pm 0.07 \\
4.38 \pm 0.49 \\
2.46 \pm 0.21 \\
0.30 \pm 0.02 \\
3.62 \pm 0.28 \\
1.66 \pm 0.11 \\
29 \pm 4 \\
<0.014 \\
<0.5 \\
20.7 \pm 0.8 \\
3.60 \pm 0.10\end{array}$ & $\begin{array}{c}0.46 \pm 0.02 \\
<0.23 \\
12.4 \pm 0.4 \\
<82 \\
7.49 \pm 0.47 \\
1.23 \pm 0.10 \\
2.41 \pm 0.13 \\
<3833 \\
<6 \\
<1.4 \\
418 \pm 17 \\
0.85 \pm 0.05 \\
4.44 \pm 0.25 \\
<100 \\
37 \pm 6 \\
18.4 \pm 3.0 \\
4.6 \pm 0.5 \\
<3.0 \\
<1.27 \\
248 \pm 12 \\
<233 \\
108 \pm 23 \\
<64 \\
<2.3 \\
<0.18 \\
0.30 \pm 0.06 \\
<16 \\
5.28 \pm 0.33 \\
101 \pm 46 \\
34.9 \pm 2.0 \\
69.9 \pm 3.4 \\
34.9 \pm 3.2 \\
6.3 \pm 0.3 \\
0.33 \pm 0.02 \\
0.80 \pm 0.08 \\
5.30 \pm 0.69 \\
2.68 \pm 0.18 \\
0.33 \pm 0.02 \\
3.68 \pm 0.22 \\
1.71 \pm 0111 \\
37 \pm 5 \\
<0.007 \\
<0.5 \\
23.6 \pm 0.9 \\
3.30 \pm 0.10\end{array}$ & $\begin{array}{c}0.81 \pm 0.04 \\
0.28 \pm 0.08 \\
12.2 \pm 0.4 \\
144 \pm 34 \\
6.18 \pm 0.39 \\
1.74 \pm 0.12 \\
2.34 \pm 0.12 \\
520 \pm 157 \\
<6 \\
<1.5 \\
334 \pm 14 \\
0.86 \pm 0.05 \\
3.41 \pm 0.24 \\
<225 \\
33 \pm 6 \\
16.3 \pm 2.9 \\
3.9 \pm 0.5 \\
<3.7 \\
<1.22 \\
181 \pm 0 \\
<227 \\
113 \pm 27 \\
<70 \\
<2.0 \\
<0.16 \\
<0.23 \\
<13 \\
4.64 \pm 0.28 \\
<272 \\
20.4 \pm 1.2 \\
40.0 \pm 1.8 \\
22.7 \pm 2.3 \\
3.6 \pm 0.2 \\
0.19 \pm 0.01 \\
0.47 \pm 0.06 \\
3.36 \pm 0.33 \\
2.11 \pm 0.15 \\
0.28 \pm 0.01 \\
3.56 \pm 0.38 \\
1.58 \pm 0.11 \\
20 \pm 4 \\
<0.010 \\
<0.4 \\
22.2 \pm 0.9 \\
2.70 \pm 0.10\end{array}$ & $\begin{array}{c}0.82 \pm 0.04 \\
<0.33 \\
12.2 \pm 0.4 \\
<84 \\
4.94 \pm 0.32 \\
2.17 \pm 0.16 \\
2.68 \pm 0.14 \\
<3696 \\
<6 \\
<1.2 \\
276 \pm 12 \\
0.82 \pm 0.05 \\
6.04 \pm 0.33 \\
<192 \\
54 \pm 8 \\
15.6 \pm 3.0 \\
3.2 \pm 0.4 \\
<2.9 \\
1.89 \pm 0.72 \\
179 \pm 0 \\
<260 \\
118 \pm 28 \\
<64 \\
<1.9 \\
<0.19 \\
0.29 \pm 0.06 \\
<16 \\
4.78 \pm 0.29 \\
<81 \\
18.9 \pm 1.0 \\
40.4 \pm 1.8 \\
17.0 \pm 1.5 \\
3.3 \pm 0.2 \\
0.23 \pm 0.03 \\
0.41 \pm 0.06 \\
<5.62 \\
1.62 \pm 0.13 \\
0.24 \pm 0.01 \\
3.78 \pm 0.25 \\
1.86 \pm 0.12 \\
37 \pm 5 \\
<0.010 \\
<0.4 \\
21.5 \pm 0.8 \\
2.50 \pm 0.10\end{array}$ & $\begin{array}{c}0.82 \pm 0.03 \\
0.46 \pm 0.08 \\
12.5 \pm 0.4 \\
\leq 82 \\
4.68 \pm 0.30 \\
2.17 \pm 0.14 \\
2.34 \pm 0.12 \\
<3884 \\
<6 \\
2.0 \pm 0.4 \\
267 \pm 11 \\
0.84 \pm 0.05 \\
4.13 \pm 0.27 \\
<214 \\
32 \pm 6 \\
13.4 \pm 3.1 \\
4.6 \pm 0.6 \\
<3.5 \\
<2.60 \\
172 \pm 8 \\
<260 \\
<97 \\
<70 \\
<2.1 \\
<0.20 \\
0.16 \pm 0.05 \\
<15 \\
4.52 \pm 0.26 \\
118 \pm 50 \\
26.8 \pm 1.8 \\
51.3 \pm 2.3 \\
17.9 \pm 1.6 \\
5.3 \pm 0.2 \\
0.25 \pm 0.02 \\
0.54 \pm 0.06 \\
4.73 \pm 0.46 \\
2.02 \pm 0.15 \\
0.31 \pm 0.02 \\
3.47 \pm 0.29 \\
1.67 \pm 0.12 \\
39 \pm 5 \\
<0.011 \\
<0.4 \\
20.7 \pm 0.8 \\
2.50 \pm 0.10\end{array}$ & $\begin{array}{c}0.85 \pm 0.04 \\
<0.28 \\
11.7 \pm 0.3 \\
<100 \\
4.82 \pm 0.31 \\
1.00 \pm 0.14 \\
2.45 \pm 0.13 \\
456 \pm 166 \\
<8 \\
<1.4 \\
780 \pm 33 \\
0.88 \pm 0.06 \\
4.46 \pm 0.25 \\
<245 \\
43 \pm 8 \\
19.2 \pm 3.6 \\
6.7 \pm 0.8 \\
<3.4 \\
<2.20 \\
187 \pm 0 \\
<308 \\
121 \pm 24 \\
<85 \\
<2.3 \\
<0.22 \\
0.27 \pm 0.08 \\
<21 \\
4.60 \pm 0.27 \\
<195 \\
30.6 \pm 2.0 \\
81.4 \pm 3.6 \\
31.1 \pm 2.7 \\
6.7 \pm 0.3 \\
0.31 \pm 0.04 \\
0.84 \pm 0.10 \\
6.03 \pm 0.54 \\
3.88 \pm 0.24 \\
0.40 \pm 0.03 \\
3.68 \pm 0.17 \\
1.67 \pm 0.14 \\
30 \pm 4 \\
<0.008 \\
<0.5 \\
22.7 \pm 0.9 \\
3.90 \pm 0.10\end{array}$ \\
\hline
\end{tabular}


APPENDIX C. (cont)

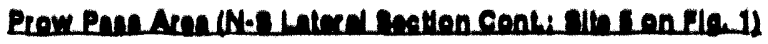

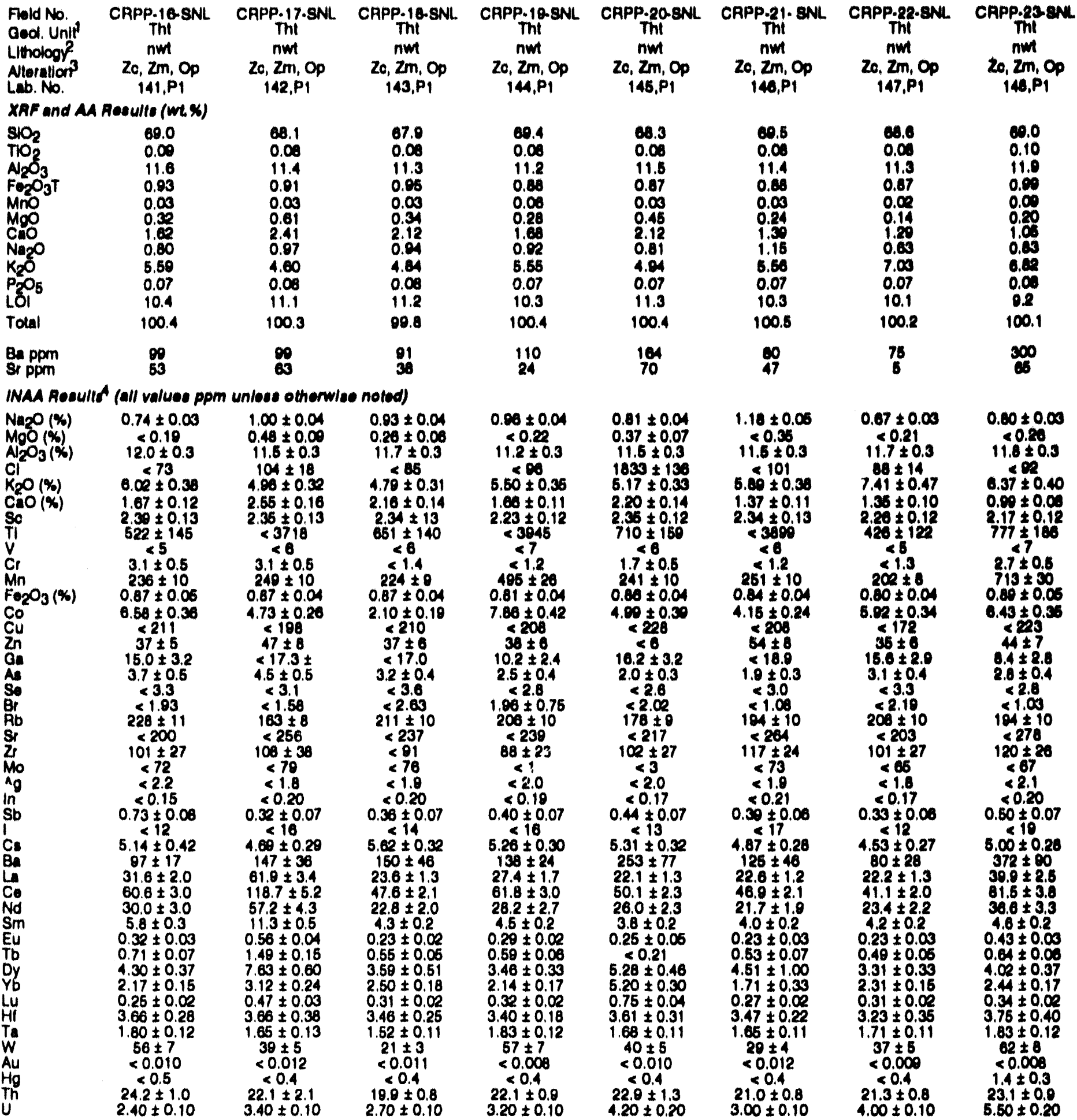


APPENDIX C. (cont)

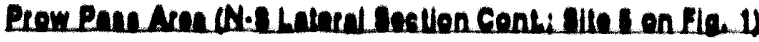

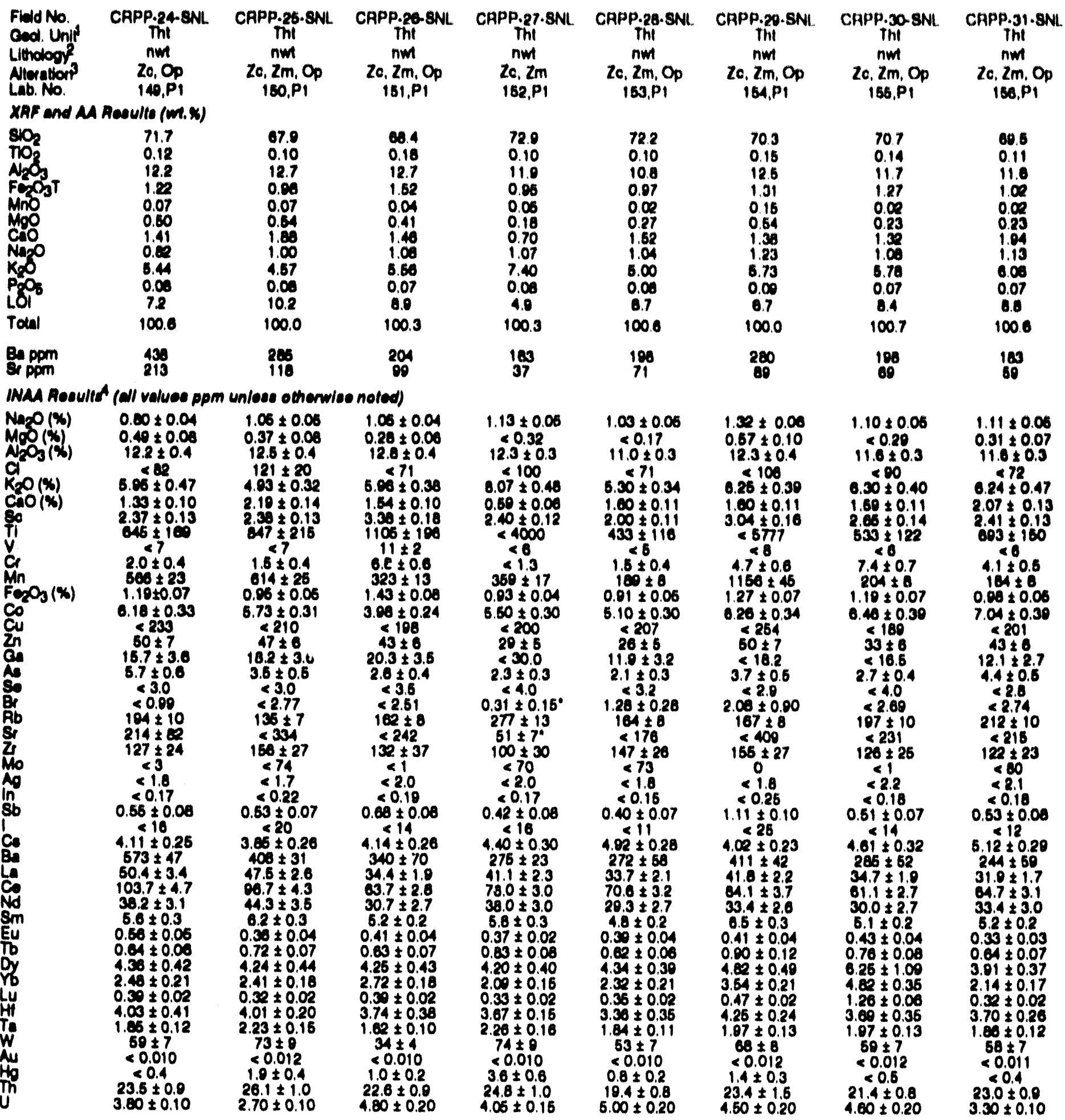


APPENDIX C. (cont)

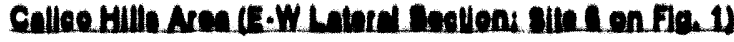

\begin{tabular}{|c|c|c|c|c|c|c|c|c|}
\hline $\begin{array}{l}\text { Fiold No } \\
\text { Ocol. Unit' } \\
\text { Litholog? } \\
\text { Nitorationt } \\
\text { Lab. No. }\end{array}$ & 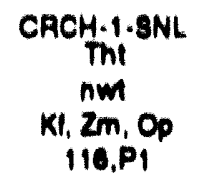 & 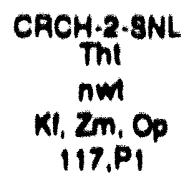 & 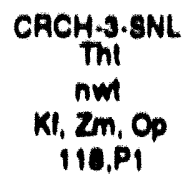 & 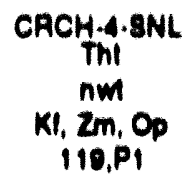 & 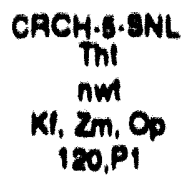 & 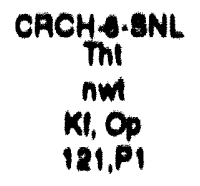 & 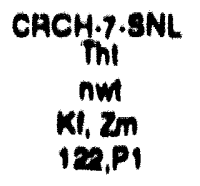 & 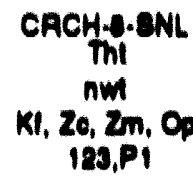 \\
\hline \multicolumn{9}{|c|}{ XRF and AA Rooulto (Wt: $x)$} \\
\hline 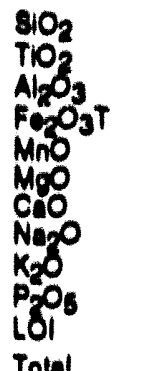 & $\begin{array}{l}72.2 \\
0.11 \\
12.3 \\
1.29 \\
0.12 \\
0.00 \\
1.17 \\
0.70 \\
0.01 \\
0.07 \\
7.1 \\
100.1\end{array}$ & $\begin{array}{l}73.7 \\
0.12 \\
11.0 \\
1.12 \\
0.04 \\
0.34 \\
0.06 \\
0.40 \\
7.90 \\
0.07 \\
4.2\end{array}$ & $\begin{array}{l}73.3 \\
0.11 \\
11.0 \\
0.00 \\
0.04 \\
0.20 \\
1.04 \\
0.01 \\
0.26 \\
0.00 \\
3.0\end{array}$ & $\begin{array}{l}70.7 \\
0.11 \\
10.7 \\
1.10 \\
0.03 \\
0.00 \\
2.35 \\
0.61 \\
0.73 \\
0.00 \\
7.1 \\
1000\end{array}$ & $\begin{array}{l}70.0 \\
0.11 \\
12.8 \\
0.70 \\
0.18 \\
0.10 \\
0.90 \\
0.75 \\
0.90 \\
0.07 \\
4.6 \\
0.9\end{array}$ & $\begin{array}{l}74.7 \\
0.12 \\
11.0 \\
1.10 \\
0.06 \\
0.90 \\
0.60 \\
0.40 \\
7.70 \\
0.07 \\
3.2 \\
1.29\end{array}$ & $\begin{array}{l}74.6 \\
0.10 \\
11.2 \\
1.10 \\
0.09 \\
0.93 \\
0.4 \\
0.48 \\
7.75 \\
0.00 \\
4.1\end{array}$ & $\begin{array}{l}71.7 \\
0.00 \\
12.0 \\
1.39 \\
0.18 \\
0.20 \\
8.96 \\
0.61 \\
7.10 \\
0.07 \\
6.0 \\
0.9\end{array}$ \\
\hline tw & 100.3 & 100.6 & 100.2 & 100.0 & 90.7 & 100.1 & 100.2 & 60 \\
\hline $\begin{array}{l}\text { 3a ppm } \\
\text { sppmm }\end{array}$ & $\begin{array}{l}70 \\
40\end{array}$ & $\begin{array}{l}97 \\
30\end{array}$ & $\begin{array}{l}130 \\
37\end{array}$ & $\begin{array}{l}117 \\
60\end{array}$ & $\begin{array}{l}110 \\
40\end{array}$ & $\begin{array}{l}100 \\
20\end{array}$ & 87 & $\begin{array}{l}216 \\
104\end{array}$ \\
\hline \multicolumn{9}{|c|}{ 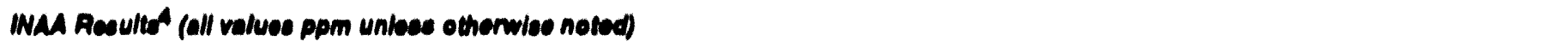 } \\
\hline 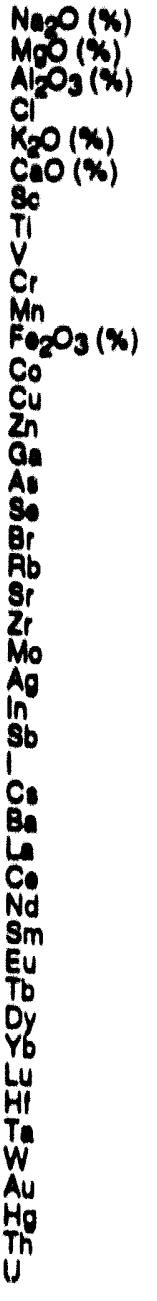 & 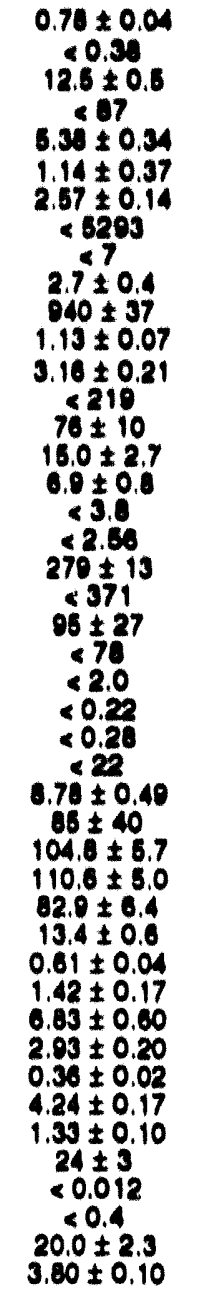 & 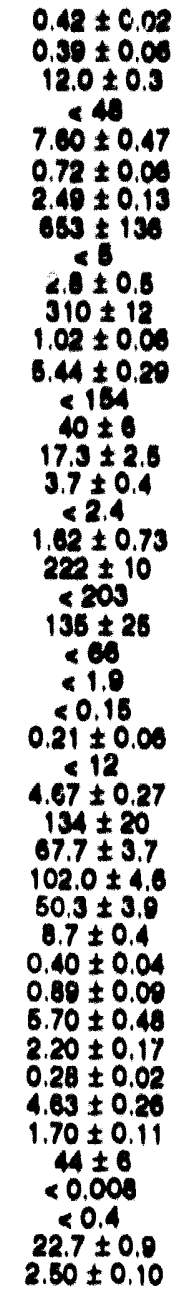 & 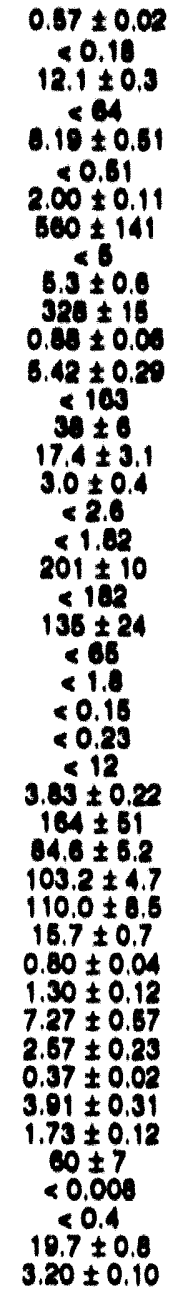 & 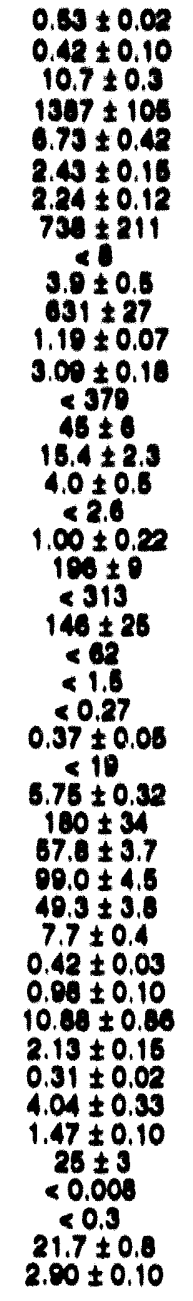 & 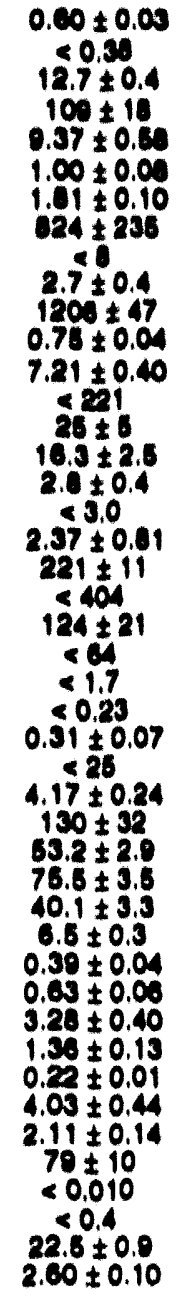 & 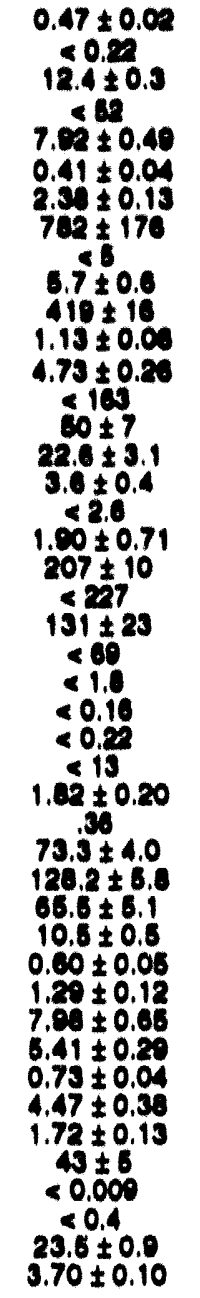 & 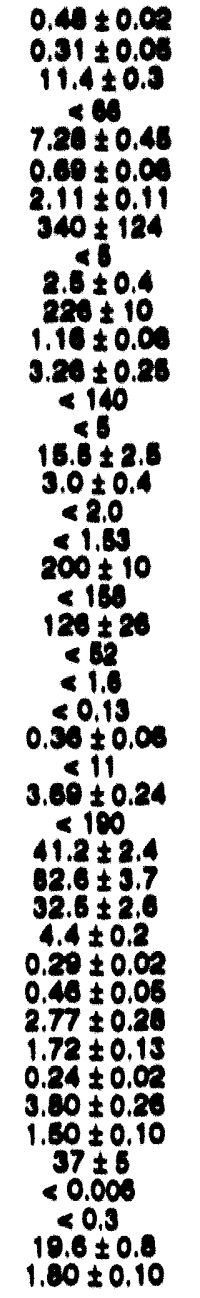 & 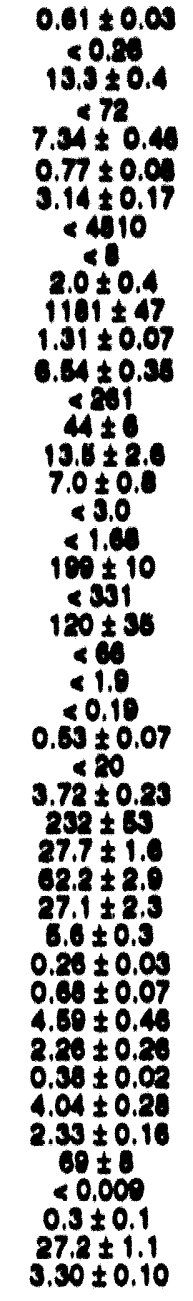 \\
\hline
\end{tabular}


Amineix C. (cong)

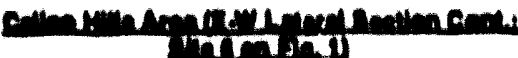

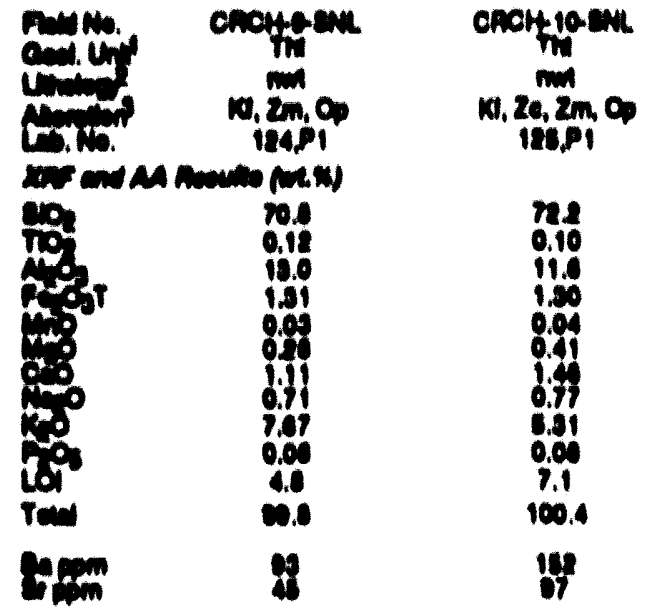

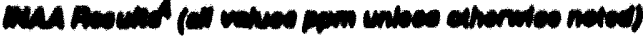

No(x) $\quad 0.77 \div 0.09 \quad 0.01 \pm 0.09$

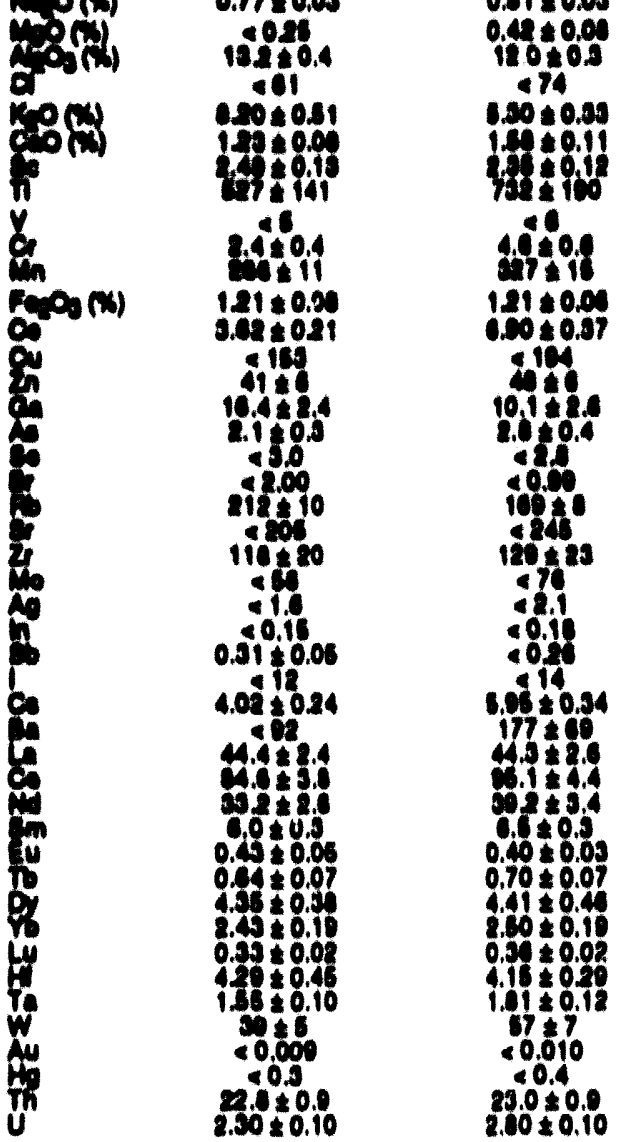

\section{E...m}

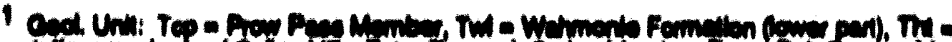

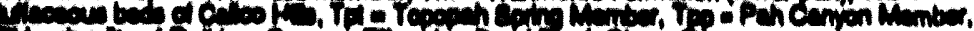

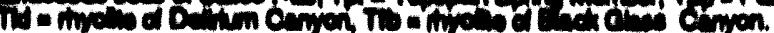

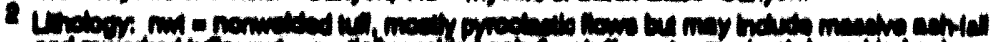

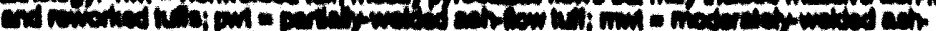

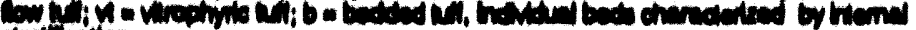

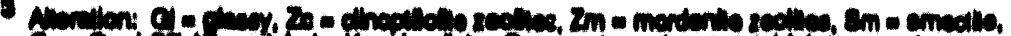

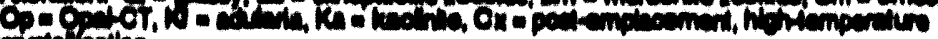

\section{criviontion.}

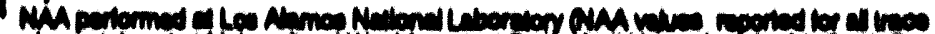

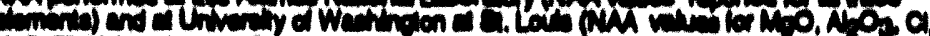

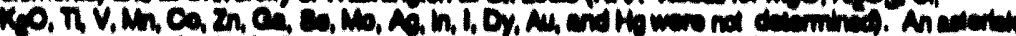

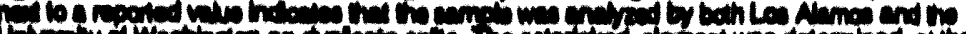

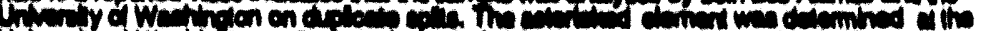

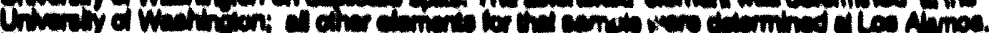

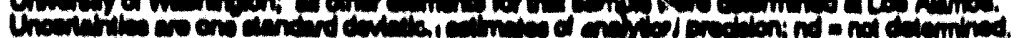

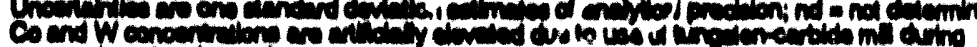
menen of rock powders. 
APPENDIX D.

SAMPLE KEY AND LOCATIONS FOR VITRIC AND ZEOLITIC TUTTS INVESTIGATED FOR A SURFACE -BASED TEST FACILITY, YUCCA MOUNTAIN, NEVADA

Disla:

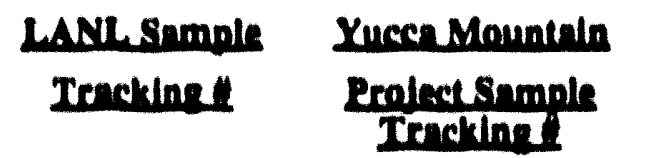

Neyndasinte

Neyndinsente

Conrellente( (in.)

Comrolinina (II.)

Busted Butte (Southeastern End)

DFB 3/90-4

160

DEB 3/90.5

161

DEB 3/90.6

162

DEB 3/90-7

163

DEB 3/90-8

164

DEB 3/90-9

165

DEB 3/90-10

166

$\operatorname{sPCO0002129}$

573123

737356

SPCO0002130

573092

737429

SPCO0002131

573082

737459

SPC 00002132

573047

737526

SPCO0002133

573041

737524

SPCO0002134

573022

737565

572971

737616

Busted Bute (Northern Rind)

DHB 3/90-44

$2(0)$

DEB 3/90.45

201

DEB 3/90-46

202

DEB 3/90-47

203

DEB 3/90-48

204

DEB 3/90-49

205

DKB 3/90)-50

206

DFEB 4/91.1

432

SPCO0002135

SPC00002169

573319

742622

S1PCO0002170

573258

742585

S1PCOOX02171

573217

742542

SIPCO0002172

573218

742497

SPC 00002173

573200

742498

SPCO0002174

573186

742468

SPCO0002175

573173

742456

SPCO0X005361

$\mathbf{5 7 3 0 6 0}$

742509

Northeast Yucca Mountain Area

DEB 5/91.7

DEB $5 / 91.8$

DEB $5 / 91.9$

DFB $5 / 91 \cdot 10$

DFE $5 / 91 \cdot 12$

DEB $5 / 91-11$

DEB 3/9()-36

DEB 3/90-37
438

439

440

441

443

442

192

193
SICCOOX05367

SPCOOOON5368

SIPCOOOOS369

SPCO000 5370

SPCO0005372

SIPCO0005371

SICCOCXO2161

$\mathrm{SICCOOO2} 162$
562285

562285

562210

562135

562959

562135

563110

562955
780373

780299

780224

780224

779851

780149

779585

779810 


\begin{tabular}{|c|c|c|c|c|}
\hline \multicolumn{5}{|c|}{ APPENDIX D. (cont) } \\
\hline Fisld: & $\begin{array}{l}\text { LANL_Snmple } \\
\text { Trending }\end{array}$ & 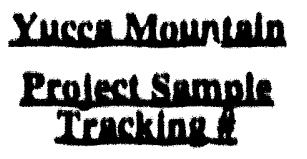 & $\begin{array}{l}\text { Nerndessente } \\
\frac{\text { Coordinute (a) }}{\text { ind }}\end{array}$ & $\begin{array}{l}\text { Narradusinte } \\
\frac{\text { Coordinnte(N) }}{\text { (ind) }}\end{array}$ \\
\hline DEB 3/90-38 & 194 & $\operatorname{sic}(000 \times 12163$ & 562887 & 779516 \\
\hline DEB 3/90-39 & 195 & $\operatorname{sic}(x)(x) 2164$ & 562817 & 779410 \\
\hline DEB 3/90-40 & 196 & $\operatorname{slc} C 00002165$ & 562743 & 779317 \\
\hline DEB 3/90-41 & 197 & $\operatorname{sPC}(x \times 02166$ & 562701 & 779263 \\
\hline DEB 3/90-42 & 198 & $\operatorname{si}{ }^{2} \mathrm{COx} \times 02167$ & 562651 & 779206 \\
\hline DEB 3/90-43 & 199 & SICCOXXX)2168 & 562703 & 779156 \\
\hline DEB $5 / 91 \cdot 13$ & 444 & siccoxxos373 & 563933 & 778209 \\
\hline DEB $9 / 91-14$ & 445 & SPCOXOX05374 & $564 \times 007$ & 778209 \\
\hline DEB 5/91-15 & 446 & sircoxoxos375 & 564007 & 778134 \\
\hline \multicolumn{5}{|c|}{ Stagecoach Road Area } \\
\hline DEB 3/90-1 & 157 & $\mathrm{SPCOOOO2126}$ & 564198 & 724492 \\
\hline DEB 3/90.2 & 158 & $\operatorname{SPCOOXO2127}$ & 564335 & 724534 \\
\hline DEB 3/90-3 & 159 & $\operatorname{sPC}(000) 2128$ & 564614 & 724945 \\
\hline \multicolumn{5}{|c|}{ Prow Pass (Southern Vertical Section) } \\
\hline DEB 3/90-11 & 167 & $\operatorname{sPC}(x \times x \times 2136$ & 550319 & 784766 \\
\hline DEB 3/90-12 & 168 & $S P C O X X X) 2137$ & 550373 & 784774 \\
\hline DEB 3/90.13 & 169 & $\operatorname{Sic}(O O X) 2138$ & 550419 & 784776 \\
\hline DEB 3/90.14 & 170 & $\operatorname{SPCOXXX)2139}$ & 550457 & 784807 \\
\hline DEB 3/90-15 & 171 & $\operatorname{SPCOXOOO2140}$ & 550496 & 784831 \\
\hline DEB 3/90.16 & 172 & $\operatorname{sic}(00 \times) 2141$ & 550540 & 784839 \\
\hline DEB 3/90-17 & 173 & $\operatorname{SPC}(X X)(1142$ & 550592 & 784877 \\
\hline DEB 3/90.18 & 174 & SPCOXOOO2143 & 550620 & 784904 \\
\hline DEB 3/90.19 & 175 & $\operatorname{SPCOOOOO2144}$ & 550650 & 784912 \\
\hline DEB 3/90-20 & 176 & $\operatorname{sPCOOX02145}$ & 550676 & 784932 \\
\hline DEB 3/90-21 & 177 & $\operatorname{sic} C(x \times 02146$ & 550714 & 784948 \\
\hline DEB 3/90-22 & 178 & $\operatorname{SPCOOOO12147}$ & 550738 & 784976 \\
\hline DEB 3/90-23 & 179 & $\operatorname{sPC} 00002148$ & 550764 & 784990 \\
\hline DEB 3/90-24 & 180 & $\mathrm{SPC}(00002149$ & 550790 & 7850009 \\
\hline DEB 3/90-25 & 181 & SPCO0002150 & 550843 & 785029 \\
\hline DEB 3/90-26 & 182 & $S P C 00002151$ & 550887 & 785053 \\
\hline DEB 3/90-27 & 183 & $\mathrm{SP}^{2} \mathrm{COOOO2152}$ & 550919 & 7850.57 \\
\hline DEB 3/90-28 & 184 & SPCOOOC?:153 & 550955 & 785077 \\
\hline
\end{tabular}




\begin{tabular}{|c|c|c|c|c|}
\hline \multicolumn{5}{|c|}{ APPENDIX D. (cont) } \\
\hline Field\#\# & $\begin{array}{l}\text { LANL Sample } \\
\text { Tracking\# }\end{array}$ & $\begin{array}{l}\text { YuccaMountain } \\
\text { Project Sample } \\
\text { Tracking\# }\end{array}$ & $\begin{array}{l}\text { Neyadastate } \\
\frac{\text { Coordinate (E) }}{\text { (ft.) }}\end{array}$ & $\begin{array}{c}\text { Nevada State } \\
\text { Coordinate }(\mathbf{N}) \\
\text { (ft.) }\end{array}$ \\
\hline DEB 3/90-29 & 185 & SPC00002154 & 550967 & 785081 \\
\hline DEB 3/90-30 & 186 & SPC00002155 & 550981 & 785092 \\
\hline DEB 3/90-31 & 187 & SPC00002156 & 550999 & 785084 \\
\hline DEB 3/90-32 & 188 & SPC00002157 & 551017 & 785154 \\
\hline DEB 3/90-33 & 189 & SPC 00002158 & 551053 & 785100 \\
\hline DEB 3/90-34 & 190 & SPC00002159 & 551096 & 785102 \\
\hline DEB 3/90-35 & 191 & SPC00002160 & 551108 & 785118 \\
\hline \multicolumn{5}{|c|}{ Prow Pass Area (Central Vertical Section) } \\
\hline $3-15-82-1$ & 82 & & 550749 & 786716 \\
\hline $3-15-82-2$ & 83 & & 550899 & 786567 \\
\hline $3-15-82-3$ & 84 & & 550899 & 786567 \\
\hline $3-15-82-4$ & 85 & & 550974 & 786493 \\
\hline $3-15-82-5$ & 86 & & 550974 & 786493 \\
\hline $3-15-82-6$ & 87 & & 551049 & 786418 \\
\hline $3-15-82-7$ & 88 & & 551124 & 786343 \\
\hline $3-15-82-8$ & 89 & & 551124 & 786343 \\
\hline $3-15-82-9$ & 90 & & 551273 & 786642 \\
\hline $3-15-82-10$ & 91 & & 551348 & 786493 \\
\hline $3-15-82-11$ & 92 & & 551348 & 786418 \\
\hline \multicolumn{5}{|c|}{ Prow Pass Area (Northern Vertical Section) } \\
\hline $82 \mathrm{FB}-1$ & 110 & & 549625 & 789851 \\
\hline $82 \mathrm{FB}-2$ & 111 & & 549625 & 790299 \\
\hline $82 \mathrm{FB}-3 \mathrm{a}$ & 112 & & 549775 & 790448 \\
\hline $82 \mathrm{FB}-3 \mathrm{~b}$ & 113 & & 549775 & 790448 \\
\hline $82 \mathrm{FB}-4$ & 114 & & 549925 & 790672 \\
\hline $82 \mathrm{FB}-5$ & 115 & & 550225 & 790896 \\
\hline \multicolumn{5}{|c|}{ Prow Pass Area (N-S Lateral Section; Locations from Rautman, 1991) } \\
\hline CRPP-1-SNL & 126 & & 550696 & 783540 \\
\hline CRPP-2-SNL & 127 & & 550747 & 783795 \\
\hline CRPP-3-SNL & 128 & & 550787 & 783996 \\
\hline
\end{tabular}




\section{Eleld:\#}

CRPP-4-SNL

CRPP-5-SNL

CRPP-6-SNL

CRPP-7-SNL

CRPP-8-SNL

CRPP-9-SNL

CRPP-10-SNL

CRPP-11-SNL

CRPP-12-SNL

CRPP-13-SNL

CRPP-14-SNL

CRPP-15-SNL

CRPP-16-SNL

CRPP-17-SNL

CRPP-18-SNL

CRPP-19-SNL

CRPP-20-SNL

CRPP-21-SNL

CRPP-22-SNL

CRPP-23-SNL

CRPP-24-SNL

CRPP-25-SNL

CRPP-26-SNL

CRPP-27-SNL

CRPP-28-SNL

CRPP-29-SNL

CRPP-30-SNL

CRPP-31-SNL

APPENDIX D. (cont)

$\begin{array}{cccc}\text { LANLSample } & \text { YuccaMountain } \\ \text { Tracking\# } & \begin{array}{c}\text { Project Sample } \\ \text { Tracking\# }\end{array} & \frac{\text { Coordinate (E) }}{\text { (ft.) }} & \begin{array}{c}\text { NevadaState } \\ \text { Coordinate (N) }\end{array} \\ & \text { (ft.) } & & \end{array}$

129

130

131

132

133

134

135

136

137

138

139

140

141

142

143

144

145

146

147

148

149

150

151

152

153

154

155

156
550816

550857

550898

550935

550995

550975

551008

551086

551126

551179

551210

551247

551290

551333

551363

551386

551416

551445

551485

551524

551765

551500

551584

551689

551777

551827

551923

552003
784138

784344

784550

784737

784835

784933

785099

785492

785688

785953

786110

786296

786512

786727

786874

786992

787139

787286

787483

787678

788885

787650

787596

787527

787470

787437

787375

787323

Calico Hills Area (E-W Lateral Section; Locations from Rautman, 1991)

$\begin{array}{ll}\text { CRCH-1-SNL } & 116 \\ \text { CRCH-2-SNL } & 117 \\ \text { CRCH-3-SNL } & 118\end{array}$

591800

775300

775300

591700

775300 


\begin{tabular}{|c|c|c|c|c|}
\hline \multicolumn{5}{|c|}{ APPENDIX D. (cont) } \\
\hline Field\# & $\frac{\text { LANL_Sample }}{\text { Tracking \# }}$ & $\begin{array}{l}\text { Yucca Mountain } \\
\text { Project Sample } \\
\text { Tracking\# }\end{array}$ & $\begin{array}{c}\text { Neyadastate } \\
\text { Coordinate (E) } \\
\text { (ft) }\end{array}$ & $\begin{array}{c}\text { Neyadastate } \\
\text { Coordinate (N) } \\
\text { (fit.) }\end{array}$ \\
\hline CRCH-4-SNL & 119 & & 591400 & 775300 \\
\hline CRCH-5-SNL & 120 & & 591300 & 775300 \\
\hline CRCH-6-SNL & 121 & & 591203 & 775300 \\
\hline CRCH-7-SNL & 122 & & 591000 & 775300 \\
\hline CRCH-8-SNL & 123 & & 590800 & 775300 \\
\hline CRCH-9-SNL & 124 & & 590695 & 775300 \\
\hline CRCH-10-SNL & 125 & & 590615 & 775300 \\
\hline
\end{tabular}




\section{APPENDIX E}

DATA SOURCES

Field Notebooks:

TWS-ESS-1-6/88-5, pp. 137-160.

TWS-EES-1-9-89-27, pp. 82-92 and p. 101.

Laboratory Notebooks:

TWS-ESS-1-2/88-20, pp. 27-46 and pp. 54-147.

TWS-EES-1-9-90-16, pp. 1-141.

TWS-ESS-1-6-90-7, pp. 1-167.

TWS-EES-1-2-92-5, pp.32-47.

\section{Maps:}

TWS-EES-1-5-92-5

TWS-EES-1-5-92-6

TWS-EES-1-5-92-7

Data File Locations for XRD analyses shown on following pages. 


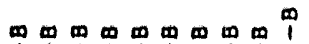

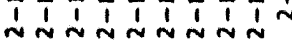

in in in in in in

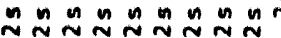
n in in n in in $\begin{array}{lllllllll}1 & 1 & 1 & 1 & 1 & 1 & 1 & 1 & 1\end{array}$

ㅇㅇㅇㅇㅇㅇㅇㅇ

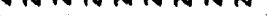
$\ddot{0} \ddot{0} 0 \ddot{0} \ddot{0} \ddot{0} \ddot{0} \ddot{0} \ddot{0}$ $m m m m m m m \hat{~}$

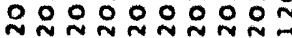

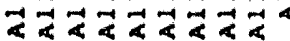

$t+4+4+4+$ - $<0<<<<<\frac{1}{4}$

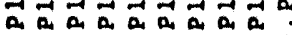
on a a o in m $-4 \omega^{\infty} N N N N N$

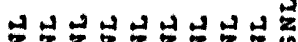
$z z z z z z z=$ i ? 4nm

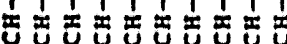

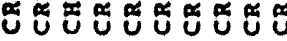

0000000000 NNNNNNmNN

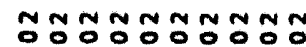

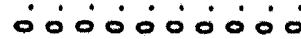
용ㅇ:용ㅇㅇ

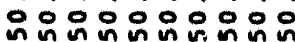

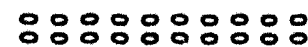
nnNmNnnNin

응ㅇㅇㅇㅇㅇㅇㅇㅇㅇ ín

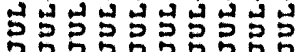

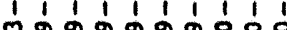

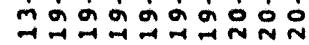

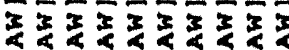

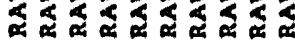
$\omega \omega \omega \omega \omega \omega \omega \omega \omega$

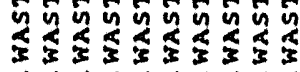
- 0000000 00

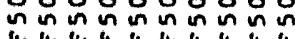

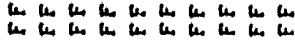

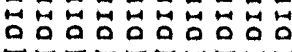

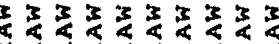

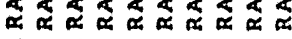

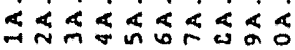

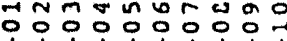

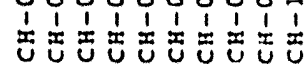

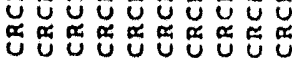

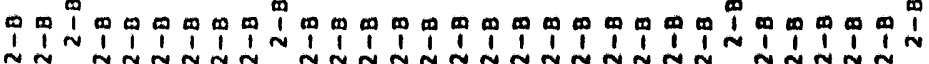

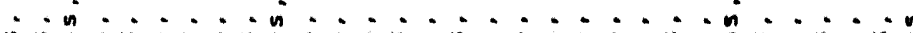

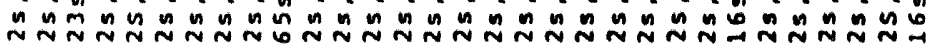

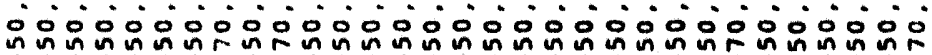

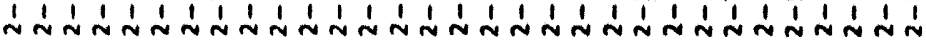

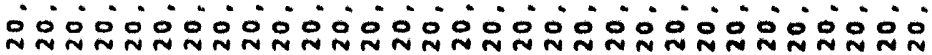

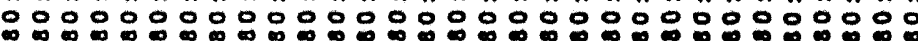
م

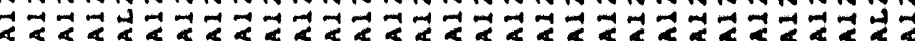

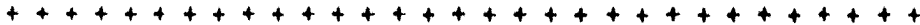

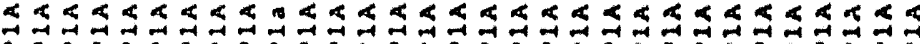

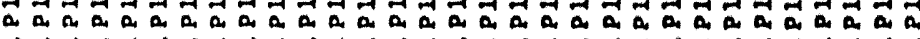
bNa 0 in

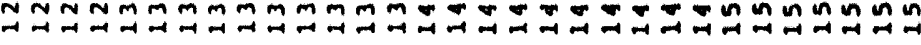

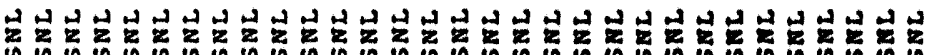

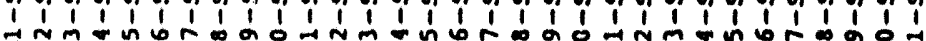

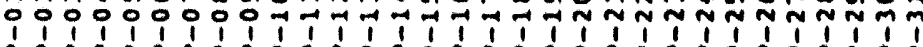

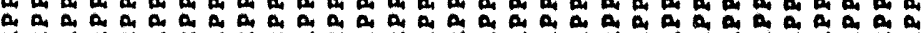

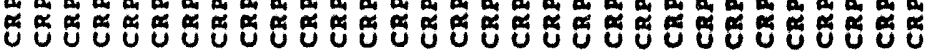
0000000000000000000000000000000

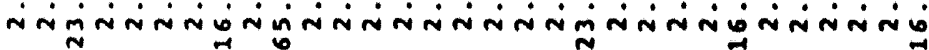

N N

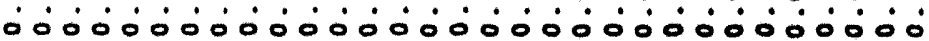

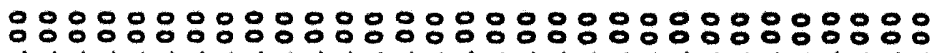

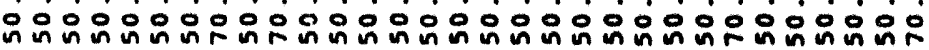

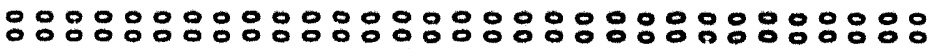
N

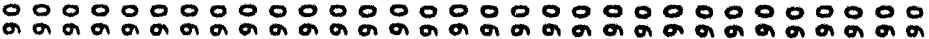
لـ

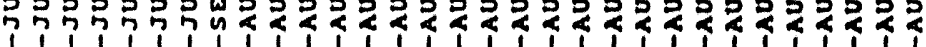
N

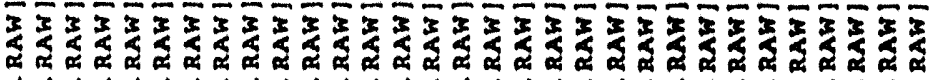

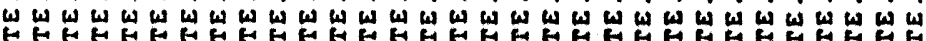
yุy

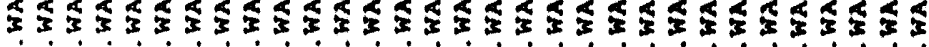
0000000000000000000000000000000

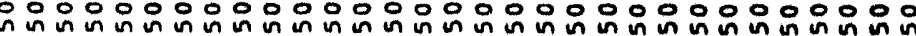

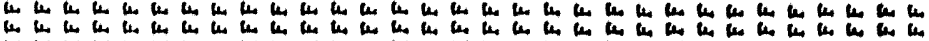

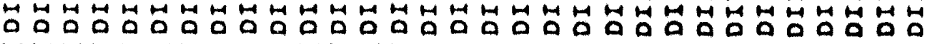

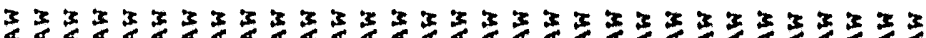

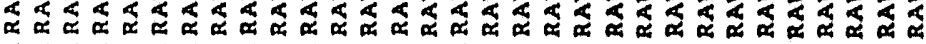

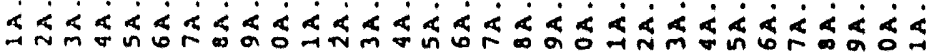

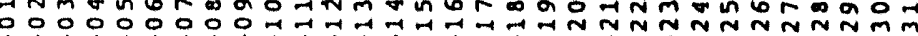

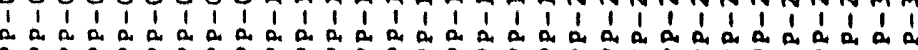

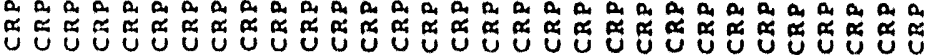

m

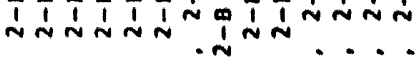
in is in in in in n $n$ N

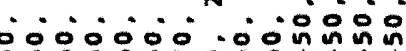

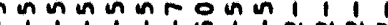

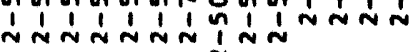

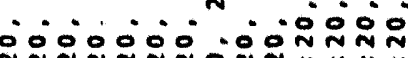

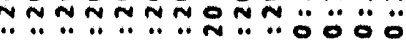
붕ㅎㅂ mตำ N

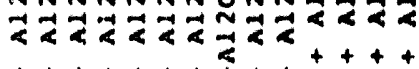
$<<<<<<<<\leqslant<\leqslant \leq \leqslant \leq$

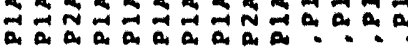
$\because$ - . - or or o o

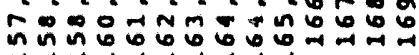

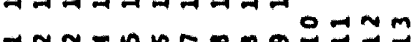
11

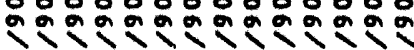
immmmmmmmmmm

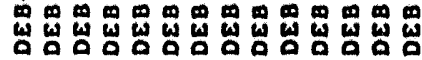
o o o o o o o o o o o o o o NiñNi $\dot{N} \dot{N} \dot{N} \dot{N} \dot{N}$

TOO

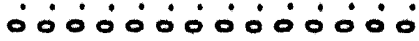

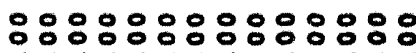

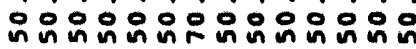

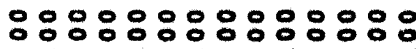

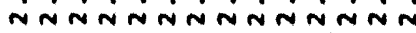

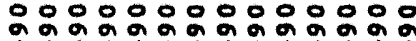
乌ئ

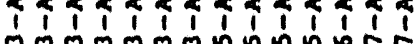

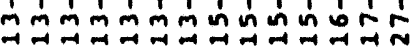

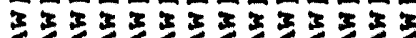

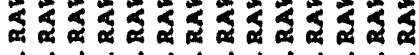

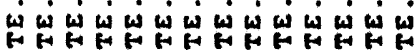

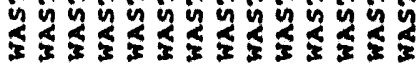

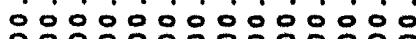

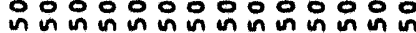

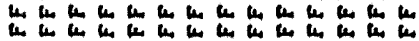

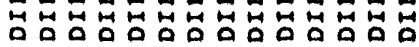

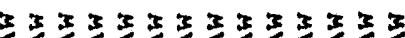

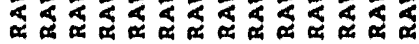

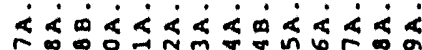

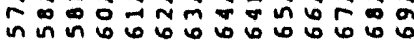

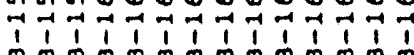

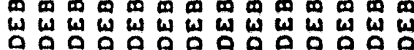




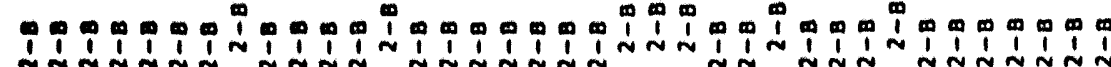

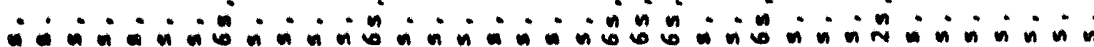
ผ

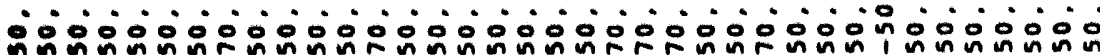

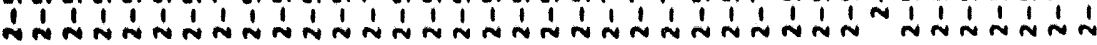

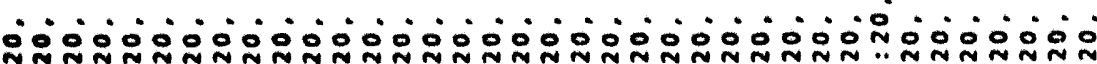

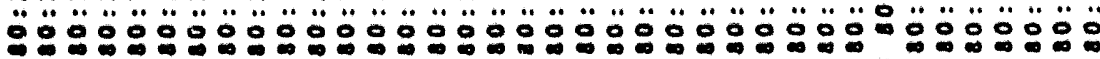

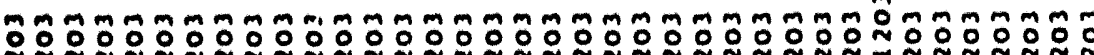

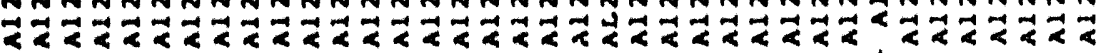
$++++++++++++++++++++++++++++++++1++++++$

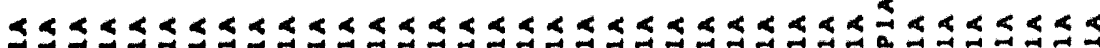
a a a a a a a a a a a a a a a a a a a a a a a a a a a a a

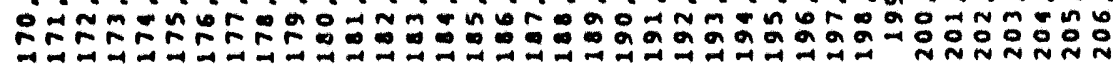

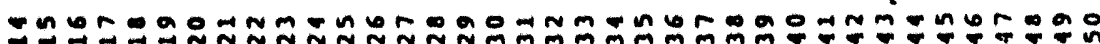
'́! ’́

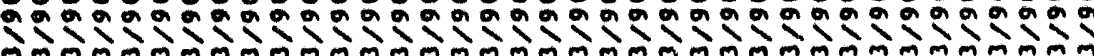

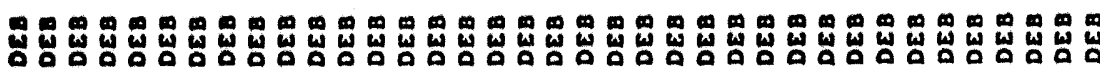

0000000000000000000000000000000000000

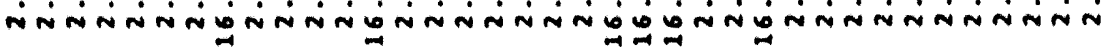

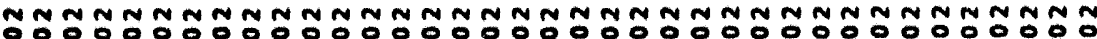
-00000000000000000000000000000000000

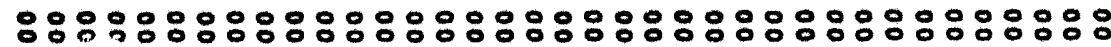

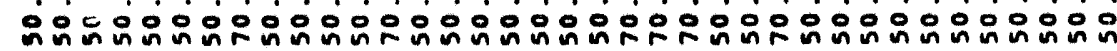

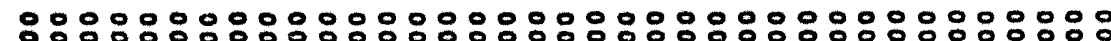

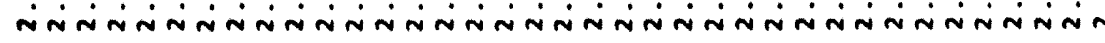

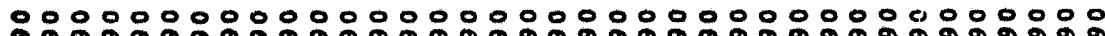

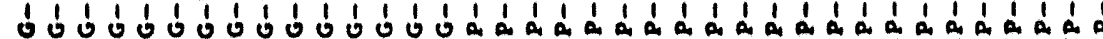

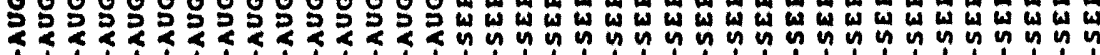

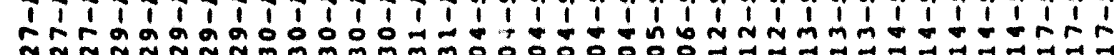

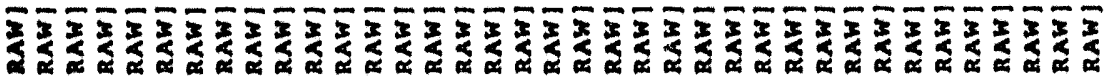

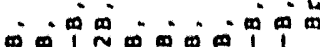

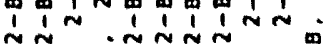
$\therefore \dot{n} n_{0}^{n} \ldots \dot{n} \dot{n}$

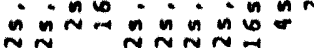
-000 $00^{n}$

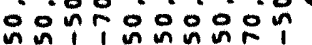

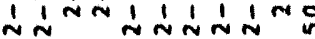
- $000 . \cdots 00$

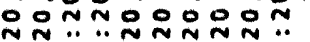

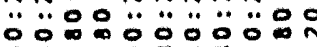

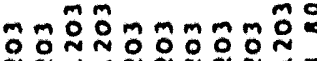

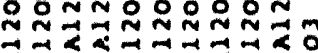

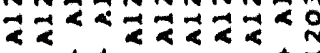

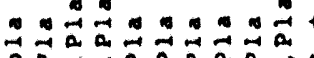
$a x+a a_{0} a n a$ तiñ

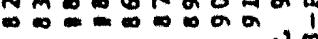

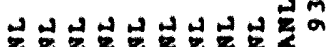

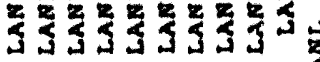

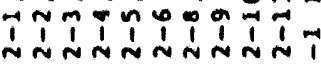

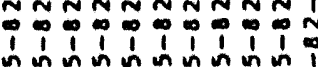

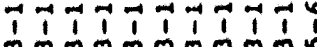
00000000000

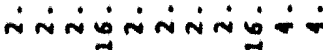
$\therefore 0000000000$

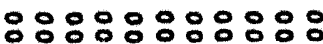

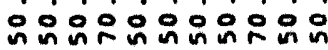

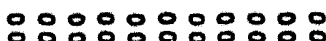

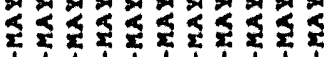

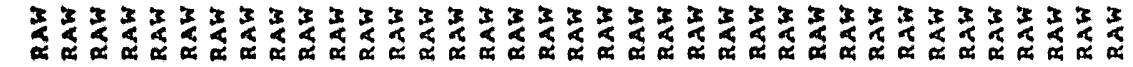

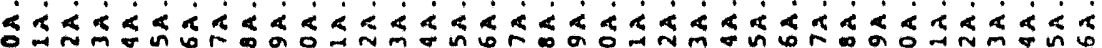

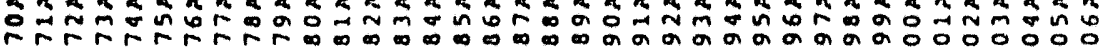
象

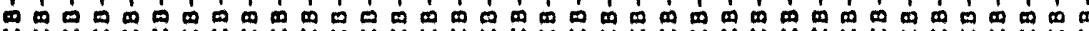

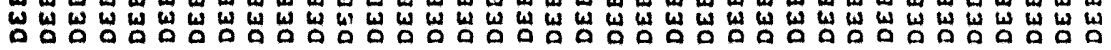

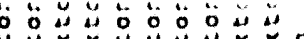

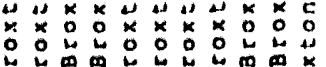

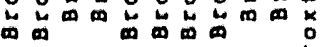

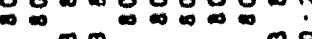
$+++++++++$

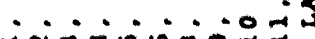

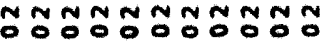

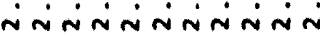

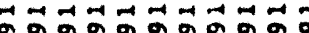
11111 1 1

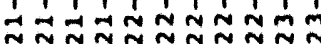

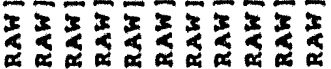

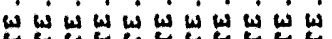

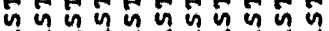

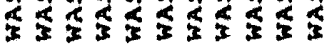
-0000000000

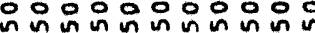

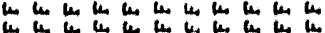

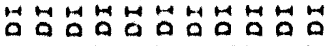

t5 c c c t

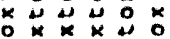

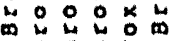
禹的占

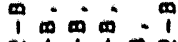

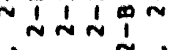
$b_{0}^{n} \dot{n} \dot{n} \dot{n} \dot{n}^{n}$ $\rightarrow+n \pi n$

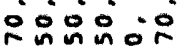

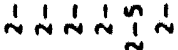
$\therefore 000.0$ NnN Nơ 용요용

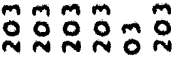

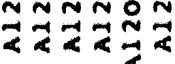
$+++t^{2}+$ -1) 0

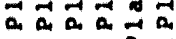
$\therefore$ inim ココさコず

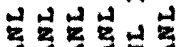
引马或哥

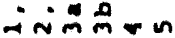

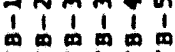

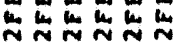
N 000000 biring

NONNONO 000000 웅영유유 웃요요요 융ㅇㅇㅇㅇㅇㅇ niñiñ

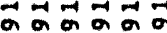
111111

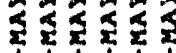

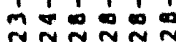

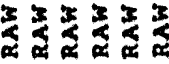
w को के के in is is in

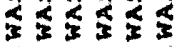
00000

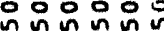

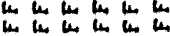

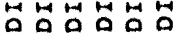

33

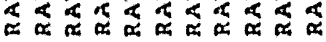
$\{<<x<<<<<<x$

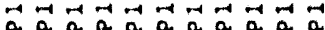
1111111111111

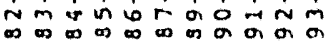

33333

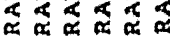

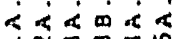

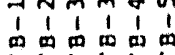

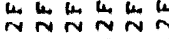

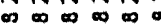




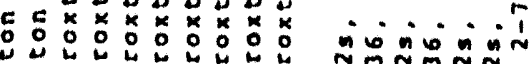

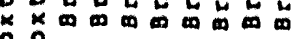

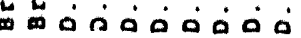

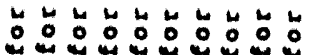

कि कि कि कि कि कि कि $1\{1919$

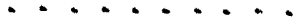

$\therefore \circ \therefore \circ \therefore \circ \therefore \circ:$

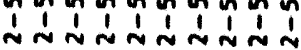

$\therefore \therefore \therefore 00 \therefore 00$

nnn nNannnn

000000̈000

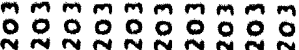

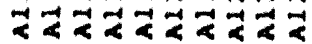

$+4++++++4$

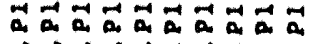

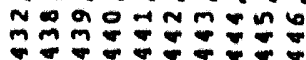

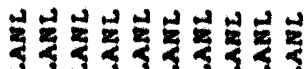

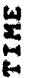

\section{0}

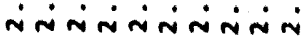

$n \min m$

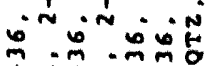

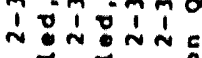

$\vec{\Delta}+\vec{*}: 0$

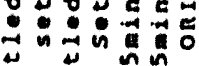

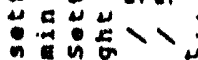

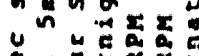

"

品

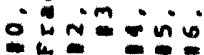

山. . U U

ư ư u

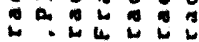

4 N w in w

$\vec{a} \vec{a} \vec{a} \vec{a} \vec{a} \vec{a}$

iñmiñ

MSTEMm

$\overrightarrow{1} \overrightarrow{1} \overrightarrow{1} \overrightarrow{1} \overrightarrow{1} \overrightarrow{1} \overrightarrow{1}$

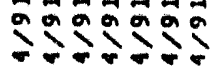

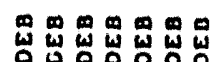

0000000

जिंतिंति

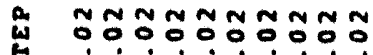

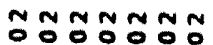

- 000000

0000000000

용요용ㅇㅇㅇ

:::::요

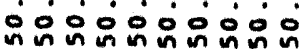

ن்

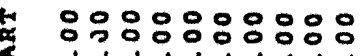

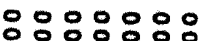

niñnininin

ininivi

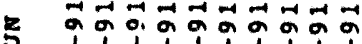

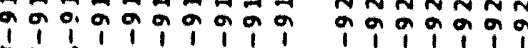

5

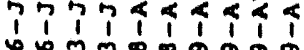

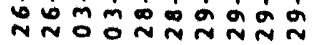

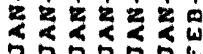

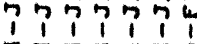

ind

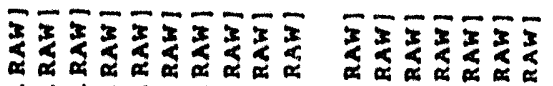

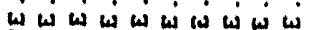

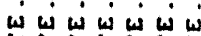

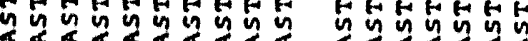

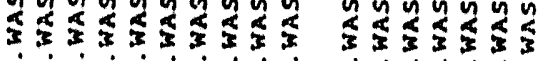

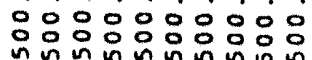

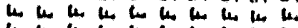

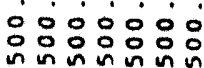

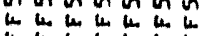

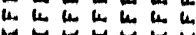

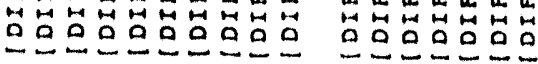

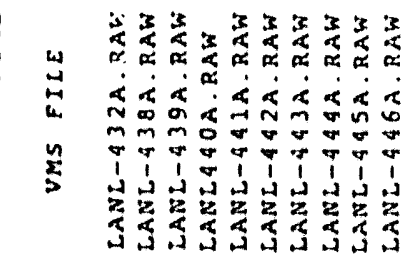

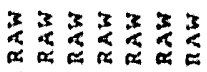

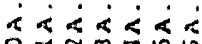

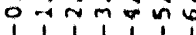

N $\alpha$ N $N$

mommon

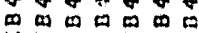

岩出出出出出出台 


$$
\text { I }
$$
0 